Rosalia Krüger de Castro

\title{
Desenvolvimento de eletrodos e substratos poliméricos flexíveis aplicados à Dispositivos \\ Fotovoltaicos Orgânicos
}

Tese de Doutorado

Tese apresentada como requisito parcial para obtenção do grau de Doutor pelo Programa de PósGraduação em Física da PUC-Rio.

Orientador: Prof. Marco Cremona 
Pontifícia Universidade Católica $_{\text {a }}$ DO RIO DE JANEIRO

Rosália Krüger de Castro

\author{
Desenvolvimento de eletrodos e substratos \\ poliméricos flexíveis aplicados à Dispositivos \\ Fotovoltaicos Orgânicos
}

Tese apresentada como requisito parcial para obtenção do grau de Doutor pelo Programa de Pós-Graduação em Física do Departamento de Física do Centro Técnico Científico da PUC-Rio. Aprovada pela Comissão Examinadora abaixo assinada.

Prof. Marco Cremona

Orientador

Departamento de Física - PUC-Rio

Prof. Marcelo Eduardo Huguenin Maia da Costa

Departamento de Física - PUC-Rio

Profa. Cecília Vilani

Departamento de Engenharia Química e de Materiais

PUC-Rio

Prof. Rogerio Valaski

INMETRO

Prof. Cleber Fabiano do Nascimento Marchiori

Uppsala University

Prof. Márcio da Silveira Carvalho

Coordenador Setorial do Centro Técnico Científico - PUC-Rio

Rio de Janeiro, 4 de maio de 2018. 
Todos os direitos reservados. É proibida a reprodução total ou parcial do trabalho sem autorização da universidade, do autor e do orientador.

\section{Rosalia Krüger de Castro}

Possui graduação em Licenciatura em Física e Mestrado em Física pela Universidade Federal de Pelotas - UFPel.

Ficha Catalográfica

de Castro, Rosalia Krüger

Desenvolvimento de eletrodos e substratos poliméricos flexíveis aplicados à Dispositivos Fotovoltaicos Orgânicos / Rosalia Krüger de Castro; orientador: Marco Cremona. - 2018.

156 f.: il. color. ; $30 \mathrm{~cm}$

Tese (Doutorado) - Pontifícia Universidade Católica do Rio de Janeiro, Departamento de Física, 2018.

Inclui referências bibliográficas.

1. Física - Tese. 2. Dispositivo Fotovoltaico Orgânico. 3.Substratos poliméricos. 4.Dispositivos flexíveis. 5.grafeno. 6. Síntese e caracterização de grafeno. I. Cremona, Marco. II. Pontifícia Universidade Católica do Rio de Janeiro. Departamento de Física. III. Título. 


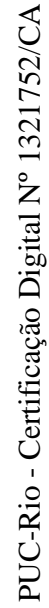

A minha família. 


\section{Agradecimentos}

Agradeço a Deus por me abençoar todos os dias com uma família linda e por me proporcionar mais esta conquista.

Agradeço ao meu filho Heitor por me ensinar a mais pura forma de amar e as minhas filhas caninas Penélope e Tinoca pelo companheirismo e carinho prestado sempre que precisei.

Agradeço ao meu colega, amigo e marido Dr. Cristol de Paiva Gouvêa por estar sempre ao meu lado, pelo incentivo, confiança e principalmente pelo amor.

Agradeço aos meus pais pelos bons princípios que me proporcionaram, pela minha educação, incentivo, carinho e amor.

Agradeço ao meu orientador Prof. Dr. Marco Cremona pela oportunidade de ser sua aluna de doutorado, por todo conhecimento trocado e apoio quando precisei.

Agradeço aos Drs. Carlos Alberto Achete e Jailton Damasceno por consentirem o desenvolvimento deste trabalho de doutorado utilizando a infraestrutura da Dimat Inmetro

Agradeço a todos os colegas da Dimat - Inmetro que de alguma forma contribuíram com a realização deste trabalho, em especial: Ao Dr. Bráulio Soares Archanjo pelo direcionamento inicial deste trabalho e pelo apoio enquanto meu chefe. A Dra. Lidia Oazem de Oliveira Costa pela oportunidade de trabalhar no seu projeto de pesquisa, pela amizade e principalmente por me mostrar que sempre podemos ser uma pessoa melhor. Ao Dr. Rogério Valaski por me ensinar e colaborar com a realização deste trabalho. A Dra. Joyce Araújo e a Dra. Aline Viero pela colaboração, incentivo e amizade. Aos colegas Bel. Carlos Alberto Senna, Dra. Clara Almeida, Dr. Benjamin Freud e Dr. Victor Caruso pelos ensinamentos de operação de equipamentos. A minha amiga e colega Dra. Alessandra Pereira por toda ajuda e apoio, principalmente na finalização deste trabalho. E por fim, aos demais colegas e amigos que muito me ajudaram com apenas um café e/ou uma conversa.

Agradeço a todos os colegas do LOEM-PUC-Rio, em especial aos Drs. Rafael dos Santos Carvalho e Harold Camargo por me auxiliarem nas atividades desenvolvidas no LOEM. 
Agradeço a CAPES e ao CNPq pelo auxílio financeiro, necessário para o desenvolvimento deste trabalho. 


\section{Resumo}

de Castro, Rosalia Krüger; Cremona, Marco (orientador). Desenvolvimento de eletrodos e substratos poliméricos flexíveis aplicados à Dispositivos Fotovoltaicos Orgânicos. Rio de Janeiro, 2018. 156p. Tese de Doutorado Departamento de Física, Pontifícia Universidade Católica do Rio de Janeiro.

Nesta tese de doutoramento apresentamos a fabricação e a caracterização de dispositivos fotovoltaicos orgânicos (OPVs) fabricados a partir de eletrodos de grafeno e de substratos híbridos flexíveis à base de polímeros recobertos com um filme fino condutor. Para isso, inicialmente sintetizamos filmes de grafeno através da técnica de deposição química em fase de vapor (CVD), seguido de modificações no processo de transferência do grafeno para o substrato desejado. Nesta etapa, desenvolvemos uma nova metodologia utilizando uma blenda condutora de EPDM-PAni que simplifica o processo de transferência e melhora as propriedades elétricas do grafeno. Em outro momento, otimizamos diferentes substratos híbridos à base de polímeros de PVC, PVA e celulose bacteriana (BC) recobertos com um filme fino condutor de ITO. Tanto os substratos híbridos flexíveis, quanto os filmes de grafeno, foram investigados por transmitância ótica e resistência de folha a fim de avaliar os seus potenciais uso para as aplicações em OPVs. Por fim, fabricamos diversas estruturas de OPVs, tanto com o grafeno como eletrodo condutor, quanto usando os substratos híbridos flexíveis. Estes dispositivos foram caracterizados principalmente através das suas curvas características $\mathrm{J} \times \mathrm{V}$, no escuro e sob iluminação. Além disso, realizamos ciclos de flexão/extensão de alguns dispositivos a fim de avaliar seu comportamento frente aos esforços mecânicos a estes submetidos. Os resultados obtidos mostraram que os filmes de grafeno fabricados são promissores para a aplicação como eletrodo condutor transparente em OPVs e que os substratos híbridos investigados podem ser utilizados em dispositivos flexíveis, visto que apresentaram comportamento semelhante aos substratos inorgânicos comumente utilizados.

\section{Palavras-chave}

Dispositivo fotovoltaico orgânico; substratos poliméricos; dispositivos flexíveis; grafeno; síntese e transferência de grafeno 


\section{Abstract}

de Castro, Rosalia Krüger; Cremona, Marco (advisor). Development of flexible electrodes and polimeric substrates applied to organic photovoltaic devices. Rio de Janeiro, 2018. 156p. Tese de Doutorado Departamento de Física, Pontifícia Universidade Católica do Rio de Janeiro.

In this doctoral thesis we present the fabrication and characterization of organic photovoltaic devices (OPVs) assembled onto graphene electrodes and flexible hybrid polymers-based substrates coated with a conductive thin film. For this, initially the graphene films were synthesized by chemical vapor deposition (CVD) technique, followed by modifications in the transfer process of the graphene to the desired substrate. In this step, we developed a new methodology using an EPDM-PAni conductive blend that simplifies the transfer process and improves the electric properties of graphene. We also used another approach which consists in optimizing different hybrid substrates based on PVC, PVA and bacterial cellulose (BC) polymers coated with an ITO conductive thin film. The flexible hybrid substrates as well as the graphene films were investigated by optical transmittance and sheet resistance in order to evaluate their potential use for OPVs applications. Finally, we fabricate various structures of OPVs, using graphene as a conducting electrode, well as using flexible hybrid substrates. Such devices were characterized mainly through their dark and light $\mathrm{J} \times \mathrm{V}$ characteristic curves. In addition, we performed flexion/extension cycles in some devices in order to evaluate their behavior against the mechanical stresses submitted to them. The results showed that the graphene films are a promising material for the application as a transparent conductive electrode in OPVs and the hybrid substrates investigated can be used in flexible devices, since they presented similar behavior to the commonly used inorganic substrates.

\section{Keywords}

Organic photovoltaic device; polymeric substrates; flexible devices; graphene; synthesis and graphene transfer 


\section{Sumário}

1 Introdução 24

$\begin{array}{ll}1.1 \text { Motivação } & 26\end{array}$

$\begin{array}{ll}\text { 1.2 Objetivo geral } & 27\end{array}$

$\begin{array}{ll}1.3 \text { Objetivos específicos } & 27\end{array}$

2 Fundamentação teórica $\quad 29$

$\begin{array}{lr}2.1 \text { Polímeros conjugados } & 29\end{array}$

2.1.1 Transporte de cargas em semicondutores orgânicos 31

2.1.2 Formação de éxcitons 34

2.2 Dispositivo fotovoltaico orgânico 35

2.2.1 Princípio de funcionamento de um dispositivo fotovoltaico orgânico 36

2.2.2 Caracterização de dispositivos fotovoltaicos orgânicos 38

2.2.3 Estruturas com heterojunções em bicamada e em volume 43

2.2.4 Breve relato da evolução dos dispositivos fotovoltaicos orgânicos $\quad 47$

2.3 Grafeno como eletrodo condutor transparente $\quad 51$

2.3.1 Estrutura do grafeno $\quad 53$

2.3.2 Propriedades óticas, eletrônicas e estruturais do grafeno 54

2.3.2.1 Transmitância ótica do grafeno $\quad 56$

2.3.2.2 Resistência de folha do grafeno $\quad 57$

2.3.2.3 Modos vibracionais do grafeno $\quad 58$

2.3.3 Métodos de síntese e produção de folhas de grafeno 63

2.3.3.1 Síntese por deposição química na fase de vapor (CVD) 64 
2.3.4 Transferência de grafeno para outros substratos

2.4 Substratos poliméricos flexíveis

2.4.1 Exemplo de comportamento mecânico e optoeletrônico desejável para aplicações em dispositivos fotovoltaicos orgânicos

3 Materiais e métodos

3.1 Crescimento dos filmes de grafeno 71

3.2 Síntese da blenda de EPDM-PAni 72

3.3 Transferência dos filmes de grafeno 75

3.3.1 Processo tradicional de transferência utilizando PMMA 76

3.4 Materiais poliméricos utilizados na fabricação dos substratos flexíveis 78

3.5 Sistema de deposição de materiais orgânicos, metálicos e óxidos 82

3.5.1 Infraestrutura para a fabricação dos dispositivos fotovoltaicos orgânicos

3.5.2 Deposição dos filmes de ITO 85

3.5.3 Deposição dos materiais orgânicos e metálicos 86

3.5.4 Materiais orgânicos utilizados na fabricação dos dispositivos $\quad 87$

3.6 Estruturas dos dispositivos fotovoltaicos orgânicos fabricados 91

3.7 Técnicas de caracterização dos materiais usados e dos dispositivos fotovoltaicos orgânicos fabricados

3.7.1 Caracterização espectroscópica

3.7.2 Caracterização elétrica 96

3.7.3 Caracterização morfológica 99

4 Resultados e discussões

4.1 Dispositivos fotovoltaicos orgânicos à base de filmes de grafeno e grafeno/EPDM-PAni usados como eletrodos condutores e transparentes 
4.1.1 Caracterização morfológica dos filmes de grafeno produzidos

4.1.2 Caracterizações elétricas e óticas dos filmes de EPDM-PAni e grafeno/EPDM-PAni

4.1.3 Processo de transferência do grafeno utilizando blenda de EPDM-PAni

4.1.4 Comparação entre os filmes de grafeno e grafeno/EPDM-PAni

4.1.5 Fabricação e caracterização dos dispositivos fotovoltaicos orgânicos à base de grafeno e grafeno/EPDM-PAni

4.2 Caracterização e fabricação de dispositivos fotovoltaicos orgânicos com os substratos poliméricos flexíveis funcionalizados

4.2.1 Otimização e deposição de ITO sobre vidro

4.2.2 Caracterização dos substratos flexíveis

4.2.3 Deposição de ITO sobre os substratos poliméricos

4.2.4 Fabricação e caracterização dos dispositivos fotovoltaicos orgânicos com substratos poliméricos flexíveis

5 Considerações finais 


\section{Lista de Figuras}

Figura 1: Curva característica de J×V do OPV baseado em PBDB-T-SF:IT-4F, com PCE da ordem de $13 \%$. Nesta mesma imagem são apresentadas as estruturas moleculares dos respectivos materiais orgânicos utilizados. [10]

Figura 2: Exemplos de polímeros conjugados e moléculas pequenas utilizados na área da eletrônica orgânica.

Figura 3: Representação esquemática de uma cadeia polimérica com (a) diferentes comprimentos de conjugação e (b) sua respectiva distribuição de energias de banda proibida. [26]

Figura 4: Distribuição gaussiana dos níveis energéticos, mostrando a formação do HOMO, LUMO e das armadilhas no interior da banda proibida. Adaptado de [28]

Figura 5: Ilustração esquemática de uma cadeia de politiofeno com presença de (a) um pólaron positivo e (b) um bipólaron positivo. [26]

Figura 6: Ilustração das possíveis formações de éxcitons em semicondutores orgânicos: (a) éxciton Frenkel e (b) éxciton de transferência de carga. Adaptado de [26]

Figura 7: Diagrama esquemático de uma estrutura típica de um dispositivo fotovoltaico orgânico, onde o substrato e o eletrodo devem ser transparentes para que a luz incidente possa atingir a camada ativa do dispositivo.

Figura 8: Ilustração esquemática do mecanismo de conversão de fótons incidentes em fotocorrente em um dispositivo fotovoltaico orgânico. [33] 
Figura 9: Curvas características $\mathrm{J} \times \mathrm{V}$ para um dispositivo fotovoltaico no escuro e sob iluminação, indicando os principais parâmetros utilizados para a sua caracterização.

Figura 10: Diagrama de níveis de energia para um dispositivo fotovoltaico cátodo/monocamada/ ânodo: (a) no escuro e (b) sob iluminação. [26, 34]

Figura 11: Espectro da radiação solar com filtro AM 0 e AM 1.5G. Adaptado de [36]

Figura 12: Estruturas em heterojunção utilizadas em dispositivos fotovoltaicos orgânicos: (a) heterojunção em bicamada e (b) heterojunção em volume.

Figura 13: Diagrama dos níveis de energia dos materiais doador e aceitador de elétrons e o processo de transferência de elétron após a dissociação do éxciton. Adaptado de [27].

Figura 14: Parâmetros de eficiência de um dispositivo fotovoltaico orgânico com diferentes espessuras do $\mathrm{C}_{60}$. A estrutura do dispositivo consiste: ITO/ CuPc (20 nm)/ C60 (X)/ BCP (7 nm)/ Ag (100 nm). Adaptado de [41].

Figura 15: (a) Diagrama esquemático da estrutura do dispositivo fotovoltaico orgânico utilizando PI como substrato flexível; (b) Curvas características de $\mathrm{J} \times \mathrm{V}$ para diferentes números de camadas de grafeno usado como anodo com diferentes dopagens; (c) Valores de $\mathrm{V}_{\mathrm{OC}}, \mathrm{J}_{\mathrm{SC}}$, FF e $\eta$ (PCE) em função dos ciclos de flexão. Adaptado de [21].

Figura 16: (a) Diagrama esquemático da estrutura do OPV utilizando PET como substrato flexível; (b) Imagem do dispositivo fotovoltaico orgânico sendo flexionado; (c) Curvas características de $\mathrm{J} \times \mathrm{V}$ para diferentes números de camadas de grafeno usado como anodo. Adaptado de [22].

Figura 17: (a) Transmitância ótica de uma a quatro camadas de grafeno sobre substratos de quartzo. Inserido na figura um gráfico da transmitância ótica antes e depois da dopagem do grafeno com ácido nítrico $\left(\mathrm{HNO}_{3}\right)$. (b) Resistência de folha em função do número de camadas de grafeno transferido pelo método roll-to-roll 
com e sem dopagem com $\mathrm{HNO}_{3}$ e pelo método tradicional usando PMMA. Adaptado de [24]

Figura 18: Estrutura cristalina do grafeno destacando a configuração dos seus orbitais eletrônicos responsáveis pela hibridização $\mathrm{sp}^{2}$. Adaptado de [49]

Figura 19: (a) Curva tridimensional da dispersão de energia para os elétrons $\pi$ e $\pi^{*}$ do grafeno, via método tight-binding. A direita um aumento do comportamento linear da dispersão próximo ao ponto de Dirac. (b) Rede hexagonal do grafeno no espaço recíproco mostrando os pontos de alta simetria $\Gamma, \mathrm{M}, \mathrm{K}$ e K'. [50]

Figura 20: Transmitância ótica de uma monocamada de grafeno obtida pelo método de esfoliação mecânica. Inserido nesta figura, também se apresenta o gráfico da transmitância ótica em função do número de camadas de grafeno. Adaptado de [51].

Figura 21: Esquema ilustrativo dos possíveis espalhamentos da luz com o material: elástico (Rayleigh) e inelástico (Raman).

Figura 22: Diagrama de dispersão de fônons para o grafeno, calculado para as direções de alta simetria $\Gamma$, M e K. Adaptado de [52]

Figura 23: Espectro Raman típico de uma amostra de grafeno indicando os principais modos vibracionais presentes (bandas G, D, D' e G') com energia de excitação do laser de 2,41 eV (514 nm). Adaptado de [53]

Figura 24: Principais processos Raman que ocorrem no grafeno: (a) de primeira ordem que dá origem à banda G; (b) e (c) de segunda ordem com um fônon dando origem à banda D (inter-vales) em (b) e à banda D' (intra-vales) em (c); (d) de segunda ordem com dois fônons dando origem à banda $\mathrm{G}^{\prime}$; (e) possível tripla ressonância dando origem à banda $\mathrm{G}^{\prime}$. [53]

Figura 25: Espectros Raman mostrando a evolução da banda G' para uma (1L), duas (2L) e aproximadamente três (3L) camadas de grafeno para excitações de 532nm. Adaptado de [55] 
Figura 26: Diagrama de fase binário do cobre e do carbono. Em destaque na figura, a temperatura e a concentração de carbono de interesse para o crescimento de grafeno. Adaptado de [60]

Figura 27: Estrutura de fabricação do dispositivo fotovoltaico orgânico, destacando as diferentes camadas e suas respectivas espessuras. Adaptado de [65]

Figura 28: Diagrama esquemático do aparato usado para aplicar testes de compressão e extensão no dispositivo fotovoltaico orgânico, sendo (a) o momento de extensão e (b) de compressão; (c) Variação da morfologia do OPV depois da compressão em 30 e 50\% de sua área. Adaptado de [65]

Figura 29: Medidas de $\mathrm{V}_{\mathrm{OC}}, \mathrm{J}_{\mathrm{SC}}$, FF e PCE em relação a quantidade de ciclos de compressão e extensão aplicado ao dispositivo. Adaptado de [65]

Figura 30: (a) Representação esquemática da instalação do sistema de deposição por CVD. (b) Sistema de deposição utilizado.

Figura 31: Estrutura polimérica do EPDM formado a partir dos monômeros de etileno, propileno e dieno. Adaptado de [67]

Figura 32: Estrutura polimérica da PAni. [69]

Figura 33: Ilustração do processo de síntese da blenda de EPDM-PAni.

Figura 34: Imagens do processo de transferência dos filmes de grafeno: (a) cobre com o filme de grafeno/PMMA flutuando na solução de $\mathrm{FeCl}_{3}$; (b) Grafeno/PMMA em água deionizada após a corrosão total do cobre; (c) Substrato de vidro apanhando o filme de grafeno/PMMA; (d) Imagem do grafeno/PMMA sobre o substrato de vidro.

Figura 35: (a) Estrutura química do polietileno tereftalato (PET); (b) Espectro de transmitância ótica obtida em vidro (glass), PET e com ânodo de $\mathrm{MoO}_{3} / \mathrm{Ag}$. Adaptado de [70].

Figura 36: Espectro de transmitância ótica obtida a partir de um substrato de BC recoberto com $185 \mathrm{~nm}$ de ITO. Adaptado de [73]. 
Figura 37: Estrutura química do monômero e do seu respectivo polímero, o poliacetato de vinila.

Figura 38: Estrutura química do monômero e do seu respectivo polímero, o policloreto de vinila.

Figura 39: Estrutura química da BC, tanto para celulose natural, quanto sintetizada.

Figura 40: (a) Imagem do OLED utilizado para fototerapia dinâmica. b) Aparelho portátil completo para realização do tratamento. [80]

Figura 41: Sistema de deposição de filmes finos do Laboratório de Dispositivos Orgânicos (Lador) da Dimat/Inmetro.

Figura 42: Sistema de deposição de filmes finos do Laboratório de Opto Eletrônica Molecular (LOEM) da PUC-Rio.

Figura 43: Estrutura quimica do CuPc.

Figura 44: (a) Curvas características tipo $\mathrm{J} \times \mathrm{V}$ obtidas de um dispositivo bicamada formado por $\operatorname{CuPc}(15 \mathrm{~nm}) / \mathrm{C}_{60}(40 \mathrm{~nm})$ e de um tricamada formado por $\mathrm{CuPc}(15$ $\mathrm{nm}) / \mathrm{SnPc}(16 \mathrm{~nm}) / \mathrm{C} 60$ (40 nm), nas condições de escuro (dark) e sob $100 \mathrm{~mW} / \mathrm{cm}^{2}$ (1 sun); (b) Dependência da tensão de circuito aberto (Voc), do fator de preenchimento $(\mathrm{FF})$ e da densidade de corrente de curto-circuito $\left(\mathrm{J}_{\mathrm{sc}}\right)$ em relação à espessura do filme de $\mathrm{SnPc}$ na estrutura ITO/CuPc $(15 \mathrm{~nm}) / \mathrm{SnPc}\left(\mathrm{t}_{\mathrm{SnPc}}\right) / \mathrm{C}_{60}(40$ $\mathrm{nm}) / \mathrm{BCP} / \mathrm{Ag}$. [83]

Figura 45: Estrutura química do fulereno $\mathrm{C}_{60}$.

Figura 46: Estrutura química do $\mathrm{Alq}_{3}$ formado por três ligantes de hidroxiquinolina.

Figura 47: Estrutura química do TPBI.

Figura 48: Estrutura física e níveis energéticos do dispositivo fotovoltaico orgânico à base de grafeno, com estrutura tipo Vidro/ eletrodo/ $\mathrm{CuPc}(30 \mathrm{~nm}) / \mathrm{C}_{60}(60 \mathrm{~nm}) /$ $\mathrm{Alq}_{3}(10 \mathrm{~nm}) / \mathrm{Ca}(25 \mathrm{~nm}) / \mathrm{Al}(75 \mathrm{~nm})$ 
Figura 49: Níveis energéticos dos dispositivos fotovoltaicos orgânicos descrito anteriormente.

Figura 50: Níveis energéticos dos dispositivos fotovoltaicos orgânicos descrito anteriormente

Figura 51: Montagem experimental do método de quatro pontas, utilizada para medir a resistência de folha do grafeno sobre $\mathrm{SiO}_{2}$, utilizando contatos de ouro.

Figura 52: Esquematização do ciclo de flexão e extensão do dispositivo fotovoltaico orgânico com substrato polimérico, flexionado sob diferentes diâmetros e caracterizada a cada 10 ciclos realizados.

Figura 53: Ilustração do processo de medição da rugosidade de uma determinada superfície, destacando a rugosidade média aritmética (Mean Line). Adaptado de [89].

Figura 54: Dispositivos fotovoltaicos orgânicos fabricados sobre um substrato de PVA, destacando sua flexibilidade mecânica.

Figura 55: (a) Imagem de microscopia ótica de grafeno sobre $\mathrm{Si} / \mathrm{SiO}_{2}$ mostrando as falhas, os resíduos de PMMA e as regiões de onde foram obtidos os espectros Raman; (b) Espectros Raman das posições marcadas na imagem ótica.

Figura 56: Resistência de folha da blenda de EPDM-PAni em função de diferentes quantidades de PAni, em peso.

Figura 57: Medidas de UV-Vis da blenda de EPDM-PAni com diferentes porcentagens em massa de PAni (5-50 wt\%).

Figura 58: Relação entre condutância de folha $\left(\mathrm{RS}_{\mathrm{S}}^{-1}\right)$ e transmitância ótica em relação à concentração de PAni em EPDM.

Figura 59: (a) Imagem obtida por microscopia ótica identificando duas distintas fases, as quais compões a blenda de EPDM-PAni. (b) e (c) Espectros Raman coletados separadamente nas regiões identificadas na imagem ótica. 
Figura 60: Esquematização do processo de transferência: (a) Síntese da solução de EPDM-PAni; (b) Deposição por centrifugação de solução de EPDM-PAni sobre a folha de grafeno/ $\mathrm{Cu}$, seguido da corrosão do $\mathrm{Cu}$ através da solução de $\mathrm{FeCl}_{3} \mathrm{e}$ transferência para o substrato final (vidro ou polímero flexível); (c) Imagens do grafeno/EPDM-PAni flutuando em água (imagens i e ii) e depois, transferidas para um substrato flexível de policloreto de vinila (PVC) (imagens iii e iv).

Figura 61: Comparação entre os espectros Raman obtidos em filme de grafeno transferido com PMMA e em filme de grafeno/EPDM-PAni;

Figura 62: Comparação entre as posições dos modos vibracionais $\mathrm{G}$ e G' obtidos em duas posições da amostra de grafeno/EPDM-PAni.

Figura 63: Espectros de FTIR obtidos em filmes de grafeno/EPDM-PAni, EPDM e PAni.

Figura 64: Estruturas químicas do EPDM-PAni, do grafeno e representação do mecanismo de dopagem.

Figura 65: Densidade de corrente versus tensão $(\mathrm{J} \times \mathrm{V})$ dos Dispositivos fotovoltaicos orgânicos com estruturas tipo vidro/eletrodo/ $\mathrm{CuPc} / \mathrm{C}_{60} / \mathrm{Alq}_{3} / \mathrm{Ca} / \mathrm{Al}$, com e sem iluminação, utilizando os seguintes eletrodos: (a) ITO comercial, (b) grafeno e (c) grafeno/EPDM-PAni (blenda).

Figura 66: Medidas de UV-Vis dos substratos de BC e da BC modificada com PVC.

Figura 67: Medida de FTIR da matéria prima utilizada para fabricar os substratos de PVC.

Figura 68: Medidas de UV-Vis dos substratos de vidro, BC, PVC e PVA, e das mesmas com deposição de filme fino de ITO.

Figura 69: Evolução temporal do comportamento da resistência de folha dos filmes finos de ITO depositado sobre os substratos de vidro, PVA, PVC e BC. 
Figura 70: Variação da massa dos substratos poliméricos com ITO depositado em função do tempo. A barra de erro apresentada tem origem no desvio padrão obtido a partir da média das cinco medidas realizadas em cada ponto.

Figura 71: Curvas características de densidade de corrente versus tensão aplicada $(\mathrm{J} \times \mathrm{V})$ aos dispositivos com estrutura tipo substrato/eletrodo/ $\mathrm{CuPc} / \mathrm{C}_{60} / \mathrm{Alq}_{3} / \mathrm{Ca} / \mathrm{Al}$ com os seguintes substratos/eletrodo: (a) Vidro/ITO (comercial); (b) Vidro/ITO; (c) PVA/ITO; (d) BC/ITO; (e) PVC/ITO.

Figura 72: Curvas características de densidade de corrente versus tensão aplicada $(\mathrm{J} \times \mathrm{V})$ aos dispositivos com estrutura tipo substrato/eletrodo/ $\mathrm{MoO}_{3} / \mathrm{CuPc}: \mathrm{C}_{60} /$ TPBI/ Al, com os seguintes substratos/eletrodo: (a) Vidro/ITO (comercial); (b) Vidro/ITO; (c) PVA/ITO; (d) BC/ITO; (e) PVC//ITO.

Figura 73: Curvas características de densidade de corrente versus tensão aplicada $(\mathrm{J} \times \mathrm{V})$ aos dispositivos com estrutura tipo substrato/eletrodo/ $/ \mathrm{MoO}_{3} / \mathrm{CuPc} / \mathrm{C}_{60} /$ TPBI/ Al, com os seguintes substratos/eletrodo: (a) Vidro/ITO; (b) PVA/ITO; (c) BC/ITO; (d) PVC/ITO.

Figura 74: Curvas características de densidade de corrente versus tensão aplicada $(\mathrm{J} \times \mathrm{V})$ aos dispositivos com estrutura tipo substrato/eletrodo/CuPc $(15 \mathrm{~nm}) / \mathrm{SnPc}$ $(15 \mathrm{~nm}) / \mathrm{C}_{60}(40 \mathrm{~nm}) / \mathrm{Al}(100 \mathrm{~nm})$, com os seguintes substratos/eletrodo: (a) Vidro/ITO comercial; (b) Vidro/ITO; (c) PVA/ITO; (d) BC/ITO.

Figura 75: Curvas características de densidade de corrente versus tensão aplicada $(\mathrm{J} \times \mathrm{V})$ aos dispositivos com estrutura tipo vidro/ITO comercial/ $\mathrm{MoO}_{3}(5 \mathrm{~nm}) /$ camada ativa $(70 \mathrm{~nm}) /$ TPBI $(10 \mathrm{~nm}) / \mathrm{Al}(100 \mathrm{~nm})$ com camada ativa em

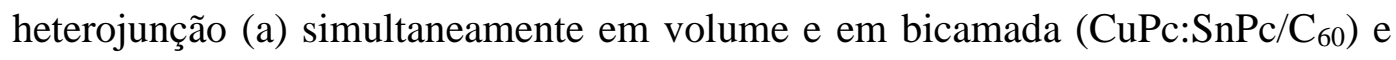
(b) em tricamada $\left(\mathrm{CuPc} / \mathrm{SnPc} / \mathrm{C}_{60}\right)$.

Figura 76: Curvas características de densidade de corrente versus tensão aplicada $(\mathrm{J} \times \mathrm{V})$ aos dispositivos com estrutura tipo substrato/ITO/ $\mathrm{MoO}_{3}(5 \mathrm{~nm}) / \mathrm{CuPc}(15$ $\mathrm{nm}) / \mathrm{SnPc}(15 \mathrm{~nm}) / \mathrm{C}_{60}(40 \mathrm{~nm}) / \mathrm{TPBI}(10 \mathrm{~nm}) / \mathrm{Al}(100 \mathrm{~nm})$, com os seguintes substratos: (a) Vidro e (b) BC.

Figura 77: Imagem mostrando o teste de flexão realizado em um dispositivo fotovoltaico orgânico com substrato polimérico de BC: (a) Na posição 1 com 30 
mm de diâmetro; (b) Na posição 2 com $25 \mathrm{~mm}$ de diâmetro; (c) Na posição $3 \mathrm{com}$ 20 mm de diâmetro; e (d) Na posição 4 com 15 mm de diâmetro.

Figura 78: Densidade de corrente versus tensão $(\mathrm{J} \times \mathrm{V})$ das curvas do dispositivo com estrutura $\mathrm{BC} / \mathrm{ITO} / \mathrm{MoO}_{3} / \mathrm{CuPc} / \mathrm{SnPc} / \mathrm{C}_{60} / \mathrm{TPBI} / \mathrm{Al}$ submetido a diferentes diâmetros de flexão $(15,20,25$ e $30 \mathrm{~mm})$.

Figura 79: Densidade de corrente versus tensão $(\mathrm{J} \times \mathrm{V})$ das curvas do dispositivo com estrutura $\mathrm{BC} / \mathrm{ITO} / \mathrm{MoO}_{3} / \mathrm{CuPc} / \mathrm{SnPc} / \mathrm{C}_{60} / \mathrm{TPBI} / \mathrm{Al}$ submetido a 10 ciclos em cada diâmetro de flexão (15, 20, 25 e 30 mm).

Figura 80: Densidade de corrente versus tensão $(\mathrm{J} \times \mathrm{V})$ das curvas do dispositivo com estrutura $\mathrm{BC} / \mathrm{ITO} / \mathrm{MoO}_{3} / \mathrm{CuPc} / \mathrm{SnPc} / \mathrm{C}_{60} / \mathrm{TPBI} / \mathrm{Al}$ : (a) após 2 dias sem flexão e com 10 ciclos de flexão na posição 4 do cilindro com $15 \mathrm{~nm}$ de diâmetro; e (b) após 5 dias sem flexão de flexão.

Figura 81: Visão geral dos dispositivos fotovoltaicos orgânicos fabricados e sua respectiva eficiência (PCE). 


\section{Lista de tabelas}

Tabela 1: Principais parâmetros de caracterização de dispositivos fotovoltaicos orgânicos para distintas camadas ativas empregadas na estrutura $\mathrm{ITO} / \mathrm{ZnO} /$ camada ativa/ $\mathrm{MoO}_{3} / \mathrm{Al}$. Adaptado de [10]

Tabela 2: Resumo de alguns trabalhos que descrevem o uso do grafeno como eletrodo condutor e transparente aplicado aos dispositivos fotovoltaicos orgânicos.

Tabela 3: Valores das razões $\mathrm{I}_{\mathrm{D}} / \mathrm{I}_{\mathrm{G}}$ e $\mathrm{I}_{\mathrm{G}} / \mathrm{I}_{\mathrm{G}}$ e, a FWHM da banda G' para os espectros Raman mostrados na Figura 55 (b).

Tabela 4: Relação entre os valores de $\mathrm{R}_{\mathrm{S}}, \mathrm{R}_{\mathrm{A}}$ e $\mathrm{T}$ obtidos para diferentes porosidades utilizadas no processo de filtragem da solução de EPDM-PAni.

Tabela 5: Comparação entre os principais parâmetros que afetam os dispositivos fotovoltaicos.

Tabela 6: Sumário com os principais parâmetros obtidos das curvas $\mathrm{J} \times \mathrm{V}$ dos dispositivos com estrutura Substrato/eletrodo/ $\mathrm{CuPc} / \mathrm{C}_{60} / \mathrm{Alq}_{3} / \mathrm{Ca} / \mathrm{Al}$, mostradas na Figura 65 e o respectivo valor de resistência de folha $\left(\mathrm{R}_{\mathrm{S}}\right)$.

Tabela 7: Parâmetros utilizados para a deposição dos filmes de ITO sobre vidro e seus respectivos valores de resistências de folha.

Tabela 8: Parâmetros utilizados para a deposição dos filmes de ITO sobre vidro e seus respectivos valores de resistências de folha.

Tabela 9: Parâmetros com a melhor condição de deposição dos filmes de ITO sobre vidro.

Tabela 10: Valores de resistência de folha e de transmitância ótica em $550 \mathrm{~nm}$ para os distintos substratos estudados com ITO depositado e a variação percentual da propriedade em relação ao substrato de vidro/ITO. 
Tabela 11: Sumário com os principais parâmetros obtidos a partir das curvas $\mathrm{J} \times \mathrm{V}$ dos dispositivos com estrutura substrato/eletrodo/ $\mathrm{CuPc} / \mathrm{C}_{60} / \mathrm{Alq}_{3} / \mathrm{Ca} / \mathrm{Al}$, mostradas na Figura 71.

Tabela 12: Sumário com os principais parâmetros obtidos a partir das curvas $J \times V$ dos dispositivos com estrutura substrato/eletrodo/ $\mathrm{MoO}_{3} / \mathrm{CuPc}: \mathrm{C}_{60} / \mathrm{TPBI} / \mathrm{Al}$, mostradas na Figura 72.

Tabela 13: Sumário com os principais parâmetros obtidos a partir das curvas $J \times V$ dos dispositivos com estrutura substrato/eletrodo/ $\mathrm{MoO}_{3} / \mathrm{CuPc} / \mathrm{C}_{60} / \mathrm{TPBI} / \mathrm{Al}$, mostradas na Figura 73.

Tabela 14: Sumário com os principais parâmetros obtidos a partir das curvas $J \times V$ dos dispositivos com estrutura substrato/eletrodo/CuPc/SnPc/ $\mathrm{C}_{60} / \mathrm{Al}$, mostradas na Figura 74.

Tabela 15: Sumário com os principais parâmetros obtidos a partir das curvas $J \times V$ dos dispositivos com estrutura vidro/ITO comercial/ $\mathrm{MoO}_{3} /$ camada ativa/TPBI/Al, mostradas na Figura 75.

Tabela 16: Sumário com os principais parâmetros obtidos a partir das curvas $\mathrm{J} \times \mathrm{V}$ dos dispositivos com estrutura substrato/eletrodo/ $\mathrm{MoO}_{3} / \mathrm{CuPc} / \mathrm{SnPc} / \mathrm{C}_{60} / \mathrm{TPBI} / \mathrm{Al}$, mostradas nas Figuras 75 (b) e 76.

Tabela 17: Sumário com os principais parâmetros obtidos das curvas $\mathrm{J} \times \mathrm{V}$ do dispositivo com estrutura $\mathrm{BC} / \mathrm{ITO} / \mathrm{MoO}_{3} / \mathrm{CuPc} / \mathrm{SnPc} / \mathrm{C}_{60} / \mathrm{TPBI} / \mathrm{Al}$ mostrada na Figura 78, para as diferentes posições de flexão.

Tabela 18: Sumário com os principais parâmetros obtidos das curvas $\mathrm{J} \times \mathrm{V}$ do dispositivo com estrutura $\mathrm{BC} / \mathrm{ITO} / \mathrm{MoO}_{3} / \mathrm{CuPc} / \mathrm{SnPc} / \mathrm{C}_{60} / \mathrm{TPBI} / \mathrm{Al}$ mostrada na Figura 79, com 10 ciclos de flexão para as diferentes posições.

Tabela 19: Sumário com os principais parâmetros obtidos das curvas $\mathrm{J} \times \mathrm{V}$ do dispositivo com estrutura $\mathrm{BC} / \mathrm{ITO} / \mathrm{MoO}_{3} / \mathrm{CuPc} / \mathrm{SnPc} / \mathrm{C}_{60} / \mathrm{TPBI} / \mathrm{Al}$ mostradas nas Figuras 79 e 80, após 0, 2 e 5 dias sem e com ciclos de flexão com diâmetro de $15 \mathrm{~mm}$. 


\section{Lista de equações}

$\begin{array}{ll}\text { Equação } 1 & 40\end{array}$

Equação 2

Equação 3

Equação 4

Equação 5

$\begin{array}{ll}\text { Equação } 6 & 43\end{array}$

$\begin{array}{ll}\text { Equação } 7 & 43\end{array}$

Equação 8

Equação 9

Equação $10 \quad 56$

$\begin{array}{ll}\text { Equação } 11 & 56\end{array}$

$\begin{array}{ll}\text { Equação } 12 & 57\end{array}$

$\begin{array}{ll}\text { Equação } 13 & 58\end{array}$

Equação 14

$\begin{array}{ll}\text { Equação } 15 & 95\end{array}$

$\begin{array}{ll}\text { Equação } 16 & 95\end{array}$

Equação $17 \quad 97$

$\begin{array}{ll}\text { Equação } 18 & 97\end{array}$ 
Equação 19

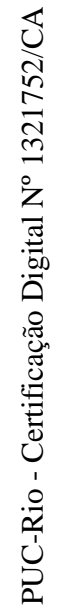




\section{1 Introdução}

A Eletrônica Orgânica tem atraído forte atenção nos últimos anos, devido às vantagens de flexibilidade mecânica, fina espessura, processo de fabricação simples e principalmente pelo baixo consumo energético, oferecendo benefícios significativos sobre a tecnologia desenvolvida com materiais inorgânicos, tal como o silício, também chamada de eletrônica convencional [1]. Este avanço tecnológico começou em 1976 quando H. Shirakawa, A.G. MacDiarmid e A. J. Heeger descobriram que o polímero poliacetileno apresenta um aumento em sua condutividade elétrica ao ser dopado com iodo. Esta descoberta resultou na atribuição do Prêmio Nobel em química no ano de 2000, destacando a importância desta área para o avanço da tecnologia.

$\mathrm{Na}$ sequência, os primeiros dispositivos optoeletrônicos orgânicos foram desenvolvidos por C. W. Tang e S. A. VanSlyke, entre os anos de 1986 e 1987, no caso uma célula fotovoltaica orgânica [2] e um diodo orgânico emissor de luz [3]. Desde então a melhoria da eficiência, da estabilidade e da redução do custo de produção têm sido alvos de intensa investigação e ainda são requisitos obrigatórios para a aplicação prática dos mais distintos dispositivos orgânicos, sendo os mais conhecidos os dispositivos fotovoltaicos (OPV, do inglês Organic Photovoltaic) [4, 5] e os diodos emissores de luz (OLED, do inglês Organic Light Emitting Diode) [6-8].

$\mathrm{Na}$ grande área da Eletrônica Orgânica, os dispositivos fotovoltaicos orgânicos merecem destaque por permitir a conversão da luz solar diretamente em energia elétrica e, portanto, sendo considerados como promissoras fontes de energia renovável, o que poderá representar uma possível alternativa aos sistemas fotovoltaicos convencionais, à base de telureto de cádmio (CdTe), arseneto de gálio (GaAs) e antimoneto de gálio (GaSb), os quais já atingiram eficiências de conversão de potência de $42 \%$ em 2017. [9]

Ainda neste mesmo ano, devido a intensas pesquisas, a classe dos dispositivos fotovoltaicos orgânicos atingiu um novo recorde de eficiência de conversão de potência (PCE - do inglês Power Conversion Efficiency). Um grupo de pesquisadores chineses desenvolveu uma célula solar orgânica baseada em um novo polímero doador (IT-4F) e em uma molécula aceitadora de elétrons (PBDB-T-SF). A Figura 1 ilustra as estruturas 
moleculares destes dois novos materiais, bem como a curva de densidade de corrente elétrica em relação à tensão aplicada ao dispositivo, resultando numa eficiência de conversão de potência de 13\%. [10] Maiores detalhes sobre estes dispositivos serão discutidos durante a fundamentação teórica desta tese.

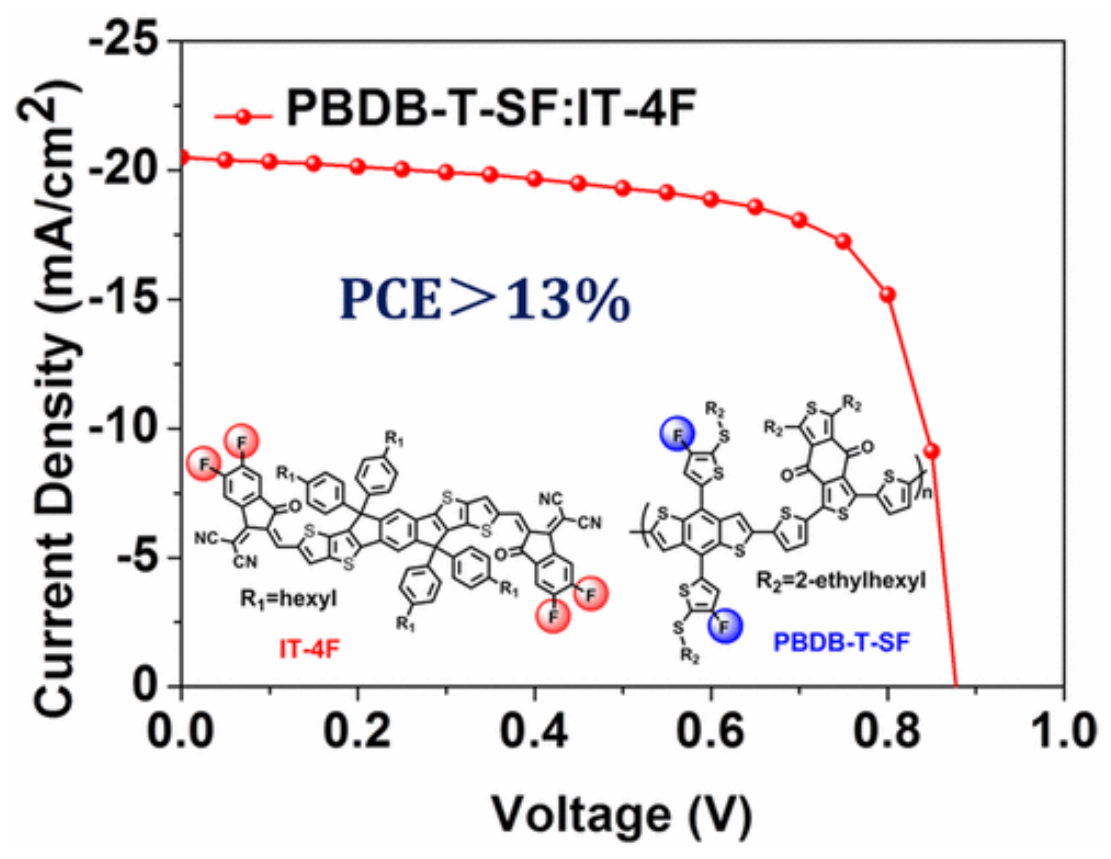

Figura 1: Curva característica de J×V do OPV baseado em PBDB-T-SF:IT-4F, com PCE da ordem de $13 \%$. Nesta mesma imagem são apresentadas as estruturas moleculares dos respectivos materiais orgânicos utilizados. [10]

Paralelamente à pesquisa realizada pelo grupo chinês, a empresa alemã Heliatek ${ }^{\circledR}$ divulgou em seu site (http://www.heliatek.com) que a sua equipe de P\&D desenvolveu um dispositivo com eficiência de conversão de potência de $13,2 \%$, estabelecendo um novo recorde mundial para a conversão direta da luz solar em eletricidade usando dispositivos fotovoltaicos orgânicos. Segundo a mesma empresa, este recorde foi confirmado por medições independentes realizadas pelo Fraunhofer Institute.

Mesmo diante das diversas vantagens dos dispositivos fotovoltaicos orgânicos em relação aos inorgânicos, é necessário que os primeiros alcancem níveis de eficiência de conversão de potência comparados aos dispositivos inorgânicos convencionais, em conjunto com a flexibilidade mecânica e durabilidade (tempo de vida). Para isso, a área da Eletrônica Orgânica deve ainda recorrer a uma intensa pesquisa e desenvolvimento no que diz respeito à diversos fatores, tais como a durabilidade e resistência às flexões 
mecânicas, bem como a pela possibilidade de utilizar novos substratos flexíveis, entre outros.

Diante disso, é importante destacar que a pesquisa realizada neste projeto se encaixa nestas direções e pretende contribuir para o avanço da aplicação da Eletrônica Orgânica na sociedade. Este trabalho de doutorado ocorreu de forma cooperativa entre duas distintas instituições: a Divisão de Metrologia de Materiais (Dimat) do Inmetro e o Laboratório de Optoeletrônica Molecular (LOEM) do Departamento de Física da PUCRio, aproveitando de ambos os grupos seus respectivos conhecimentos e experiências em diferentes áreas, unificando os resultados neste trabalho.

Dentre as atividades realizadas destacamos a síntese e uso de grafeno como eletrodo condutor e transparente, a otimização de substratos poliméricos híbridos e suas aplicações como substratos condutores e transparentes, tudo isso aplicado na fabricação de dispositivos fotovoltaicos orgânicos, conforme será descrito ao longo desta tese.

\section{1 Motivação}

$\mathrm{Na}$ área da Eletrônica Orgânica, um dos aspectos fundamentais para a maioria dos dispositivos é a necessidade de um dos eletrodos ser condutor e transparente. Hoje em dia os óxidos condutores transparentes são amplamente utilizados como eletrodos em uma série de dispositivos, tanto na eletrônica convencional, quanto na orgânica. No entanto, com o aumento da demanda por matérias primas - especialmente do elemento índio (In) - aumentou-se também a procura de alternativas para o óxido de índio e estanho (ITO, do inglês indium tin oxide) $[11,12]$. Além do fato do ITO possuir limitações devido ao seu custo de produção e escassez de matéria prima, este é sensível a ambientes corrosivos, relativamente frágil à flexão mecânica, impondo limitações em diversas aplicações.

Diante deste cenário, filmes de grafeno e substratos poliméricos têm sido propostos como a nova geração de eletrodo condutor transparente e substratos flexíveis, respectivamente, para aplicação em dispositivos fotovoltaicos orgânicos.

O grafeno é considerado um material promissor devido ao seu baixo custo de produção, alta transparência, elevada condutividade elétrica, resistência química e alta estabilidade à flexão mecânica, em oposição ao ITO. Neste contexto, resultados promissores têm sido alcançados em dispositivos fotovoltaicos orgânicos substituindo o ITO por grafeno em eletrodos condutores transparentes [13-23]. 
No entanto, por ser uma tecnologia recente, ainda existem fatores importantes que precisam ser investigados sobre o uso do grafeno. Fazem-se necessárias técnicas para facilitar a sua manipulação e sua aplicabilidade, como por exemplo, uma síntese de alta qualidade, sua transferência livre de resíduos para outros substratos e uma dopagem estável promovendo uma otimização de suas propriedades físico-químicas. [24, 25].

Aspectos semelhantes são discutidos acerca dos substratos poliméricos flexíveis, os quais necessitam ser funcionalizados para serem utilizados em dispositivos orgânicos flexíveis. Dentre estas melhorias destacam-se a otimização da sua transparência em conjunto com a deposição de um material condutor para atuar como eletrodo no dispositivo, resultando em um substrato híbrido, condutor e flexível.

\section{2}

\section{Objetivo geral}

O objetivo geral deste trabalho foi fabricar, caracterizar e implementar a utilização de substratos condutores, transparentes e flexíveis em dispositivos fotovoltaicos orgânicos. Para isso, foram utilizados tanto filmes de grafeno produzidos por CVD, quanto substratos poliméricos híbridos (polímero recoberto com óxido condutor), em substituição aos substratos e eletrodos convencionais.

\section{3}

\section{Objetivos específicos}

Para alcançar o objetivo geral deste trabalho, este foi dividido em algumas etapas a fim de facilitar sua evolução, desenvolvimento e interpretação dos resultados. Essas etapas são:

- Implantar o funcionamento do sistema de CVD (localizado no Inmetro) e melhorar a sua infraestrutura de acordo com as necessidades de fabricação dos filmes finos produzidos;

- Crescer filmes de grafeno através da técnica CVD, para serem utilizados como eletrodo em dispositivos fotovoltaicos orgânicos, bem como explorar as técnicas de transferência do filme produzido ao substrato desejado;

- Caracterizar as propriedades eletrônicas, morfológicas, ópticas e estruturais dos filmes de grafeno produzidos; 
- Funcionalizar os substratos poliméricos para serem utilizados como substratos flexíveis, transparentes e condutores em dispositivos fotovoltaicos orgânicos;

- Fabricar dispositivos fotovoltaicos orgânicos utilizando filmes de grafeno e substratos poliméricos híbridos como eletrodos e substratos flexíveis;

- Caracterizar os dispositivos fotovoltaicos orgânicos fabricados, principalmente através das curvas características $\mathrm{J} \times \mathrm{V}$ e correlacionar as melhores estruturas fabricadas com os resultados obtidos.

No Capítulo 2 uma introdução geral sobre os polímeros conjugados e seu uso em dispositivos fotovoltaicos orgânicos é apresentada. Na sequência, são apresentados o princípio de funcionamento, a caracterização, as possíveis estruturas em heterojunção e um breve relato da evolução dos dispositivos fotovoltaicos orgânicos. Ainda neste capítulo, é apresentado o grafeno como uma alternativa para aplicações como eletrodo condutor transparente em dispositivos fotovoltaicos orgânicos, bem como a sua estrutura, principais propriedades e produção. Por fim, uma breve revisão sobre as principais propriedades que um substrato deve apresentar para ser aplicado em dispositivos e os materiais rígidos e flexíveis que hoje são utilizados para este fim são apresentados.

No Capítulo 3 são discutidos os materiais e métodos utilizados nesta tese. Este tópico contempla a descrição das sínteses realizadas, da instrumentação utilizada e das técnicas experimentais empregadas no processo de caracterização dos filmes, dos substratos poliméricos e dos dispositivos fotovoltaicos orgânicos fabricados.

No Capítulo 4 são apresentados os resultados e discussões obtidos a partir do desempenho dos filmes de grafeno e dos substratos poliméricos, em conjunto com os dados obtidos dos dispositivos fotovoltaicos orgânicos fabricados a partir destes. Neste capítulo também é feita uma descrição do método de transferência de grafeno desenvolvido neste trabalho.

Por fim, as considerações finais são apresentadas no Capítulo 5, concatenando todos os resultados obtidos, apresentando uma conclusão final e a importância deste trabalho para a Eletrônica Orgânica. Neste tópico também é relatado os eventos, trabalhos e publicações originadas ao longo deste doutoramento, bem como as perspectivas para este trabalho.

As referências bibliográficas utilizadas nesta tese são indicadas no Capítulo 6. 


\section{2 \\ Fundamentação teórica}

Neste capítulo, inicialmente são apresentados os polímeros conjugados e as propriedades que permitem a sua utilização como camadas fotossensíveis em dispositivos fotovoltaicos orgânicos. A seguir são discutidos a estrutura, os princípios de funcionamento e os principais parâmetros empregados na caracterização e comparação dos dispositivos fotovoltaicos orgânicos. Na sequência, são apresentadas duas estruturas amplamente empregadas em dispositivos fotovoltaicos: heterojunção em bicamada e heterojunção de volume. Além disso, um breve relato sobre a evolução dos dispositivos fotovoltaicos orgânicos é apresentado. Ainda neste capítulo é apresentado o grafeno como eletrodo condutor e transparente, onde é discutida uma breve fundamentação teórica sobre a estrutura eletrônica do grafeno, suas principais propriedades, as diferentes estratégias de produção e o crescimento em substratos de cobre pelo método CVD, bem como sua transferência para substratos arbitrários. Por fim, os substratos poliméricos flexíveis, onde são brevemente apresentadas as principais propriedades que um substrato deve ter para ser aplicado em dispositivos e os materiais rígidos e flexíveis que hoje são utilizados para este fim.

\section{1}

\section{Polímeros conjugados}

A configuração eletrônica de um átomo de carbono, no seu estado fundamental, é descrita por $1 s^{2} 2 s^{2} 2 p^{3}$. Dessa forma, os elétrons de valência podem se organizar em três distintos estados de hibridização, denominados de $\mathrm{sp}, \mathrm{sp}^{2} \mathrm{e} \mathrm{sp}^{3}$.

O estado de hibridização é responsável pela formação das ligações duplas $(\mathrm{C}=\mathrm{C})$, também chamadas de ligação $\pi$ e das ligações simples (C-C), chamadas de $\sigma$, as quais são responsáveis pelas propriedades físico-químicas dos materiais à base de carbono, dentre estes o diamante, grafite, grafeno e os polímeros conjugados, conforme será descrito na sequência. 
Cada ligação dupla apresenta uma ligação $\pi$ e uma $\sigma$. A ligação $\sigma$ é responsável pela ligação covalente entre os átomos de carbono e, portanto, é considerada uma ligação forte e de alta energia. Já a ligação $\pi$ tem caráter mais fraco e, portanto, é menos energética, sendo esta delocalizada ao longo da estrutura do material. Esta ligação é a responsável pela condução elétrica e térmica, por exemplo, dos materiais com hibridização $\mathrm{sp}^{2}$, a qual é típica do grafeno e dos polímeros conjugados.

Os polímeros conjugados são caracterizados pela alternância entre ligações simples e duplas entre os átomos de carbono adjacentes.

Diferentemente do que acontece no diamante, o qual possui estado de hibridização $\mathrm{sp}^{3}$, a configuração eletrônica de menor energia para os polímeros conjugados é aquela no qual os átomos de carbono possuem três orbitais híbridos $\mathrm{sp}^{2}$. Neste estado de hibridização, os átomos de carbono apresentam três elétrons com ligações $\sigma$ e um orbital remanescente $p_{z}$ perpendicular ao plano dos orbitais $\mathrm{sp}^{2}$. O orbital remanescente torna-se o responsável pela ligação tipo $\pi$, a qual se mantém delocalizada ao longo da cadeia polimérica.

A delocalização deste elétron é a principal responsável pelo comportamento semicondutor desta classe de materiais e por isso, muitas vezes os polímeros conjugados também são denominados de sistemas $\pi$ - conjugados. A Figura 2 mostra alguns exemplos de polímeros conjugados e moléculas pequenas, destacando a presença das ligações simples de duplas alternadas.

Os materiais orgânicos podem ser divididos em moléculas pequenas e polímeros conjugados. As moléculas pequenas são compostos orgânicos que possuem baixo peso molecular, em contraste com os polímeros (poli = muitos e mero = partes) que consistem da interação de vários monômeros percursores e, portanto, resultando em um composto de alto peso molecular. As moléculas pequenas, tais como benzeno, CuPc e PCBM, por exemplo, apresentam alternância de ligações simples e duplas entre os átomos de carbono adjacentes, o qual resulta na formação do orbital remanescente $p_{z}$, semelhante ao que ocorre nos polímeros conjugados. 


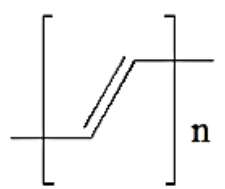

Poliacetileno

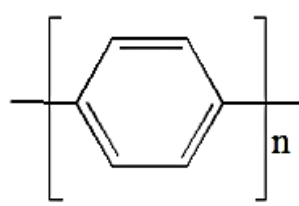

Poli(p-fenileno)

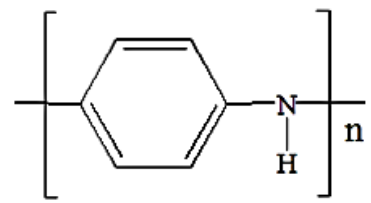

Polianilina

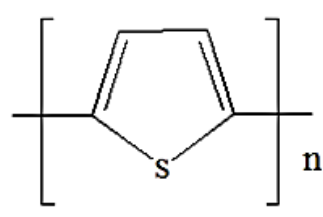

Politiofeno

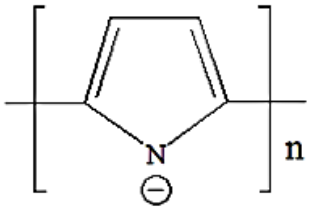

Polipirrol

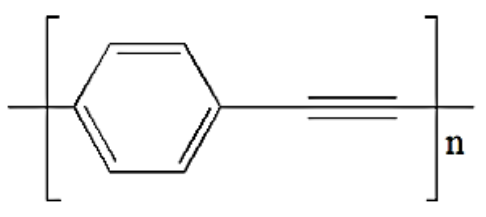

Poli(p-fenileno etinileno)<smiles>c1ccccc1</smiles>

Benzeno

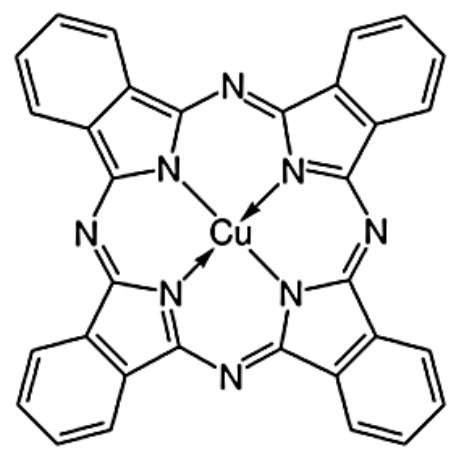

Ftalocianinas cobre ( $\mathrm{CuPc})$

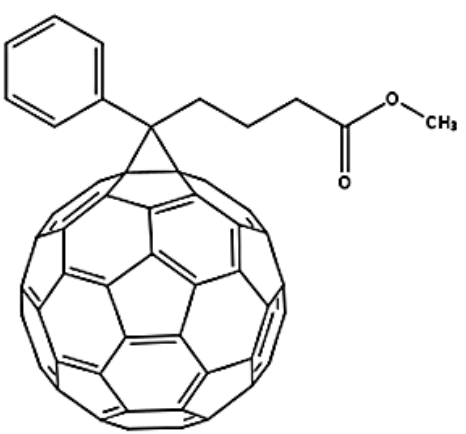

[6,6]Fenil-C61-ácido butírico metil ester (PCBM)

Figura 2: Exemplos de polímeros conjugados e moléculas pequenas utilizados na área da eletrônica orgânica.

\subsection{1}

\section{Transporte de cargas em semicondutores orgânicos}

Em uma cadeia polimérica infinita, a interação entre os orbitais $\pi$ faz com que os elétrons fiquem totalmente delocalizados, podendo estar em qualquer ponto da cadeia. Contudo, esta total delocalização não ocorrem nos polímeros reais, visto que suas cadeias poliméricas não são infinitas. De modo geral, os polímeros conjugados podem apresentar diferentes comprimentos de suas cadeias e diferentes comprimentos de conjugação efetiva [Figura 3 (a)], podendo eventualmente haver agrupamentos de segmentos conjugados levando a uma interação entre os elétrons $\pi$ em diferentes regiões do polímero, causando uma alteração nos níveis eletrônicos. Sendo assim, devido a essa distribuição do comprimento de conjugação ao longo da cadeia, tem-se uma distribuição nos valores de energia, conforme mostra a Figura 3 (b). 
(a)

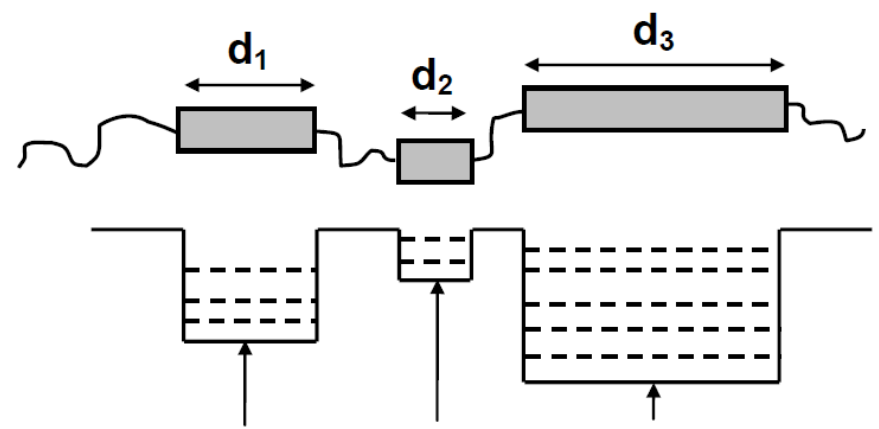

(b)

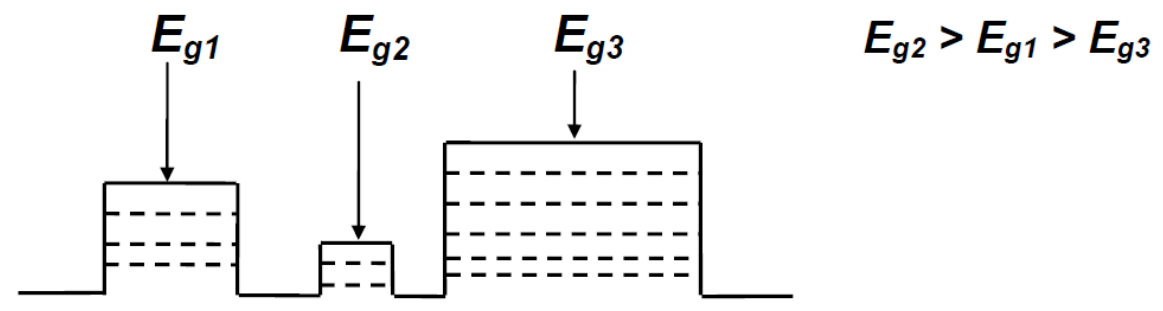

Figura 3: Representação esquemática de uma cadeia polimérica com (a) diferentes comprimentos de conjugação e (b) sua respectiva distribuição de energias de banda proibida. [26]

Neste caso, ocorre a formação de uma distribuição de estados eletrônicos nos polímeros conjugados, de forma similar ao de uma estrutura de banda de energia, mas de forma mais dispersa, em virtude dos distintos processos de interações entre os orbitais atômicos $p_{z}$. O orbital molecular mais alto ocupado (HOMO, do inglês Highest Occupied Molecular Orbital) está relacionado ao estado $\pi$ ligante e o orbital molecular mais baixo desocupado (LUMO, do inglês Lowest Unoccupied Molecular Orbital) está relacionado ao estado anti-ligante $\pi^{*}$. As interações entre orbitais $\pi$ ligantes (ocupados) equivalem à banda de valência e as interações entre orbitais $\pi^{*}$ anti-ligantes (desocupados) equivalem à banda de condução.

A diferença entre o HOMO e o LUMO fornece a energia de banda proibida, também chamado de "gap", possuindo valores entre 1 e 3 eV [27], o qual atua como uma barreira energética para o transporte de carga no semicondutor orgânico. Além disso, poderão existir níveis energéticos dentro da banda proibida, devido à presença de defeitos químicos ou estruturais no material, também conhecidos como armadilhas.

Em virtude da variação do comprimento de conjugação e da formação dos distintos estados energéticos, existe uma distribuição dos sítios de transporte de carga, aproximado na forma de uma distribuição gaussiana $D(E)$, a qual reflete na desordem do sistema, conforme ilustrado na Figura 4. 


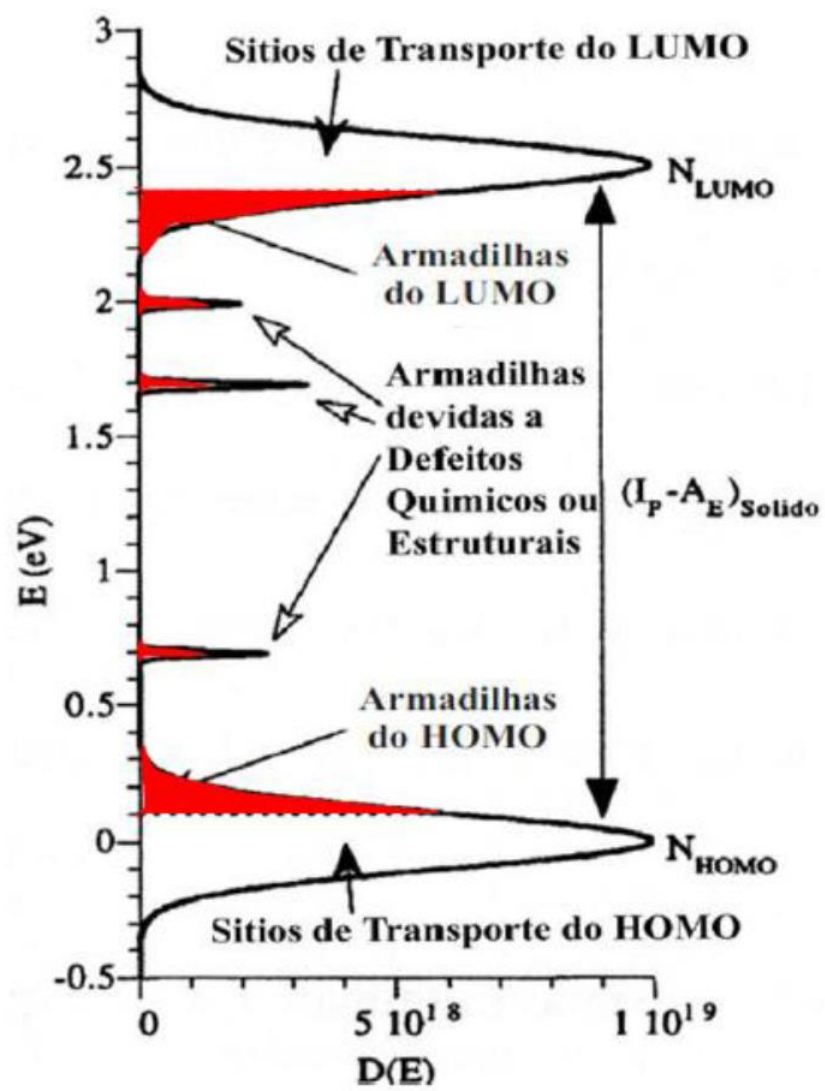

Figura 4: Distribuição gaussiana dos níveis energéticos, mostrando a formação do HOMO, LUMO e das armadilhas no interior da banda proibida. Adaptado de [28]

O transporte de carga entre os estados energéticos, mostrados na Figura 4, ocorre por tunelamento quântico assistido por fônons, chamados de saltos ou hopping, em inglês. O hopping é termicamente ativado e o portador de carga se desloca entre as cadeias moleculares, tunelando as barreiras de energia entre os estados energéticos localizados no interior do material.

Outra justificativa para a formação de uma distribuição gaussiana dos níveis energéticos nos semicondutores orgânicos decorre da forte interação entre elétrons e fônons. Isto porque um elétron ou um buraco pode distorcer a rede molecular, formando uma quase-partícula chamada de pólaron, podendo esta ser negativa ou positiva, respectivamente, conforme ilustrado na Figura 5 (a).

Com o aumento da quantidade de defeitos estruturais ou químicos (armadilhas), dois pólarons em uma única cadeia podem coalescer em um "bipólaron" criando uma deformação duplamente carregada em um sistema $\pi$ conjugado, conforme ilustra a Figura 5 (b). 

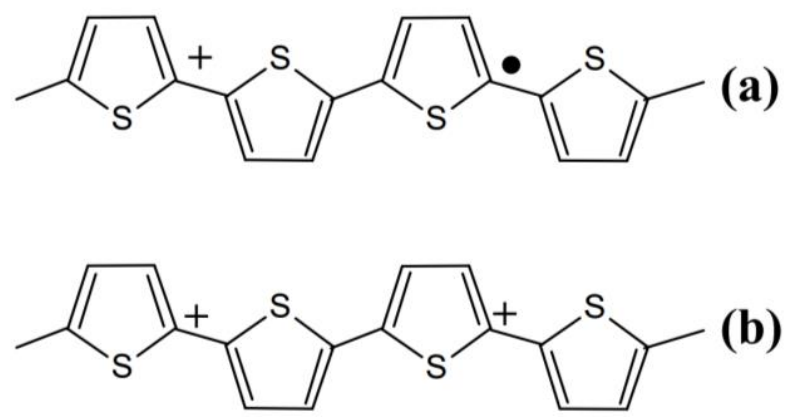

Figura 5: Ilustração esquemática de uma cadeia de politiofeno com presença de (a) um pólaron positivo e (b) um bipólaron positivo. [26]

\subsection{2}

\section{Formação de éxcitons}

Dependendo da energia de incidência de um fóton sobre um material orgânico, poderá ocorrer a excitação de um elétron para um nível mais energético neste material. Dessa forma, um elétron poderá ser promovido do nível energético HOMO para o LUMO.

A vacância de um elétron (ou buraco) no nível HOMO e o elétron no nível LUMO geram a formação de um par elétron-buraco, chamado de éxciton. Esta interação ocorre por meio de forças coulombianas, contudo, diferente das excitações carregadas (pólarons, por exemplo), esta é neutra. A Figura 6 mostra as duas possíveis formação de éxcitons.

(a)

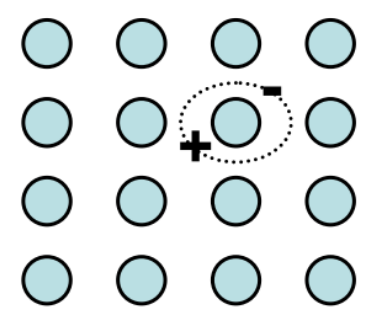

(b)

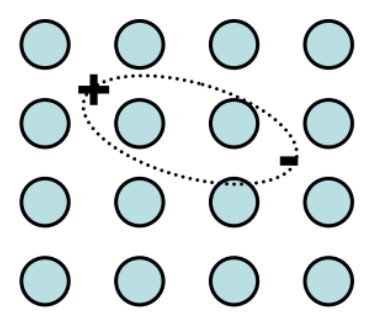

Figura 6: Ilustração das possíveis formações de éxcitons em semicondutores orgânicos: (a) éxciton Frenkel e (b) éxciton de transferência de carga. Adaptado de [26]

Os materiais orgânicos possuem baixos valores para a constante dielétrica, comparado aos materiais inorgânicos. Por este motivo, a interação entre o elétron e o buraco torna-se forte e de curta distância. Desse modo, o éxciton criado em semicondutores orgânicos tende a permanecer na unidade molecular e são chamados de éxcitons moleculares ou éxcitons de Frenkel. Os éxcitons de Frenkel tem uma energia de 
ligação na ordem de $100 \mathrm{meV}$. Casos em que o éxciton se localiza sobre unidades adjacentes também são observados em sistemas orgânicos. Pares elétron-buraco, em que cada carga está em uma unidade diferente são chamados de éxciplex ou éxcitons de transferência de cargas. [26, 29]

\section{2 \\ Dispositivo fotovoltaico orgânico}

Os dispositivos fotovoltaicos orgânicos (OPV, do inglês Organic Photovoltaic) são dispositivos baseados na Eletrônica Orgânica, capazes de converter energia solar em energia elétrica. Estes podem ser divididos em dois tipos dependendo da sua aplicação tecnológica: detecção de luz (fotodetectores) ou conversão de energia elétrica (células solares). Para um fotodetector é suficiente apresentar sensibilidade para apenas um comprimento de onda. Por outro lado, as células solares devem possuir uma ampla sensibilidade à faixa de emissão do espectro solar.

Um dispositivo fotovoltaico orgânico consiste basicamente de uma ou mais camadas de materiais semicondutores orgânicos (polímeros conjugados ou moléculas pequenas) compondo a camada ativa (fotossensível) e que é disposto entre dois eletrodos condutores (catodo e ânodo) com diferentes valores de função trabalho (energia necessária para arrancar um elétron), sobre um substrato, como é ilustrado na Figura 7.

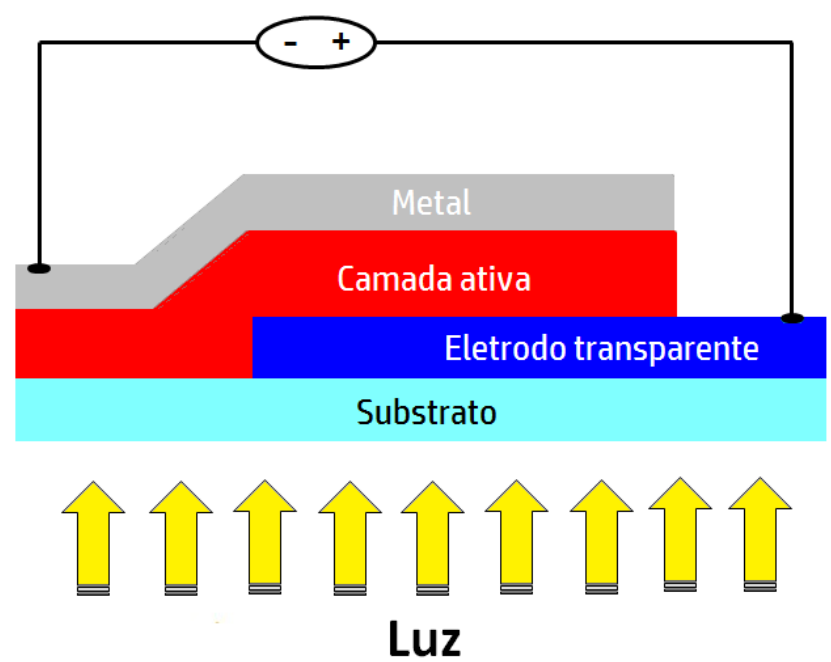

Figura 7: Diagrama esquemático de uma estrutura típica de um dispositivo fotovoltaico orgânico, onde o substrato e o eletrodo devem ser transparentes para que a luz incidente possa atingir a camada ativa do dispositivo. 
$\mathrm{Na}$ estrutura de um dispositivo fotovoltaico orgânico um dos eletrodos deve ser necessariamente transparente para que a luz possa atravessá-lo sem grandes perdas e, sequencialmente, ser absorvida pela camada ativa do dispositivo. Nos dispositivos fotovoltaicos orgânicos tradicionais, o eletrodo condutor transparente atua como o ânodo e, em sua maioria, é formado por filmes finos de óxidos condutores transparentes (ITO, FTO, $\mathrm{ZnO}_{2}$, entre outros), nanopartículas metálicas, nanotubos de carbono, grafeno, sendo que o mais utilizado é o ITO $[11,30]$. O cátodo não precisa ser necessariamente transparente e geralmente são utilizados filmes finos metálicos, tais como Al, Ag, Ca, entre outros.

A camada ativa de um dispositivo fotovoltaico orgânico pode ser composta por uma ou mais camadas orgânicas, onde cada camada possui uma função bem específica e dependem fundamentalmente dos níveis energéticos HOMO e LUMO, conforme descrito anteriormente. Na seção 2.2.3 deste capítulo é feita uma discussão sobre a influência da camada ativa na estrutura do dispositivo, sendo apresentadas as estruturas com heterojunção em bicamada e em volume.

\subsection{1}

\section{Princípio de funcionamento de um dispositivo fotovoltaico orgânico}

O mecanismo de conversão de energia dos dispositivos fotovoltaicos orgânicos origina-se através dos fótons incidentes na camada ativa, os quais são transformados em fotocorrentes, como ilustrado na Figura 8, podendo ser descritos basicamente em quatro etapas:

(1) Geração do éxciton: Os fótons incidentes com energia superior ou igual ao "gap" de energia dos materiais da camada ativa são absorvidos, causando fotoexcitações e, consequentemente, promovendo a formação de um par elétron-buraco ligado para cada fóton absorvido. A vacância de um elétron (ou buraco) no nível HOMO e o elétron no nível LUMO geram a formação do éxciton, cuja energia típica de ligação dos éxcitons é de 0,3 a 1,0 eV [31].

(2) Difusão do éxciton: Após a geração do par elétron-buraco, este se difunde através da camada ativa até alcançar a interface do semicondutor orgânico/metal (camada ativa com apenas um material orgânico - monocamada) ou dos semicondutores orgânicos 
(camada ativa com dois materiais orgânicos - bicamada). Materiais orgânicos tem estados excitados localizados e os éxcitons formados tem um curto caminho de difusão (10-20 nm), sendo o tempo de vida da ordem de nanosegundos [32]. Por essa razão, a espessura da camada polimérica deve ser da ordem de dezenas de nanômetros.
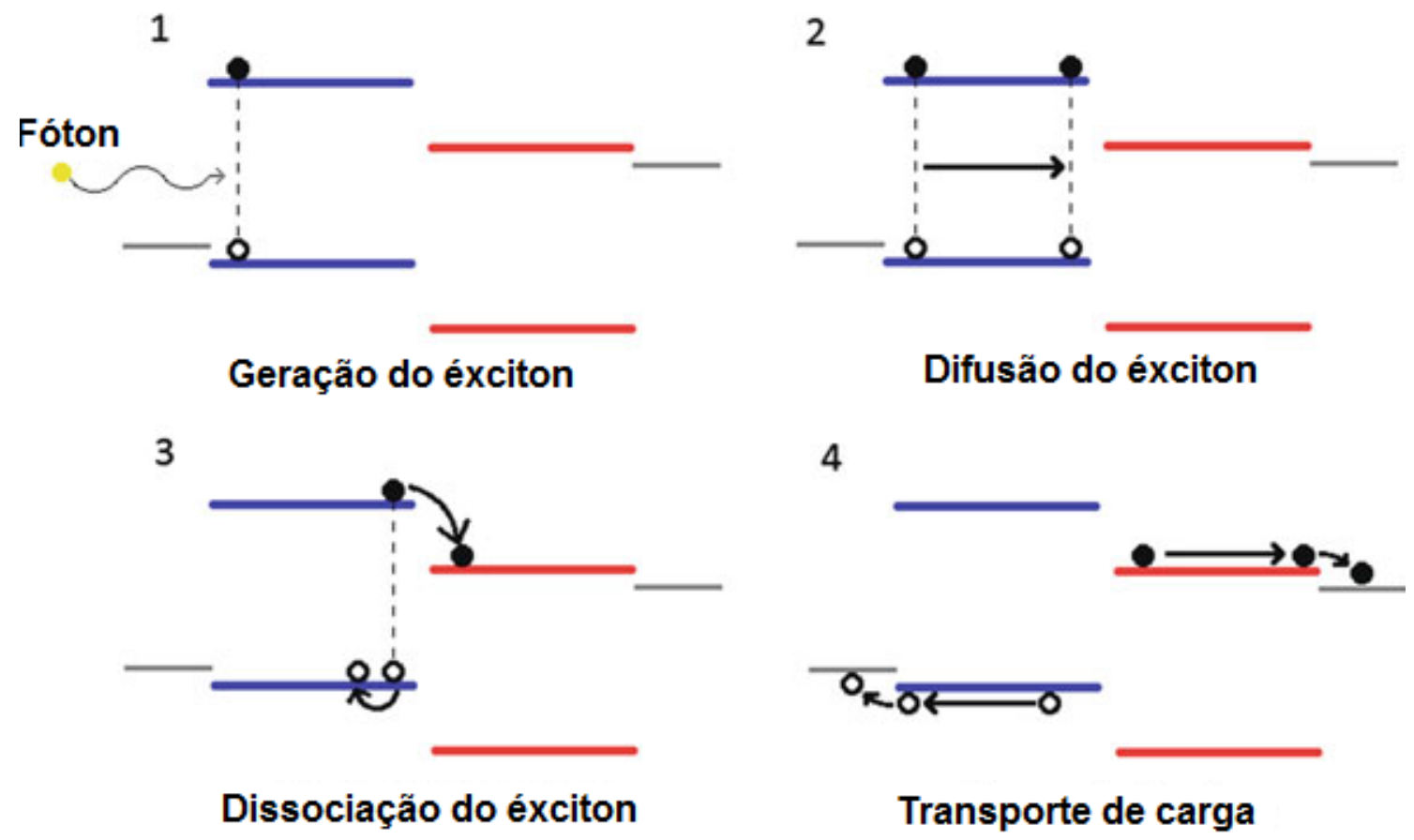

Figura 8: Ilustração esquemática do mecanismo de conversão de fótons incidentes em fotocorrente em um dispositivo fotovoltaico orgânico. [33]

(3) Dissociação do éxciton: O par elétron-buraco ao alcançar a interface do semicondutor orgânico/metal ou a interface dos semicondutores orgânicos se dissocia, convertendo o par ligado elétron-buraco em cargas livres para serem trasportadas em um circuito externo. No caso da utilização de apenas um material orgânico como camada ativa (monocamada), a dissociação ocorre em regiões de alto campo elétrico, normalmente encontrada próxima à interface semicondutora orgânico/metal. Quando são utilizados dois materiais orgânicos (bicamada), a dissociação ocorre na interface desses materiais, devido à diferença entre os seus níveis de energia. Na seção 2.2.3 é descrito em mais detalhes o processo de dissociação do éxciton para uma estrutura com dois materiais compondo a camada ativa.

(4) Transporte de cargas: A maioria das cargas livres criadas são transportadas até seu respectivo eletrodo e coletada por um circuito externo, gerando uma corrente 
elétrica disponível nos terminais. As demais cargas livres podem se recombinarem, por exemplo, não sendo transportadas até o seu respectivo eletrodo. Vale acrescentar que o mecanismo de geração e coleta das cargas é complexo e dependente de inúmeros fatores, como a mobilidade da camada ativa, cristalinidade, direção de empacotamento, do substrato, morfologia dos filmes orgânicos e principalmente dos níveis de energia dos semicondutores orgânicos, determinante na eficiência do dispositivo fotovoltaico orgânico.

\subsection{2}

\section{Caracterização de dispositivos fotovoltaicos orgânicos}

A caracterização de um dispositivo fotovoltaico é obtida pela comparação de suas curvas características de densidade de corrente em função da tensão aplicada $(J \times V)$, no escuro e sob iluminação. A partir do comportamento das curvas características $J \times V$ alguns parâmetros fundamentais para a comparação entre dispositivos são determinados, tais como: densidade de corrente de curto circuito (Jsc), tensão de circuito aberto (Voc), fator de preenchimento (FF) e eficiência de conversão de potência (PCE).

A Figura 9 ilustra as curvas características $\mathrm{J} \times \mathrm{V}$ para o comportamento ideal de um dispositivo fotovoltaico no escuro e sob iluminação. A curva no escuro representa a resposta elétrica compatível a um diodo retificador, no qual a densidade de corrente elétrica é diferente de zero apenas quando um potencial externo é aplicado. Sob iluminação a curva característica $\mathrm{J} \times \mathrm{V}$ sofre um deslocamento, conforme ilustra a Figura 9, devido à formação de densidade de corrente elétrica diferente de zero.

Como vimos na seção anterior, as dissociações dos éxcitons geram portadores de cargas livres que são transportados para os eletrodos. Este transporte de carga é devido ao campo elétrico gerado pela diferença entre as funções trabalho dos eletrodos, o qual cria um potencial elétrico intrínseco (potencial de “built in”) entre os eletrodos do dispositivo, resultando em uma densidade de corrente elétrica mesmo sem a aplicação de um potencial elétrico externo. Essa densidade de corrente recebe o nome de densidade de corrente de curto circuito $\left(\mathrm{J}_{\mathrm{SC}}\right)$. [27, 34] Quando um potencial elétrico externo é aplicado ao dispositivo, a densidade de corrente elétrica diminui até que o potencial elétrico interno seja equilibrado. A diferença de potencial aplicada ao dispositivo que equilibra o potencial elétrico interno é chamada de tensão de circuito aberto $\left(\mathrm{V}_{\mathrm{oc}}\right)$, podendo ser estimada conforme ilustra a Figura 9. 


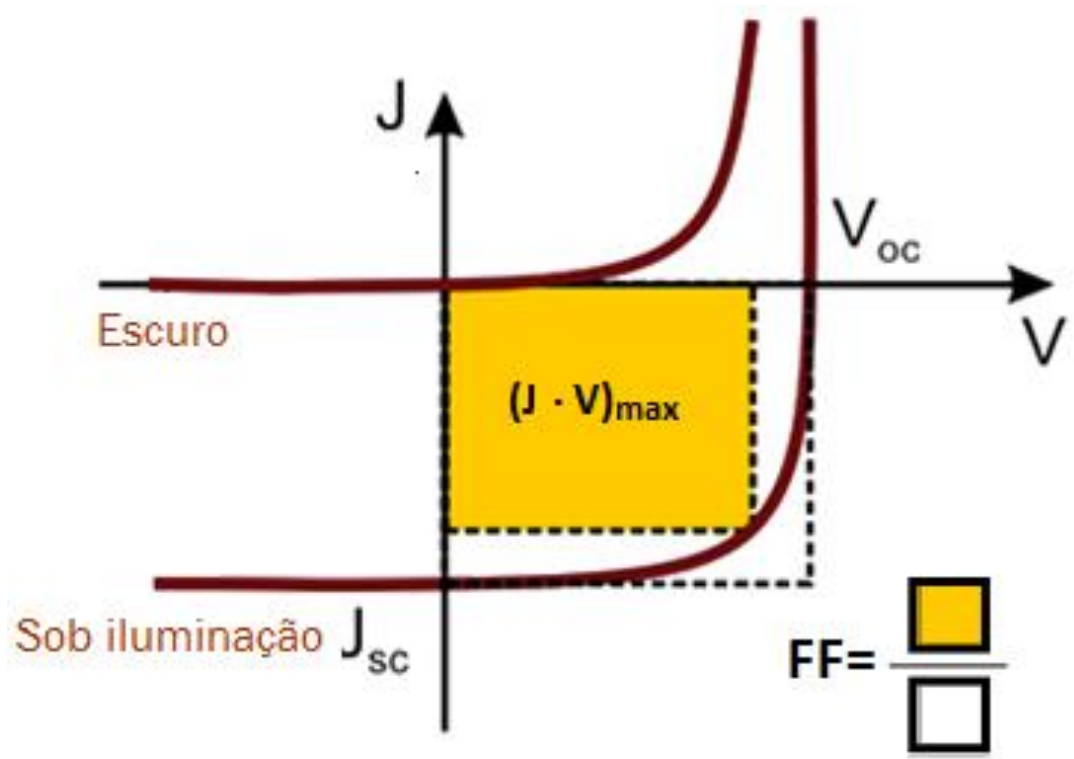

Figura 9: Curvas características $\mathrm{J} \times \mathrm{V}$ para um dispositivo fotovoltaico no escuro e sob iluminação, indicando os principais parâmetros utilizados para a sua caracterização.

A Figura 10 mostra um diagrama de níveis de energia para um dispositivo fotovoltaico monocamada no escuro e sob iluminação, respectivamente.

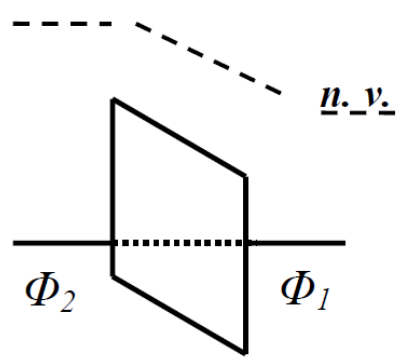

Polímero

(a) $V_{a p l}=0$

(b) $V_{O C} \approx V_{i}$

Figura 10: Diagrama de níveis de energia para um dispositivo fotovoltaico cátodo/monocamada/ ânodo: (a) no escuro e (b) sob iluminação. [26, 34]

Quando os eletrodos e a camada ativa são colocados em contato forma-se um balanceamento de cargas entre os materiais de diferentes funções trabalho $\left(\Phi_{1}\right.$ e $\left.\Phi_{2}\right)$ até que atinjam o equilíbrio de cargas elétricas. Nesta situação, os níveis de Fermi dos eletrodos ficam nivelados e um potencial elétrico interno é criado no interior do dispositivo, conforme ilustra a Figura 10 (a). Quando o dispositivo é submetido à iluminação e após a dissociação dos éxcitons, os portadores de cargas são transportados 
para os eletrodos devido à presença do potencial elétrico interno. Isso faz com que a função trabalho $\left(\Phi_{1}\right)$ do cátodo aumente e a função trabalho do ânodo $\left(\Phi_{2}\right)$ diminua, quase atingindo a condição de uma banda de energia nivelada (plana), criando uma diferença de potencial definida como tensão de circuito aberto $\left(\mathrm{V}_{\mathrm{oc}}\right)$, conforme mostra a Figura 10 (b). $[26,34]$

No caso de um dispositivo monocamada, a $\mathrm{V}_{\mathrm{oc}}$ está relacionada com a diferença entre as funções trabalho dos eletrodos. No caso de dispositivos em heterojunção de um material doador de elétrons e um material aceitador, a $\mathrm{V}_{\mathrm{oc}}$ está diretamente relacionada com a diferença de energia entre o HOMO do material doador e o LUMO do aceitador, de acordo expressão abaixo:

$$
V_{o c}=\frac{1}{e}\left(\left|E_{\text {Doador }}^{\text {HOMo }}\right|-\left|E_{\text {Aceitador }}^{L U M O}\right|-K_{B} \operatorname{Tln}\left(\frac{G}{\gamma N_{h} N_{e}}\right)\right) \quad \text { Equação } 1
$$

onde G é uma constate, $\gamma$ é o coeficiente de taxa de recombinação, $N_{h}$ e $N_{e}$ são a densidade de buracos e elétrons, respectivamente. [27, 35]

Assim sendo, como ilustrado nas Figuras 23 e 24, diversos parâmetros podem ser obtidos a partir das curvas características $\mathrm{J} \times \mathrm{V}$, os quais foram utilizados para a caracterização dos dispositivos fabricados nesta tese. Conforme previamente detalhado, podemos descrever de forma genérica os seguintes parâmetros, de forma a melhorar a compreensão do leitor neste momento:

- $\quad$ Densidade de corrente de curto circuito $\left(\mathrm{J}_{\mathrm{SC}}\right)$

A densidade de corrente de curto circuito corresponde à densidade de corrente que percorre o dispositivo sob iluminação, quando nenhuma tensão externa é aplicada (V = $0)$.

- $\quad \underline{T e n s a ̃ o ~ d e ~ c i r c u i t o ~ a b e r t o ~}\left(V_{O C}\right)$

A tensão de circuito aberto é a diferença de potencial aplicada entre os eletrodos quando a densidade de corrente elétrica é suprimida $(\mathrm{J}=0)$. 
- $\quad \underline{\text { Fator de preenchimento }}$

$\mathrm{O}$ fator de preenchimento (FF, do inglês Fill Factor) é uma medida que referencia a qualidade do dispositivo fotovoltaico orgânico e é dado pela razão entre a potência máxima fornecida pelo dispositivo e sua potência nominal, sendo descrita por:

$$
\boldsymbol{F F}=\frac{(J V)_{\max }}{J_{S C} V_{O C}}
$$

onde J e V são os valores para a densidade de corrente e tensão aplicada que maximizam o produto. $\mathrm{O}$ fator de preenchimento depende do formato das curvas $\mathrm{J} \times \mathrm{V}$. No caso de um dispositivo ideal, sem considerarmos perdas por recombinação de cargas e dissipação de energia por efeito Joule nos eletrodos e no interior da camada ativa, a potência máxima que o dispositivo pode extrair é o produto de Jsc por Voc, o que resulta em um FF igual a 1 (ou 100\%).

- Eficiência de conversão de potência

A eficiência de conversão de potência (PCE, do inglês Power Conversion Efficiency) é definido como a porcentagem de energia luminosa convertida em energia elétrica, a qual é calculada a partir da potência elétrica máxima gerada pelo dispositivo $\left(\mathrm{P}_{\text {máx }}\right)$ em razão da potência de luz incidente $\left(\mathrm{P}_{\mathrm{in}}\right)$ :

$$
\boldsymbol{\eta}=\frac{P_{\text {máx }}}{P_{\text {in }}}=\frac{(J V)_{\text {máx }}}{I_{0}}
$$

onde $\mathrm{I}_{0}$ é intensidade de luz incidente no dispositivo. Em termos do fator de preenchimento FF, a expressão para o cálculo de $\eta$ é:

$$
\eta=F F \frac{J_{S C} V_{o C}}{I_{0}}
$$

Equação 4

O procedimento padrão para determinação da eficiência $\eta$ de um dispositivo fotovoltaico consiste na realização da medida tipo $\mathrm{J} \times \mathrm{V}$ sob iluminação de luz branca com intensidade de $100 \mathrm{~mW} / \mathrm{cm}^{2}$ (equivalente a $1 \mathrm{sol}$ ) com filtro AM 1.5G, o qual representa 
o espectro de radiação do sol na superfície da Terra medido a um ângulo de 48,18 $\mathrm{em}$ relação à normal, conforme orienta a ISO 9845-1:1992. A Figura 11 mostra o espectro da radiação solar simulado AM 1.5G na superfície da Terra. Observa-se que a maior intensidade de emissão é entre $400 \mathrm{~nm}$ a $750 \mathrm{~nm}$. Sendo assim, materiais orgânicos que absorvam nessa região são mais favoráveis para a aplicação em dispositivos fotovoltaicos orgânicos.

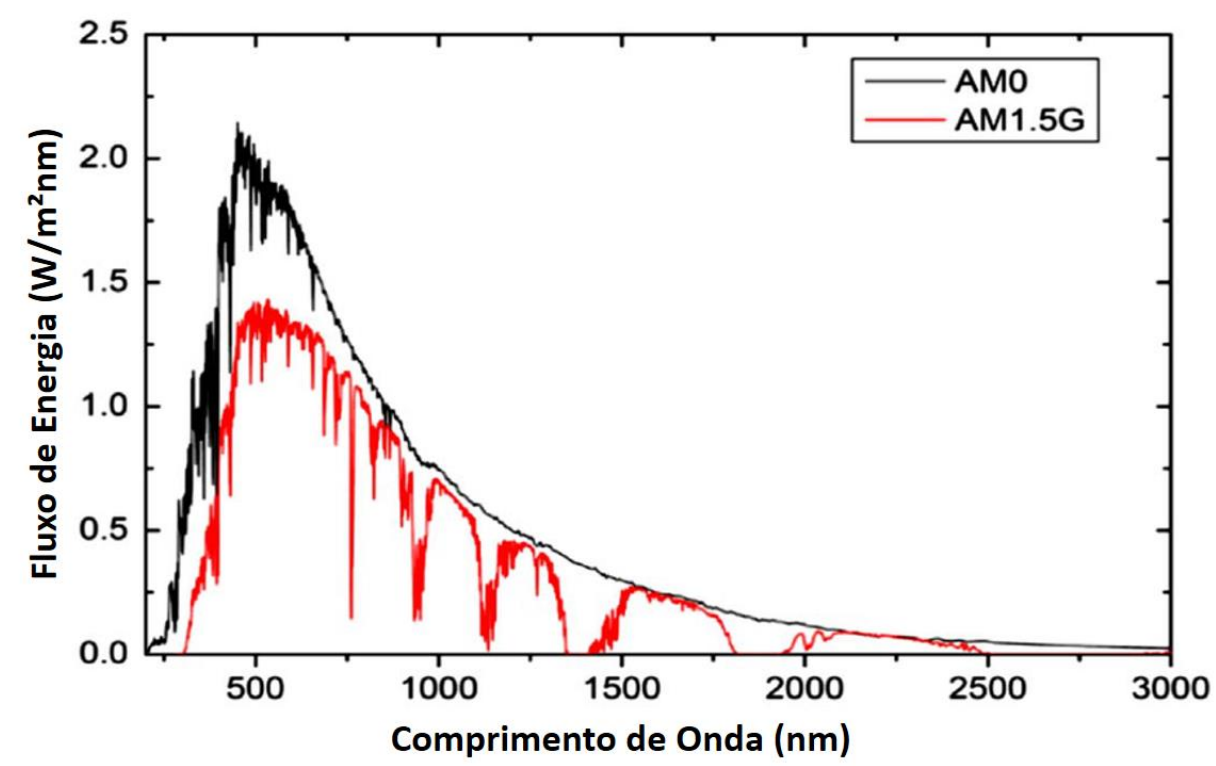

Figura 11: Espectro da radiação solar com filtro AM 0 e AM 1.5G. Adaptado de [36]

Para um dispositivo fotovoltaico orgânico absorver mais fótons, deve haver uma máxima sobreposição entre o espectro de absorção do material orgânico e o espectro de emissão solar. O número máximo de fótons absorvidos pela camada ativa do dispositivo, dentro do intervalo de comprimento de onda da emissão solar, é determinado pelo gap de energia dos semicondutores orgânicos utilizados. Um semicondutor com baixo valor de gap de energia absorve uma porção maior do espectro solar, entretanto os fótons com excesso de energia (energia acima do gap de energia do semicondutor orgânico) são rapidamente dissipados pela liberação de fônons, limitando o aumento da eficiência de conversão de potência do dispositivo. Como a maioria dos semicondutores orgânicos possuem gap de energia relativamente altos, em torno de 1 a $3 \mathrm{eV}$, o espectro de absorção tende a ser estreito (quando comparado a materiais inorgânicos) e apenas uma pequena fração do espectro solar é absorvido.

Outro parâmetro importante para a caracterização de um dispositivo fotovoltaico é a eficiência quântica externa (IPCE, do inglês Incident Photon to Converted Electron), a 
qual indicada o perfil de contribuição de absorção da camada ativa para a fotocorrente gerada. A IPCE é obtida pela medida da resposta elétrica do dispositivo sob iluminação monocromática em vários comprimentos de onda $(\lambda)$, sem tensão aplicada, ou seja, é a medida da densidade de corrente $\mathrm{J}_{\mathrm{SC}}$ em função do comprimento de onda. Portanto, a IPCE é essencialmente descrita pela razão entre o número de portadores de cargas coletados nos eletrodos e o número de fótons que incide na camada ativa para cada comprimento de onda.

O número de portadores de cargas geradas é expresso em função de $\mathrm{J}_{\mathrm{SC}}$ da seguinte forma:

$$
N_{c}=\frac{J_{s c}}{e}
$$

onde e é a carga elétrica elementar. O número de fótons que incide sobre o dispositivo pode ser expresso por:

$$
N_{f}=\frac{\lambda I_{\lambda}}{h c}
$$

Equação 6

onde $\lambda$ é o comprimento de onda, $\mathrm{I}_{\lambda}$ é a intensidade da luz incidente (dada $\mathrm{em}^{-2}$ ), h é a constante de Planck e c é a velocidade da luz no vácuo.

Assim sendo, fazendo a relação entre o número de portadores de cargas gerados $\left(\mathrm{N}_{\mathrm{c}}\right)$ pelo número de fótons incidentes $\left(\mathrm{N}_{\mathrm{f}}\right)$ e substituindo os valores das constantes, obtemos que:

$$
\operatorname{IPCE}(\%)=\frac{N_{c}}{N_{f}}=1240 \frac{J_{s C}}{\lambda I_{\lambda}}
$$

\subsection{3}

\section{Estruturas com heterojunções em bicamada e em volume}

Durante a década de 80, os primeiros dispositivos fotovoltaicos orgânicos foram fabricados utilizando uma monocamada como camada ativa, em uma estrutura tipo sanduíche simples, constituída de um material orgânico entre os eletrodos. Estes dispositivos mostraram uma eficiência de conversão de potência menor do que $1 \%$ [37, 
38]. Este fraco desempenho é, principalmente, devido à forte energia de ligação dos éxcitons que não podem ser eficientemente dissociados.

Uma estratégia para melhorar a taxa de dissociação de éxcitons, foi o desenvolvimento de estruturas com camadas ativas compreendendo o uso de dois semicondutores orgânicos diferentes com níveis energia (HOMO e LUMO) adequados. Essas estruturas são baseadas na combinação de materiais doadores e aceitadores de elétrons que formam uma interface para a dissociação dos éxcitons. Nesse caso, as estruturas são chamadas de heterojunções, que podem ser em bicamada ou em volume. Essas duas estruturas são ilustradas na Figura 12 e são discutidas em maiores detalhes na sequência.

(a)

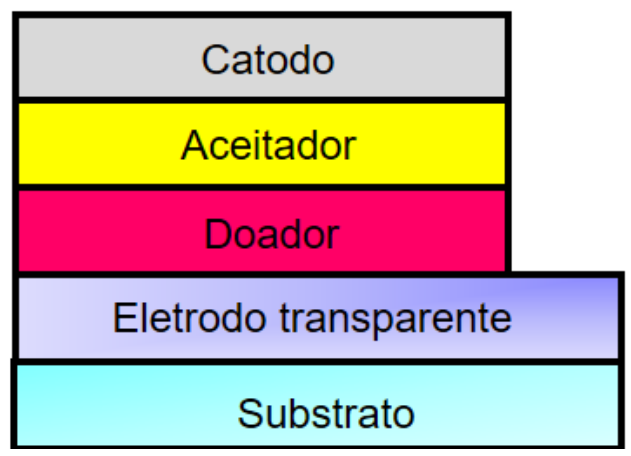

(b)

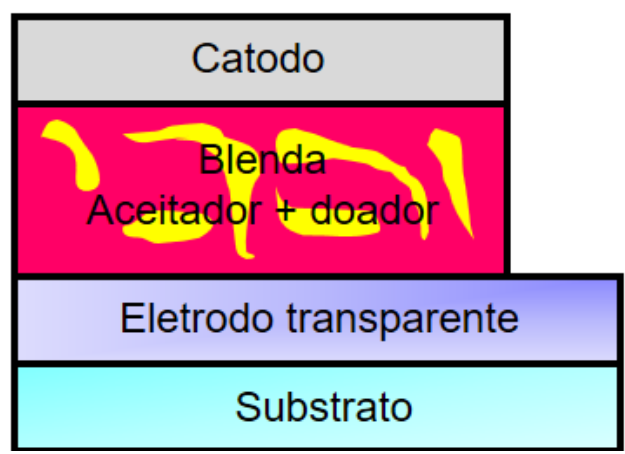

Figura 12: Estruturas em heterojunção utilizadas em dispositivos fotovoltaicos orgânicos: (a) heterojunção em bicamada e (b) heterojunção em volume.

\section{$\underline{\text { Heterojunção em bicamada }}$}

O primeiro dispositivo fotovoltaico orgânico a empregar o método da heterojunção foi reportado por Tang [2], ao utilizar ftalocianina de cobre $(\mathrm{CuPc})$ como semicondutor do tipo p (doador de elétrons) e um derivado de perileno como tipo n (aceitador de elétrons), usando uma estrutura com heterojunção em bicamada entre os eletrodos do dispositivo.

Conforme ilustra a Figura 12 (a), a camada ativa de um dispositivo bicamada é constituída de dois materiais orgânicos com diferentes valores de eletroafinidade, sendo esta propriedade definida como a quantidade de energia liberada por um átomo ao aceitar um elétron e seu valor é a diferença de energia entre o nível de vácuo e o LUMO. Um desses materiais é doador de elétrons e o outro aceitador. 
Nesta estrutura existe uma única interface, sendo bem definida entre o material doador e o aceitador de elétrons, na qual os éxcitons se dissociam. A diferença entre os níveis de energia nessa interface fornece a energia necessária para uma transferência de cargas, no qual os elétrons são transferidos do LUMO do material doador para o LUMO do material aceitador conforme mostra a Figura 13. Além, disso, a diferença de energia entre o HOMO do doador e o HOMO do aceitador forma uma barreira de energia para a transferência do buraco, mantendo-o confinado no estado eletrônico do material doador. [27]

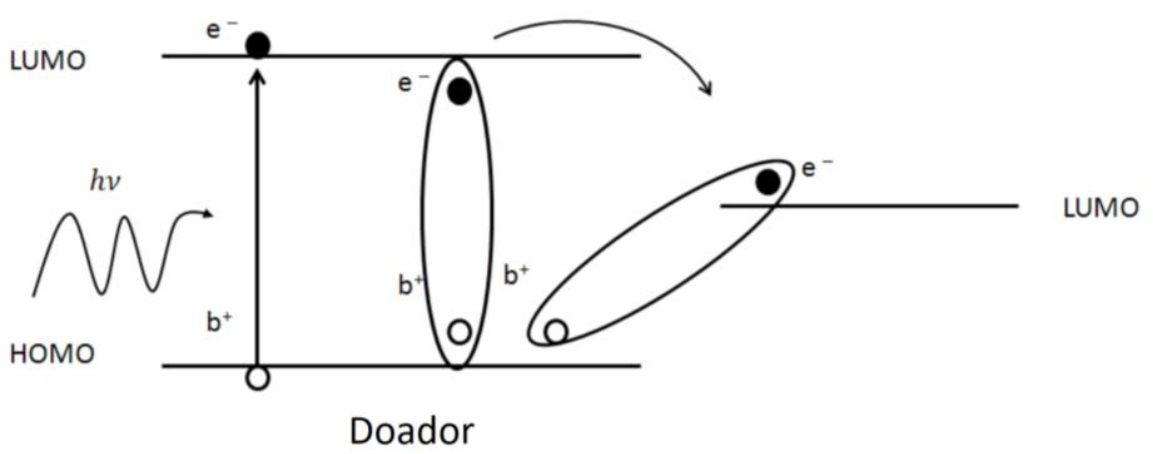

Aceitador

Figura 13: Diagrama dos níveis de energia dos materiais doador e aceitador de elétrons e o processo de transferência de elétron após a dissociação do éxciton. Adaptado de [27].

O principal fator que limita a eficiência dos dispositivos em bicamada é a espessura da camada ativa, que por sua vez, está relacionada com o baixo comprimento de difusão do éxciton, o qual é a distância média percorrida pelo éxciton antes de possíveis recombinações. Como os éxcitons devem alcançar a interface doador/aceitador para serem dissociados, apenas os éxcitons gerados a uma distância próximo ao seu comprimento de difusão ( 10 nm) serão convertidos em portadores de carga livres. Em contrapartida, os éxcitons gerados longe da interface podem recombinar-se entre si, antes de chegar até a interface entre as camadas [27, 39], não contribuindo para a eficiência de conversão de potência do dispositivo. Por este motivo, este tipo de estrutura é indicado apenas para filmes semicondutores com espessuras da ordem de poucos nanômetros.

O fulereno $\left(\mathrm{C}_{60}\right)$ é um dos materiais aceitadores de elétrons mais comumente utilizado na estrutura em bicamada de dispositivos fotovoltaicos orgânicos, sendo o material usado nesta tese. Saricifti e colaboradores [40] constataram que a transferência de elétrons do material doador para o $\mathrm{C}_{60}$ é um processo ultra-rápido e ocorre num 
intervalo de tempo da ordem de fentosegundos. Esse processo é mais rápido do que qualquer processo de recombinação do elétron com o respectivo buraco gerado pela excitação ótica.

A Figura 14 mostra o desempenho de um dispositivo fotovoltaico orgânico com diferentes espessuras de $\mathrm{C}_{60}$ em uma estrutura tipo bicamada de $\mathrm{CuPc} / \mathrm{C}_{60}$. A J $\mathrm{J}_{\mathrm{SC}}$ varia de 3,4 a 4,4 mA/ $\mathrm{cm}^{2}$, enquanto a espessura do $\mathrm{C}_{60}$ varia de 20 a $40 \mathrm{~nm}$, respectivamente. Com espessura de $80 \mathrm{~nm}$ de $\mathrm{C}_{60}$, a $\mathrm{J}_{\mathrm{SC}}$ diminui para $2,37 \mathrm{~mA} / \mathrm{cm}^{2}$. A eficiência de conversão de potência (PCE) variou de $0,82 \%$ (com $20 \mathrm{~nm}$ de $\mathrm{C}_{60}$ ) para 1,02\% (com 40 $\mathrm{nm}$ de $\mathrm{C}_{60}$ ) e depois diminui para $0,52 \%$ (com $80 \mathrm{~nm}$ de $\mathrm{C}_{60}$ ). $\mathrm{O}$ fator de preenchimento não se altera obviamente, devido à alta mobilidade eletrônica do $\mathrm{C}_{60}$, o que não resulta na condição de desequilíbrio de cargas no dispositivo.
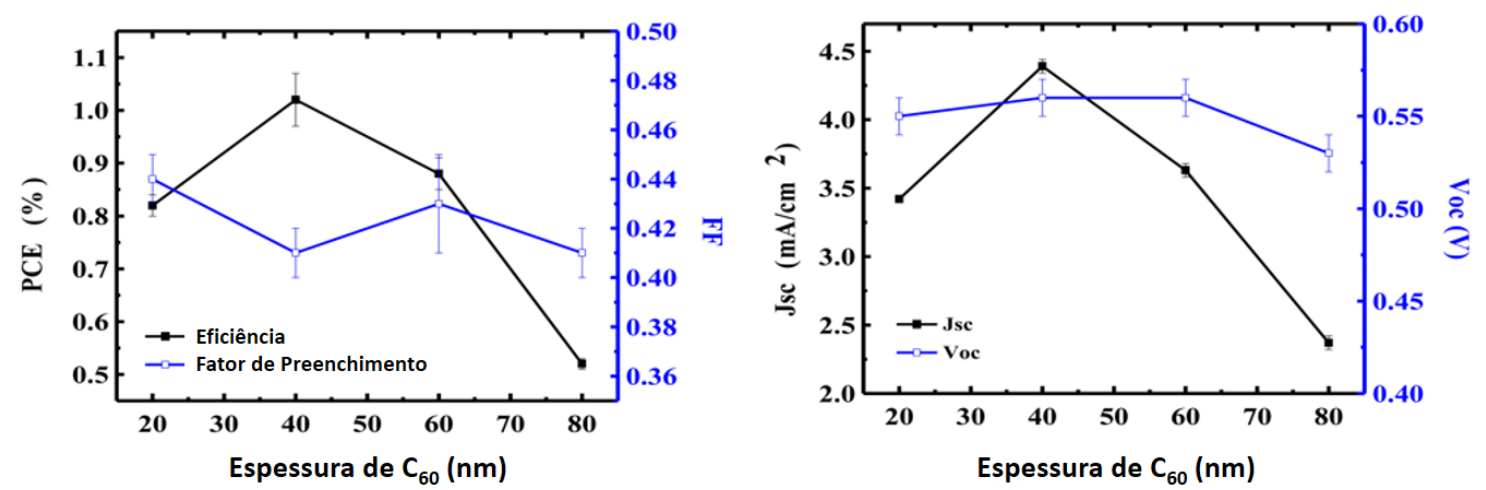

Figura 14: Parâmetros de eficiência de um dispositivo fotovoltaico orgânico com diferentes espessuras do $\mathrm{C}_{60}$. A estrutura do dispositivo consiste: ITO/ CuPc $(20 \mathrm{~nm}) / \mathrm{C60}(\mathrm{X}) / \mathrm{BCP}(7 \mathrm{~nm}) / \mathrm{Ag}(100 \mathrm{~nm})$. Adaptado de $[41]$.

Os materiais orgânicos podem ser depositados por diferentes técnicas, as mais comumente utilizadas são por evaporação térmica resistiva e em solução por spin coating. Essas técnicas são discutidas em maiores detalhes nos próximos capítulos. Um fator importante para as estruturas em bicamada é a baixa solubilidade do $\mathrm{C}_{60}$ em solventes orgânicos, o que faz necessária apenas a utilização da técnica de evaporação térmica resistiva.

\section{$\underline{\text { Heterojunção em volume }}$}

Uma alternativa para aumentar a eficiência de conversão de potência dos dispositivos fotovoltaicos orgânicos surgiu após a síntese de um fulereno solúvel derivado 
do $\mathrm{C}_{60}$, chamado PCBM. Com este material, a heterojunção dos materiais aceitador e doador de elétrons pode ser processada a partir de uma mistura em solução, resultando em uma estrutura chamada heterojunção em volume (BHJ, do inglês bulk heterojunction) esquematizada na Figura 12 (b).

O primeiro dispositivo fotovoltaico orgânico fabricado usando o PCBM como material aceitador de elétrons foi desenvolvido em 1995 por Yu e colaboradores [4]. Neste dispositivo foi usando o polímero poly(2-methoxy-5-(2'-ethyl-hexyloxy)-1,4phenylene vinylene) (MEH-PPV) como material doador de elétrons, resultando num aumento de $50 \%$ em comparação com a primeira célula de heterojunção em bicamada reportada por Tang [2].

Nesta estrutura, os materiais aceitador e doador se emaranham e criam infinitas reentrâncias, resultando em uma maior área de contato entre os materiais, facilitando e aumentando a dissociação dos éxcitons nas interfaces doador/aceitador. Isso permite a fabricação de filmes mais espessos, em relação à heterojunção em bicamada, o que possibilita maior absorção da luz. [39]

Um fator importante na fabricação dos dispositivos é o controle da morfologia dos materiais doador e aceitador de elétrons. Isso porque uma mistura não ideal desses materiais pode produzir perdas por processos de recombinação de cargas, comprometendo a eficiência de conversão de potência do dispositivo. Além disso, o transporte de cargas eficiente desses dispositivos depende da formação de um caminho condutor de elétrons e outro de buracos até os seus respectivos eletrodos.

\subsection{4}

\section{Breve relato da evolução dos dispositivos fotovoltaicos orgânicos}

Visto que já foram discutidas diversas características, tipos de estruturas, princípios de funcionamento e principais parâmetros utilizados na caracterização de um dispositivo fotovoltaico orgânico, irei relatar de forma muito sucinta a evolução temporal destes dispositivos, partindo da sua primeira estrutura fabricada em 1986 até a atualidade, onde o grafeno e substratos flexíveis têm apresentado papéis importantes para desenvolver dispositivos cada vez mais eficientes e flexíveis.

Em 1986, C.W. Tang [2] relatou os primeiros resultados sobre eficiência em dispositivo fotovoltaico orgânico, em torno de $1 \%$. Desde então, a eficiência de conversão de potência dos dispositivos fotovoltaicos orgânicos vem melhorando constantemente, 
através da utilização de novas técnicas e métodos, incluindo o uso de heterojunções [42], de camada de bloqueio de éxcitons (EBL) [43], do uso de dopantes orgânicos e inorgânicos [44], entre outros.

Além disso, modificações na estrutura das camadas doadoras e aceitadoras de elétrons têm sido feitas para maximizar as propriedades optoeletrônica dos dispositivos fotovoltaicos. Neste sentido, W. Zhao e colaboradores [10] fabricaram diferentes dispositivos, seguindo sempre a estrutura do tipo ITO/ZnO/camada ativa/ $\mathrm{MoO}_{3} / \mathrm{Al}$, alternando apenas a camada ativa, a qual foi otimizada a partir de seus percursores (PBTB-T e ITIC). Observa-se também nesta estrutura, a ausência de camadas derivadas do fulereno, o qual está sendo descrito como uma nova geração de dispositivos fotovoltaicos orgânicos (free-fullerene OPV). [10, 45]

A Tabela 1, apresentada por W. Zhao e colaboradores [10], mostra as distintas combinações de camadas ativas empregadas na estrutura ITO/ZnO/camada ativa/ $\mathrm{MoO}_{3} / \mathrm{Al}$, juntamente com diversos parâmetros de caracterização dos dispositivos fotovoltaicos orgânicos, entre eles o PCE, que corresponde à eficiência de conversão de potência.

Tabela 1: Principais parâmetros de caracterização de dispositivos fotovoltaicos orgânicos para distintas camadas ativas empregadas na estrutura ITO/ZnO/camada ativa/ $\mathrm{MoO}_{3} / \mathrm{Al}$. Adaptado de [10]

\begin{tabular}{|c|c|c|c|c|}
\hline \multirow{3}{*}{ Camada ativa } & VOC & $J_{s c}$ & \multirow{3}{*}{$\mathrm{FF}$} & \multirow[t]{2}{*}{ PCE } \\
\hline & & & & \\
\hline & {$[\mathrm{V}]$} & {$\left[\mathrm{mA} / \mathrm{cm}^{2}\right]$} & & [\%] \\
\hline PBDB-T:ITIC & $0.90(0.90 \pm 0.01)$ & $17.03(16.53 \pm 0.35)$ & $0.721(0.707 \pm 0.01)$ & $11.05(10.61 \pm 0.25)$ \\
\hline PBDB-T-SF:PC ${ }_{71} \mathrm{BM}$ & $0.96(0.96 \pm 0.01)$ & $14.00(13.62 \pm 0.28)$ & $0.661(0.639 \pm 0.02)$ & $8.89(8.42 \pm 0.23)$ \\
\hline PBDB-T-SF:IT-4F & $0.88(0.86 \pm 0.02)$ & $20.50(20.38 \pm 0.63)$ & $0.719(0.702 \pm 0.02)$ & $12.97(12.46 \pm 0.27)$ \\
\hline PBDB-T-SF:IT-4F a) & 0.88 & 20.88 & 0.713 & 13.10 \\
\hline PBDB-T-SF:IT-4F b) & 0.86 & 18.93 & 0.682 & 11.10 \\
\hline
\end{tabular}

a) e b) Os dados experimentais coletados foram reportados pelo Instituto Nacional de Metrologia da China (NIM) 
Mesmo apresentando essa alta eficiência, devido à otimização da camada ativa, estes dispositivos ainda poderiam ser melhorados, como por exemplo, através do uso de eletrodos mais eficientes, tal como o grafeno, o qual possui transmitância ótica em torno de $97 \%$ e excelentes propriedades condutoras, ou aprimoradas para o uso em aplicações em superfícies irregulares, através do uso de substratos flexíveis.

Diversos trabalhos têm sido relatados, apresentando resultados promissores, sobre o uso grafeno como eletrodo condutor transparente em combinação com substratos flexíveis e transparentes. Cita-se, por exemplo, a fabricação de dispositivos fotovoltaicos orgânicos flexíveis, utilizando substratos polimérico à base de poliimida (PI), multicamadas de grafeno crescido pelo método CVD dopadas como ânodo e P3HT:PCBM [(poly(3-hexylthiophene) e [6,6]-phenyl-C61-butyric acidmethylester)] como camada ativa $[21,46]$. Os resultados mostrados na Figura 15 indicam um dispositivo fotovoltaico orgânico com uma eficiência de conversão de potência (PCE) em torno de $3,2 \%$ e excelente estabilidade à flexão mecânica, a qual pode ser comprovada pela sutil diminuição dos valores de $\mathrm{V}_{\mathrm{OC}}, \mathrm{J}_{\mathrm{SC}}, \mathrm{FF}$ e $\eta$ (PCE), conforme pode ser observado na Figura 15 (c).
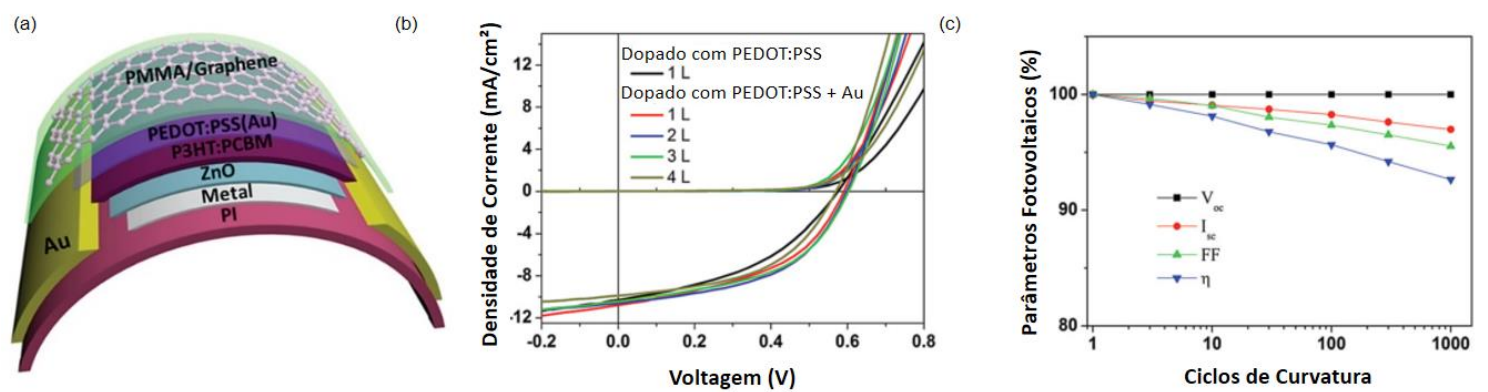

Figura 15: (a) Diagrama esquemático da estrutura do dispositivo fotovoltaico orgânico utilizando PI como substrato flexível; (b) Curvas características de $\mathrm{J} \times \mathrm{V}$ para diferentes números de camadas de grafeno usado como anodo com diferentes dopagens; (c) Valores de $\mathrm{V}_{\mathrm{OC}}$, $\mathrm{J}_{\mathrm{SC}}$, FF e $\eta$ (PCE) em função dos ciclos de flexão. Adaptado de [21].

Ainda explorando a potencialidade de dispositivos flexíveis, Kim, H. e colaboradores [22] desenvolveram em 2014, um dispositivo fotovoltaico orgânico flexível e altamente eficiente, com substrato de PET, multicamadas de grafeno como ânodo e camada ativa de PCDTBT:PC $70 \mathrm{BM}$ [poly[N-900-hepta-decanyl-2,7-carbazolealt-5,5-(40,70-di-2-thienyl-20,10,30-benzothiadiazole)] e [6,6]-phenyl-C71-butyric 
acidmethylester)]. Este dispositivo apresentou uma eficiência de conversão de potência de $4,33 \%$.

$\mathrm{Na}$ Figura 16 observa-se o diagrama esquemático do dispositivo descrito previamente, destacando a presença do substrato de PET e grafeno, bem como as curvas $\mathrm{J} \times \mathrm{V}$ para diferentes camadas de grafeno usadas no dispositivo.
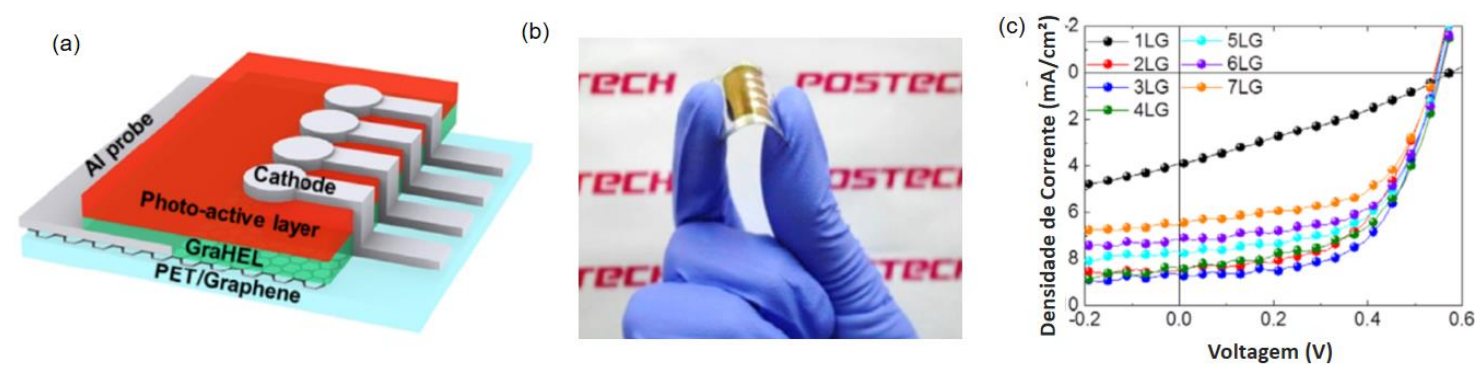

Figura 16: (a) Diagrama esquemático da estrutura do OPV utilizando PET como substrato flexível; (b) Imagem do dispositivo fotovoltaico orgânico sendo flexionado; (c) Curvas características de J×V para diferentes números de camadas de grafeno usado como anodo. Adaptado de [22].

Recentemente, um novo método de transferência de grafeno crescido pelo método CVD, baseado em PEDOT:PSS foi relatado [23]. A camada grafeno/PEDOT:PSS é diretamente utilizada sem o processo de remoção, simplificando o método de transferência e minimizando o problema de resíduos remanescentes em virtude dos métodos de transferência convencionais. Diante disso, foram construídos dispositivos fotovoltaicos orgânicos utilizando grafeno/PEDOT:PSS como eletrodo sobre substratos de vidro e PET, resultando em uma eficiência de conversão de potência de 5,5\% para uma estrutura convencional e 6,0 \% para uma estrutura invertida. Este trabalho nos motivou a utilizar uma blenda de EPDM-PAni para melhorar as propriedades do grafeno e simplificar o seu processo de transferência.

Em resumo, a Tabela 2 indica alguns trabalhos publicados, os quais utilizam grafeno e seus derivados como eletrodo transparente condutor em diferentes estruturas de dispositivos fotovoltaicos. 
Tabela 2: Resumo de alguns trabalhos que descrevem o uso do grafeno como eletrodo condutor e transparente aplicado aos dispositivos fotovoltaicos orgânicos.

\begin{tabular}{|c|c|c|c|c|}
\hline Eletrodo & $\mathbf{R}_{\mathrm{s}}, \mathbf{T}$ & Dispositivo & PCE (\%) & Ref. \\
\hline Grafeno & $\begin{array}{c}0.25 \mathrm{k} \Omega \mathrm{sq}^{-1} \\
T=92 \%\end{array}$ & $\begin{array}{l}\text { Quartzo/grafeno/PEDOT:PSS/CuPc: } \\
\qquad \mathrm{C}_{60} / \mathrm{BCP} / \mathrm{Ag}\end{array}$ & 0.85 & [14] \\
\hline Grafeno & $\begin{array}{c}3.5 \mathrm{k} \Omega \mathrm{sq}^{-1} \\
T=89 \%\end{array}$ & $\begin{array}{c}\text { PET/grafeno/PEDOT:PSS/CuPc:C } 60 / \\
\text { BCP/Al }\end{array}$ & 1.18 & [15] \\
\hline $\begin{array}{l}\text { Grafeno dop. } \\
\qquad \mathrm{AuCl}_{3}\end{array}$ & $\begin{array}{c}0.3 \mathrm{k} \Omega \mathrm{sq}^{-1} \\
T=91 \%\end{array}$ & $\begin{array}{l}\text { Quartzo/grafeno/PEDOT:PSS/CuPc/ } \\
\qquad \mathrm{C}_{60} / \mathrm{BCP} / \mathrm{Ag}\end{array}$ & 1.63 & [16] \\
\hline $\begin{array}{c}\text { Grafeno dop. } \\
\mathrm{HNO}_{3}\end{array}$ & $\begin{array}{c}0.08 \mathrm{k} \Omega \mathrm{sq}^{-1} \\
T=90 \%\end{array}$ & $\begin{array}{c}\text { Quartzo/grafeno/ } \mathrm{MoO}_{3}+\mathrm{PEDOT}: \mathrm{PSS} / \\
\text { P3HT:PCBM/LiF/Al }\end{array}$ & 2.5 & [17] \\
\hline $\begin{array}{l}\text { Grafeno dop. } \\
\qquad \mathrm{HNO}_{3}\end{array}$ & $\begin{array}{c}0.45 \mathrm{k} \Omega \mathrm{sq}^{-1} \\
T=90 \%\end{array}$ & $\begin{array}{c}\text { PET/grafeno/PEDOT:PSS/P3HT: } \\
\text { PCBM/Ca/Al }\end{array}$ & 2.54 & [18] \\
\hline $\begin{array}{l}\text { Grafeno/ } \\
\text { TCNQ }\end{array}$ & $\begin{array}{c}0.278 \mathrm{k} \Omega \mathrm{sq}^{-1} \\
T=92 \%\end{array}$ & $\begin{array}{c}\text { Vidro/grafeno/PEDOT:PSS/P3HT: } \\
\text { PCBM/Ca/Al }\end{array}$ & 2.58 & [19] \\
\hline Grafeno & $\begin{array}{c}0.3 \mathrm{k} \Omega \mathrm{sq}^{-1} \\
T=92 \%\end{array}$ & $\begin{array}{c}\text { Quartzo/grafeno/PEDOT:PEG(PC)/ } \\
\text { PEDOT:PSS/DBP/ C60/BCP/Ag }\end{array}$ & 2.9 & [20] \\
\hline $\begin{array}{l}\text { Grafeno dop. } \\
\text { PEDOT:PSS } \\
\quad+\mathrm{Au}\end{array}$ & $\begin{array}{c}0.09 \mathrm{k} \Omega \mathrm{sq}^{-1} \\
T=90 \%\end{array}$ & $\begin{array}{c}\mathrm{PI} / \mathrm{Cu} / \mathrm{P} 3 \mathrm{HT}: \mathrm{PCBM} / \mathrm{PEDOT}: \mathrm{PSS} / \\
\text { grafeno/PMMA }\end{array}$ & 3.17 & [21] \\
\hline $\begin{array}{l}\text { Grafeno dop. } \\
\qquad \mathrm{HNO}_{3}\end{array}$ & $\begin{array}{c}0.073 \mathrm{k} \Omega \mathrm{sq}^{-1} \\
T=92 \%\end{array}$ & $\begin{array}{c}\text { PET/grafeno/PEDOT:PSS:PFI/ } \\
\text { PCDTBT:PC } 70 \mathrm{BM} / \mathrm{LiF} / \mathrm{Al}\end{array}$ & 4.33 & [22] \\
\hline $\begin{array}{c}\text { Grafeno/ } \\
\text { PEDOT:PSS }\end{array}$ & $\begin{array}{c}0.08 \mathrm{k} \Omega \mathrm{sq}^{-1} \\
T=85 \%\end{array}$ & $\begin{array}{c}\text { Vidro/grafeno/PEDOT:PSS/PEIE/ } \\
\text { PTB7:PC }{ }_{71} \mathrm{BM} / \mathrm{MoO}_{3} / \mathrm{Al}\end{array}$ & 6.0 & [23] \\
\hline
\end{tabular}

\section{3}

\section{Grafeno como eletrodo condutor transparente}

Os eletrodos condutores transparentes são componentes essenciais para diversos dispositivos optoeletrônicos, em especial para os dispositivos fotovoltaicos orgânicos. Atualmente, não existem muitos tipos de eletrodos condutores transparentes que possam ser sintetizados em larga escala e de forma barata. No mercado estão disponíveis filmes finos de óxidos condutores transparentes [ITO, óxido de estanho dopado com flúor 
(FTO), óxido de zinco ( $\mathrm{ZnO}$ ), entre outros], nanopartículas metálicas, nanotubos de carbono, sendo que o mais utilizado é o ITO.

Como o custo do ITO está cada vez mais alto, devido à escassez do índio, a procura por um novo material mecânica e quimicamente resistente é imprescindível. O grafeno, uma das formas alotrópicas do carbono em formato bidimensional, tem sido recentemente proposto como uma alternativa ao ITO, por causa das suas propriedades óticas e eletrônicas peculiares, tais como alta transparência ótica, alta mobilidade de portadores de carga e baixa resistência elétrica de contato com materiais orgânicos, tornando-o um material ideal para ser utilizado como eletrodo condutor transparente [11, 30, 33, 47].

Devido às suas propriedades físicas, o grafeno tem sido proposto para aplicações em diferentes campos da ciência e tecnologia, como por exemplo, telas sensíveis ao toque, sensores, transistores, células solares, etc. Inclui-se dentre estas possíveis utilizações a área da Eletrônica Orgânica, principalmente no que tange aos dispositivos fotovoltaicos orgânicos, onde o grafeno pode atuar como um material chave para a produção de eletrodos de alta performance.

Como parte essencial de um dispositivo fotovoltaico orgânico, o seu eletrodo deve ter alta transparência $(>80 \%)$, baixa resistência de folha $\left(<100 \Omega \mathrm{sq}^{-1}\right)$, função trabalho adequada $(4,5-5,2 \mathrm{eV})$ e baixo custo de preparação, resultando em um eletrodo condutor e transparente simultaneamente [12, 30,47]. Como já mencionado, atualmente o ITO desempenha um papel dominante, sendo o padrão de mercado para a maioria das aplicações. O ITO possui transmitância ótica acima de 90\%, resistência de folha tão baixa quanto $(10-30) \Omega \mathrm{sq}^{-1}$ em vidro e $(60-300) \Omega \mathrm{sq}^{-1}$ em substratos plásticos e possui função trabalho de $\sim 4,8 \mathrm{eV}$ [47].

Em 2010, Bae, S. e colaboradores [24] descreveram os resultados sobre a síntese de filmes de grafeno crescidos pelo método CVD sobre largas folhas de cobre, sendo transferidos também para grandes áreas, através do método conhecido como roll-to-roll. Nesta metodologia, o grafeno adere ao polímero durante um processo térmico ao passar através de rolos, os quais promovem o contato mecânico entre ambos. Na sequência, o metal é corroído e tem-se o polímero/grafeno como produto final.

Conforme pode ser observado na Figura 17, os filmes de grafeno apresentaram resistência de folha e transmitância ótica de $\sim 275 \Omega \Omega^{-1}$ e 97,4 \% (em $550 \mathrm{~nm}$ ) para uma única camada e $10 \Omega \mathrm{sq}^{-1}$ e $90 \%$ para quatro camadas de grafeno dopados com ácido nítrico $\left(\mathrm{HNO}_{3}\right)$, respectivamente [24]. Este foi o primeiro método relatado sobre a produção de grafeno em larga escala com um rendimento superior aos filmes de ITO. 

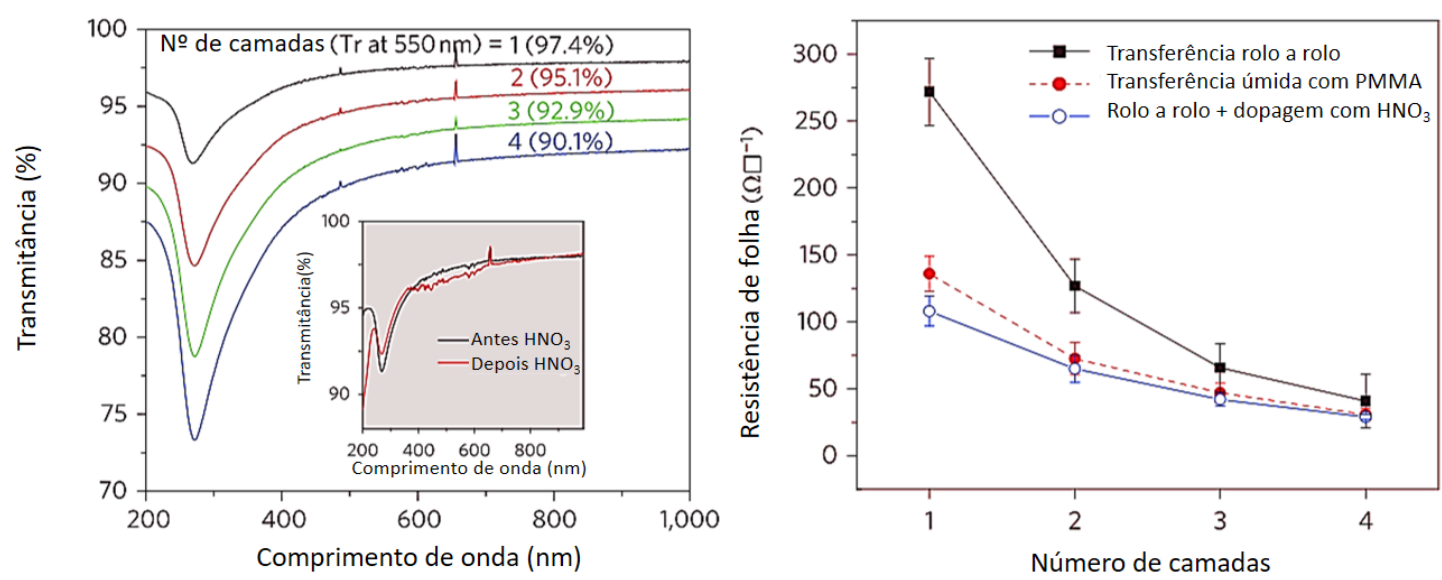

Figura 17: (a) Transmitância ótica de uma a quatro camadas de grafeno sobre substratos de quartzo. Inserido na figura um gráfico da transmitância ótica antes e depois da dopagem do grafeno com ácido nítrico $\left(\mathrm{HNO}_{3}\right)$. (b) Resistência de folha em função do número de camadas de grafeno transferido pelo método roll-to-roll com e sem dopagem com $\mathrm{HNO}_{3}$ e pelo método tradicional usando PMMA. Adaptado de [24]

Desde então inúmeros trabalhos tem sido publicados, mostrando multicamadas de grafeno crescidas pelo método CVD com resistência de folha que variam de 250 a 350 $\Omega \mathrm{sq}^{-1}$ e transmitância ótica de 89 a $92 \%[14,15,20]$, e multicamadas dopadas com $\mathrm{HNO}_{3}$ $[17,18,22]$, cloreto de ouro $\left(\mathrm{AuCl}_{3}\right)[18,48]$, e poli(3,4-etilenodioxitiofeno): poli(sulfonato de estireno) (PEDOT:PSS) [21, 23], entre outros, com resistência de folha de 73 a $450 \Omega \mathrm{sq}^{-1}$ e transmitância ótica de 85 a $92 \%$.

\subsection{1 \\ Estrutura do grafeno}

A estrutura química do grafeno é composta por átomos de carbono ligados entre si com hibridização $\mathrm{sp}^{2}$ formando uma estrutura cristalina hexagonal bidimensional, como ilustra a Figura 18. Nesta estrutura, cada átomo de carbono tem quatro elétrons, onde três são ligados covalentemente formando um ângulo de $120^{\circ}$ entre si. O quarto elétron ocupa o orbital remanescente $p_{z}$, o qual é perpendicular ao plano do grafeno. Os três elétrons de valência ligados covalentemente formam os orbitais $\sigma$ e o quarto elétron que ocupa o orbital $p_{z}$ não se hibridiza dando origem ao orbital $\pi$. 

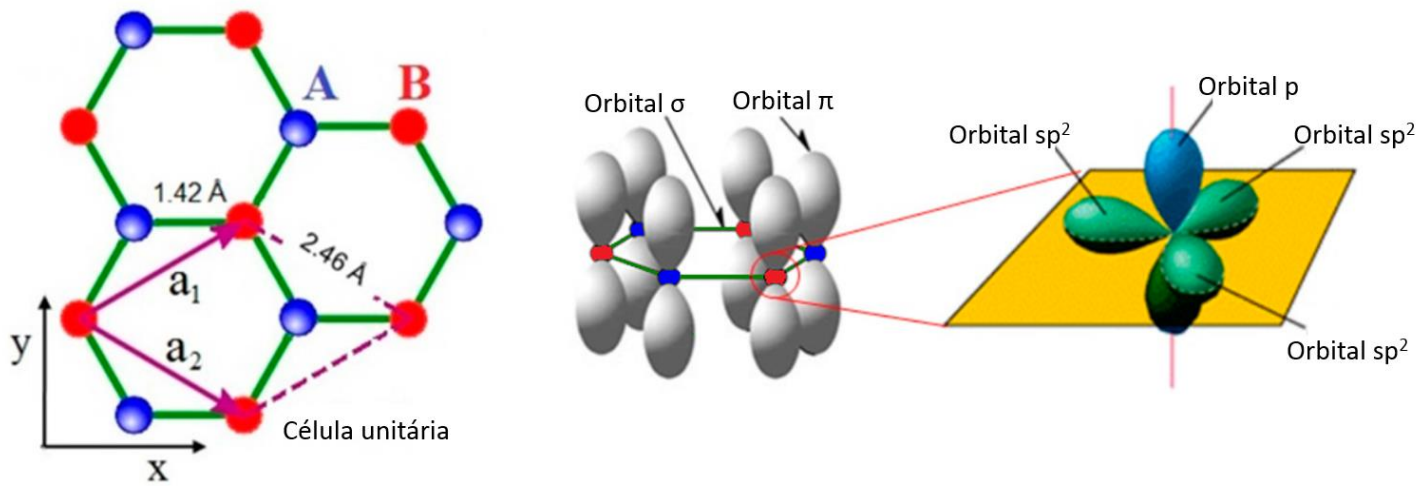

Figura 18: Estrutura cristalina do grafeno destacando a configuração dos seus orbitais eletrônicos responsáveis pela hibridização $\mathrm{sp}^{2}$. Adaptado de [49]

Os elétrons do orbital $\pi$ podem se deslocar pela rede do grafeno, por estarem mais fracamente ligados ao átomo, sendo os responsáveis pelo transporte de carga deste material.

\subsection{2 \\ Propriedades óticas, eletrônicas e estruturais do grafeno}

O transporte de carga no grafeno é majoritariamente de elétrons. Estes portadores de carga ao se propagarem apresentam uma relação linear entre sua energia e momento e, portanto, comportam-se como férmions de Dirac sem massa. Por conseguinte, o grafeno apresenta propriedades eletrônicas de gás 2D de partículas carregadas descritas pela equação de Dirac relativística. A partir desta interpretação, a estrutura de bandas de energia do grafeno, através do método tight-binding, é descrita por [30]:

$$
E(k)^{ \pm}= \pm \gamma \sqrt{1+4 \cos \left(k_{x} \frac{a \sqrt{3}}{2}\right) \cos \left(k_{y} \frac{a}{2}\right)+4 \cos ^{2}\left(k_{y} \frac{a}{2}\right)} \text { Equação } 8
$$

onde $\gamma$ é um número inteiro que depende matematicamente da integral de superposição e transferência da dispersão de energia e fisicamente está relacionado à energia entre os orbitais $\pi$ vizinhos de primeira ordem, admitindo valores entre 2.9 a $3.1 \mathrm{eV}$. Nesta mesma equação, temos que $a=\sqrt{3} a_{c c}$ (com a $\mathrm{a}_{c c}=1.42 \AA$, sendo esta a distância entre os carbonos da rede) e $k_{x}$ e $k_{y}$ são os pontos da rede recíproca. A Figura 19 (a) mostra a relação de dispersão da Energia $E_{k}$ para os diferentes pontos da rede recíproca $\left(k_{x}\right.$ e $\left.k_{y}\right)$. 
a)

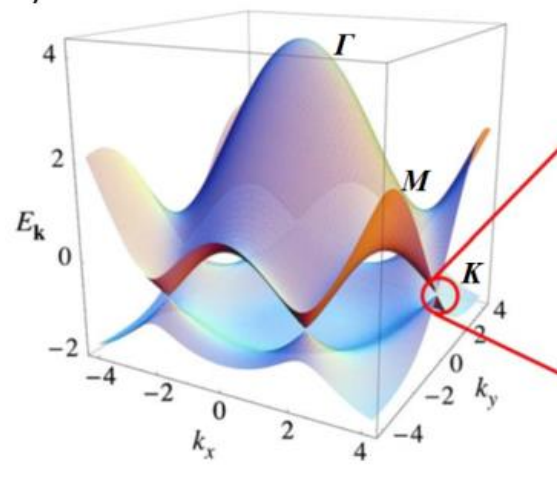

b)

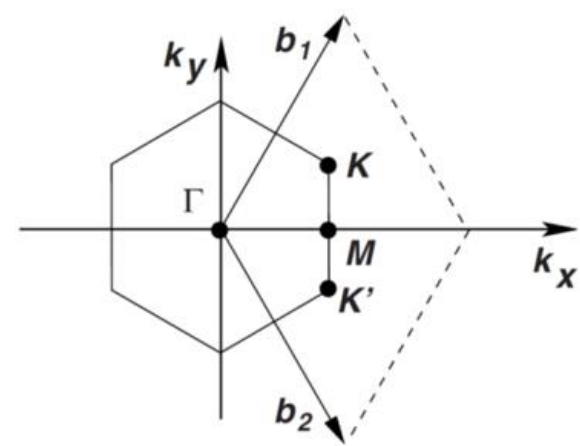

Figura 19: (a) Curva tridimensional da dispersão de energia para os elétrons $\pi$ e $\pi^{*}$ do grafeno, via método tight-binding. A direita um aumento do comportamento linear da dispersão próximo ao ponto de Dirac. (b) Rede hexagonal do grafeno no espaço recíproco mostrando os pontos de alta simetria $\Gamma, M, K$ e $K^{\prime}$. [50]

A parte positiva do eixo $E_{k}$ representa a banda de condução $\pi^{*}$, enquanto que a parte negativa representa a banda de valência $\pi$. Essas bandas formam duas superfícies que se tocam nos pontos de alta simetria K e K' (representados também na Figura 19 (b), também conhecidos como pontos de Dirac. Nestes pontos a banda proibida (gap) de energia entre as bandas $\pi$ e $\pi^{*}$ é zero, o que ocasiona propriedades singulares para este material.

Fazendo uma expansão da Equação 1 para energias próximas ao nível de Fermi e com vetores de onda próximos aos pontos e K e K', temos:

$$
E(k)^{ \pm}= \pm \hbar v_{f} k
$$

onde a velocidade de Fermi $\left(v_{f}\right)$ é calculada por $v_{f}=\frac{3 \gamma a}{2 \hbar} \approx 10^{6} \mathrm{~m} / \mathrm{s}$.

Portanto, para este regime temos uma dispersão linear que se assemelha à dispersão para partículas relativísticas com massa de repouso nula, corroborando a interpretação teórica de que os elétrons no grafeno se comportam como férmions não massivos, obedecendo a equação de Dirac.

Esta compreensão dos elétrons atuando como férmions não massivos na estrutura do grafeno explica as propriedades eletrônicas únicas e intrigantes observadas experimentalmente, estimulando diversas aplicações para este material, inclusive devido a sua altíssima transmitância ótica, conforme será descrito seguir. 


\subsubsection{1}

\section{Transmitância ótica do grafeno}

A transmitância ótica $T(\omega)$, para uma luz com frequência $\omega$, incidida perpendicular a uma monocamada de grafeno, pode ser estimada a partir da sua condutância ótica $G(\omega)$, de tal forma que:

$$
T(\omega)=\left[1+\frac{2 \pi}{c} G(\omega)\right]^{-2}
$$

onde c é a velocidade da luz no vácuo. Para " $n$ ” folhas de grafeno, a condutividade ótica passa a ser descrita como múltiplos deste fator, logo $G(\omega)=n G_{1}(\omega)$, onde $G_{1}(\omega)$ é a condutividade ótica para uma única camada de grafeno.

Conforme descrito no item anterior, os elétrons no grafeno se comportam como férmions não massivos, obedecendo a equação de Dirac. Assim sendo, $\mathrm{G}_{1}(\omega)$ atinge o limite da condutância ótica universal $\mathrm{G}_{0}$, tal que $G_{0}=e^{2} / 4 \hbar$. Logo:

$$
T=\left(1+\frac{n \pi \alpha}{2}\right)^{-2} \approx 1-n \pi \alpha \approx 97,7 \%
$$

Equação 11

onde $\alpha=e^{2} / \hbar c=1 / 137$ é a constante de estrutura fina. Deste modo, a absorção para uma única folha de grafeno pode ser estimada como $A=1-T=\pi \alpha=2,3 \%$.

O grafeno reflete menos de $0,1 \%$ da luz incidente na região do visível. Assim, a absorção ótica de camadas de grafeno é linearmente proporcional ao número de camadas, sendo que cada camada absorve 2,3\% do espectro visível (faixa de 370 a $750 \mathrm{~nm}$ ), como mostra a Figura 20. [47, 51]

Experimentalmente, a transmitância ótica do grafeno obtida pelo método de esfoliação mecânica $(\mathrm{T}=97,7$ \%) [51], bem como pelo método CVD $(\mathrm{T}=97,4 \%$ \% [24] estão em excelente concordância com o resultado teórico mostrado na Figura 20. Nesta figura, os círculos azuis representam os dados experimentais obtidos, ao passo que a curva vermelha representa a transmitância esperada para férmions de Dirac bidimensionais e a verde representa o modelo teórico de absorção para uma folha de grafeno. 


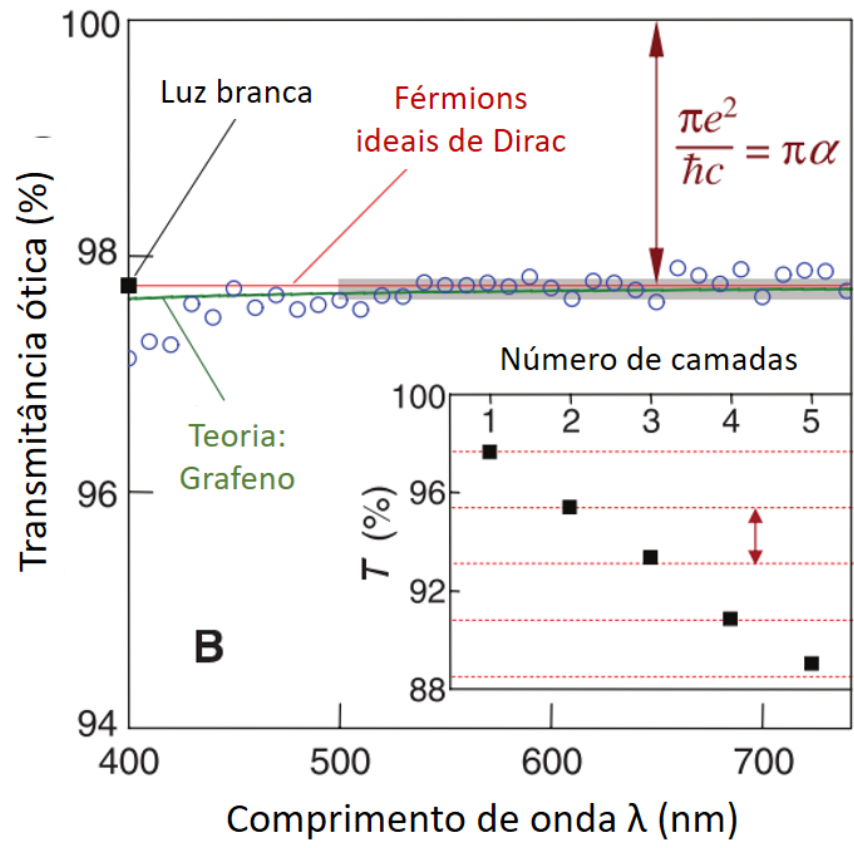

Figura 20: Transmitância ótica de uma monocamada de grafeno obtida pelo método de esfoliação mecânica. Inserido nesta figura, também se apresenta o gráfico da transmitância ótica em função do número de camadas de grafeno. Adaptado de [51].

Observa-se no gráfico inserido na Figura 20 que o decremento da transmitância ótica é linear à quantidade de folhas de grafeno, em concordância com o valor teórico de $2.3 \%$ de absorção ótica por folha.

\subsubsection{2}

\section{Resistência de folha do grafeno}

Em um filme fino, o qual é o caso de mono e poucas camadas de grafeno, a resistência de folha $\left(R_{S}\right)$ é descrita pela razão entre a resistividade elétrica $(\rho)$ e a espessura do filme (t), onde a resistividade é o inverso da condutividade elétrica $(\sigma)$. [30]. Dessa forma, a resistência elétrica $\mathrm{R}$ de um filme fino retangular de comprimento $\mathrm{L} \mathrm{e}$ largura $\mathrm{W}$ é dada por:

$$
R=\frac{\rho}{t} \times \frac{L}{W}=R_{s} \times \frac{L}{W}
$$

O termo L / W pode ser interpretado como o número de quadrados de lados L e W, sobrepostos. Assim, mesmo que $\mathrm{R}_{\mathrm{S}}$ tenha unidades de ohms (como R), é historicamente citado em ohms por quadrado ou do inglês, ohms per square, $\left(\Omega \mathrm{sq}^{-1}\right)$. 
Em geral, as propriedades físico-químicas do grafeno dependem fortemente de sua qualidade morfológica e cristalina, independentemente do método de síntese utilizado.

Além disso, o grafeno é muito susceptível aos efeitos de dopagens, os quais são capazes de modificar sua nanoestrutura. Nestes casos, a dopagem com moléculas orgânicas, por exemplo, atua como agente doador ou aceitador de carga, modificando a estrutura eletrônica do material. O grafeno pode ser quimicamente dopado com níveis de $\mathrm{N}_{\mathrm{i}}=10^{12} \mathrm{~cm}^{-2}$, mantendo a sua mobilidade de portadores de carga em torno de $\mu=10^{5}$ $\mathrm{cm}^{2} /(\mathrm{V} \mathrm{s})$ ou superior [47]. Com base nestes valores de $\mathrm{N}_{\mathrm{i}} \mathrm{e} \mu$, a resistência de folha do grafeno pode ser estimada por:

$$
R_{s}=\frac{1}{e \mu N_{i} N}=\frac{64,2}{N} \Omega
$$

onde $\mathrm{N}$ é o número de camadas de grafeno. [47]

Algumas técnicas experimentais possuem sensibilidade suficiente para determinar a presença e a concentração da dopagem existente, inclusive identificando o tipo da mesma. Dentre essas técnicas, a espectroscopia Raman, a qual foi explorada nesta tese, é descrita na sequência.

\subsubsection{3 \\ Modos vibracionais do grafeno}

Os modos vibracionais de qualquer material são consequências de suas propriedades químicas e estruturais e, portanto, as informações provenientes de seus modos são ferramentas importantes para distinguir e caracterizar o material. Para este tipo de análise, utilizamos a espectroscopia Raman, a qual é uma técnica de caracterização, em geral, não destrutiva, rápida e simples, a qual fornece informações estruturais, eletrônicas e vibracionais de distintos composto orgânico ou inorgânico, permitindo assim inclusive a sua identificação. Em especial, esta técnica é muito sensível para investigar modificações em nanoestruturas de carbono, e imprescindível para determinar a quantidade de camadas presentes e a presença de defeitos (dopagem, bordas, falhas estruturais, entre outros).

Quando uma luz monocromática com determinada frequência incide sobre um material, dois tipos de espalhamentos da luz podem ocorrer: elásticos e inelásticos. $\mathrm{O}$ espalhamento é elástico quando a luz incidente tem a mesma energia da luz espalhada 
(espalhamento Rayleigh). No espalhamento inelástico da luz, denominado efeito Raman, os fótons incidentes ganham ou perdem energia para o material. O fóton espalhado pode ter energia maior (processo Anti-Stokes) ou menor (processo Stokes) do que a energia do fóton incidente.

A diferença de energia entre a luz incidente e a espalhada relaciona-se com as propriedades vibracionais de cada material, ou seja, a frequência Raman pode ser relacionada diretamente às frequências das excitações elementares no material que deram origem ao espalhamento. Quando o fóton espalhado perde ou ganha energia para o material, ele cria ou absorve um quantum de algum tipo de excitação do material. Esse quantum de vibração da rede é chamado de fônon.

Na Figura 21 os três processos de espalhamento da luz que ocorrem entre os estado fundamental e o excitado são ilustrados. Nos espalhamentos Raman ocorre um aumento ou uma redução da energia do fóton espalhado $\mathrm{E}=\mathrm{h} v \pm \mathrm{h} v_{0}$, onde $\mathrm{h}$ é a constante de Planck, $v_{0}$ a frequência do fóton incidente e $v$ a frequência do fônon na rede cristalina. Desta forma, o processo Stokes acontece quando a frequência do fóton espalhado é menor que a frequência do fóton incidente e processo Anti-Stokes acontece quando a frequência do fóton espalhado é maior que a frequência do fóton incidente.

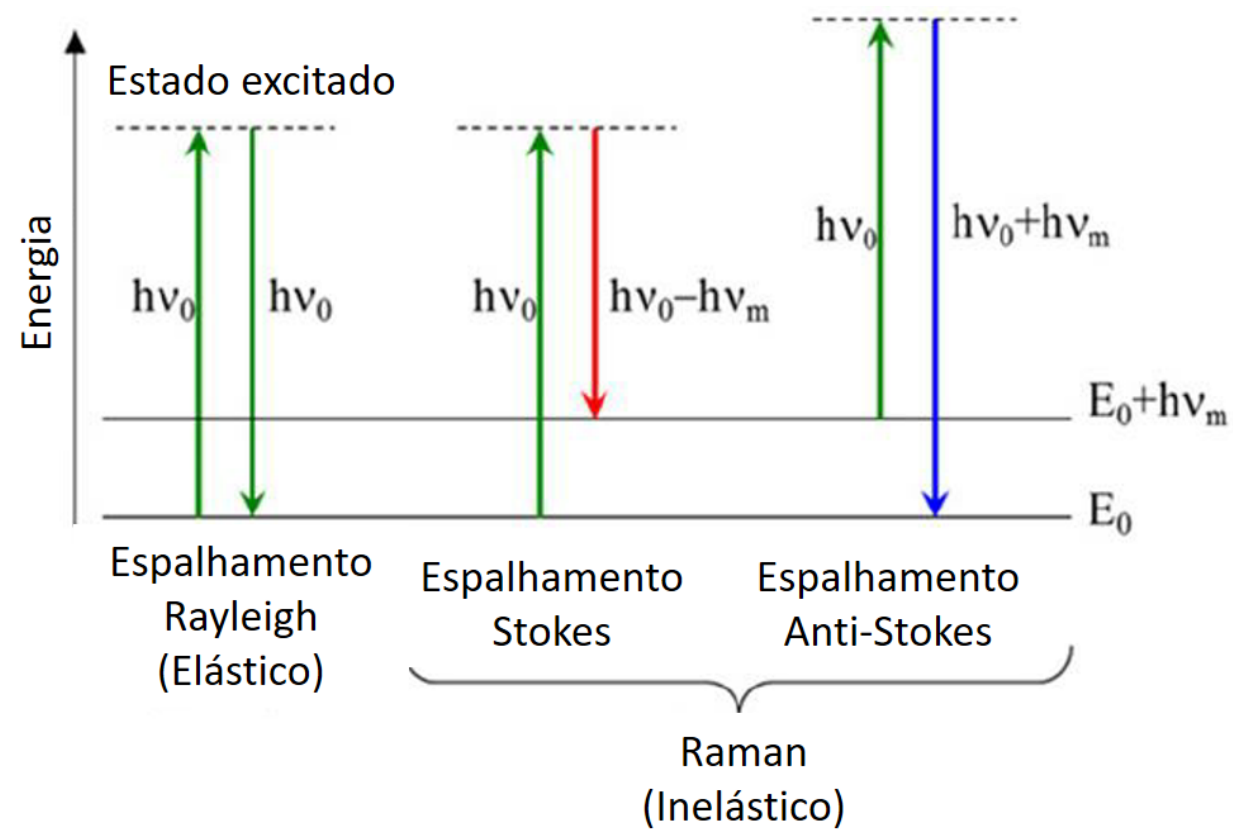

Figura 21: Esquema ilustrativo dos possíveis espalhamentos da luz com o material: elástico (Rayleigh) e inelástico (Raman). 
O conjunto de fônons típicos de cada material pode ser expresso através da relação de dispersão, onde suas frequências são representadas em função dos pontos de alta simetria $\Gamma, \mathrm{M}$ e K. Esta relação pode ser calculada resolvendo a equação de movimento para os deslocamentos tridimensionais $(\mathrm{x}, \mathrm{y}, \mathrm{z})$ do átomo. $\mathrm{O}$ grafeno possui dois átomos por célula unitária e cada um com três graus de liberdade, totalizando seis graus de liberdade. Estes graus de liberdade estão associados aos modos normais de vibração no grafeno. As seis curvas de dispersão podem ser visualizadas na Figura 22. Os modos são divididos em três modos óticos oTO, iTO e LO e três modos acústicos oTA, iTA e LA com valor nulo para frequência no ponto central da zona de Brilloüin ou ponto $\Gamma$. Nesta nomenclatura, "i" significa que os fônons podem se deslocar ao longo do plano da rede e "o" fora do plano, "T" pode realizar translações transversais e "L" longitudinais, "A" modo acústico e "O” modo ótico.

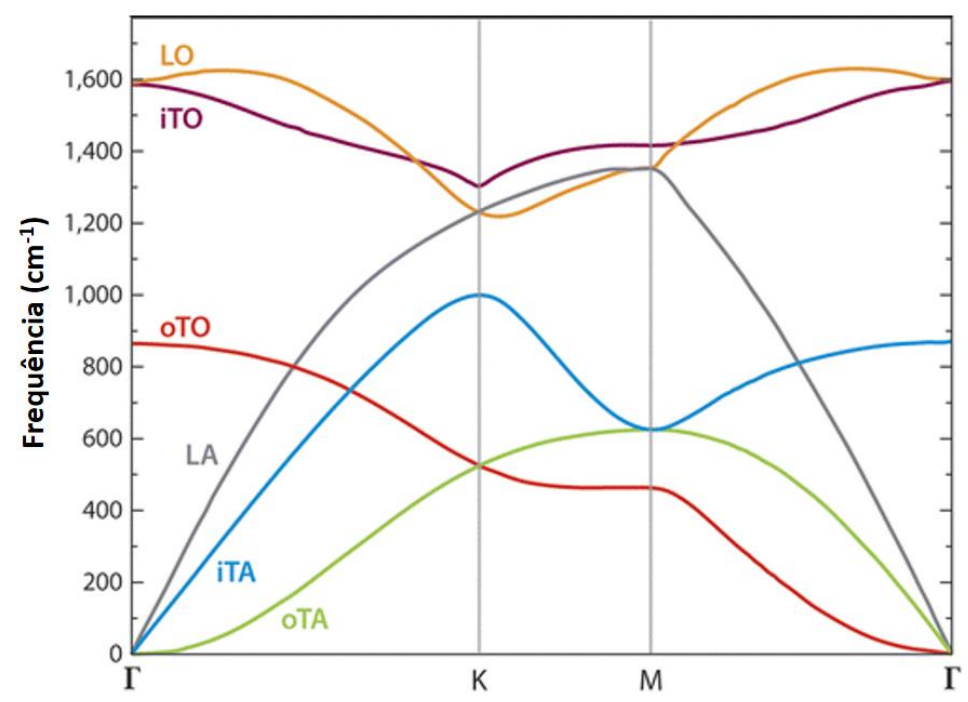

Figura 22: Diagrama de dispersão de fônons para o grafeno, calculado para as direções de alta simetria $\Gamma$, M e K. Adaptado de [52]

A Figura 23 mostra um espectro Raman típico do grafeno, destacando os seus modos vibracionais característicos. Os mais intensos são $G$ e G' (este último também chamado de 2D), localizados em 1582 e $2700 \mathrm{~cm}^{-1}$, respectivamente. Há também a existência de modos vibracionais correlacionados às concentrações de defeitos: banda $\mathrm{D}$, em torno de $1350 \mathrm{~cm}^{-1}$ e a banda D', em torno de $1620 \mathrm{~cm}^{-1}$ [53]. 


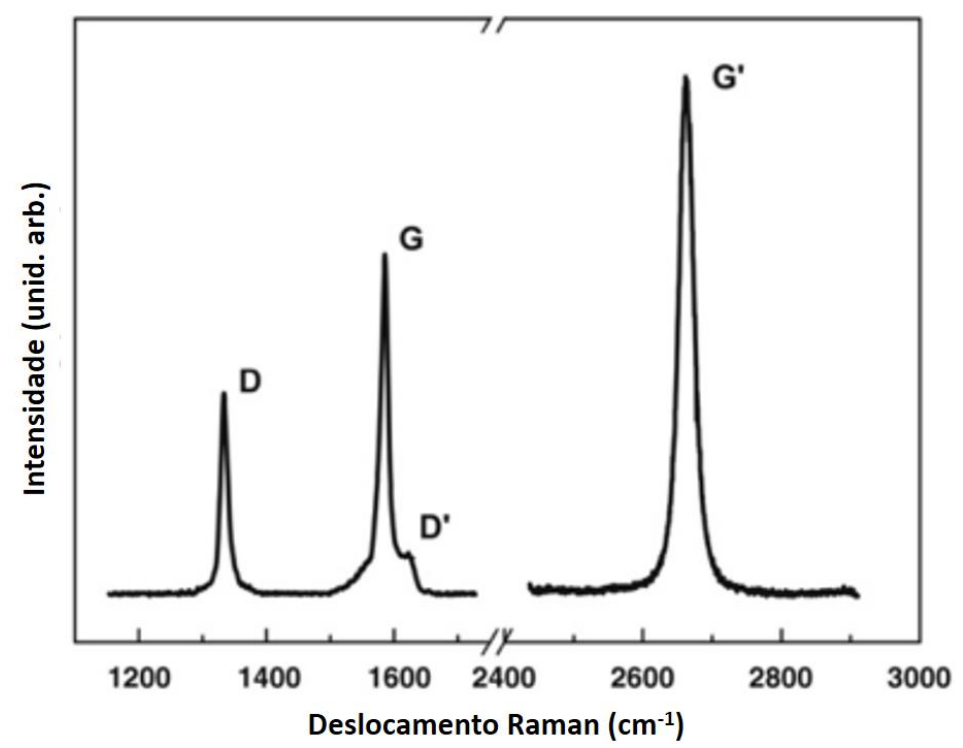

Figura 23: Espectro Raman típico de uma amostra de grafeno indicando os principais modos vibracionais presentes (bandas G, D, D’ e G') com energia de excitação do laser de 2,41 eV (514 nm). Adaptado de [53]

Todos estes modos vibracionais são gerados a partir de processos envolvendo um ou mais fônons, devido a presença de defeitos, intra-vales com o elétron espalhado para dentro do mesmo cone de Dirac e processos inter-vales onde um elétron pode ser espalhado para outro cone de Dirac equivalente, de K para K'. Na Figura 24 é representado os principais processos Raman que ocorrem no grafeno.

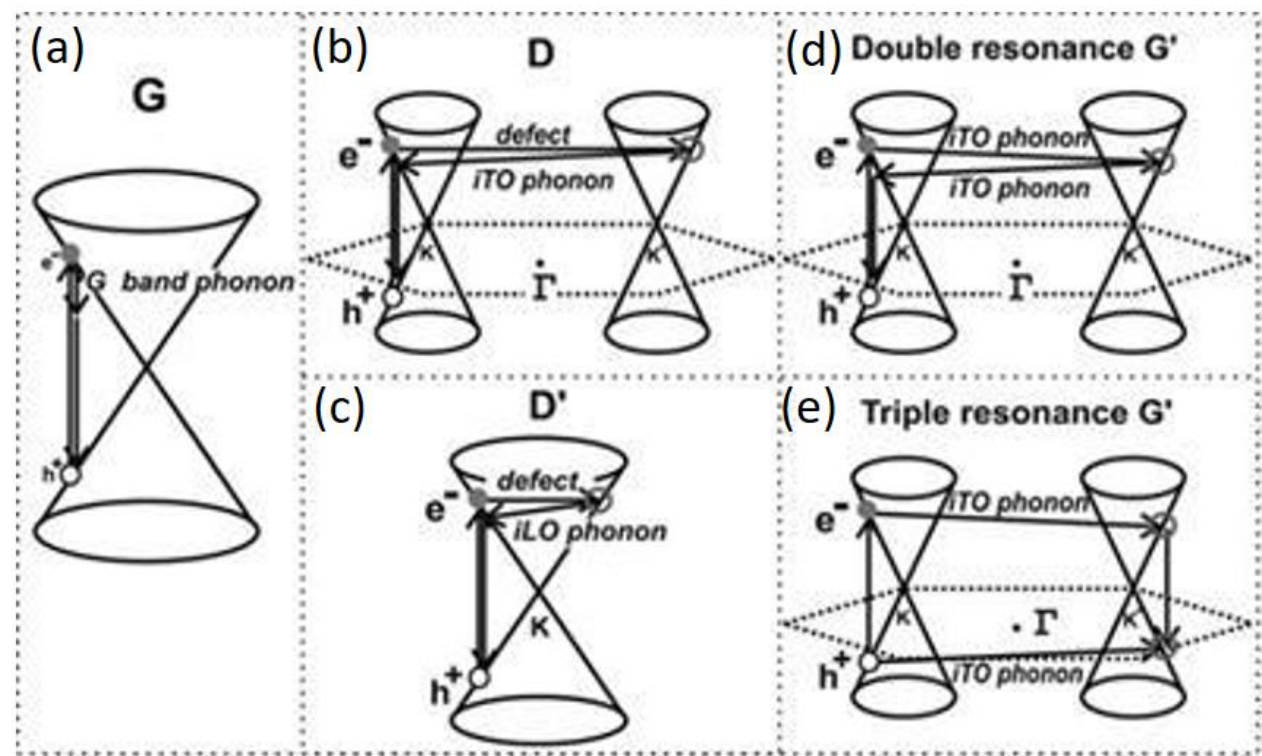

Figura 24: Principais processos Raman que ocorrem no grafeno: (a) de primeira ordem que dá origem à banda G; (b) e (c) de segunda ordem com um fônon dando origem à banda D (inter-vales) em (b) e à banda D' (intra-vales) em (c); (d) de segunda ordem com dois fônons dando origem à banda G'; (e) possível tripla ressonância dando origem à banda G'. [53] 
A banda $\mathrm{G}$ ocorre devido as vibrações de fônons duplamente degenerados (iTO e LO) no ponto de alta simetria $\Gamma$. Este modo vibracional é o único proveniente de um processo de espalhamento Raman de primeira ordem e está presente no espectro Raman de carbono com hibridização $\mathrm{sp}^{2}$. A banda $\mathrm{G}^{\prime}$ ocorre devido ao espalhamento de dois fônons iTO na vizinhança do ponto K. As bandas D e D' aparecem devido aos espalhamentos por um fônon iTO, sendo ativada na presença de defeitos. [53, 54]

A intensidade e largura da banda D são usadas para avaliar os tipos de defeitos e a razão das intensidades entre as bandas $\mathrm{D}$ e $\mathrm{G}$ fornece informações sobre a quantidade de defeitos existentes. Estes podem ser devidos às impurezas na rede do grafeno, vacâncias e contornos de grãos. A banda G' (2D) fornece informações sobre a quantidade de camadas atômicas existentes no material, podendo distinguir inclusive um grafeno mono de um bicamada. De fato, o formato dessa banda muda com diferentes camadas e a partir da largura de meia altura (FWHM, do inglês Full Width at half-maximum) do seu pico é possível determinar o número de camadas do grafeno. Na Figura 25 são mostrados três espectros Raman para uma, duas e três camadas de grafeno, onde pode-se evidenciar a mudança na banda G' conforme o número de camadas de grafeno.

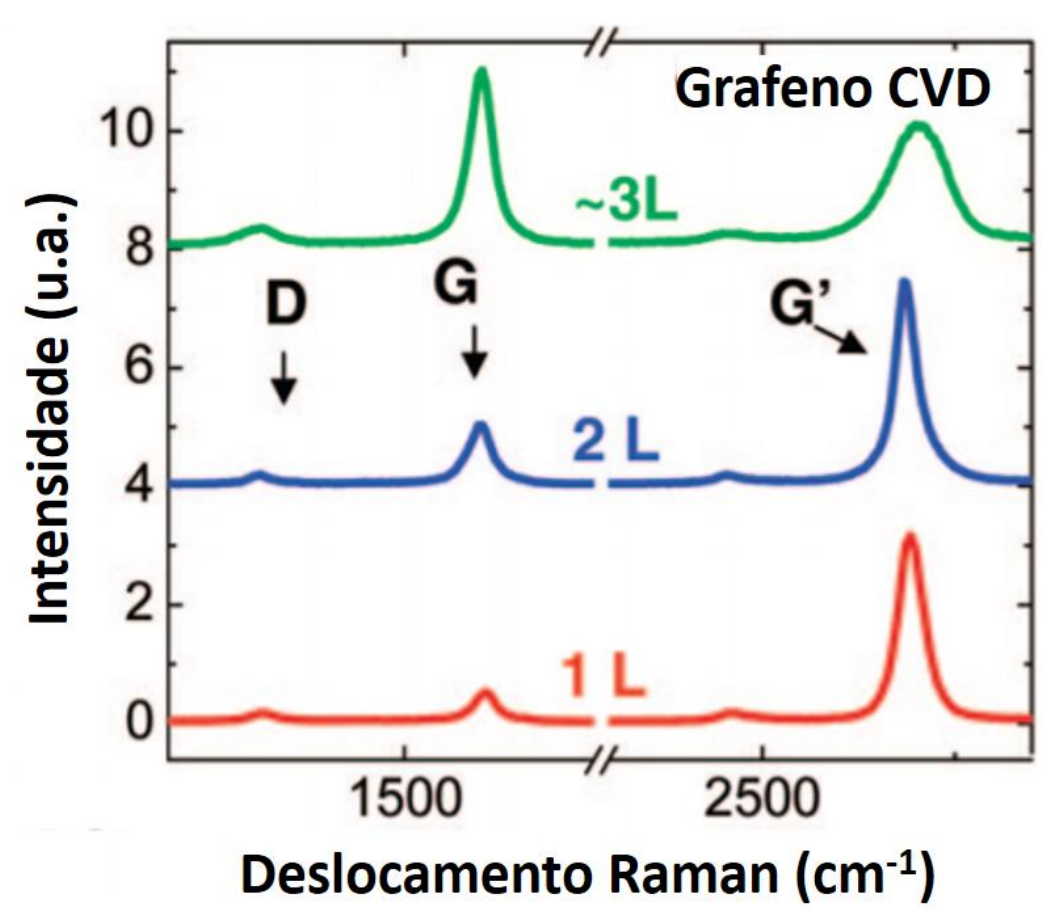

Figura 25: Espectros Raman mostrando a evolução da banda G' para uma (1L), duas (2L) e aproximadamente três (3L) camadas de grafeno para excitações de 532nm. Adaptado de [55] 


\subsection{3 \\ Métodos de síntese e produção de folhas de grafeno}

Existem diferentes métodos para a produção de grafeno. Os quatro principais métodos são descritos a seguir: (i) esfoliação [56], (ii) redução de óxido de grafeno (GO, do inglês graphene oxide) [57], (iii) decomposição térmica de carbeto de silício (SiC), e (iv) deposição química na fase de vapor (CVD, do inglês Chemical Vapour Deposition) [58].

(i) A técnica de esfoliação consiste na esfoliação mecânica de cristais de grafite utilizando uma fita adesiva, com objetivo de isolar folhas de grafeno. Este método é de fácil execução e precisa de poucos materiais para a produção, porém não é reprodutível em larga escala e produz pequenos flocos de grafeno com áreas micrométricas.

(ii) A obtenção de grafeno pelo método de redução de óxido de grafeno (GO) consiste na oxidação e esfoliação química de grafite em solventes. O GO é posteriormente reduzido produzindo folhas de grafeno dispersas tanto em solução, quanto em pó. Este método oferece um potencial para a produção em larga escala de grafeno, porém produz folhas de grafeno com defeitos estruturais e com radicais, alterando as propriedades eletrônicas originais do grafeno [58].

(iii) A síntese em larga escala de grafeno geralmente é baseada na decomposição térmica de carbeto de silício ( $\mathrm{SiC}$ ) [59] e no crescimento por CVD em substratos metálicos [58]. A formação de camadas de carbono com ligação $\mathrm{sp}^{2}$, sobre o substrato de $\mathrm{SiC}$ pode ser obtido por meio da sublimação de silício (Si) por aquecimento em temperaturas que variam entre 1000 e $1500{ }^{\circ} \mathrm{C} \mathrm{em}$ ultra alto vácuo e da decomposição térmica de hidrocarbonetos.

(iv) O método de crescimento de filmes de grafeno pela técnica de CVD tem recebido muita atenção pela alta qualidade dos filmes resultantes, bem como pela possibilidade de produção em grandes áreas. Por estes motivos e pela disponibilidade de infraestrutura que tínhamos, escolhemos este método de 
síntese para ser utilizado ao longo deste doutoramento. No próximo tópico serão discutidos maiores detalhes sobre esta técnica.

\subsubsection{1}

\section{Síntese por deposição química na fase de vapor (CVD)}

Nesta técnica o grafeno é crescido sobre folhas de um metal catalítico com espessura de alguns micrometros, o qual também atua como suporte mecânico para o filme produzido. Diferentes metais podem ser utilizados como catalisadores de carbono, incluindo níquel $(\mathrm{Ni})$, cobre $(\mathrm{Cu})$, paládio $(\mathrm{Pd})$ [58]. Dentre estes catalisadores, predomina-se o uso do cobre, devido a sua baixa solubilidade com o carbono. Esta propriedade pode ser constatada a partir do diagrama de fase binário do cobre-carbono $\left(\mathrm{Cu}_{1-\mathrm{x}} \mathrm{C}_{\mathrm{x}}\right)$ apresentado na Figura 26.

Como será detalhando a seguir, a síntese do grafeno é realizada em torno de 1000 ${ }^{\circ} \mathrm{C}$ e com folhas de cobre de altíssima pureza. Nesta temperatura o cobre (com poucas quantidades de carbono) permanece em estado sólido, fundindo para o líquido (L) apenas acima de $1085^{\circ} \mathrm{C}$. Dessa forma garantimos que não há solubilidade entre o cobre e o carbono.

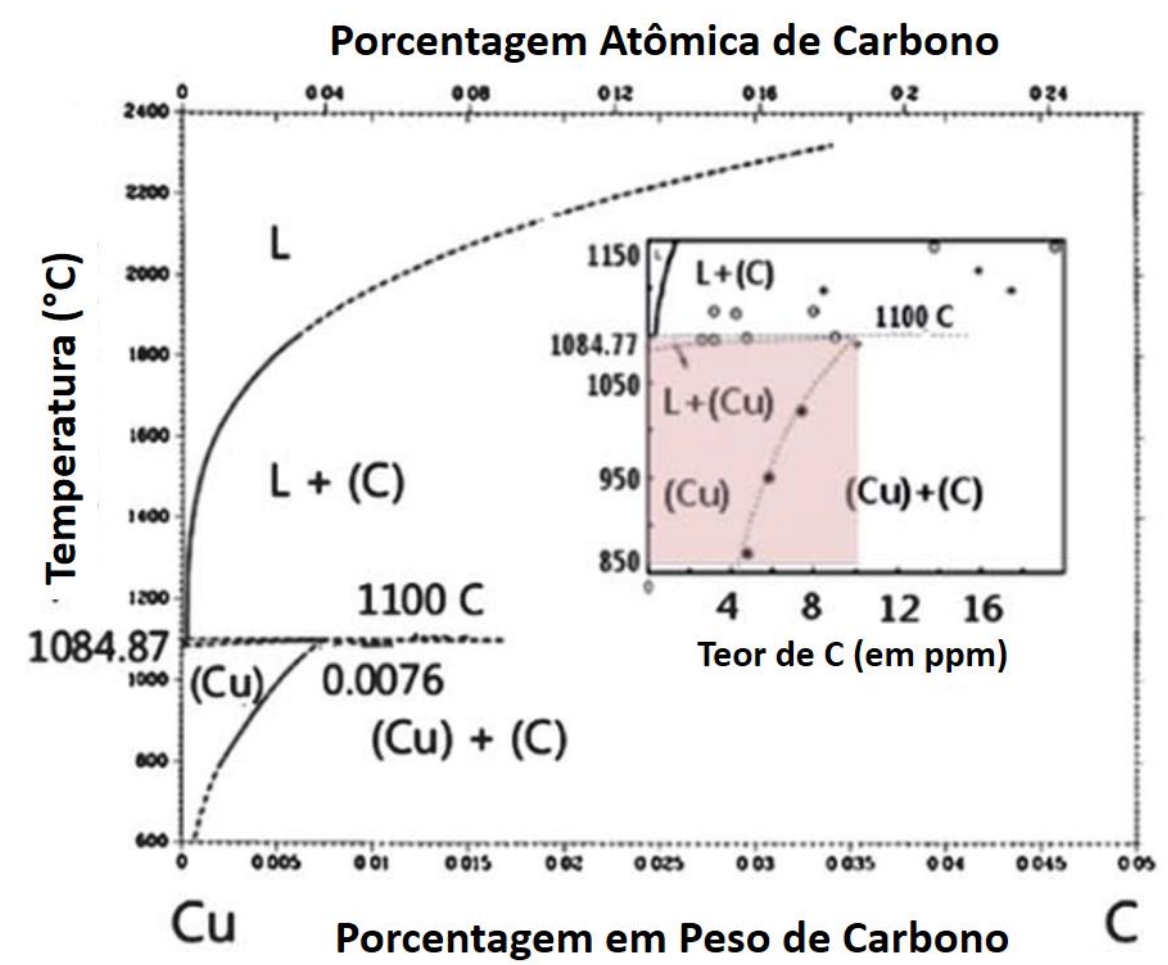

Figura 26: Diagrama de fase binário do cobre e do carbono. Em destaque na figura, a temperatura e a concentração de carbono de interesse para o crescimento de grafeno. Adaptado de [60] 
De forma genérica, os processos de produção por CVD seguem sempre uma rota bem estabelecida. Contudo, particularidades na produção, na infraestrutura e nos ajustes experimentais são fatores críticos e que precisam ser dimensionados para maximizar a qualidade dos filmes produzidos. Estes detalhes serão melhores descritos no Capítulo 3 Materiais e métodos. Neste momento o importante é compreender que a síntese de crescimento consiste nos seguintes passos:

ii) Inicialmente coloca-se um substrato metálico em um tubo de quartzo, o qual é introduzido em um forno com fluxo de argônio (Ar) e/ou hidrogênio $\left(\mathrm{H}_{2}\right)$ com temperatura crescente. Ao se utilizar o cobre, este é aquecido até 1000 ${ }^{\circ} \mathrm{C}$.

iii) Ao atingir a temperatura pretendida, o substrato é então submetido a um recozimento, o qual homogeneíza a superfície e afeta a solubilidade do carbono no metal-substrato [58]. Normalmente, a folha de cobre é recozida durante 30 min em uma atmosfera rica em hidrogênio. Este tratamento térmico resulta no crescimento dos grãos do cobre adequado para a fabricação de filmes de grafeno de maior qualidade, além de provocar a redução do óxido pré-existente do metal catalisador.

iv) Após 30 min de recozimento, uma fonte de carbono [em geral metano $\left(\mathrm{CH}_{4}\right)$ ou acetileno $\left(\mathrm{C}_{2} \mathrm{H}_{2}\right)$ ] é injetada com uma mistura de argônio com hidrogênio $\left(\mathrm{Ar} / \mathrm{H}_{2}\right)$. Nesta etapa, o carbono da fonte de gás se difunde na folha de cobre e forma pontos de nucleação de grafeno na superfície, o qual se estende até formar uma camada de grafeno continua.

v) O processo é finalizado resfriando o sistema até a temperatura ambiente com fluxo da mistura de $\mathrm{Ar} / \mathrm{H}_{2}$.

\subsection{4}

Transferência de grafeno para outros substratos

Após o processo de síntese do grafeno usando a técnica de CVD, a folha de grafeno mantém-se aderida ao substrato catalítico, o qual na maioria das vezes é um substrato de 
cobre. Com isso, faz-se necessário um método para separar a folha de grafeno do cobre. Este procedimento, chamado comumente de "transferência do grafeno", é um passo extremamente crítico, visto que um processo de transferência mal estabelecido ou mal executado resulta em uma folha de grafeno com inúmeros defeitos, os quais acarretam em um grande prejuízo às propriedades físico-químicas do material.

Um protocolo bem estabelecido de transferência de grafeno ocorre através do uso de uma camada de sacrifício. Neste caso, esta camada é comumente feita com o polímero PMMA (polimetil-metacrilato) [25, 55, 61, 62].

O processo consiste em recobrir o filme de grafeno com uma camada de PMMA para protegê-lo e sustentá-lo mecanicamente. Neste processo, a folha de grafeno fica sanduichada entre o substrato de cobre e a camada de PMMA. Em seguida corrói-se o metal com uma solução ácida $\left(\mathrm{HNO}_{3}, \mathrm{FeCl}_{3}\right.$, persulfato de amônio, entre outros) [58]. O filme de grafeno/PMMA restante do processo corrosivo é enxaguado com água deionizada (DI) e, sequencialmente, aderido ao novo substrato via contato mecânico.

Por fim, após o contato mecânico ter sido estabelecido entre o grafeno e o substrato desejado, o PMMA é finalmente removido. Para isso usa-se geralmente acetona. Após todo este processo, obtém-se uma camada de grafeno sobre o substrato escolhido, finalizando o processo de transferência.

Observa-se que este processo, por ser extremamente minucioso, pode acarretar inúmeros problemas, visto que se alguma etapa não for executada com perfeição teremos como resultado um filme de grafeno com inúmeros defeitos. Para contornar estes problemas que possam surgir, neste trabalho apresentamos um novo método de transferência, o qual simplifica o processo tradicional de transferência do grafeno, melhorando as propriedades óticas e elétricas do filme em comparação com o método tradicional. Neste processo de transferência desenvolvido durante este trabalho é utilizada uma blenda de EPDM-PAni, o qual será descrito no Capítulo 4 - Resultados e discussões.

\section{4 \\ Substratos poliméricos flexíveis}

Conforme discutido previamente, mesmo utilizando o grafeno ou óxidos inorgânicos como eletrodos condutores e transparentes (por exemplo o ITO), ainda ficamos dependente de um suporte mecânico adequado para promover a sustentação das camadas orgânicas do dispositivo fotovoltaico orgânico. 
Este suporte mecânico também precisa ser transparente para que a luz possa atravessá-lo e interagir com as camadas orgânicas do dispositivo fotovoltaico orgânico, sendo, portanto, comumente utilizado o vidro.

Atualmente, as placas de vidro são os substratos mais utilizados na fabricação de dispositivos orgânicos. Estas tornam-se flexíveis quando a sua espessura é da ordem ou inferior a centenas de micrômetros, mantendo suas propriedades de transparência acima de $90 \%$ na região do espectro visível, rugosidade menor que $1 \mathrm{~nm}$, baixo coeficiente de dilatação térmica na ordem de $4 \times 10^{-6}{ }^{\circ} \mathrm{C}^{-1}$ e resistência à maioria dos processos químicos, tal como a impermeabilidade à água e ao oxigênio. Porém apesar de manter todas as suas propriedades e tornar-se flexível, devido à sua baixa espessura, o vidro torna-se muito frágil e de difícil manipulação. [63]

Nesta tese, por exemplo, utilizamos substratos de vidro com espessura na ordem de $2 \mathrm{~mm}$, para não nos preocuparmos com a sua fragilidade de manipulação e principalmente pelo fato de também apresentarem propriedades compatíveis com a funcionalidade de um dispositivo fotovoltaico orgânico. Contudo, este enrijece o dispositivo, restringindo diversas aplicações para a Eletrônica Orgânica, como o recobrimento de superfícies curvas e até mesmo impossibilitando a integração com sistemas biológicos.

Como forma de contornar estas restrições de aplicabilidade, a Eletrônica Orgânica está direcionando seu interesse na fabricação de dispositivos mais eficientes e mecanicamente flexíveis, a partir do uso de substratos poliméricos. Os materiais poliméricos são produzidos a partir de um processo químico conhecido como polimerização, o qual é responsável por unir quimicamente os monômeros percursores. No entanto, os substratos poliméricos possuem algumas desvantagens, em relação aos substratos convencionais, tal como baixa estabilidade térmica, além de alguns serem permeáveis à água e ao oxigênio, podendo ocasionar processos de degradação indesejáveis ao dispositivo.

Por outro lado, os substratos fabricados a partir de materiais poliméricos são de fácil processabilidade e de baixo custo de produção, podendo até mesmo ser produzidos a partir de materiais recicláveis e biocompatíveis. [64]

Como exemplo de material polimérico utilizado para a fabricação de substratos flexíveis, podemos citar o politereftalato de etileno (PET), o qual é oticamente transparente, possui excelentes propriedades mecânicas e é praticamente insolúvel em água. Este material é classificado como um termoplástico, ou seja, não sofre alterações na sua estrutura durante o processo de aquecimento e, portanto, podem ser novamente 
fundidos após o resfriamento. Essa propriedade permite que este material seja reciclável, aumentando o interesse do seu uso.

\subsection{1 \\ Exemplo de comportamento mecânico e optoeletrônico desejável para aplicações em dispositivos fotovoltaicos orgânicos}

Em 2012, M. Kaltenbrunner e colaboradores [65] desenvolveram um dispositivo fotovoltaico orgânico extremamente fino e muito flexível utilizando substrato de PET com $1.4 \mu \mathrm{m}$ de espessura, resultando em um dispositivo com espessura inferior a $2 \mu \mathrm{m}$, conforme pode ser observado na Figura 27.

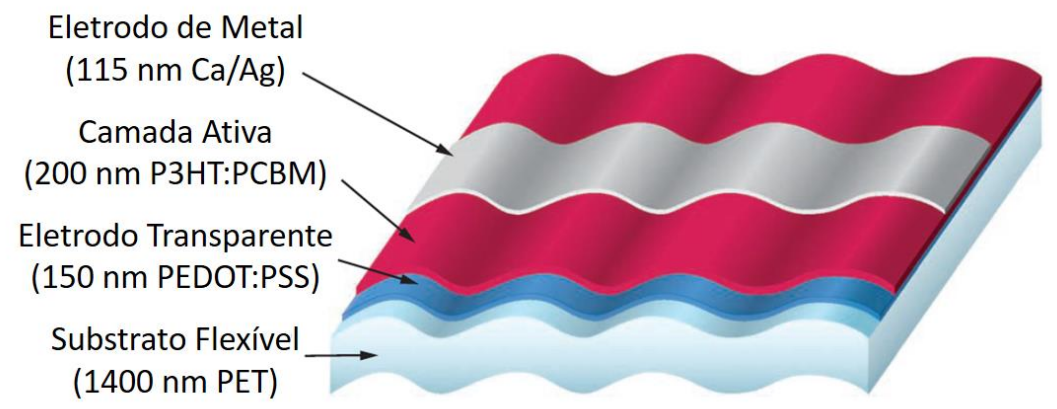

Figura 27: Estrutura de fabricação do dispositivo fotovoltaico orgânico, destacando as diferentes camadas e suas respectivas espessuras. Adaptado de [65]

Neste trabalho foram avaliadas as principais propriedades optoeletrônicas do dispositivo fotovoltaico orgânico mostrado acima, quando este é submetido à ciclos de compressão e extensão. Para isso, o dispositivo foi fixado em uma estrutura móvel sobre um material elastômero, permitindo deslocamento de $\mathrm{L}_{0}$ até $\mathrm{L}$, resultando em uma compressão unidimensional conforme ilustra a Figura 28. Neste diagrama esquemático, observa-se que é mantido os contatos do ânodo e catodo ligados, permitindo assim caracterizações elétricas durantes os ciclos de compressão e extensão do dispositivo. 


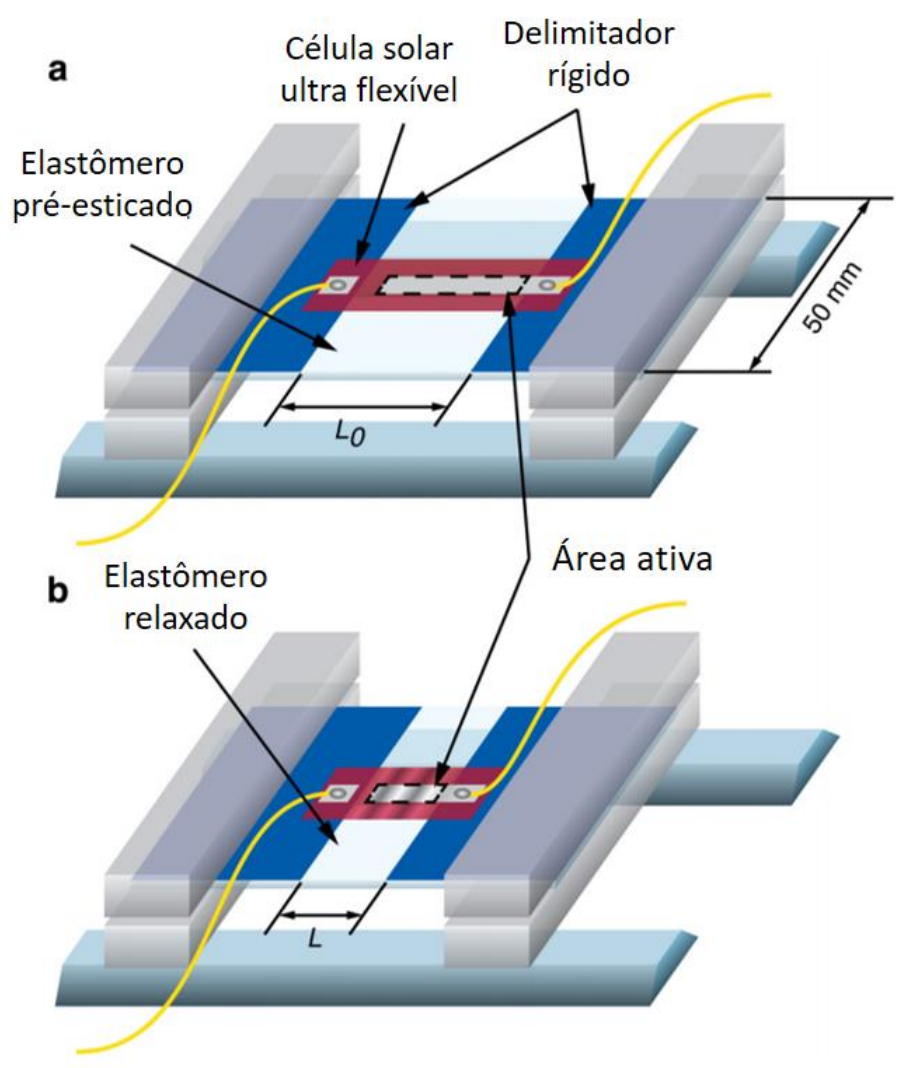

\section{C}
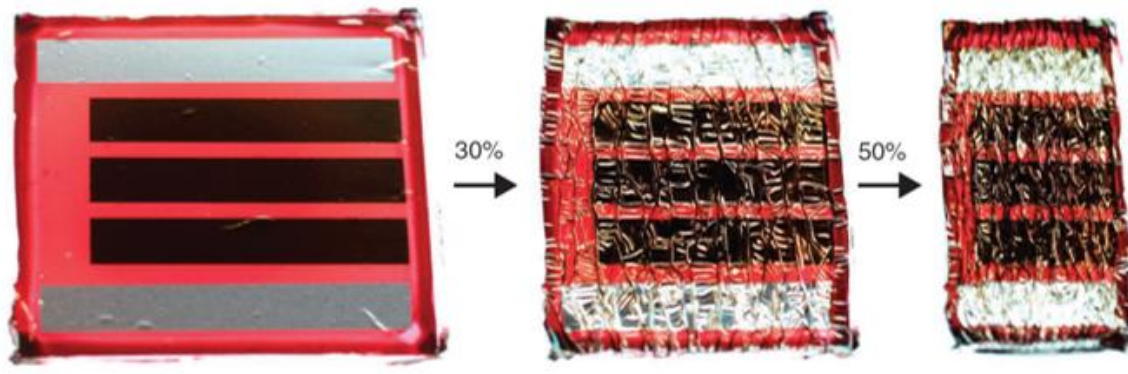

Figura 28: Diagrama esquemático do aparato usado para aplicar testes de compressão e extensão no dispositivo fotovoltaico orgânico, sendo (a) o momento de extensão e (b) de compressão; (c) Variação da morfologia do OPV depois da compressão em 30 e 50\% de sua área. Adaptado de [65]

A Figura 29 mostra os resultados para tensão de circuito aberto ( $\mathrm{V}_{\text {OC }}$ ), densidade de corrente de curto circuito $\left(\mathrm{J}_{\mathrm{SC}}\right)$, fator de preenchimento $(\mathrm{FF})$ e a eficiência de conversão de potência (PCE), obtidos após cada ciclo de compressão/extensão realizado. 


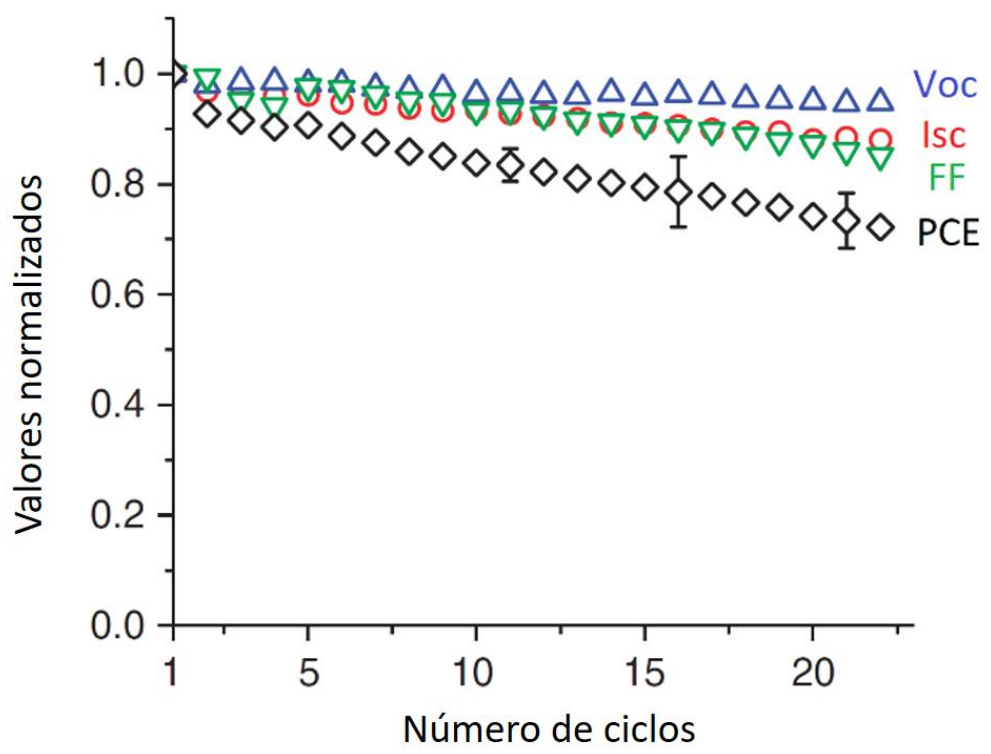

Figura 29: Medidas de $\mathrm{V}_{\mathrm{OC}}, \mathrm{J}_{\mathrm{SC}}$, FF e PCE em relação a quantidade de ciclos de compressão e extensão aplicado ao dispositivo. Adaptado de [65]

Neste momento, o importante é destacar que o uso de substratos poliméricos, quando submetidos à extremas deformações mecânicas, tem gerado pequenas variações em suas propriedades optoeletrônicas. Isso indica as vantagens do uso de substratos poliméricos flexíveis em dispositivos orgânicos, mesmo que esta área ainda necessite de intensas investigações para melhorar as rotas de sínteses e principalmente a otimização do uso desses substratos nos dispositivos fotovoltaicos orgânicos.

Ao longo desta tese foram utilizados três tipos de substratos poliméricos capazes de atuarem como substratos flexíveis e transparentes: o PVA, o PVC e a celulose bacteriana (BC) modificada com PVC, os quais serão melhores descritos no próximo capítulo. 


\section{3 \\ Materiais e métodos}

Neste capítulo serão apresentadas as principais etapas de crescimento de grafeno, síntese da blenda de EPDM-PAni e os processos de transferência do grafeno. Na sequência são descritos os materiais poliméricos que foram utilizados como substratos flexíveis. Ainda neste capítulo será descrito a fabricação dos dispositivos fotovoltaicos orgânicos, na qual serão apresentadas as técnicas de deposição e as infraestruturas que foram utilizadas durante este trabalho, seguido da deposição de ITO e dos materiais orgânicos que foram utilizados neste trabalho

Por fim, serão brevemente descritas as técnicas experimentais utilizadas durante o desenvolvimento deste trabalho.

\section{1 \\ Crescimento dos filmes de grafeno}

Os filmes de grafeno foram sintetizados na Divisão de Metrologia de Materiais (Dimat), do Instituto Nacional de Metrologia, Qualidade e Tecnologia (Inmetro) a partir da técnica de deposição química na fase de vapor (CVD). Para isso, utilizamos folhas de cobre policristalino de $25 \mu \mathrm{m}$ de espessura (Alfa Aesar - item $n^{\circ}$ 13382) para atuarem como substratos catalíticos na síntese do grafeno por CVD. A Figura 30 (a) esquematiza o sistema de CVD utilizado, destacando as linhas de fluxo de gases e os respectivos medidores, além do forno tubular e do tubo de quartzo (com 1,20 m de comprimento e 5 cm de diâmetro), no qual o substrato de cobre é inserido. A Figura 30 (b) mostra parte do sistema de CVD utilizado.

Para o crescimento dos filmes de grafeno realizamos diversos testes a fim de avaliar as melhores condições e parâmetros experimentais. Durante esta etapa, a concentração e o tempo de exposição dos gases usados foram investigados. 

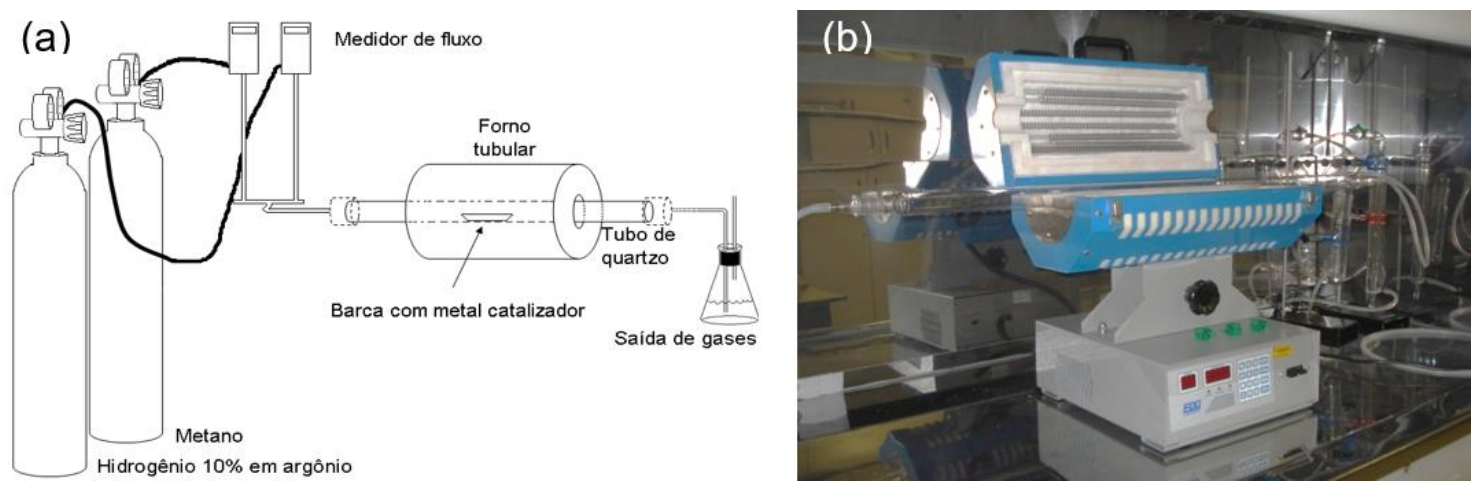

Figura 30: (a) Representação esquemática da instalação do sistema de deposição por CVD. (b) Sistema de deposição utilizado.

Os filmes de grafeno que apresentaram a melhor qualidade possível (filmes íntegros, com pouca quantidade de carbono amorfo, entre outros) foram crescidos da seguinte forma:

i) Aquece-se a folha de cobre até $1000{ }^{\circ} \mathrm{C}$ dentro do tubo de quartzo com um fluxo de mistura de $\mathrm{Ar} / \mathrm{H}_{2}$ (9:1) de $3000 \mathrm{sccm}$ (3 L/min);

ii) Após atingir a temperatura de $1000{ }^{\circ} \mathrm{C}$, um fluxo de metano $\left(\mathrm{CH}_{4}\right)$ é introduzido com $20 \mathrm{sccm}(0,02 \mathrm{~L} / \mathrm{min})$ durante 15 minutos, a fim de formar o filme de grafeno sobre a folha de $\mathrm{Cu}$;

iii) Finalmente, o tubo é resfriado somente na presença de fluxo de mistura de $\mathrm{Ar} / \mathrm{H}_{2}(9: 1)$ de $3000 \mathrm{sccm}(3 \mathrm{~L} / \mathrm{min})$;

\section{2}

\section{Síntese da blenda de EPDM-PAni}

A blenda de EPDM-PAni é um compósito polimérico constituído de uma matriz de borracha de etileno-propileno-dieno (EPDM), a qual fornece o caráter flexível, com uma porcentagem de polianilina (PAni), a qual apresenta propriedade de condução elétrica. [66]

O EPDM é uma borracha obtida através da copolimerização do etileno, do propileno e do dieno, conforme mostra a Figura 31, sendo vastamente empregado na fabricação de tubos e mangueiras, entre outras aplicações. 


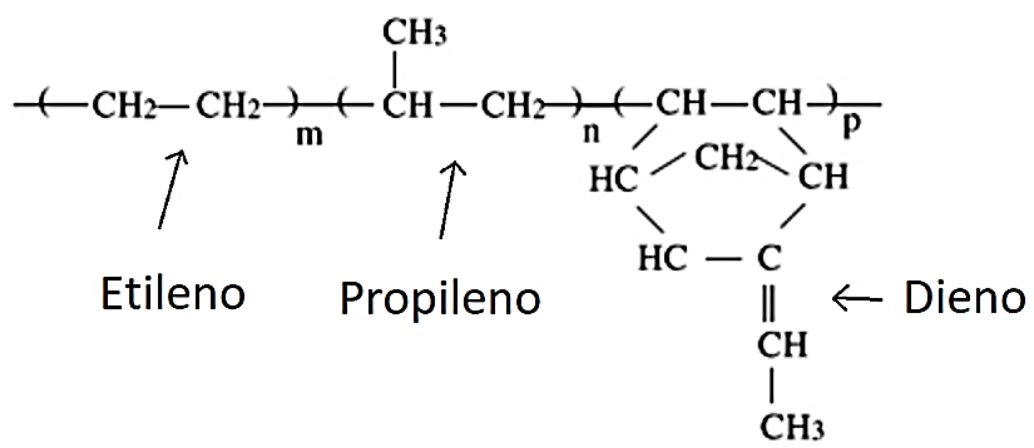

Figura 31: Estrutura polimérica do EPDM formado a partir dos monômeros de etileno, propileno e dieno. Adaptado de [67]

Os filmes de EPDM são oticamente transparentes e muito flexíveis, contudo possui alta resistividade elétrica [68], sendo necessário otimizá-los com um material polimérico flexível, condutor e quimicamente compatível, tal como a PAni.

Desde o início dos anos 80, a PAni tem recebido muita atenção devido a sua estabilidade química, facilidade de síntese e por apresentar alta condutividade elétrica, promovendo diversas aplicações que vão desde a fabricação de sensores químicos até a aplicações de revestimentos eletrocrômicos. [64]

A PAni pode ser sintetizada através de oxidação química da anilina em meio ácido, onde sua estrutura polimérica é representada por y e (1-y) unidades repetidas das espécies reduzida e oxidada, como mostra a Figura 32:

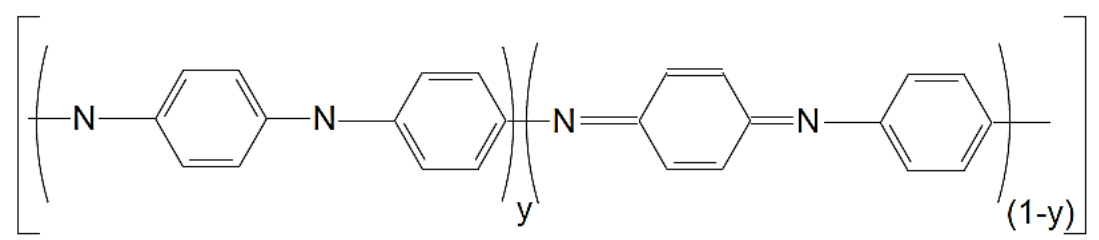

Figura 32: Estrutura polimérica da PAni. [69]

Para a síntese desta blenda de EPDM-PAni foi utilizado o copolímero comercial etileno propileno dieno (EPDM) doado pela LANXESS Ind. de Produtos Químicos e Plásticos Ltda.

Primeiramente, o EPDM é quimicamente modificado para se tornar compatível com a PAni, a qual é hidrofílica. Para esta finalidade, seguimos a seguinte rota: 
i) $\quad 20 \mathrm{~g}$ de EPDM foram dissolvidos em $180 \mathrm{ml}$ de clorobenzeno à $80^{\circ} \mathrm{C}$;

ii) A seguir, uma solução de $40 \mathrm{~mL}$ de clorobenzeno contendo $1 \mathrm{wt} \%$ de anidrido maleico e $0.5 \mathrm{wt} \%$ de peróxido de benzoíla (porcentagens em relação à massa do EPDM) foi preparada;

iii) Na sequência, as duas soluções foram misturadas sob agitação mecânica. Após 20 h a solução foi precipitada com acetona, no qual o EPDM foi decantado e o sobrenadante removido;

iv) Por fim, o EPDM foi mantido sob vácuo durante 24 horas, à temperatura de $50{ }^{\circ} \mathrm{C}$ para promover sua secagem;

Após esta prévia modificação, o processo de síntese da blenda EPDM-PAni, ilustrado na Figura 33, segue a seguinte rota:

i) $1 \mathrm{~g}$ do EPDM modificado foi pré-dissolvido com $70 \mathrm{~mL}$ de clorofórmio sob agitação magnética;

ii) Em seguida foi adicionado $2 \mathrm{~mL}$ de anilina, a qual foi previamente destilada sob vácuo a $130^{\circ} \mathrm{C}$ para eliminar impurezas;

iii) Posteriormente, foram adicionados, gota a gota, $5 \mathrm{~g}$ de persulfato de amônia dissolvido em $50 \mathrm{~mL}$ de ácido clorídrico, enquanto a mistura era mantida sob agitação mecânica à temperatura de aproximadamente $-5^{\circ} \mathrm{C}$;

iv) Como resultante deste processo, a mistura apresenta-se com cor verde escura. A mistura de EPDM-PAni foi mantida nesta condição durante $20 \mathrm{~h}$.

v) Por fim, para eliminar aglomerados de PAni e assim diminuir a rugosidade dos filmes após a deposição, a solução de EPDM-PAni foi filtrada com filtros de diferentes porosidades: filtro de $450 \mathrm{~nm}$ (Millex-HV, PVDF), de 220 nm (Millex-HV, PVDF) e de 100 nm (Sartorius, Minisart High-flow PES). 


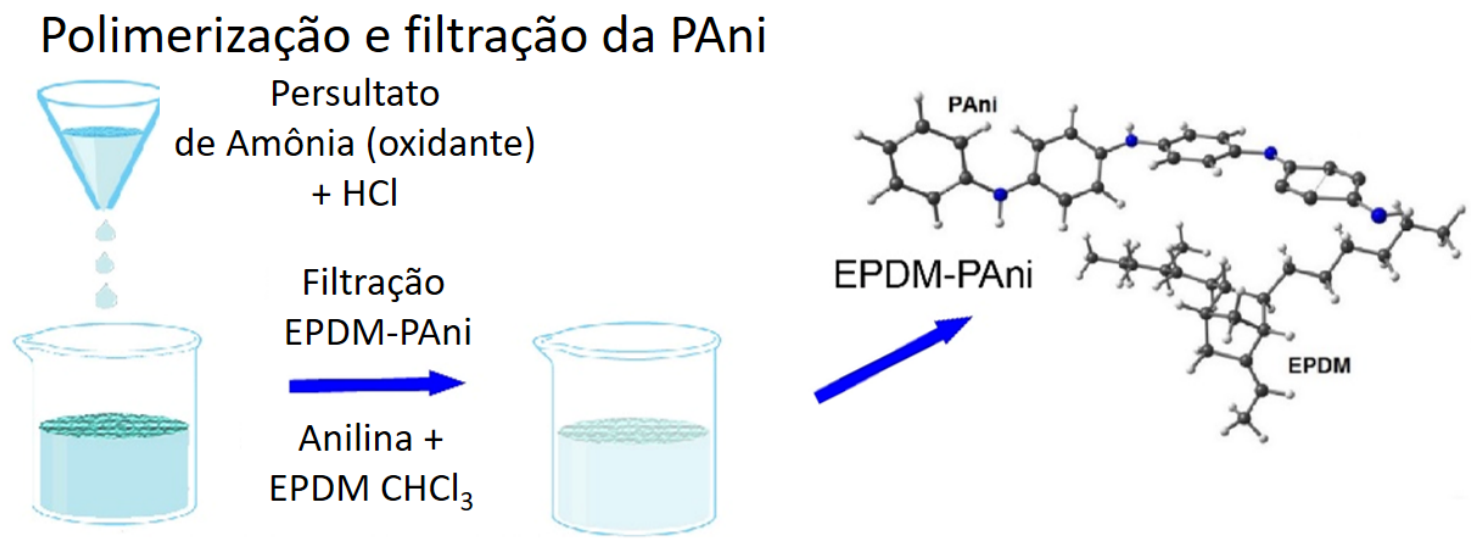

Figura 33: Ilustração do processo de síntese da blenda de EPDM-PAni.

Em conjunto com o procedimento descrito acima, realizamos um estudo com diferentes porcentagens em massa de PAni em EPDM. Para isso foram feitas sínteses variando de 5 a 50 wt\% de PAni. Medidas de resistência de folha, transmitância ótica e rugosidade foram realizadas nos filmes produzidos, para avaliar a melhor condição de concentração de PAni na blenda de EPDM-PAni.

No caso, observamos que a melhor condição de síntese ocorreu com a concentração de 30 wt\% de PAni em EPDM. Maiores detalhes serão descritos no Capítulo 4 Resultados e discussões.

\section{3}

\section{Transferência dos filmes de grafeno}

Conforme havíamos descrito anteriormente, o processo de transferência do grafeno da folha catalítica para o substrato desejado é um processo sistemático e que precisa ser feito com cuidado para não transferir involuntariamente sujeiras ou demais resíduos capazes de prejudicarem a performance do respectivo dispositivo.

Para a fabricação de dispositivos fotovoltaicos orgânicos faz-se necessário transferir o grafeno para um material oticamente transparente e que atue como suporte mecânico, como por exemplo o vidro.

Neste contexto, descrevo sobre dois processos de transferência dos filmes de grafeno: o processo tradicional, o qual utiliza o PMMA e um processo desenvolvido durante esta tese, no qual utiliza-se uma blenda de EPDM-PAni, a qual não é removida ao final da transferência e também maximiza as propriedades do filme de grafeno. 
O processo de transferência convencional através do PMMA será descrito a seguir e o procedimento com EPDM-PAni será descrito no Capítulo 4 - Resultados e discussões.

\subsection{1}

\section{Processo tradicional de transferência utilizando PMMA}

Finalizado o processo de síntese de grafeno usando a técnica de CVD, a amostra de grafeno sobre cobre ( $\mathrm{Cu} /$ grafeno) é imediatamente retirada do interior do tubo de quartzo e recoberta por um filme de PMMA, logo após o resfriamento do forno.

A concentração da solução de PMMA usada é de 0,03 mol/L diluído em acetona, a qual é depositada através de gotejamentos com uma pipeta sobre a superfície do grafeno. A camada de PMMA depositada tem espessura na ordem de $600 \mu \mathrm{m}$ e como resultado final temos um sanduíche tipo Cu/grafeno/PMMA. A Figura 34 ilustra as demais etapas realizadas durante o processo de transferência do grafeno para o substrato de vidro:

(a) Após a evaporação do solvente e secagem do filme de PMMA depositado, o qual ocorreu em temperatura ambiente, o conjunto $\mathrm{Cu} /$ grafeno/PMMA é flutuado em uma solução de cloreto de ferro $\left(\mathrm{FeCl}_{3}\right)$, na concentração de $1 \mathrm{~mol} / \mathrm{L}$, com o objetivo de promover a corrosão do substrato de cobre;

(b) O resultante da corrosão (grafeno/PMMA) é flutuado em água deionizada, a qual auxilia na limpeza e remoção dos resíduos originados da prévia corrosão;

(c) O resultante do processo de lavagem (grafeno/PMMA) é mecanicamente aderido ao substrato desejado, no caso da Figura 34, no caso o substrato de vidro;

(d) Após a adesão do grafeno/PMMA sobre o vidro, formando o sanduíche vidro/grafeno/PMMA, o mesmo é retirado do meio aquoso e seco à temperatura ambiente em torno de $1 \mathrm{~h}$. Por fim, após este período, a amostra vidro/grafeno/PMMA é submersa em acetona e repousada durante $24 \mathrm{~h}$, a fim de promover a remoção por completo da 
camada de PMMA. Decorrido as 24h, resultando apenas o vidro/grafeno, este é retirado da acetona, lavado-o com álcool isopropílico e seco com nitrogênio gasoso $\left(\mathrm{N}_{2}\right)$.

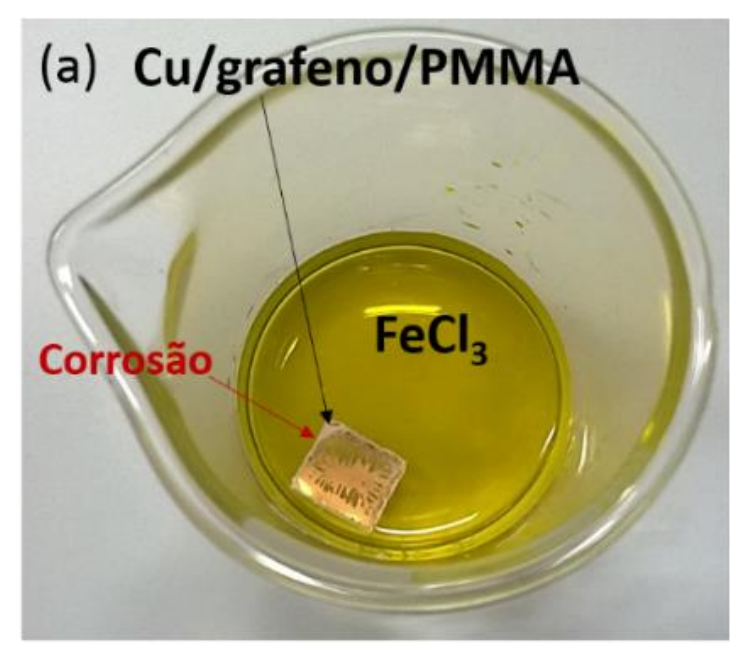

\section{(c) Grafeno/PMMA}

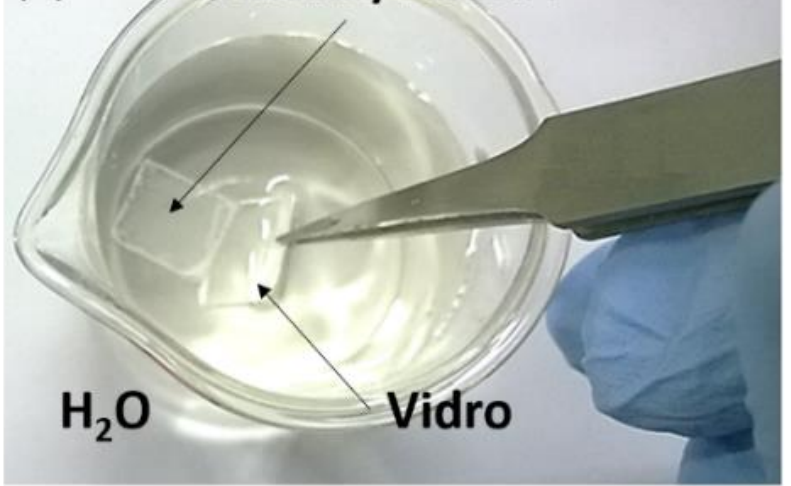

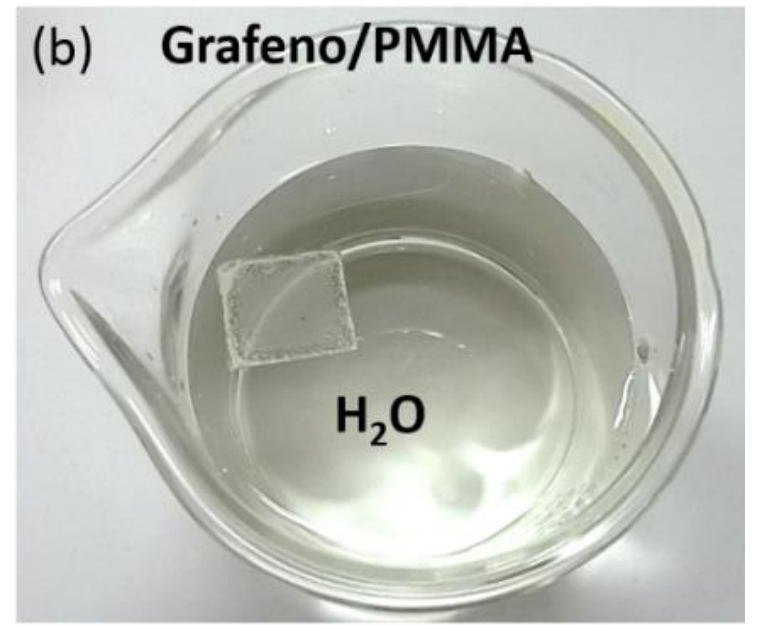

(d)

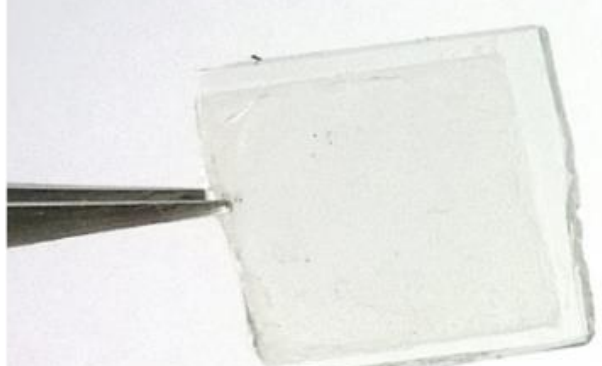

\section{Vidro/grafeno/PMMA}

Figura 34: Imagens do processo de transferência dos filmes de grafeno: (a) cobre com o filme de grafeno/PMMA flutuando na solução de $\mathrm{FeCl}_{3}$; (b) Grafeno/PMMA em água deionizada após a corrosão total do cobre; (c) Substrato de vidro apanhando o filme de grafeno/PMMA; (d) Imagem do grafeno/PMMA sobre o substrato de vidro.

Este método apesar de ser o mais utilizado, não elimina facilmente todos os resíduos originados do processo. Dessa forma, o processo de remoção do PMMA não é completo, deixando resíduos que tornam o eletrodo mais eletricamente resistivo e rugoso $[13,14]$. No Capítulo 4, que trata dos resultados obtidos nesta tese, será apresentado um novo método de transferência utilizando uma blenda de EPDM-PAni, a qual não é prejudicial ao filme de grafeno. 


\section{4 Materiais poliméricos utilizados na fabricação dos substratos flexíveis}

Diversos substratos poliméricos flexíveis têm sido citados na literatura em promissoras aplicações na área da Eletrônica Orgânica. Entre diversos, destaca-se o PET, Figura 35 (a), o qual possui baixo custo de produção, fácil processabilidade, além de ser flexível e oticamente transparente, atingindo valores de transmitância em torno de $90 \%$ dentro do espectro eletromagnético visível, conforme mostra a Figura 35 (b). [15, 18, 70, 71] Observa-se na Figura 35 que tanto o PET, quanto o vidro possuem transmitância ótica semelhantes. O vidro possui a vantagem de ser aproximadamente 5\% mais transparente em 550 nm do que o PET, porém este é flexível.

(a)

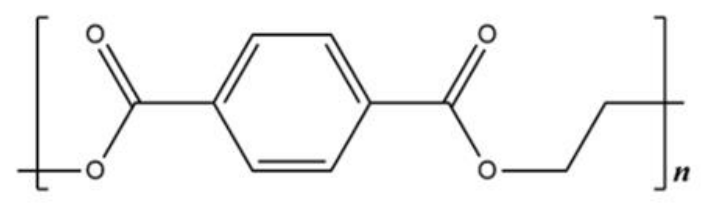

(b)

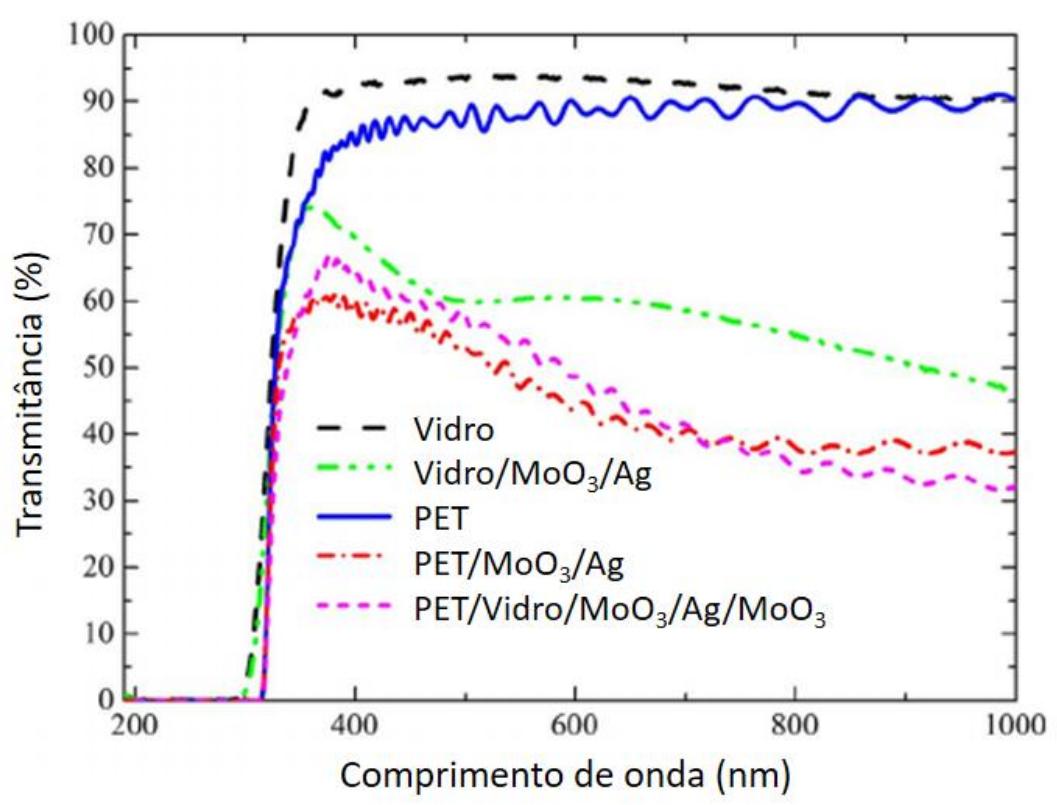

Figura 35: (a) Estrutura química do polietileno tereftalato (PET); (b) Espectro de transmitância ótica obtida em vidro (glass), PET e com ânodo de $\mathrm{MoO}_{3} / \mathrm{Ag}$. Adaptado de [70].

Outro substrato flexível que tem recebido destaque na Eletrônica Orgânica é a celulose bacteriana (BC), a qual apresenta grande interesse por ter fácil processo de síntese, por ser flexível e por possibilitar a integração com sistemas biológicos já que é biocompatível. Contudo, este tipo de substrato apresenta transmitância ótica muito abaixo do vidro e do PET, em torno de $50 \%$ em 550 nm, conforme mostra a Figura 36. [72, 73] 


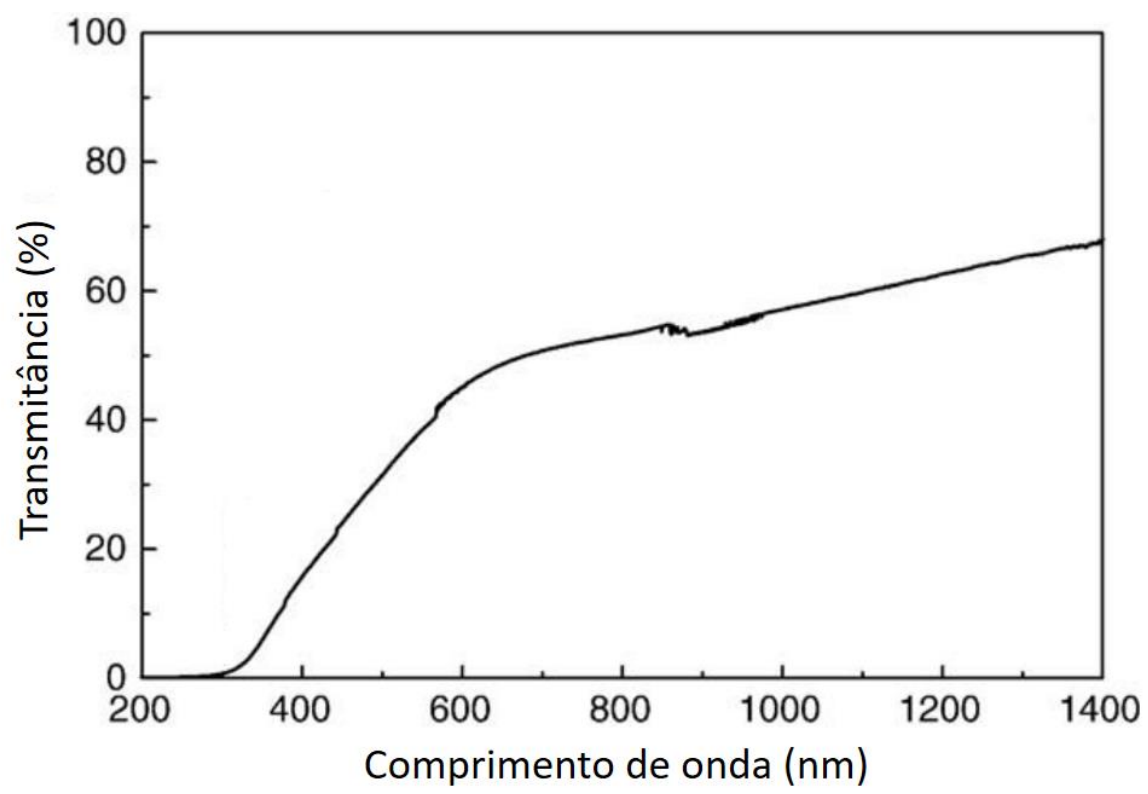

Figura 36: Espectro de transmitância ótica obtida a partir de um substrato de BC recoberto com $185 \mathrm{~nm}$ de ITO. Adaptado de [73].

Diversos trabalhos acerca dos substratos flexíveis têm sido desenvolvidos pelos grupos do Laboratório de Optoeletrônica Molecular (LOEM/PUC-Rio) e do Laboratório de Dispositivos Orgânicos (Lador/Inmetro), os quais já demonstram a experiência em desenvolver dispositivos orgânicos com esta tecnologia, onde a flexibilidade passou a ser um ponto chave para as pesquisas institucionais. [13, 63, 72-75]

Neste sentido, a fim de otimizar e desenvolver novos dispositivos flexíveis, os substratos poliméricos utilizados neste trabalho foram os seguintes: PVA, PVC e BC. Visto que estes substratos poliméricos são isolantes elétricos, estes precisam ser funcionalizados para aplicação em dispositivos fotovoltaicos orgânicos. Neste caso um substrato funcionalizado consiste em um substrato transparente (rígido ou flexível) recoberto com um eletrodo condutor transparente. Portanto, foi depositado óxido de índio e estanho (ITO) em uma de suas superfícies, resultando em um substrato híbrido (material polimérico e inorgânico) oticamente transparente e eletricamente condutor. As deposições de ITO foram realizadas utilizando parâmetros de fabricação prédeterminados, através da otimização do vidro/ITO, conforme será descrito posteriormente.

A seguir será feito uma breve descrição sobre os materiais poliméricos utilizados nesta tese, os quais são o PVA, PVC e BC. Neste caso a BC é quimicamente modificada com PVC, como será descrito ao longo deste capítulo. 


\section{$\underline{\text { Poliacetato de Vinila (PVA) }}$}

O PVA é um polímero termoplástico sintético, produzido via hidrólise parcial ou total do acetato de polivinila, com objetivo de remover os grupos de funcionais de acetato. [76] A Figura 37 ilustra a estrutura química do monômero acetato de vinila, seguido do polímero poliacetato de vinila, sintetizado a partir de seu respectivo monômero.

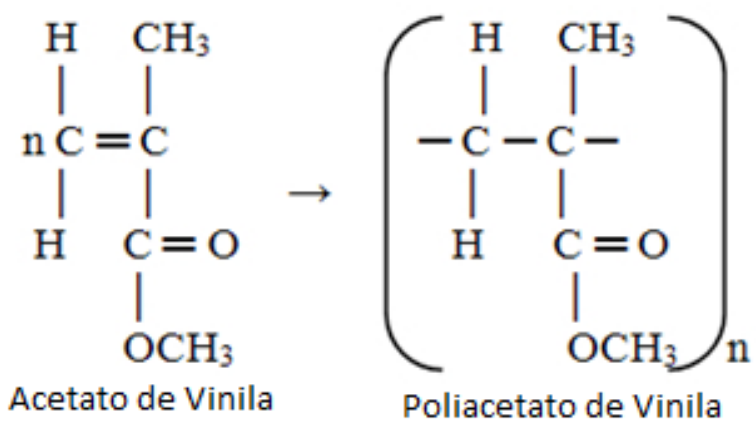

Figura 37: Estrutura química do monômero e do seu respectivo polímero, o poliacetato de vinila.

O PVA tem sido muito explorado comercialmente devido ao seu baixo impacto ambiental, alta resistência química, principalmente contra solventes orgânicos, a alta solubilidade aquosa e biodegradabilidade. Estas características permitem diversas aplicações industriais, as quais vão desde embalagens para produtos alimentícios até em aplicações ortopédicas e biomecânicas.

Este material também tem sido utilizado na fabricação de membranas para ferimentos, tal como peles artificiais ou curativos, mostrando a potencialidade deste material em dispositivos eletrônicos orgânicos biocompatíveis. [77]

\section{$\underline{\text { Policloreto de Vinila (PVC) }}$}

Assim como o PVA, o PVC também é um polímero classificado como termoplástico. O PVC é sintetizado a partir da reação de radicais livres de cloreto de vinila e possui estrutura química predominantemente linear, como mostra a Figura 38, contudo podendo polimerizar pequenas ramificações laterais. 


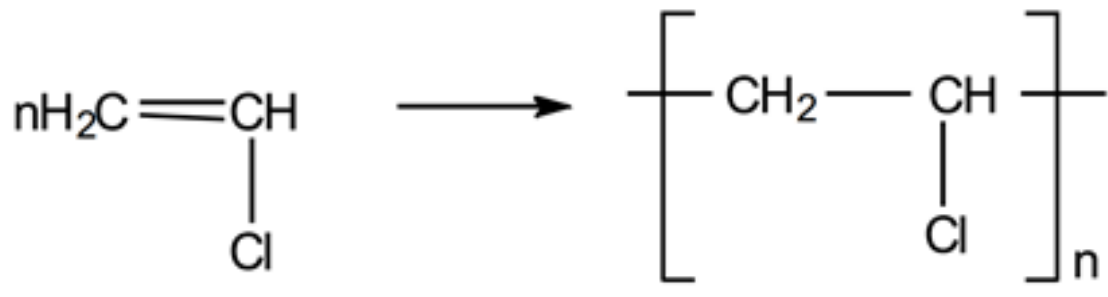

Cloreto de Vinila

Policloreto de Vinila

Figura 38: Estrutura química do monômero e do seu respectivo polímero, o policloreto de vinila.

As propriedades de flexibilidade, impermeabilidade à gases e líquidos, a alta resistência química, em conjunto com a alta transparência ótica são vantagens que direcionam a utilização deste material como substratos flexíveis em dispositivos eletrônicos orgânicos. Além disso, pelo fato do PVC ser atóxico, este material também permite a integração da eletrônica orgânica com sistemas biológicos.

\section{Celulose Bacteriana (BC) modificada com PVC}

A celulose bacteriana é um material polimérico com uma vasta aplicabilidade por ser biodegradável e biocompatível, não tóxico e não alergênico, sendo inclusive utilizado para fins alimentícios. [78]

A fonte de celulose mais utilizada atualmente é a madeira de eucalipto. Porém, existem outras formas conhecidas de obtenção da celulose, tais como através de outras plantas, síntese enzimática e química ou até por alguns microrganismos. Entre os microrganismos destaca-se o Acetobacter xylinum, o qual é a única espécie conhecida capaz de produzir celulose em quantidades comerciais. [63]

A Figura 39 apresenta a estrutura química da BC. As ligações de hidrogênio presentes na estrutura são responsáveis por sua insolubilidade à água e em diversos solventes químicos. [63]

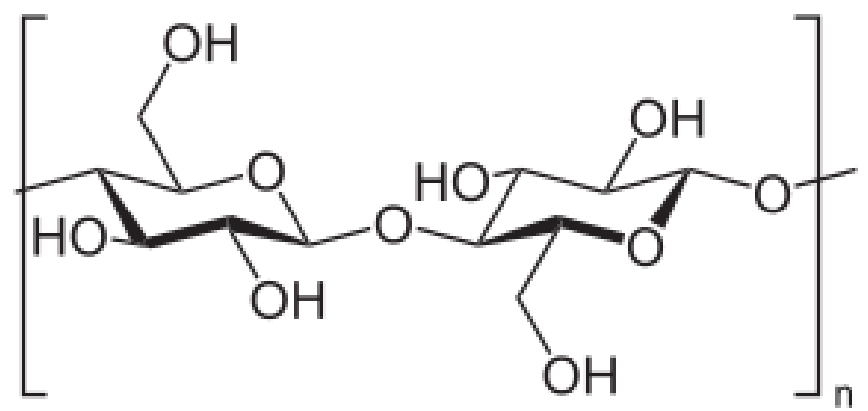

Figura 39: Estrutura química da BC, tanto para celulose natural, quanto sintetizada. 
As aplicações da celulose bacteriana são amplas, tais como sobremesa dietética conhecida como "nata de coco", diafragmas acústicos de alto falantes e fones de ouvidos, substituição de pele lesionada, entre outras. [63] Entre as várias aplicações destaco a utilização como substrato flexível em dispositivos orgânicos. Uma nova aplicação sugerida em nosso grupo é a utilização da celulose bacteriana como substrato flexível em OLEDs, com a finalidade de tratar doenças de pele, como o câncer, através da terapia fotodinâmica. [73, 79-81] Os primeiros OLEDs, com essa finalidade, foram construídos em substratos de vidro e afixadas à pele por meio de fitas metálicas que agem também como dissipadores de calor, como mostrado na Figura 40. [80] Desta forma, o vidro fica em contato direto com a pele o que pode não permitir as trocas gasosas necessárias para a saúde. Assim, uma forma apropriada e inovadora de se contornar tal problema pode ser a utilização de membranas de celulose bacteriana como substratos flexíveis para estes OLEDs.

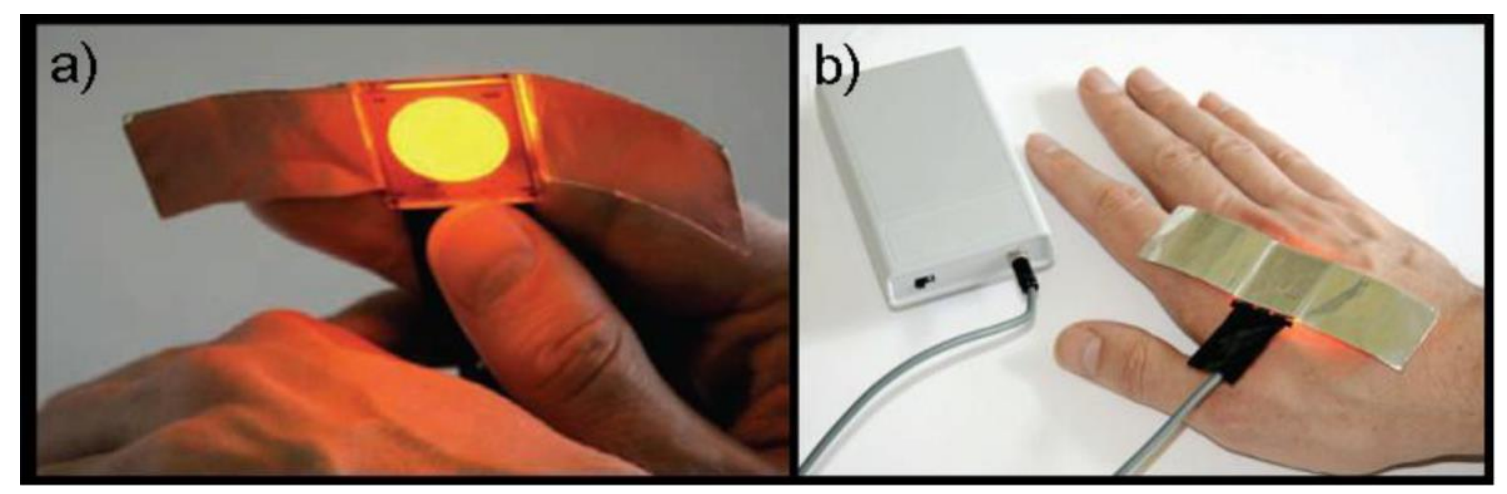

Figura 40: (a) Imagem do OLED utilizado para fototerapia dinâmica. b) Aparelho portátil completo para realização do tratamento. [80]

Apesar da BC apresentar todas as propriedades necessárias para ser utilizada como um substrato flexível e transparente, ela apresenta uma opacidade prejudicando a sua transparência. [63] Para contornar este problema, neste trabalho o PVC foi utilizado como agente modificador da BC, no qual a transmitância ótica da BC aumenta significantemente, conforme será relatado no Capítulo 4 - Resultados e discussões.

\section{5}

\section{Sistema de deposição de materiais orgânicos, metálicos e óxidos}

Conforme mencionado anteriormente, este doutoramento foi desenvolvido em cooperação entre duas instituições: o Laboratório de Dispositivos Orgânicos (Lador) da 
Divisão de Metrologia de Materiais (Dimat) do Inmetro e o Laboratório de Opto Eletrônica Molecular (LOEM) do Departamento de Física da PUC-Rio.

A deposição dos filmes de ITO, a fabricação dos dispositivos à base de grafeno e parte dos dispositivos fabricados com substratos flexíveis foram realizados no sistema de deposição do Lador/Inmetro. Um segundo grupo de dispositivos, também com substratos flexíveis, foi fabricado no sistema de deposição do LOEM/PUC-Rio. Na sequência será descrito o sistema de deposição de cada instituição.

\subsection{1}

\section{Infraestrutura para a fabricação dos dispositivos fotovoltaicos orgânicos}

O sistema de deposição do Lador/Inmetro é mostrado na Figura 41. Esse sistema é composto por três câmeras de alto vácuo fabricado pela Angstron Engeneering.

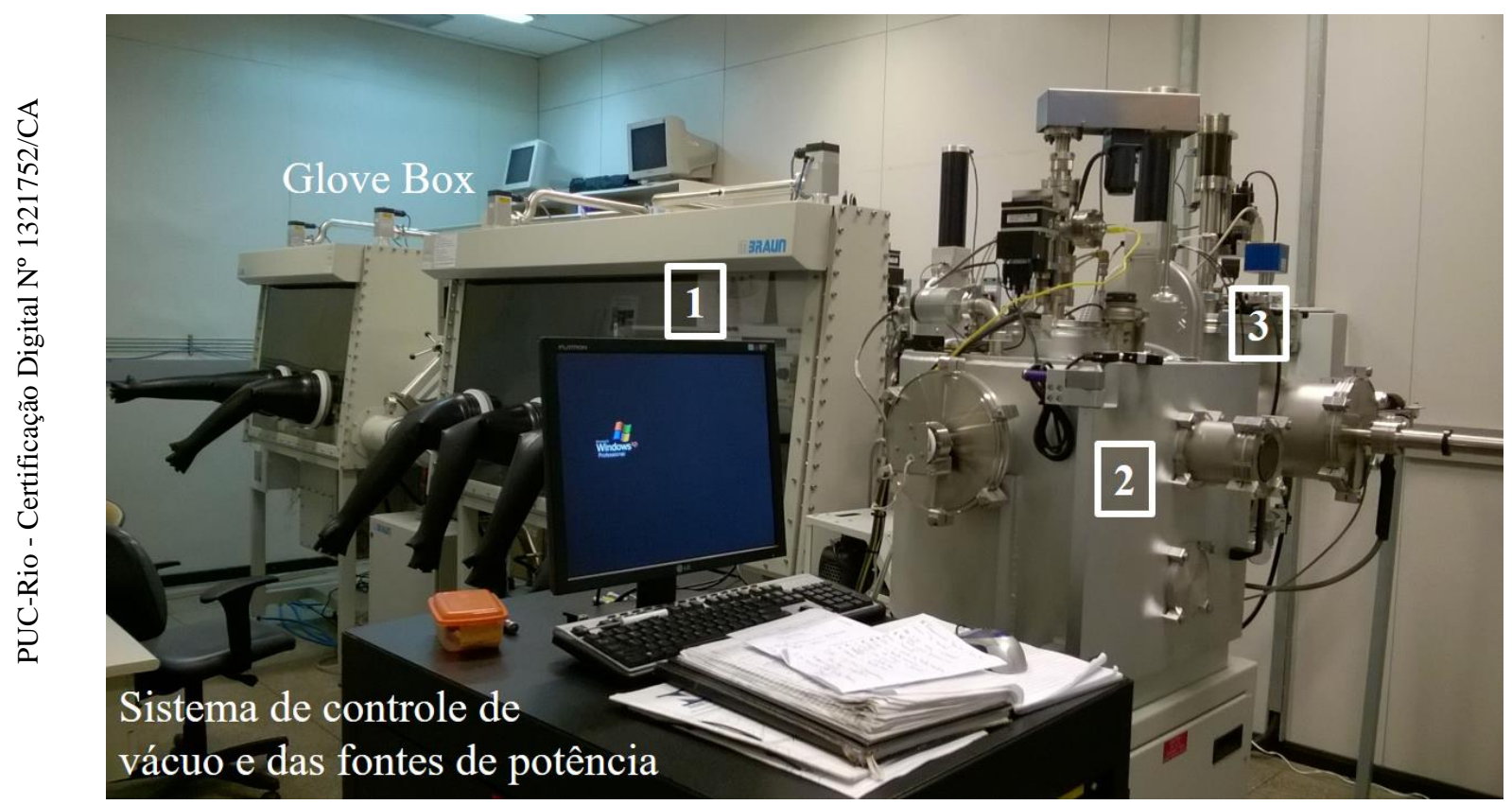

Figura 41: Sistema de deposição de filmes finos do Laboratório de Dispositivos Orgânicos (Lador) da Dimat/Inmetro.

Conforme indicado na Figura 41, a câmara 1 é utilizada para a deposição dos materiais orgânicos pelo método de evaporação térmica resistiva. Esta câmara fica localizada no interior de uma glove box, marca MBraun com atmosfera inerte de nitrogênio gasoso. A câmara 2 é utilizada para deposição de metais por evaporação térmica resistiva e de ITO e outros materiais pelo método de pulverização catódica assistida por radiofrequência. As câmeras 1 e 2 estão conectas por meio da câmera 3, a 
qual permite a transferência das amostras de uma câmera para a outra em vácuo, sem necessidade de expor o dispositivo em fabricação ao ambiente externo.

O sistema de deposição do LOEM/PUC-Rio é mostrado na Figura 42. Esse sistema é composto por uma câmara de alto vácuo modelo Univex 300 da marca Leybold, inserida em uma glove box da marca MBraum com atmosfera inerte de nitrogênio gasoso. Esta câmara é utilizada para deposições tanto de materiais orgânicos, quanto metálicos, pelo método de evaporação térmica resistiva.

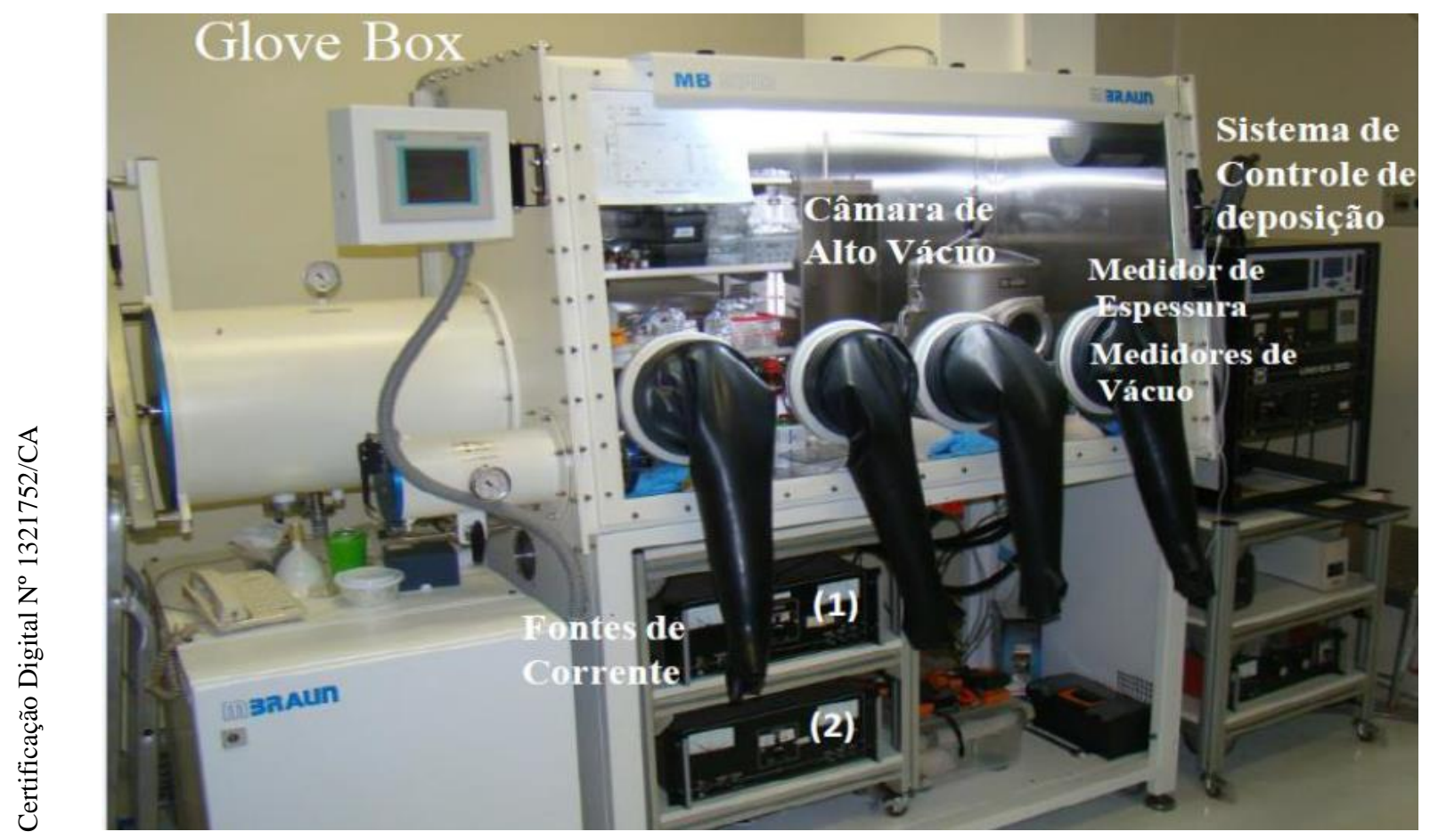

Figura 42: Sistema de deposição de filmes finos do Laboratório de Opto Eletrônica Molecular (LOEM) da PUC-Rio.

Importante destacar que ambos os sistemas são compostos por um conjunto de vácuo, contendo com bomba mecânica e turbo molecular, medidores de pressão, fontes de corrente e um controlador de espessura de filme fino, baseado em um sensor de quartzo, marca XTC-Inficom, capaz de monitorar a taxa de deposição dos filmes a partir da potência transferida da fonte de corrente para o metal e da densidade do mesmo.

A seguir serão descritos detalhes sobre os processos de deposição de materiais óxidos, orgânicos e metálicos, utilizados na fabricação dos dispositivos fotovoltaicos orgânicos. 


\subsection{2 Deposição dos filmes de ITO}

Conforme mencionado anteriormente, os filmes de ITO foram depositados sobre os substratos poliméricos de PVA, PVC e BC resultando em substratos híbridos para a aplicação em dispositivos fotovoltaicos orgânicos flexíveis.

Os filmes de ITO foram depositados por pulverização catódica com radiofrequência assistida por campo magnético constante, no sistema do Lador/Inmetro. Esta é uma das técnicas de deposição física por fase vapor (PVD, do inglês physical vapor deposition), relacionada à condensação de compostos na fase gasosa formando filmes no estado sólido sobre um substrato. Neste processo, o material a ser depositado é um alvo sólido que é removido progressivamente pelo bombardeamento de íons energéticos que constituem um plasma gasoso, eletricamente carregado e a baixa pressão.

Para a deposição de ITO foi utilizado um alvo cerâmico de 3 polegadas de diâmetro, contendo $\mathrm{In}_{2} \mathrm{O}_{3}$ e $\mathrm{SnO}_{2}$ na proporção de 9:1 em peso, fabricado pela Kurt J. Lesker Company. A distância entre o alvo e a amostra é de aproximadamente $12 \mathrm{~cm}$, com inclinação em torno de $30^{\circ}$ em relação à vertical.

A pressão base em todas as deposições era sempre abaixo de $9 \times 10^{-7}$ Torr. Antes de começar a deposição dos filmes de ITO é realizado três purgas com gás de argônio, afim de eliminar quaisquer resquícios de gases residuais no interior da câmara de deposição. Deste modo, a câmara é preenchida com argônio (99,999\% de pureza da White Martins) com um fluxo de aproximadamente $18,5 \mathrm{sccm}$, atingindo a pressão de $2 \times 10^{-3}$ Torr durante 2 minutos. Ao final deste tempo, o fluxo de argônio é fechado e espera-se atingir a pressão de base típica de $9 \times 10^{-7}$ Torr. Este processo de purga é repetido 3 vezes para garantir a limpeza total do sistema, a qual é controlado através por níveis de $\mathrm{O}_{2}$ e $\mathrm{H}_{2} \mathrm{O}$. A deposição de ITO apenas é realizada após este processo de purgas do sistema e da otimização dos parâmetros, conforme será descrito a seguir.

Nesta etapa do trabalho foi realizado um estudo a fim de determinar a melhor condição para a deposição de ITO sobre vidro, a partir da variação de diferentes parâmetros de fabricação. O controle de qualidade do vidro/ITO fabricado foi feito mediante a menor resistência de folha apresentada e a transmitância ótica no visível, os quais são apresentados no próximo capítulo. 


\subsection{3 \\ Deposição dos materiais orgânicos e metálicos}

Os dispositivos orgânicos, entre estes os fotovoltaicos, são construídos através de uma série de deposição de diversos filmes finos, tanto orgânicos, quanto inorgânicos. Para isto, existem diferentes métodos de deposição, tais como: evaporação térmica resistiva, eletroquímica, spin coating, dip coating, impressão, etc. A seguir descrevo de forma breve o método de evaporação térmica resistiva, que é um dos métodos mais utilizados para a deposição de filmes finos e foi o método utilizado neste trabalho.

Neste método de deposição, um cadinho contendo o material a ser depositado e o substrato são colocados no interior de uma câmera de alto vácuo. Uma quantidade de corrente elétrica é fornecida ao cadinho, que por efeito Joule é aquecido, resultando na evaporação do material contido no interior do cadinho, que se deposita formando um filme no substrato. As espessuras dos filmes são monitoradas durante os processos de evaporação, usando uma micro balança de quartzo, que é previamente calibrada.

Neste trabalho, após já termos fabricados os substratos funcionalizados (substrato/eletrodo) como explicado nas seções anteriores, os filmes orgânicos foram depositados sequencialmente pela técnica de evaporação térmica resistiva com uma pressão da ordem de $10^{-6}$ Torr. $\mathrm{O}_{60}$ foi depositado na taxa de $0,2 \AA / \mathrm{A}$ e os demais materiais orgânicos na taxa de $0,5 \AA$ s. Os materiais orgânicos e suas funções na estrutura do dispositivo são discutidas na próxima seção.

No Capítulo 2 foi mencionado que o $\mathrm{C}_{60}$ possui baixa solubilidade em solventes orgânicos e, portanto, é depositado apenas pela técnica de evaporação térmica resistiva em dispositivos fotovoltaicos orgânicos com estruturas em heterojunção em bicamada. Porém, em estruturas com heterojunção em volume este material não é utilizado sendo substituído por outros, tal como o PCBM que pode ser depositado em solução através da mistura com um material doador de elétrons. Neste trabalho foi feita a deposição do $\mathrm{C}_{60}$ tanto na estrutura com heterojunção em bicamada, quanto em volume utilizando a técnica de evaporação térmica resistiva. Na estrutura com heterojunção em volume fizemos uma codeposição do $\mathrm{C}_{60}$ e do material doador de elétrons, no qual os dois materiais orgânicos são depositados simultaneamente.

A deposição do eletrodo metálico é realizada após a deposição das camadas orgânicas. Quando os dispositivos são fabricados no sistema de deposição do Lador/Inmetro, os filmes orgânicos são depositados na câmara 1 (como visto na Figura 
41), sendo transferidos, ainda em vácuo, através da câmara 3, para a câmara 2 . Os eletrodos de $\mathrm{Ca}$ e $\mathrm{Al}$ foram depositados na câmara 2 com pressão da ordem de $10^{-6}$ Torr na taxa de $0,3 \AA /$ s e $1 \AA /$ s, respectivamente.

No sistema de deposição do LOEM/PUC-Rio (Figura 42) os materiais orgânicos e metálicos são depositados na mesma câmara com pressão da ordem de $10^{-6}$ Torr e, portanto, o filme metálico foi depositado na sequência dos filmes orgânicos. Nas estruturas dos dispositivos fabricados no LOEM/PUC-Rio foram utilizados apenas eletrodos de $\mathrm{Al}$ depositados na taxa de $1 \AA /$ s.

As estruturas e espessuras dos materiais orgânicos e metálicos utilizadas nos dispositivos fotovoltaicos orgânicos são apresentadas na seção 3.6 deste capítulo.

\subsection{4}

Materiais orgânicos utilizados na fabricação dos dispositivos

Nesta tese, os materiais utilizados na fabricação dos dispositivos fotovoltaicos orgânicos foram escolhidos de forma a maximizar a eficiência de conversão de potência dos dispositivos fotovoltaicos orgânicos fabricados, a partir dos seus respectivos portadores de carga e níveis energéticos.

Visto que os materiais alvos desta pesquisa se referem ao uso do grafeno e dos substratos poliméricos funcionalizados, atuantes como substratos condutores e transparentes, utilizamos alguns materiais bem conhecidos na literatura, os quais atuam como nossa referência para a fabricação dos dispositivos. São eles:

$\underline{\text { Ftalocianina de cobre }(\mathrm{CuPc}) \text { e de estanho }(\mathrm{SnPc})}$

A estrutura molecular do CuPc, mostrada na Figura 43, é descrita pela fórmula química $\mathrm{C}_{32} \mathrm{H}_{16} \mathrm{CuN}_{8}$.

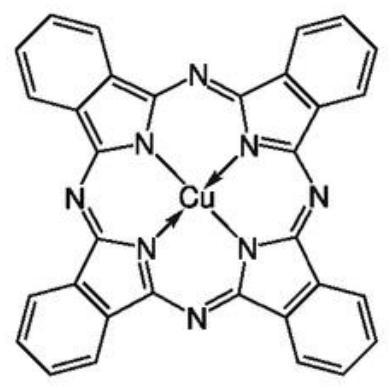

Figura 43: Estrutura quimica do CuPc. 
Este material é um pigmento corante bem conhecido na literatura por apresentar características de um semicondutor orgânico, com níveis energéticos em torno de 5.3 e $3.6 \mathrm{eV}$ para o HOMO e LUMO, respectivamente, sendo comumente utilizado como camada injetora de buracos. Entretanto, este material não possui boas propriedades de condução elétrica, fazendo com que a espessura de sua camada tenha que ser reduzida e bem controlada. [82, 83]

O CuPc é comumente utilizado em heterojunções nos dispositivos fotovoltaicos orgânicos em conjunto com o fulereno $\left(\mathrm{C}_{60}\right)$ ou o PCBM (phenyl-C61-butyric acid methyl ester), resultando em dispositivos com baixa eficiência. [2, 44]

O SnPc e o CuPc possuem origem na mesma classe das ftalocianinas e diferenciamse quimicamente pela substituição do átomo de cobre $(\mathrm{Cu})$ pelo de estanho $(\mathrm{Sn})$, no centro da estrutura molecular. Os níveis energéticos de HOMO e LUMO para o SnPc são 5.2 e $4.0 \mathrm{eV}$, respectivamente, sendo também utilizado como camada injetora de buracos. F. Yang e colaboradores [83] mostraram que o uso combinado do SnPc e do $\mathrm{CuPc}$ em conjunto com o $\mathrm{C}_{60}$ resulta em um dispositivo fotovoltaico orgânico com maior densidade de corrente de curto-circuito $\left(\mathrm{J}_{\mathrm{SC}}\right)$, conforme pode ser observado na Figura 44.
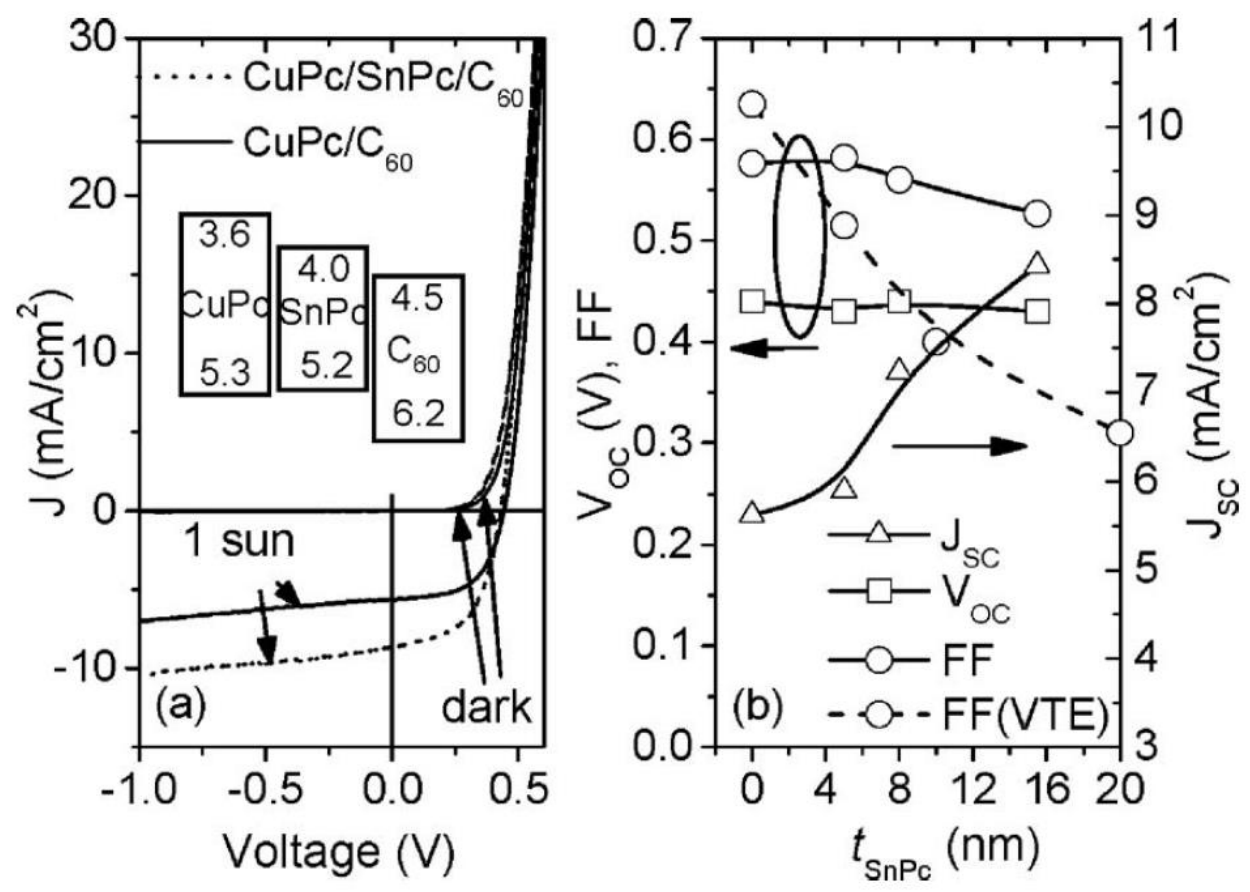

Figura 44: (a) Curvas características tipo $\mathrm{J} \times \mathrm{V}$ obtidas de um dispositivo bicamada formado por $\mathrm{CuPc}(15$ $\mathrm{nm}) / \mathrm{C}_{60}(40 \mathrm{~nm})$ e de um tricamada formado por $\mathrm{CuPc}(15 \mathrm{~nm}) / \mathrm{SnPc}(16 \mathrm{~nm}) / \mathrm{C60}(40 \mathrm{~nm})$, nas condições de escuro (dark) e sob $100 \mathrm{~mW} / \mathrm{cm}^{2}$ (1 sun); (b) Dependência da tensão de circuito aberto (Voc), do fator de preenchimento $(\mathrm{FF})$ e da densidade de corrente de curto-circuito $\left(\mathrm{J}_{\mathrm{sc}}\right)$ em relação à espessura do filme de SnPc na estrutura ITO/CuPc $(15 \mathrm{~nm}) / \mathrm{SnPc}\left(\mathrm{t}_{\mathrm{SnPc}}\right) / \mathrm{C}_{60}(40 \mathrm{~nm}) / \mathrm{BCP} / \mathrm{Ag}$. [83] 
Observa-se na Figura 44, que o incremento da espessura de $\mathrm{SnPc}\left(\mathrm{t}_{\mathrm{SnPc}}\right)$ resulta em um aumento da densidade de corrente de curto-circuito $\left(\mathrm{J}_{\mathrm{SC}}\right)$ e uma redução do fator de preenchimento (FF), no qual o maior valor da eficiência de conversão de potência (PCE) ocorreu na condição de $16 \mathrm{~nm}$ de SnPc. [83]

\section{Fulereno $\left(\mathrm{C}_{60}\right)$}

A molécula de $\mathrm{C}_{60}$ é formada basicamente por átomos de carbono em uma estrutura tridimensional, como mostrada na Figura 45. Sua estrutura no formato de um icosaedro é constituída de estruturas cíclicas pentagonais e hexagonais interligadas, com diâmetro na ordem de $1 \mathrm{~nm}$.

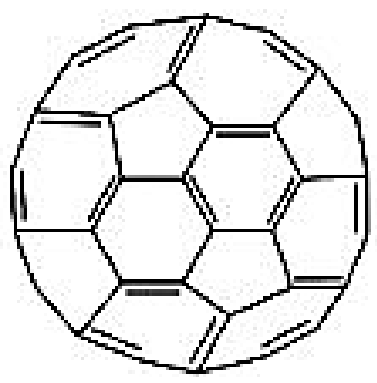

Figura 45: Estrutura química do fulereno $\mathrm{C}_{60}$.

Os carbonos adjacentes ligam-se por hibridização tipo $\mathrm{sp}^{2}$, como no grafeno, entretanto a curvatura trigonal das ligações leva a formação de uma estrutura pseudo sp ${ }^{3}$. [84]

Diversos derivados de fulerenos podem ser preparados a partir da inclusão de grupos funcionais, dando origem a novas estruturas, chamados de fulerenos funcionalizados. $\mathrm{O}_{60}$ e seus derivados são os materiais mais usados como materiais aceitadores de elétrons. Este é o caso do PCBM, mostrado previamente na Figura 2. Assim como o $\mathrm{C}_{60}$, o PCBM tem sido extensamente aplicados na fabricação de dispositivo fotovoltaico orgânico, principalmente em conjunto com o $\mathrm{CuPc}$ e o $\mathrm{SnPc}$, conforme comentado anteriormente. 
$\underline{\text { Tris (8-hydroxyquinolinato) de alumínio }\left(\mathrm{Alq}_{3}\right)}$

$\mathrm{O} \mathrm{Alq}_{3}$ é um material amplamente utilizado como camada emissora e como camada transportadora de elétrons. A estrutura molecular do $\mathrm{Alq}_{3}$ é mostrada na Figura 46, sendo descrita pela fórmula química $\mathrm{C}_{27} \mathrm{H}_{18} \mathrm{AlN}_{3} \mathrm{O}_{3}$. [85].

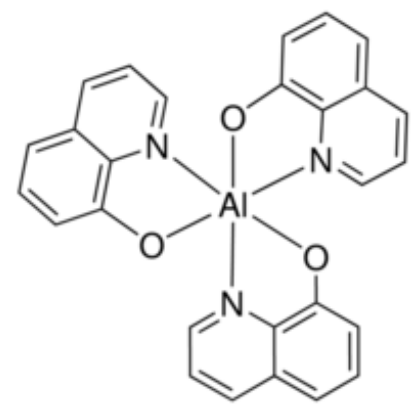

Figura 46: Estrutura química do $\mathrm{Alq}_{3}$ formado por três ligantes de hidroxiquinolina.

Este material possui niveis energéticos de HOMO e LUMO de 5.8 e $3.0 \mathrm{eV}$, sendo utilizado no primeiro diodo emissor de luz orgânico (OLED) de baixo peso molecular relatado por Tang [3] em 1987, devido a sua alta estabilidade térmica, alto rendimento quântico de fluorescência e alta capacidade de transporte de elétrons, além de fácil sintetização e pode ser evaporado à vácuo.

\section{$\underline{\text { 2,2',2"-(1,3,5-Benzinetriyl)-tris(1-phenyl-1-H-benzimidazole) (TPBI) }}$}

O TPBI é comumente utilizado como material transportador de elétrons em dispositivos eletrônicos orgânicos. Além disso, este material também é utilizado em diodos emissores de luz fluorescente e fosforescente, pelo fato de seu nível energético LUMO ser de $2.7 \mathrm{eV}$, enquanto o HOMO $6.3 \mathrm{eV}$. [86, 87]

A estrutura molecular do TPBI é mostrada na Figura 47, sendo descrita pela fórmula química $\mathrm{C}_{45} \mathrm{H}_{30} \mathrm{~N}_{6}$. 


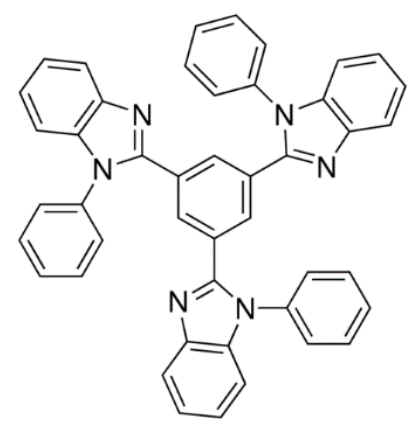

Figura 47: Estrutura química do TPBI.

\section{6 Estruturas dos dispositivos fotovoltaicos orgânicos fabricados}

$\underline{\text { Dispositivos fabricados com eletrodos à base de grafeno }}$

Os dispositivos com eletrodos à base de grafeno foram fabricados e caracterizados de modo a investigar a potencialidade de uso dos filmes de grafeno e de grafeno/EPDMPAni como eletrodos transparentes e condutores em dispositivos fotovoltaicos orgânicos, de acordo com a estrutura de heterojunção em bicamada, conforme mostrado na Figura 48.

Ainda nesta estrutura, investigamos o desempenho dos eletrodos de grafeno transferido com PMMA e de grafeno/EPDM-PAni, comparando com um análogo de ITO (15 $\Omega \mathrm{sq}^{-1}$, da Lumtec Corp.) sob as mesmas condições. O ITO atua como elemento de referência para os nossos dispositivos.
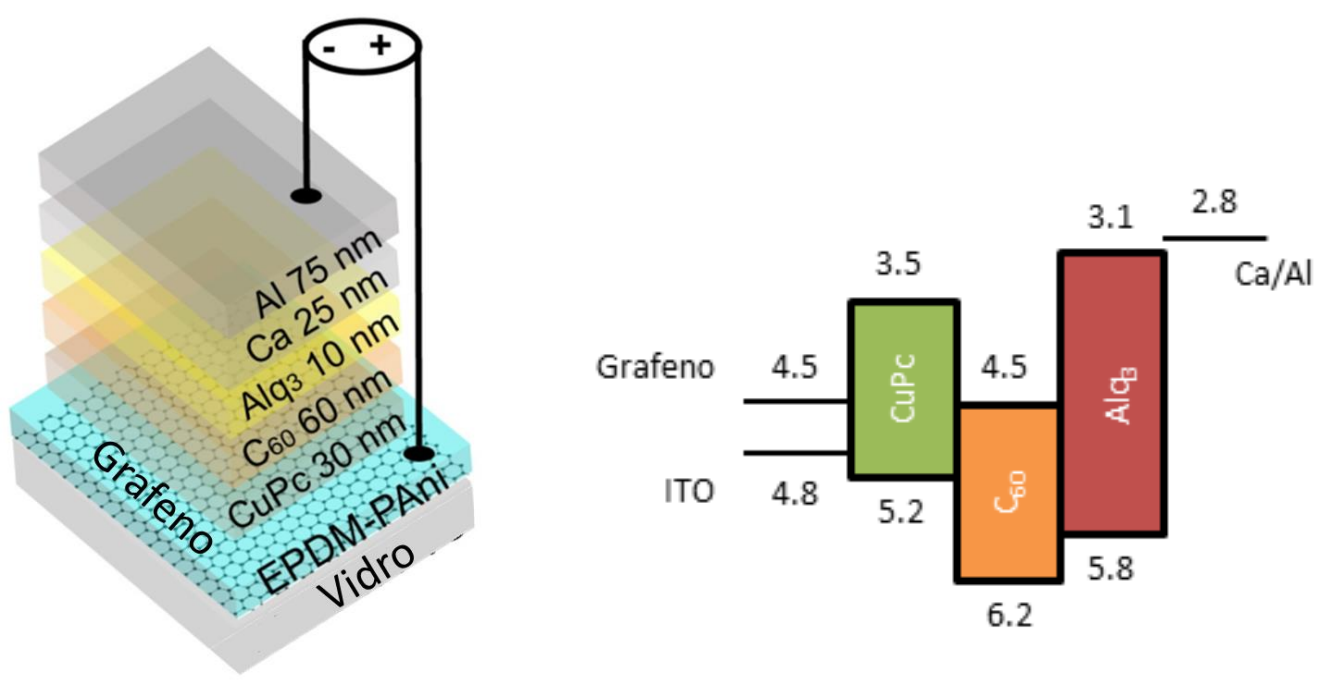

Figura 48: Estrutura física e níveis energéticos do dispositivo fotovoltaico orgânico à base de grafeno, com estrutura tipo Vidro/ eletrodo/ CuPc $(30 \mathrm{~nm}) / \mathrm{C}_{60}(60 \mathrm{~nm}) / \mathrm{Alq}_{3}(10 \mathrm{~nm}) / \mathrm{Ca}(25 \mathrm{~nm}) / \mathrm{Al}(75 \mathrm{~nm})$ 
$\underline{\text { Dispositivos fabricados com substratos poliméricos flexíveis }}$

Conforme mencionado anteriormente, os dispositivos fotovoltaicos orgânicos com substratos poliméricos híbridos foram fabricados em duas etapas. A primeira no Laboratório de Dispositivos Orgânicos (Lador) do Inmetro e a segunda no Laboratório de Opteletônica Orgânica (LOEM) da PUC-Rio. Na sequência serão descritas as estruturas dos dispositivos fotovoltaicos orgânicos fabricados no Lador e em seguida no LOEM.

Os dispositivos foram fabricados e caracterizados de modo a investigar a potencialidade do uso de substratos poliméricos flexíveis em dispositivos fotovoltaicos orgânicos. Para cada substrato polimérico investigado (PVA, PVC e BC) foram fabricadas três diferentes estruturas, como serão descritas abaixo. Dessa forma, visto que foram utilizados três diferentes substratos poliméricos, foram fabricados nove distintos dispositivos a fim de correlacionar o melhor dispositivo flexível, com o dispositivo rígido utilizando vidro, o qual é nossa referência neste trabalho.

Para cada substrato polimérico investigado (PVA, PVC e BC) foram fabricados dispositivos com as seguintes estruturas, onde as espessuras, em parênteses, são expressas em nanômetros:

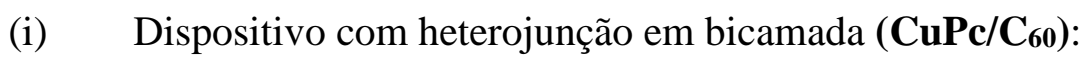
Substrato/ ITO/ CuPc (25)/ C60 (40)/ Alq3 (10)/ Ca (25)/ Al (100);

(ii) Dispositivo com heterojunção em volume (CuPc: $\left.\mathbf{C}_{60}\right)$ : Substrato/ ITO/ $\mathrm{MoO}_{3}(5) / \mathrm{CuPc}(25): \mathrm{C}_{60}(40) / \mathrm{TPBI}(10) / \mathrm{Al}$ (100);

(iii) Dispositivo com heterojunção em bicamada (CuPc/C60): Substrato/ ITO/ $\mathrm{MoO}_{3}$ (5)/ CuPc (25)/ $\mathrm{C}_{60}$ (40)/ TPBI (10)/ $\mathrm{Al}$ (100)

Na Figura 49 são mostrados os níveis energéticos para cada estrutura dos dispositivos fotovoltaicos orgânicos fabricados. 
(i)

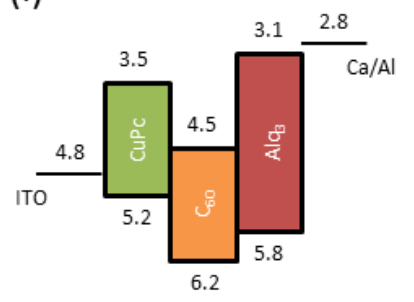

(ii)

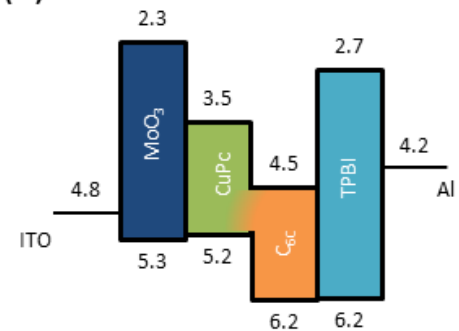

(iii)

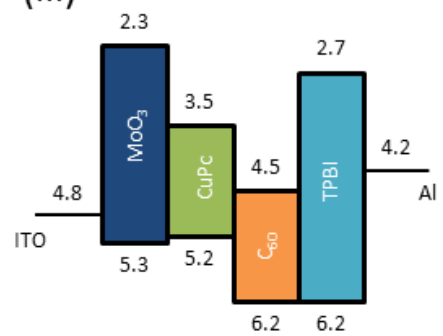

Figura 49: Níveis energéticos dos dispositivos fotovoltaicos orgânicos descrito anteriormente.

Destaca-se que a primeira estrutura (i) é similar à estrutura fabricada utilizando grafeno como eletrodo, a qual foi fabricada e investigada com objetivo de comparar os resultados obtidos.

$\mathrm{Na}$ segunda etapa, as estruturas dos dispositivos fotovoltaicos orgânicos fabricados no Loem/PUC-Rio foram:

(i) Dispositivo com estrutura com heterojunção em tricamada (CuPc/SnPc/C60), sem as camadas intermediárias de $\mathrm{MoO}_{3}$ e TPBI:

Substrato/ ITO/ CuPc (15)/ SnPc (15)/ $\mathrm{C}_{60}(40) / \mathrm{Al}$ (100)

(ii) Dispositivo com estrutura com heterojunção simultaneamente em volume (CuPc:SnPc) e em bicamada (CuPc:SnPc/C60):

Substrato/ ITO/ $\mathrm{MoO}_{3}(5) / \mathrm{CuPc}(15): \mathrm{SnPc}(15) / \mathrm{C}_{60}$ (40)/ TPBI (10)/ Al (100)

(iii) Dispositivo com estrutura com heterojunção em tricamada (CuPc/SnPc/C60):

Substrato/ ITO/ $\mathrm{MoO}_{3}(5) / \mathrm{CuPc}(15) / \mathrm{SnPc}(15) / \mathrm{C}_{60}$ (40)/ TPBI (10)/ Al (100)

Na Figura 50 são mostrados os níveis energéticos para cada estrutura dos dispositivos fotovoltaicos orgânicos fabricados. 
(i)

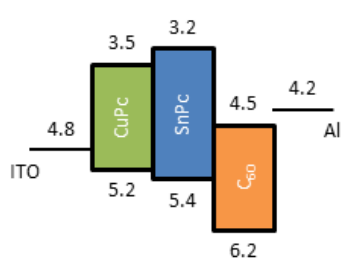

(ii)

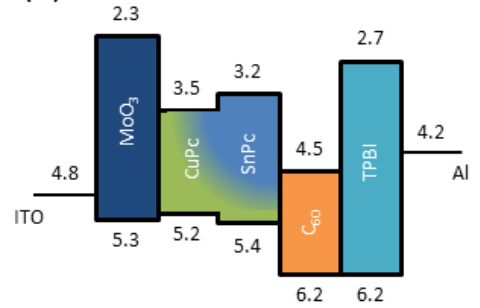

(iii)

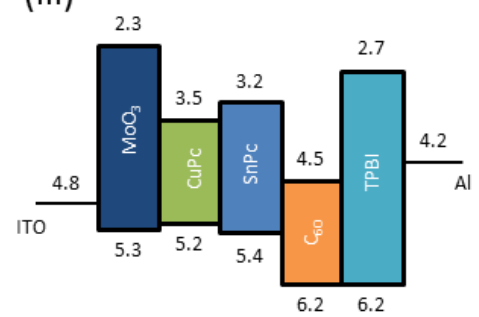

Figura 50: Níveis energéticos dos dispositivos fotovoltaicos orgânicos descrito anteriormente

\section{7}

\section{Técnicas de caracterização dos materiais usados e dos dispositivos fotovoltaicos orgânicos fabricados}

\subsection{1 \\ Caracterização espectroscópica}

\section{Espectroscopia Raman}

A técnica de espectroscopia Raman tem sido comumente usada na caracterização de materiais à base de carbono. Nesta técnica, fótons com determinada frequência incidem sobre o material a ser estudado e são espalhados. A partir da análise da variação da frequência dos fótons que são espalhados no material tem-se informações químicas e estruturais do mesmo.

A partir desta técnica é possível distinguir diferentes alótropos do carbono, principalmente através dos modos vibracionais G, G', D e D', conforme descrito no Capítulo 2. Nesta tese, espectros Raman foram obtidos para avaliar a qualidade (em relação aos possíveis defeitos existentes) e o número de camadas dos filmes de grafeno, além de investigar possíveis modificações estruturais após a deposição da blenda de EPDM-PAni. Para tal, os filmes foram depositados sob substratos de silício com $300 \mathrm{~nm}$ de óxido $\left(\mathrm{Si} / \mathrm{SiO}_{2}\right)$.

As medidas de espectroscopia Raman e microscopia ótica foram feitas usando o espectrômetro Witec Alpha 300 AR equipado com laser de Argônio e Criptônio operando em $233 \mathrm{eV}(532 \mathrm{~nm})$. A potência do laser foi mantida em torno de 0,4 $\mathrm{mW}$ e o tempo de aquisição em $60 \mathrm{~s}$. 
Espectroscopia na Região do Ultravioleta-Visível (UV-Vis)

A espectroscopia UV-VIS (do inglês Ultraviolet-Visible Spectroscopy) é uma técnica para caracterização das propriedades ópticas de um material, na qual se mede a transmissão ótica nas regiões do ultravioleta e visível do espectro eletromagnético. Para isso, a amostra é colocada no caminho ótico da luz, no qual a fração transmitida é medida para cada comprimento de onda $(\lambda)$ aplicado. [88]

A absorção de luz em uma molécula ocorre para comprimentos de onda específicos, pois cada comprimento de onda está associado a uma energia descrita por:

$$
\boldsymbol{E}=\boldsymbol{h v}=\frac{\boldsymbol{h c}}{\lambda}
$$

sendo que a magnitude dessa energia está associada às variações na estrutura eletrônica do material. Assim, quando uma molécula absorve em um determinado comprimento de onda, os elétrons são promovidos para um orbital de mais alta energia.

A absorção pode a ser calculada pela lei de Beer, a partir da transmitância medida. A lei de Beer descreve que um feixe de radiação monocromática com uma potência $\mathrm{P}_{\circ}$ ao incidir em uma amostra tem uma parte de sua intensidade absorvida. Assim, o feixe de radiação que deixa a amostra terá uma potência $\mathrm{P}$ e a quantidade de radiação absorvida pode ser medida de várias maneiras:

$$
\begin{array}{cc}
T=\frac{P}{P_{0}} & \text { Equação } 15 \\
A=\log _{10} \frac{1}{T}=2-\log _{10} \% T & \text { Equação } 16
\end{array}
$$

onde T é a transmitância e A é a absorbância ótica.

Neste caso, os filmes foram depositados sob substratos de vidro com $(1,5 \times 1,5) \mathrm{cm}^{2}$ de área. Neste trabalho foi utilizado o espectrômetro modelo Lambda 950 da marca Perkin-Elmer. Os dados foram coletados na faixa de 350 - $800 \mathrm{~nm}$ com passos de 1,0 nm. 
$\underline{\text { Espectroscopia no Infravermelho com Transformada de Fourier (FTIR) }}$

O FTIR (do inglês Fourier-transform Infrared Spectroscopy) é uma técnica fundamental para a identificação e determinação das propriedades físico-químicas de diferentes materiais, principalmente de grupos funcionais em moléculas orgânicas.

Assim como na absorção, o espectro rotacional das moléculas no infravermelho é formado por linhas espectrais discretas, ao passo que o espectro de vibração molecular é constituído, em geral, por modos vibracionais. As frequências de absorção vibracional das amostras dependem de fatores tais como força de ligação, geometria molecular e massa atômica. Basicamente, as vibrações moleculares podem ser classificadas em dois tipos: vibrações de deformação axial ou estiramento (stretching) e de deformação angular (bending). As deformações axiais são oscilações radiais das distâncias entre os núcleos. Já as deformações angulares envolvem mudanças dos ângulos entre as ligações ou alterações do ângulo entre o plano que contém as ligações e um plano de referência, como na deformação assimétrica fora do plano.

Para as medidas realizadas nesta tese, os espectros foram obtidos à temperatura ambiente, utilizando-se um espectrofotômetro Spectrun GX da Perkin Elmer no modo de transmissão, no intervalo de $500 \mathrm{a} 4000 \mathrm{~cm}^{-1}$.

\subsection{2}

\section{Caracterização elétrica}

$\underline{\text { Resistência de folha pelo método Van der Pauw }}$

Para determinar a resistência de folha $\left(\mathrm{R}_{\mathrm{s}}\right)$ dos filmes fabricados nesta tese foi utilizado o método de Van der Pauw, comumente conhecido como método de quatro pontas.

Neste método de medição, a amostra deve satisfazer algumas condições, tais como ser um filme de espessura homogênea, não podendo apresentar descontinuidades ou falhas, tais como rachaduras e furos, por exemplo. Além disso, os contatos elétricos aplicados sobre a amostra devem ser ôhmicos e, para isso, utilizamos ouro depositado através da técnica de sputtering.

Neste experimento, conforme mostra a Figura 51, uma determinada corrente elétrica é aplicada entre dois contados (pontos A e B) e a diferença de potencial é medida 
entre os outros dois contatos (C e D). Repete-se o processo aplicando a corrente elétrica em outros pontos (B e C) e mede-se a diferença de potencial (D e A). Dessa forma, calcula-se a resistência elétrica através das razões entre as tensões aplicadas e as correntes elétricas medidas na amostra e, por fim, estima-se a resistividade de folha do filme.

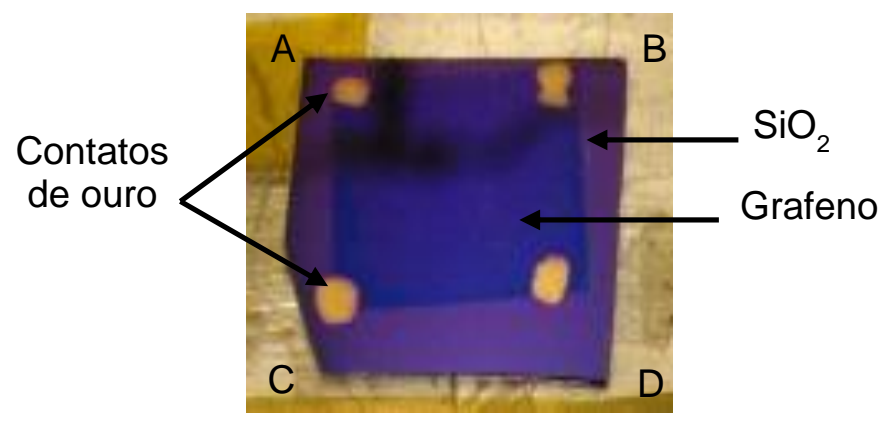

Figura 51: Montagem experimental do método de quatro pontas, utilizada para medir a resistência de folha do grafeno sobre $\mathrm{SiO}_{2}$, utilizando contatos de ouro.

Segundo o método de Van der Pauw, a resistividade elétrica pode ser determinada por [33]:

$$
\rho=\frac{\pi d}{\ln (2)} R
$$

Equação 17

onde $d$ é a espessura do filme e $\mathrm{R}$ é a resistência elétrica determinada pela diferença de potencial entre os pontos C e D e a corrente aplicada entre os pontos A e B da Figura 51. Esta relação pode ser usada quando se tem uma amostra homogênea, que tenha simetria geométrica e seus contatos sejam feitos mantendo essa simetria.

Por fim, a resistência de folha é obtida pela seguinte expressão:

$$
R_{s}=\frac{\rho}{d}
$$

Se considerarmos d =1 na Equação 22, mediremos a resistência de folha ao invés da resistividade elétrica, visto que a espessura é infinitamente menor em relação às demais dimensões do filme, sendo, portanto, a condição ideal para medir materiais bidimensionais.

As medidas foram feitas nos filmes sob substratos de $\mathrm{Si} / \mathrm{SiO}_{2} \mathrm{com}(1,0 \times 1,0) \mathrm{cm}^{2}$ de área. O equipamento usado foi o sistema de medida de Efeito Hall modelo HMS-3000 (ECOPIA). 


\section{$\underline{\text { Curva característica de } \mathrm{J} \times \mathrm{V}}$}

O método padrão para caracterizar a performance dos dispositivos fotovoltaicos orgânicos é por meio de medidas da corrente em função da tensão $(\mathrm{I} \times \mathrm{V})$ do dispositivo sob iluminação padrão de AM 1,5G com intensidade de $100 \mathrm{~mW} / \mathrm{cm}^{2}$ (correspondente a $1 \mathrm{Sol}$ ), de acordo com as recomendações descritas na norma ISO 9845-1:1992. Ao considerar o valor da área do dispositivo, a corrente pode ser escrita como densidade de corrente $(\mathrm{J})$.

As curvas $\mathrm{I} \times \mathrm{V}$ foram obtidas utilizando um multímetro Keithley 2400. Para simular as condições no escuro e sob iluminação, utilizamos uma lâmpada de xenônio (Newport Co.) de $300 \mathrm{~W}$ com filtro AM1.5G como fonte de radiação. A intensidade da radiação $\left(100 \mathrm{~mW} / \mathrm{cm}^{2}\right)$ foi determinada a partir de uma termopilha Newport isenta de calibração (modelo 30589E6).

Os dispositivos fotovoltaicos orgânicos com substratos poliméricos foram avaliados mecanicamente através de sucessivos ciclos de flexão e extensão em determinados diâmetros $(30,25,20$ e 15 mm). As caracterizações optoeletrônicas, obtidas através das curvas características do tipo $\mathrm{J} \times \mathrm{V}$, foram obtidas antes e depois de 10 ciclos de flexão. Para cada diâmetro avaliado, o filme foi mantido durante um minuto flexionado, a fim de garantir a formação de possíveis deformações plásticas ou elásticas no dispositivo.

A Figura 52 ilustra o procedimento usado para fazer os ciclos de flexão e extensão dos dispositivos fotovoltaicos orgânicos. 

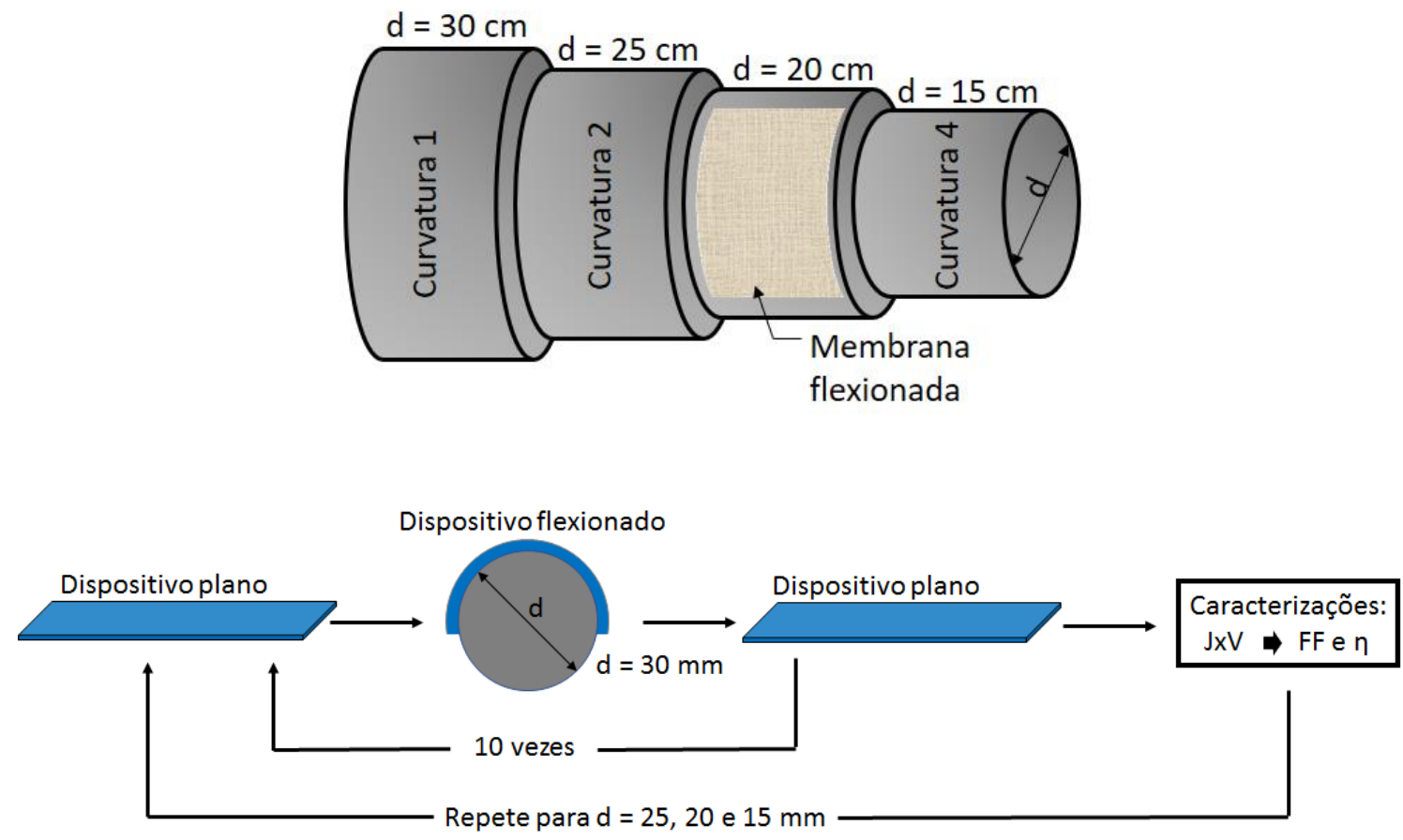

Figura 52: Esquematização do ciclo de flexão e extensão do dispositivo fotovoltaico orgânico com substrato polimérico, flexionado sob diferentes diâmetros e caracterizada a cada 10 ciclos realizados.

\subsection{3}

\section{Caracterização morfológica}

$\underline{\text { Perfilometria }}$

A técnica de perfilometria é usada para avaliar as características morfológicas de uma determinada superfície, como por exemplo o perfil de rugosidade, a partir da análise matemática aplicada a um perfil primário, conforme orienta a ISO 4287:1997 (Especificações Geométricas de Produtos (GPS) -Textura Superficial: Método de Perfil - Termos, definições e parâmetros de rugosidade superficial).

A rugosidade pode ser interpretada como um conjunto de irregularidades morfológicas presentes em uma superfície, no caso em estudo, das superfícies dos filmes finos depositados, os quais influenciam fortemente na eficiência dos dispositivos fotovoltaicos orgânicos.

O conhecimento das imperfeições na superfície dos eletrodos, por exemplo, desempenha papel essencial na fabricação os dispositivos, visto que irregularidades com dimensão da ordem da espessura das demais camadas podem ocasionar curtos circuitos entres estas, por exemplo. 
Conforme ilustra a Figura 53, a rugosidade média aritmética $\left(\mathrm{R}_{\mathrm{A}}\right)$ é definida como a média aritmética dos valores absolutos das ordenadas de afastamento vertical $\left(\mathrm{y}_{\mathrm{i}}\right)$ dos pontos do perfil de rugosidade em relação a linha média, dentro do percurso de medição $l$.

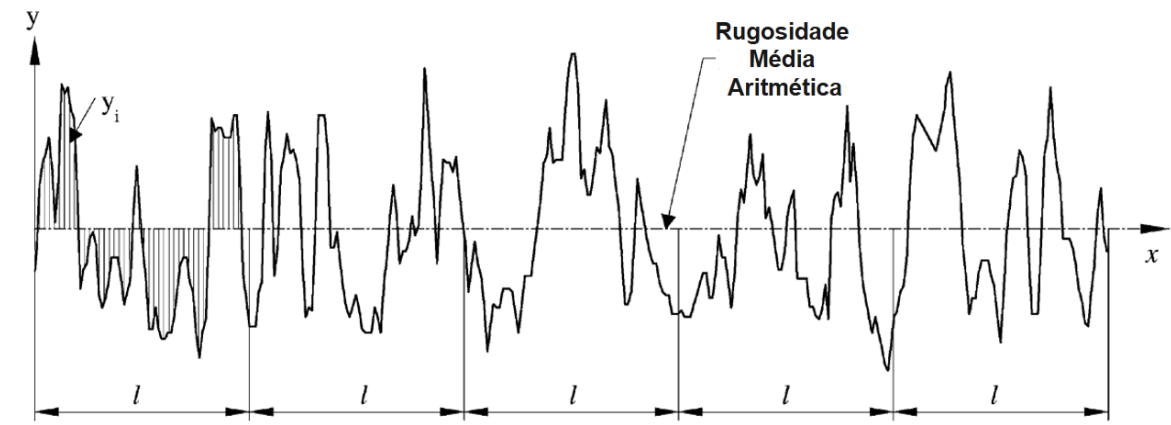

Figura 53: Ilustração do processo de medição da rugosidade de uma determinada superfície, destacando a rugosidade média aritmética (Mean Line). Adaptado de [89].

Dessa forma, $\mathrm{R}_{\mathrm{A}}$ é estimada da seguinte forma:

$$
R_{a}=\frac{1}{l} \int|y(x)| d x
$$

Equação 19

Nesta tese foi utilizado o perfilômetro modelo Dektak6M Stylus Profiler da marca Veeco, equipado com ponta de diamante com $0,7 \mu \mathrm{m}$, para determinar a espessura dos filmes depositados, bem como avaliar a rugosidade das superfícies. As medidas foram feitas em filmes depositados sobre substratos de $\mathrm{Si} / \mathrm{SiO}_{2}$,

Neste processo de medição, a ponta de prova movimenta-se várias vezes sobre a superfície da amostra, a qual fica estática, em faixas de comprimento de $2000 \mu \mathrm{m}$, com resolução espacial de $65 \mathrm{k} \AA$. 


\section{4}

\section{Resultados e discussões}

A seguir serão descritos os resultados alcançados ao longo deste trabalho de doutoramento, bem como as discussões realizadas. Primeiramente serão relatados os resultados para os dispositivos à base de grafeno e em seguida à base dos substratos híbridos.

Antes de descrever os resultados e discussões, mostramos na Figura 54 duas imagens de um dispositivo fotovoltaico orgânico flexível fabricado ao longo deste trabalho, de forma a instigar a curiosidade do leitor perante os resultados obtidos, visto que estes foram satisfatórios para o objetivo proposto.

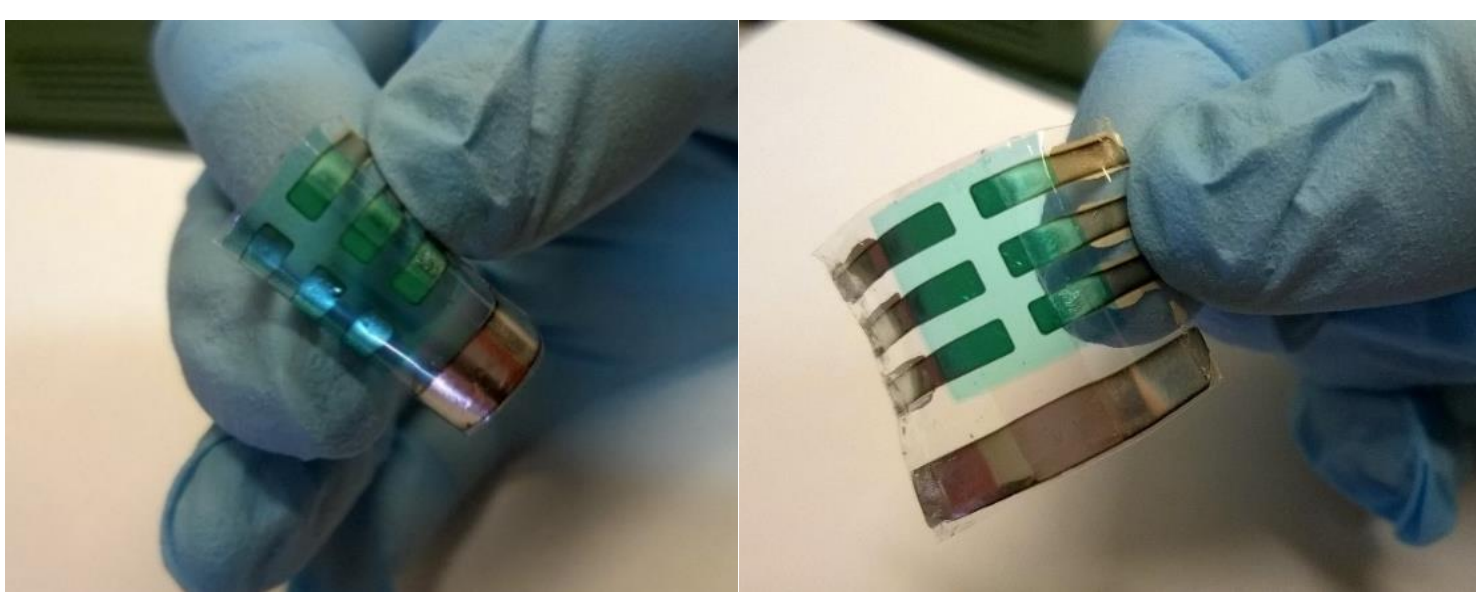

Figura 54: Dispositivos fotovoltaicos orgânicos fabricados sobre um substrato de PVA, destacando sua flexibilidade mecânica. 


\section{1 \\ Dispositivos fotovoltaicos orgânicos à base de filmes de grafeno e grafeno/EPDM-PAni usados como eletrodos condutores e transparentes}

\subsection{1}

\section{Caracterização morfológica dos filmes de grafeno produzidos}

Após o término do processo de crescimento de grafeno pelo método de CVD, realizamos imagens de microscopia ótica com o intuito de verificar a uniformidade do filme crescido, bem como investigar a existência de defeitos em grande escala e de resíduos extrínsecos.

A Figura 55 (a) mostra uma imagem obtida por microscopia ótica de um dos filmes de grafeno transferido pelo método convencional, o qual usa o PMMA como camada de sacrifício. Esta imagem foi propositalmente adquirida em uma região no qual se encontra um buraco no filme de grafeno (mostrando o substrato de $\mathrm{SiO}_{2}$ ), para destacar o contraste entre o óxido de silício e as camadas de grafeno. Podemos observar a existência de áreas claras e escuras, predizendo que há regiões com diferentes números de camadas de grafeno. As manchas verdes correspondem aos resíduos de PMMA remanescentes do processo de transferência.

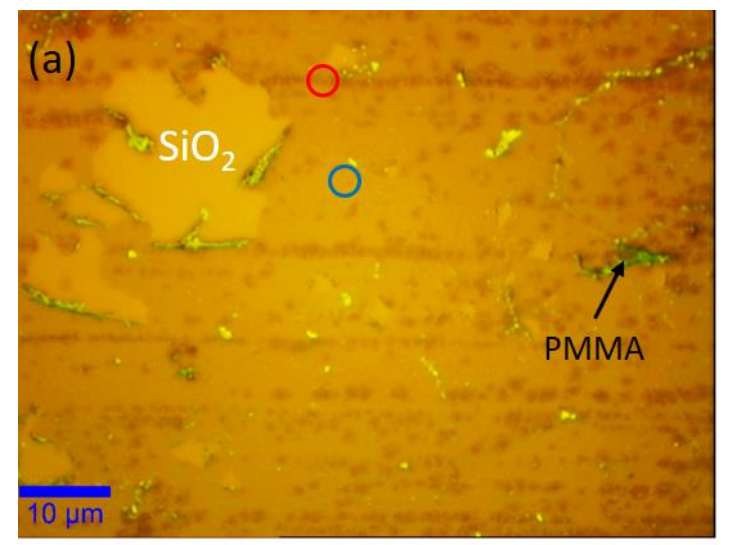

(b)

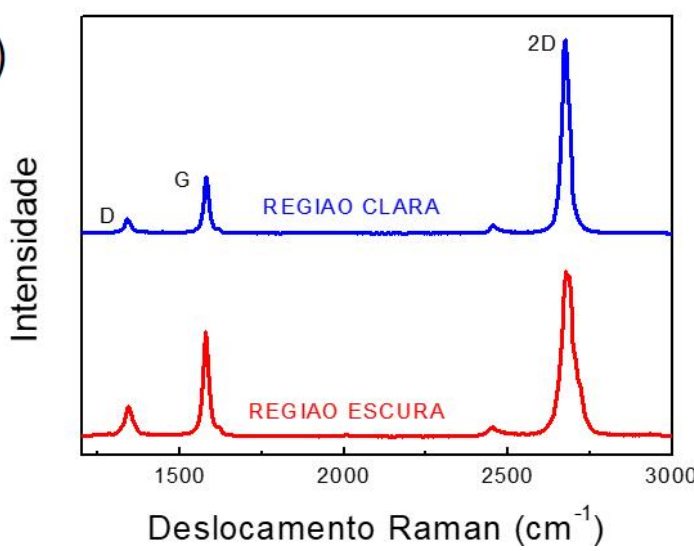

Figura 55: (a) Imagem de microscopia ótica de grafeno sobre $\mathrm{Si} / \mathrm{SiO}_{2}$ mostrando as falhas, os resíduos de PMMA e as regiões de onde foram obtidos os espectros Raman; (b) Espectros Raman das posições marcadas na imagem ótica.

Para comprovar a existência de regiões com diferentes números de camadas de grafeno obtemos espectros Raman em distintas áreas, conforme mostra a Figura 55 (a) e (b): região clara (círculo azul) e em uma região escura (círculo vermelho), ambos na Figura 55 (a). 
Em ambas as regiões analisadas, os espectros Raman apresentaram modos vibracionais característicos do grafeno. A razão entre a intensidade das bandas $G$ e $G$ ' $\left(\mathrm{I}_{\mathrm{G}}, \mathrm{I}_{\mathrm{G}}\right)$ e a largura de meia altura da banda $\mathrm{G}^{\prime}$ permitem distinguir mono e bicamada de grafeno [53, 90-92]. No espectro em azul (região clara) a banda G' ( 2679 $\left.\mathrm{cm}^{-1}\right)$ é praticamente duas vezes maior do que a banda $\mathrm{G}\left(\sim 1586 \mathrm{~cm}^{-1}\right)$, o que é típico de uma monocamada de grafeno. Por outro lado, as regiões mais escuras mostradas na Figura 55 (a) são provavelmente bicamadas de grafeno. Importante destacar que em cada espectro obtido, observa-se um suave pico correspondendo a banda D do grafeno. Esta banda apesar de apresentar baixa intensidade indica que há defeitos no material.

Na Tabela 3 são mostrados os valores das razões $I_{D} / I_{G}$ e $I_{G} / I_{G}$, e da largura de meia altura (FWHM) da banda G' para os espectros Raman mostrados na Figura 55 (b). Assim sendo, com base nas observações anteriores, estimamos que a área global observada seja essencialmente composta de mono e bicamadas de grafeno.

Tabela 3: Valores das razões $I_{D} / I_{G}$ e $I_{G}, / I_{G}$ e, a FWHM da banda G' para os espectros Raman mostrados na Figura 55 (b).

\begin{tabular}{cccc} 
& $\mathbf{I}_{\mathbf{D}} / \mathbf{I}_{\mathbf{G}}$ & $\mathbf{I}_{\mathbf{G}}, \mathbf{I}_{\mathbf{G}}$ & FWHM $\left(\mathbf{c m}^{\mathbf{- 1}}\right)$ \\
\hline Região clara & 0,29 & 3,3 & 27 \\
Região escura & 0,30 & 1,5 & 44
\end{tabular}

\subsection{2}

Caracterizações elétricas e óticas dos filmes de EPDM-PAni e grafeno/EPDM-PAni

Correlação entre resistência de folha, transmitância ótica e quantidade de PAni em EPDM

Diversas blendas foram sintetizadas com diferentes quantidades de PAni em EPDM até atingirmos as melhores condições elétricas e óticas possíveis. Os filmes foram depositados em substratos de óxido de silício e vidro para a realização de medidas de resistência de folha, transmitância ótica e espectroscopia Raman.

A Figura 56 mostra o gráfico da resistência de folha da blenda de EPDM-PAni em função da porcentagem em massa de PAni. Observa-se uma queda exponencial da resistência de folha $\left(\mathrm{R}_{\mathrm{s}}\right)$ em relação à quantidade de PAni na blenda de EPDM-PAni. A caracterização ótica dos filmes de EPDM-PAni foi realizada utilizando o método de transmitância por UV-Vis. 


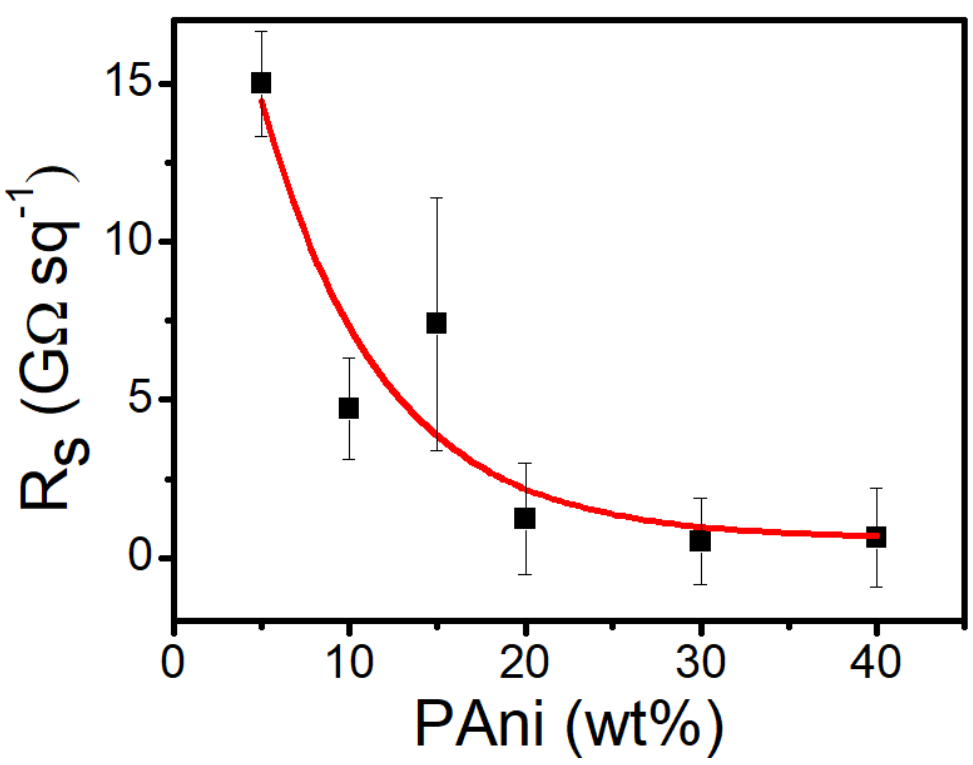

Figura 56: Resistência de folha da blenda de EPDM-PAni em função de diferentes quantidades de PAni, em peso.

A Figura 57 mostra as medidas de transmitância ótica da blenda de EPDM-PAni com diferentes porcentagens em massa de PAni.

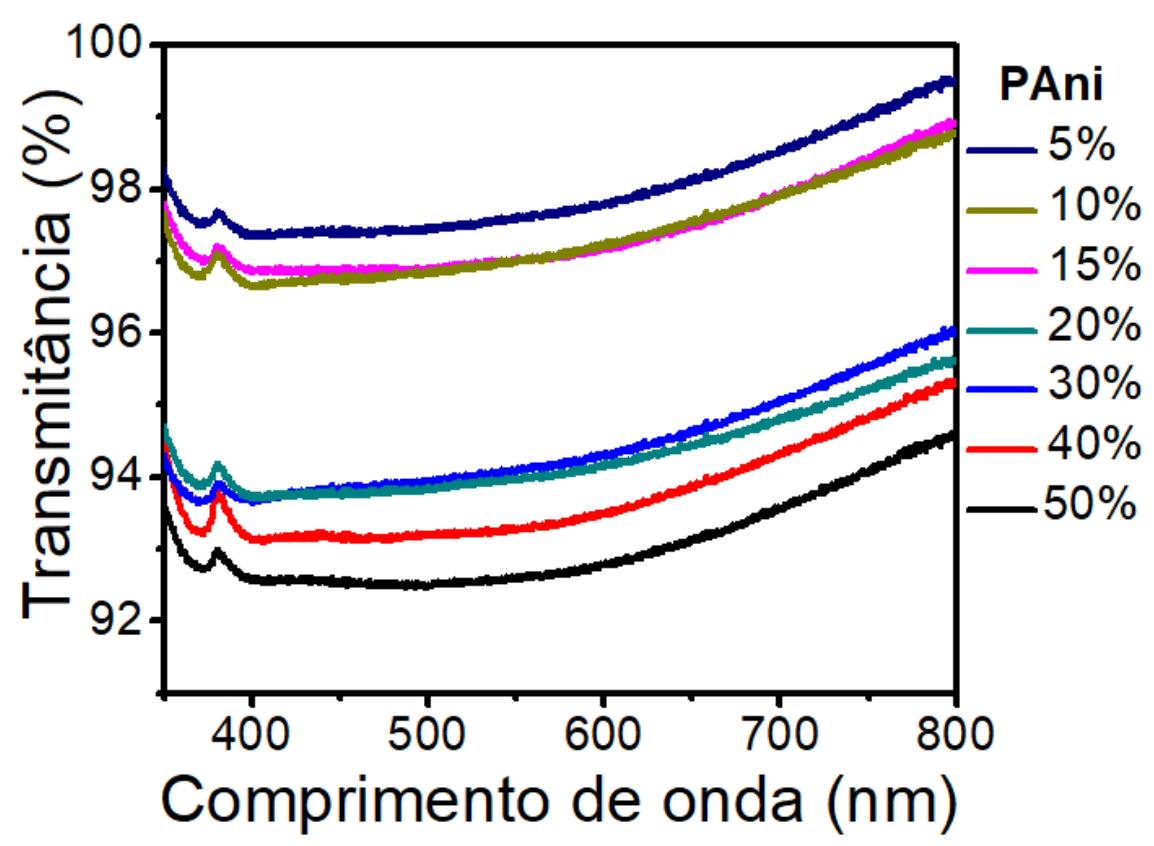

Figura 57: Medidas de UV-Vis da blenda de EPDM-PAni com diferentes porcentagens em massa de PAni $(5-50 \mathrm{wt} \%)$.

Como pode ser observado, todos os filmes têm transmitância ótica acima de $92 \%$ para a faixa de comprimento de onda de 350 até $800 \mathrm{~nm}$. Contudo, destacam-se os filmes 
com baixa quantidade de PAni (em torno de 5 a $15 \mathrm{wt} \%$ de PAni) por apresentarem transmitância em torno de $97 \%$ em 550nm.

Todavia, ao correlacionarmos os valores de resistência de folha, da transmitância ótica e da concentração de PAni em EPDM, observa-se conforme a Figura 58 que a melhor condição experimental possível, ocorreu na concentração entre 30 e 40wt\% de PAni em EPDM. Neste trabalho, decidimos utilizar 30wt\% de PAni em EPDM como sendo o melhor compromisso entre os diferentes requisitos.

Atenta-se que na Figura 58 é mostrada a transmitância ótica em relação à concentração de PAni, juntamente ao inverso da resistência de folha (condutância de folha), também em relação à PAni. Esta representação foi escolhida para que todas as propriedades sejam diretamente proporcionais entre si.

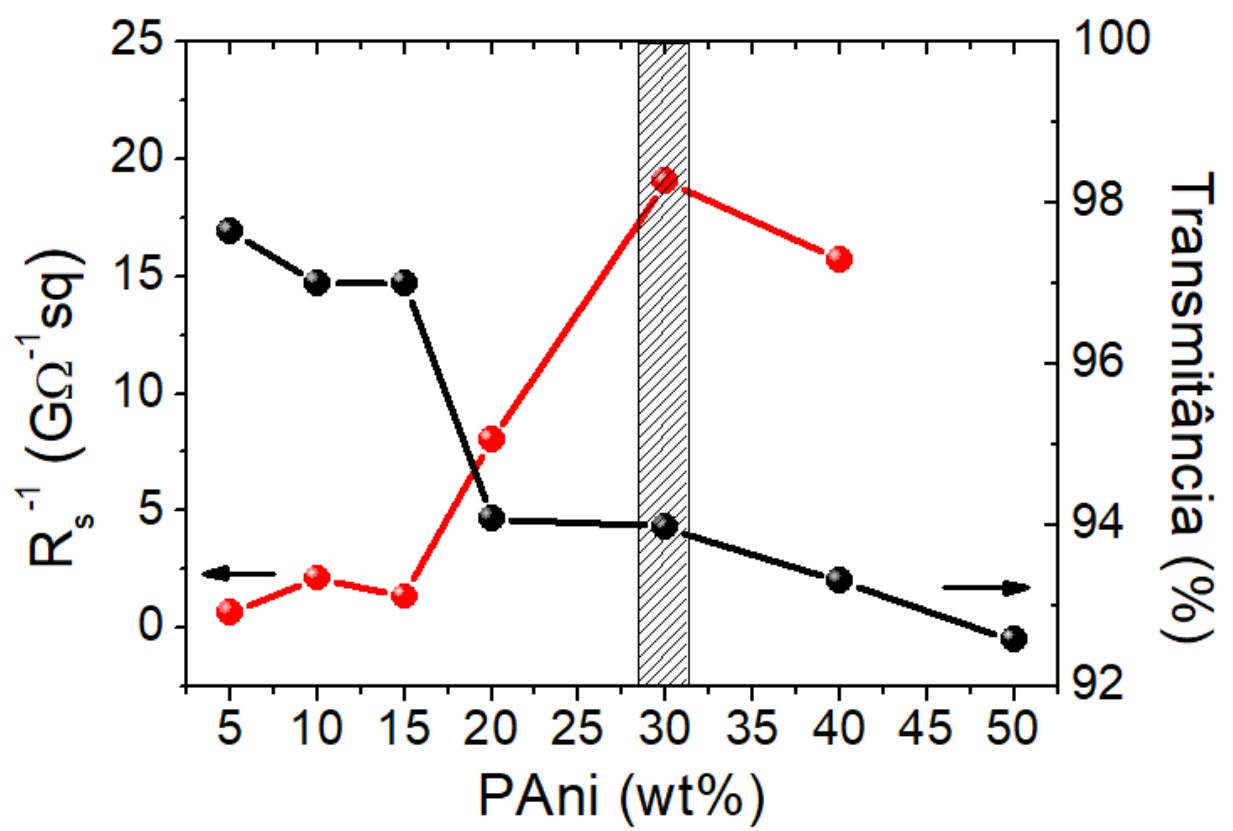

Figura 58: Relação entre condutância de folha $\left(\mathrm{R}_{\mathrm{S}}{ }^{-1}\right)$ e transmitância ótica em relação à concentração de PAni em EPDM.

Correlação entre resistência de folha, transmitância ótica e processo de filtragem da blenda de EPDM-PAni

Uma vez definida a porcentagem de PAni em EPDM, faz-se necessário avaliar a dependência do filme final em relação ao processo de filtragem. O processo de filtragem, após o processo de síntese da solução de EPDM-PAni, é uma etapa extremamente relevante por sua dependência com a rugosidade final do filme que será depositado. A 
Tabela 5 mostra os resultados obtidos para resistência de folha $\left(R_{S}\right)$, rugosidade $\left(R_{A}\right)$ e transmitância ótica (T) dos filmes de grafeno/EPDM-PAni, após o processo de filtragem com diferentes porosidades da solução percursora com $30 \%$ de PAni em EPDM. Para isso, foram utilizados filtros com porosidades de 450, 220 e $100 \mathrm{~nm}$.

Tabela 4: Relação entre os valores de $\mathrm{R}_{\mathrm{S}}, \mathrm{R}_{\mathrm{A}}$ e $\mathrm{T}$ obtidos para diferentes porosidades utilizadas no processo de filtragem da solução de EPDM-PAni.

\begin{tabular}{cccc}
\hline Amostra - porosidade do filtro & $\mathbf{R s}\left(\mathbf{k} \boldsymbol{\Omega} \mathbf{s q}^{-\mathbf{1}}\right)$ & $\mathbf{R A}(\mathbf{n m})$ & $\mathbf{T}(\boldsymbol{\%})$ \\
\hline Grafeno/EPDM-PAni - 450 nm & $1.0 \pm 0.1$ & $21.0 \pm 6.0$ & 95.0 \\
Grafeno/EPDM-PAni - 220 nm & $1.6 \pm 0.3$ & $20.1 \pm 7.7$ & 96.3 \\
Grafeno/EPDM-PAni - 100 nm & $2.1 \pm 0.2$ & $19.4 \pm 13.3$ & 96.8 \\
\hline
\end{tabular}

Verificamos que a resistência de folha $\left(\mathrm{R}_{\mathrm{S}}\right)$ das amostras aumenta com a diminuição da porosidade do filtro utilizado. Este fato já era esperado devido à diminuição da quantidade de PAni, resultante do processo de filtragem da solução original. Em contrapartida, a transmitância ótica dos filmes decresce, mesmo que sutilmente, em relação ao aumento da porosidade dos filtros utilizados.

Por fim, de acordo com os resultados obtidos, observamos que a melhor condição experimental da síntese das blendas de EPDM-PAni, para aplicação em dispositivos fotovoltaicos orgânicos, ocorre com a concentração de 30wt\% de PAni em EPDM, com solução filtrada na porosidade de $220 \mathrm{~nm}$. A partir de então, esta condição de síntese será chamada de "condição otimizada de EPDM-PAni".

Para constatarmos a existência de ambos os polímeros percursores na condição otimizada de EPDM-PAni, obtivemos imagens de microscopia ótica destacando a existência de diferentes fases, como mostra a Figura 59 (a). Para garantir que estas distintas fases são originadas dos polímeros EPDM e PAni, não sendo, portanto, materiais extrínsecos, utilizamos a técnica de espectroscopia Raman para a identificação das respectivas fases.

Os espectros mostrados nas Figuras 59 (b) e (c) foram capturados nas respectivas posições indicadas na Figura 59 (a). Nestes espectros é possível observar os modos vibracionais típicos de cada polímero: do EPDM, com modos entre 3150 e $2750 \mathrm{~cm}^{-1}$ e da PAni entre 1700 e $1000 \mathrm{~cm}^{-1}$. 

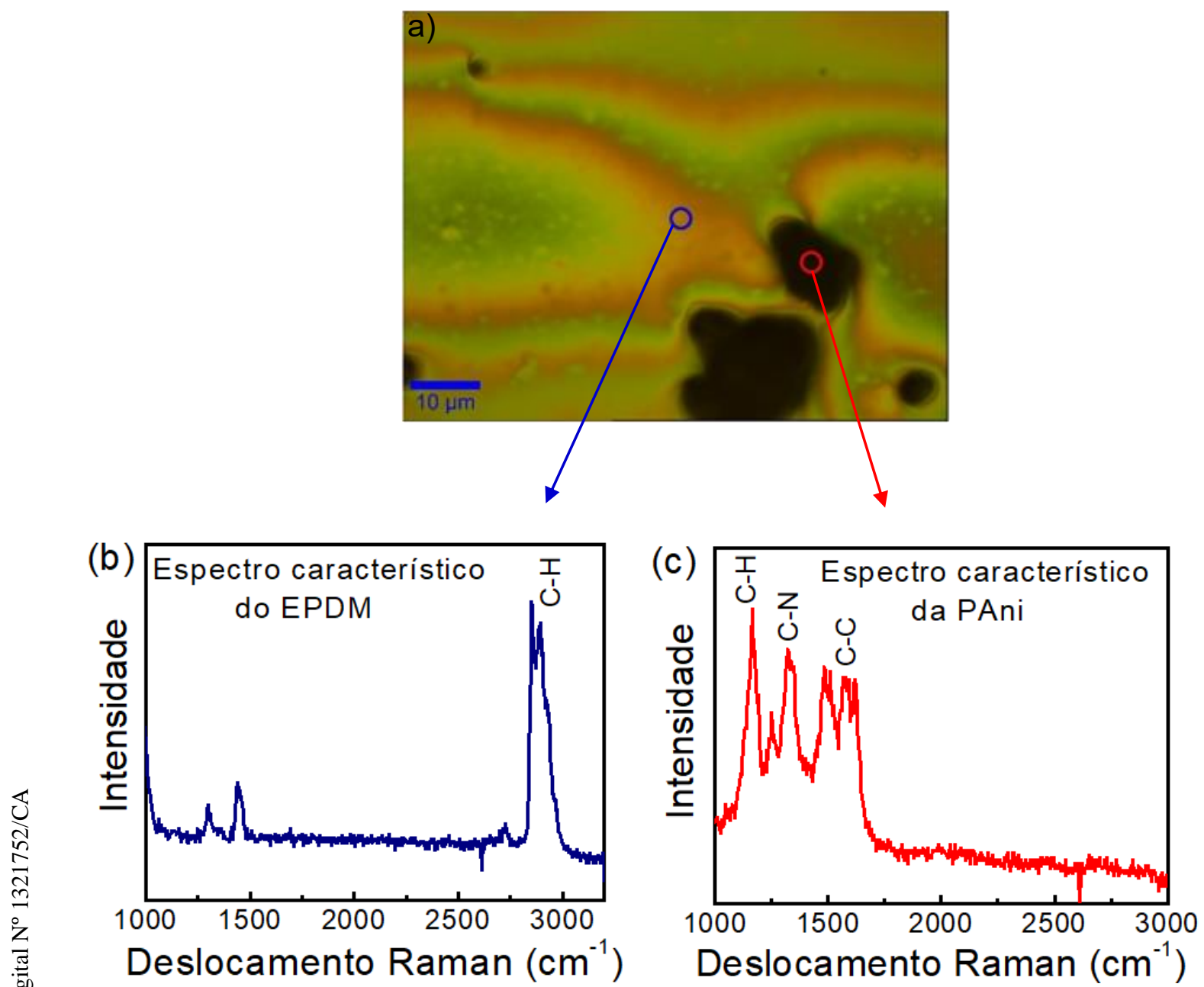

Figura 59: (a) Imagem obtida por microscopia ótica identificando duas distintas fases, as quais compões a blenda de EPDM-PAni. (b) e (c) Espectros Raman coletados separadamente nas regiões identificadas na imagem ótica.

A partir destes resultados, observamos que os cristais de PAni estão dispersos heterogeneamente na blenda, indicando que as propriedades descritas até o momento são de caráter macroscópico. A seguir será descrito o processo realizado para aderir o grafeno à blenda de EPDM-PAni.

\subsection{3}

\section{Processo de transferência do grafeno utilizando blenda de EPDM-PAni}

Esta etapa da tese, por tratar-se de materiais e métodos caberia perfeitamente no referido capítulo (Capítulo 3 - Materiais e métodos). Contudo, decidimos colocá-lo neste para destacar esta etapa da pesquisa realizada e, principalmente, pelo fato deste método desenvolvido também ser um resultado deste doutoramento. 
Diferentemente do processo tradicional de transferência de grafeno, no qual utilizase o PMMA como suporte mecânico, sendo este removido ao final do processo, neste novo método a camada depositada sobre o grafeno não é removida. Esta fará parte do filme final, sobre a qual o dispositivo fotovoltaico orgânico será fabricado. Para isso, utiliza-se a blenda de EPDM-PAni, a qual foi sintetizada conforme descrito no Capítulo 3 - Materiais e métodos. Este processo de síntese e transferência é esquematizado na Figura 60.

(a) Polin

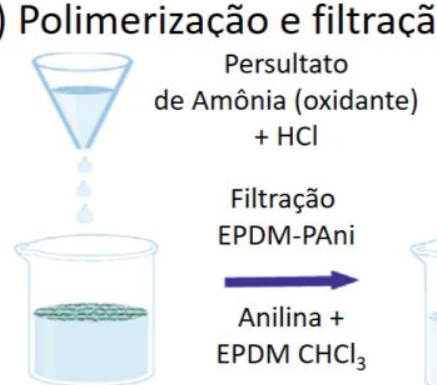

(c) PVC/Grafeno/EPDM-PAni
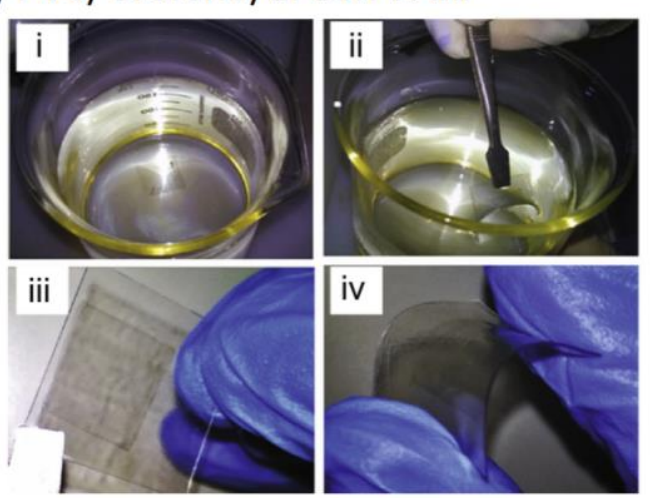

(b) Transferência do Grafeno
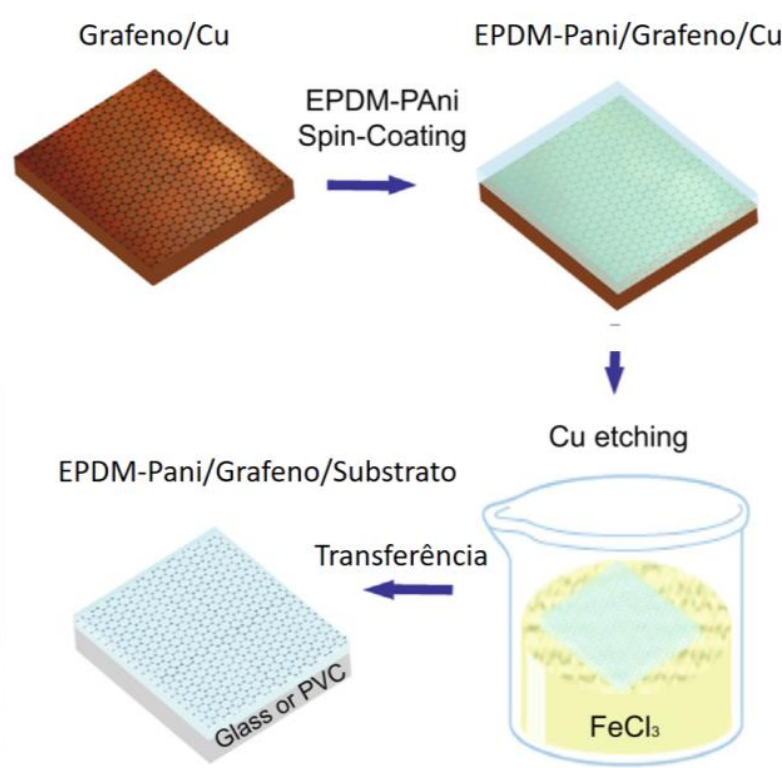

Figura 60: Esquematização do processo de transferência: (a) Síntese da solução de EPDM-PAni; (b) Deposição por centrifugação de solução de EPDM-PAni sobre a folha de grafeno/Cu, seguido da corrosão do $\mathrm{Cu}$ através da solução de $\mathrm{FeCl}_{3}$ e transferência para o substrato final (vidro ou polímero flexível); (c) Imagens do grafeno/EPDM-PAni flutuando em água (imagens i e ii) e depois, transferidas para um substrato flexível de policloreto de vinila (PVC) (imagens iii e iv).

Após o processo de síntese e filtragem da solução de EPDM-PAni, esta é depositada sobre a superfície do grafeno, utilizando a técnica de centrifugação (spin coating). Essa etapa resulta em uma disposição de camadas tipo sanduíche de $\mathrm{Cu} / \mathrm{grafeno} / \mathrm{EPDM}-\mathrm{PAni}$.

A técnica de spin coating é um método de deposição de filmes finos a partir de soluções de materiais poliméricos. O filme é depositado através da aplicação da solução sobre um substrato, que gira em torno do seu eixo perpendicular à superfície. O efeito da rotação resulta na evaporação do solvente da solução e na formação de um filme fino 
sólido. Para esta técnica o tempo, a velocidade rotacional e a viscosidade da solução são parâmetros que influenciam drasticamente a qualidade do filme.

Para os filmes de EPDM-PAni apresentarem qualidade compatível com a sua futura aplicação, previamente realizamos diversos testes, variando tanto a velocidade, quanto o tempo de rotação. A melhor condição encontrada para deposição da solução de EPDMPAni ocorreu na velocidade de $3000 \mathrm{rpm}$, durante $1 \mathrm{~min}$.

Em seguida, o conjunto $\mathrm{Cu} / \mathrm{grafeno} / \mathrm{EPDM}-\mathrm{PAni}$ é aquecido à $50^{\circ} \mathrm{C}$ durante $1 \mathrm{~h}$ para promover a evaporação do solvendo residual, bem como auxiliar na homogeneização do filme de EPDM-PAni depositado.

Por fim, os demais passos do processo de transferência são iguais ao do processo de transferência convencional, no qual o conjunto Cu/grafeno/EPDM-PAni é flutuado em uma solução de $\mathrm{FeCl}_{3}(1 \mathrm{~mol} / \mathrm{L})$, com o objetivo de promover a corrosão do substrato de cobre, seguido do processo de adesão mecânica ao substrato desejado, tal como vidro ou substratos poliméricos, o qual é o caso mostrado na Figura 49, formando um substrato funcionalizado de PVC/grafeno/EPDM-PAni.

\subsection{4 \\ Comparação entre os filmes de grafeno e grafeno/EPDM-PAni}

Conforme descrito previamente, este novo método de transferencia acarreta em uma camada adicional ao substrato, no caso o EPDM-PAni. Ou seja, este processo é benéfico por não precisar remover a camada de PMMA, o que resulta em residuos indesejaveis no filme de grafeno, mas adiciona uma nova camada.

$\mathrm{O}$ intuito nesta etapa é investigar os efeitos desta camada aditiva nas propriedades do grafeno, visto que este é o responsavel pela condução elétrica do filme. A Figura 61 compara os espectros Raman do filme de grafeno transferido pelo método tradicional usando PMMA com o filme de grafeno/EPDM-PAni. Nesta comparação é possivel observar os modos vibracionais típicos do grafeno em ambas amostras, representados pelas bandas D, G e G' e no caso do grafeno/EPDM-PAni também observa-se bandas em torno de 2928 e $2852 \mathrm{~cm}^{-1}$, característicos do EPDM e em torno de 1520 e $1650 \mathrm{~cm}^{-1}$ característicos da PAni. 


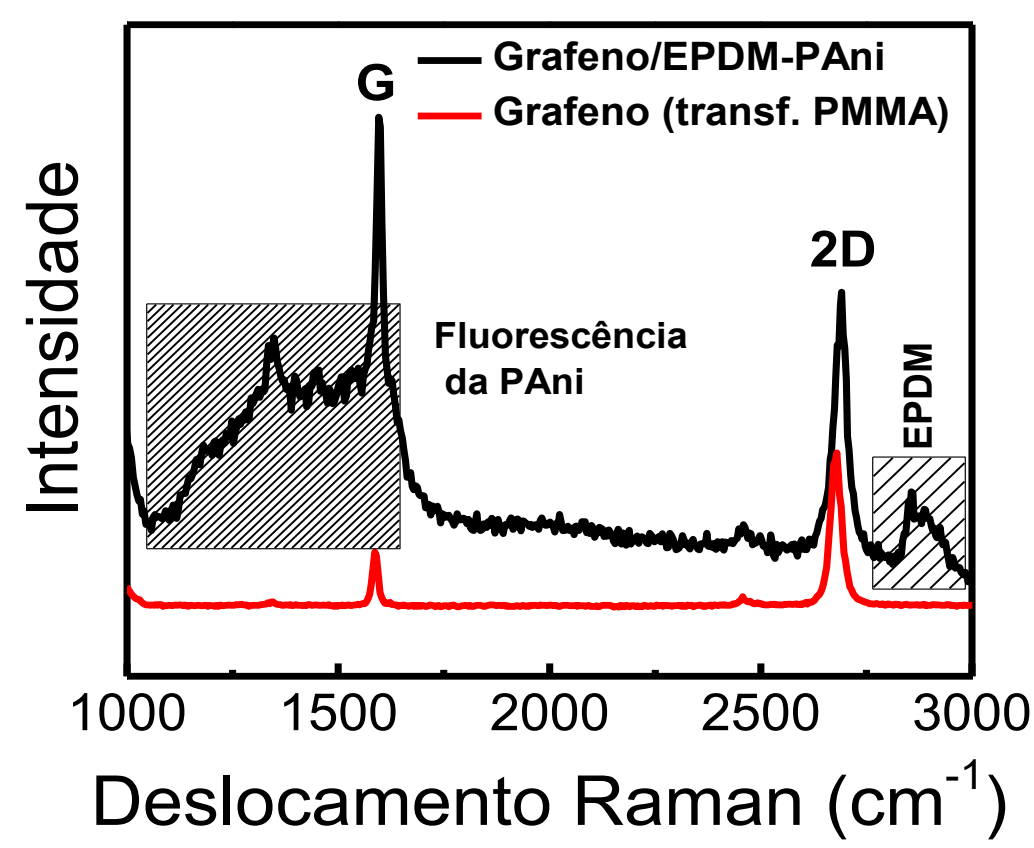

Figura 61: Comparação entre os espectros Raman obtidos em filme de grafeno transferido com PMMA e em filme de grafeno/EPDM-PAni;

A Tabela 5 apresenta os resultados de resistência de folha $\left(\mathrm{R}_{\mathrm{S}}\right)$, transmitância ótica (T) e rugosidade $\left(\mathrm{R}_{\mathrm{A}}\right)$ para as amostras de grafeno (transferido convencionalmente com PMMA), grafeno/EPDM-PAni e apenas a blenda de EPDM-PAni, para efeitos comparativos.

Tabela 5: Comparação entre os principais parâmetros que afetam os dispositivos fotovoltaicos.

\begin{tabular}{cccc}
\hline Amostra & $\mathbf{R s}\left(\mathbf{k} \boldsymbol{\Omega} \mathbf{~ s q}^{\mathbf{- 1}}\right)$ & $\mathbf{T}(\boldsymbol{\%})$ & $\mathbf{R}_{\mathbf{A}}(\mathbf{n m})$ \\
\hline EPDM-PAni & $(4.5 \pm 0.6) 10^{5}$ & 99.0 & $14.0 \pm 4.9$ \\
Grafeno (PMMA) & $2.4 \pm 0.1$ & 95.5 & $18.0 \pm 8.0$ \\
Grafeno/EPDM-PAni & $1.6 \pm 0.3$ & 96.3 & $20.1 \pm 7.7$ \\
\hline
\end{tabular}

Os filmes de grafeno transferidos com PMMA apresentaram resistência de folha média de $(2,4 \pm 0,1) \mathrm{k} \Omega \mathrm{sq}^{-1}$. Os filmes de grafeno/EPDM-PAni apresentaram menor resistência de folha.

A partir dos resultados apresentados, observa-se que a transmitância ótica dos filmes está acima de 95\%, sendo compatíveis para aplicações em dispositivos fotovoltaicos orgânicos. Da mesma forma, os valores de rugosidade foram similares entre as amostras, considerando o desvio padrão obtido. 
Com relação aos valores de resistência de folha, observa-se que esta diminui em torno de $66 \%$ para o filme de grafeno/EPDM-PAni em relação ao filme de grafeno, mesmo que apenas o EPDM-PAni apresente uma resistência de folha altíssima.

Este resultando, mesmo sendo curioso e inesperado, passa a fazer sentido ao observarmos os espectros Raman obtidos em regiões distintas em um mesmo filme de grafeno/EPDM-PAni. A Figura 62 ilustra representativamente o filme de grafeno/EPDMPAni indicando regiões específicas, nas quais foram adquiridos os espectros Raman mostrados nesta mesma figura.
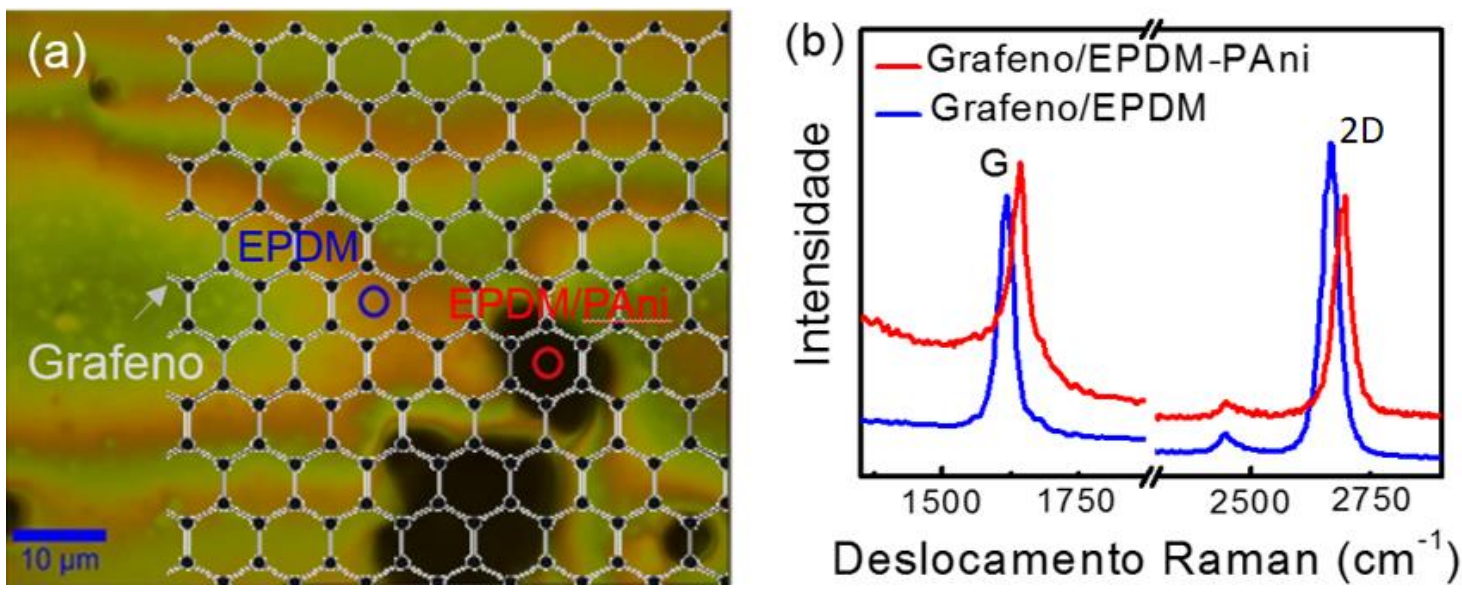

Figura 62: Comparação entre as posições dos modos vibracionais G e G' obtidos em duas posições da amostra de grafeno/EPDM-PAni.

O espectro em vermelho da Figura 62 (b) representa o espectro Raman obtido sobre um agregado de PAni, enquanto o espectro em azul, obtido do mesmo eletrodo, é medido sobre uma região sem o agregado de PAni. A partir desta comparação, observa-se um forte deslocamento para direita $\left(\sim 16 \mathrm{~cm}^{-1}\right)$ de ambas as bandas $\mathrm{G} \mathrm{e} \mathrm{G}^{\prime}$, indicando efeitos de dopagem do tipo n ou p no grafeno [93]. Observamos que esta dopagem não é homogênea na amostra, como esperado para um material tipo semi-metal. A dopagem fica localizada próxima da interface grafeno/PAni.

Em concordância com a nossa interpretação para este tipo de dopagem, tem sido relatado na literatura que a heterogeneidade (tamanho de grãos, ondulação ou número de camadas) em materiais bidimensionais leva a este tipo de comportamento [94, 95].

Finalmente, embora as mudanças observadas entre os espectro Raman do grafeno dopado com PAni não possam indicar claramente o tipo de portador de carga (tipo n ou p), devido à baixa concentração de dopagem, trabalhos anteriores demonstraram que o nitrogênio contido na estrutura da PAni deve agir como um dopante do tipo n [96]. 
$\mathrm{Na}$ sequência, foi utilizado a técnica de espectroscopia FTIR na tentativa de identificar em maiores detalhes os mecanismos de dopagem do grafeno com a PAni. Neste estudo, esta técnica foi utilizada para identificar e avaliar as possíveis modificações induzidas ao eletrodo de grafeno/EPDM-PAni, em virtude da transferência do grafeno ter sido realizada utilizando a blenda de EPDM-PAni.

A Figura 63 apresenta os espectros obtidos a partir da técnica de FTIR de filmes finos de grafeno/EPDM-PAni, EPDM e PAni, com comprimento de onda variando de 500 a $4000 \mathrm{~cm}^{-1}$.

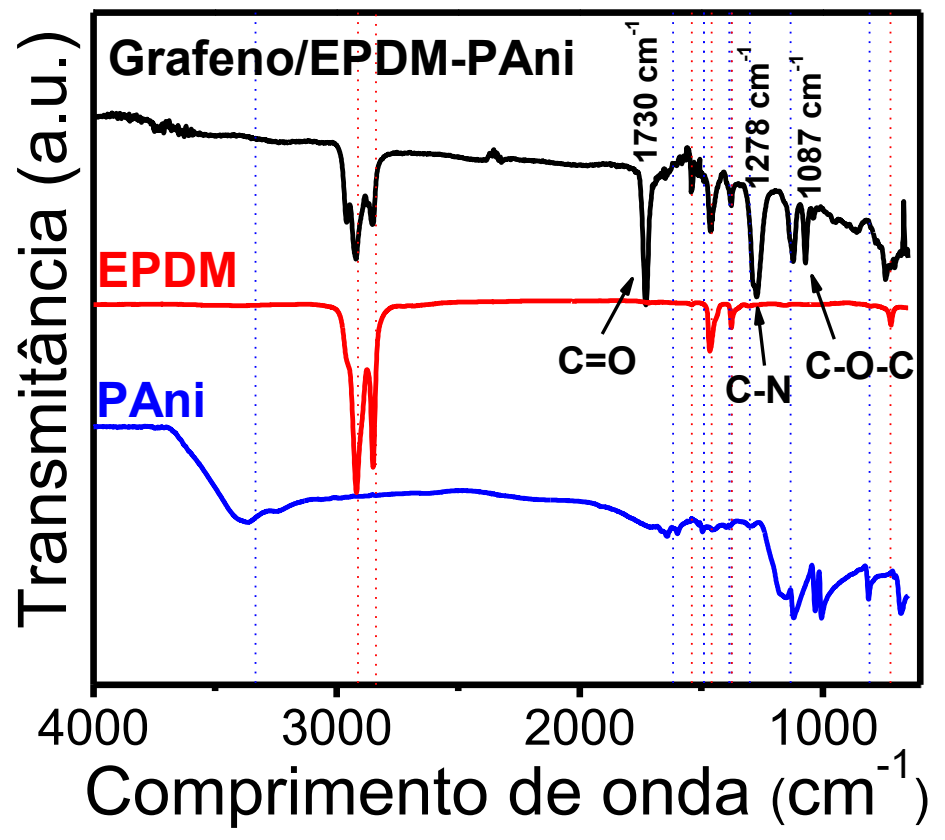

Figura 63: Espectros de FTIR obtidos em filmes de grafeno/EPDM-PAni, EPDM e PAni.

Observa-se na Figura 63 que o espectro do EPDM exibe os modos vibracionais característicos, conforme identificados a seguir [97, 98]:

- 2923 e $2853 \mathrm{~cm}^{-1}$ - associados à ligação $\mathrm{CH}$

- $1542 \mathrm{~cm}^{-1}$ - associado à ligação $\mathrm{C}=\mathrm{C}$ do segmento de etileno (modo de fraca intensidade, mas presente no espectro)

- $1457 \mathrm{~cm}^{-1}$ - associado à ligação $\mathrm{CH}_{2}$ do segmento de propileno

- $1376 \mathrm{~cm}^{-1}$ - associado à ligação $\mathrm{CH}_{3}$ do segmento de propileno

- $725 \mathrm{~cm}^{-1}$ - associado à ligação $\mathrm{CH}_{2}$ do segmento de etileno

Ainda na Figura 63, observa-se que o espectro obtido da PAni indicou os seguintes modos vibracionais $[99,100]$ : 
- $3239 \mathrm{~cm}^{-1}$ - associado à ligação $\mathrm{NH}$

- $1598 \mathrm{~cm}^{-1}$ - associado aos anéis quinoide

- $1496 \mathrm{~cm}^{-1}$ - associado à ligação $\mathrm{C}=\mathrm{C}$ do anel benzênico

- $1457 \mathrm{~cm}^{-1}$ - associado à ligação $\mathrm{CH}_{2}$

- $1381 \mathrm{~cm}^{-1}$ - associado à ligação $\mathrm{CH}_{3}$

- $1302 \mathrm{~cm}^{-1}$ - associado à ligação C-N

- $1121 \mathrm{~cm}^{-1}$ - associado à ligação N-H

- $812 \mathrm{~cm}^{-1}$ - associado às ligações Q-H e =Q-, onde Q é um grupo quinon

Por fim, no espectro da heterojunção de grafeno/EPDM-PAni observa-se claramente a presença do EPDM e da PAni, através dos seus modos vibracionais característicos. Cita-se, no entanto, que o material utilizado para a obtenção do espectro individual do EDPM não sofreu o processo de funcionalização, ao passo que o EPDM do filme de grafeno/EPDM-PAni foi funcionalizado para maximizar sua compatibilidade com a PAni, a qual é hidrofílica.

Referente ao espectro de grafeno/EPDM-PAni, os modos vibracionais em 1087 e $1730 \mathrm{~cm}^{-1}$ merecem destaque por não estarem presentes nos espectros do EPDM e da PAni individualmente. O primeiro modo é associado à ligação C-O-C, enquanto o último ao $\mathrm{C}=\mathrm{O}$, ambos no segmento de etileno do EPDM. Estas ligações têm origem no processo de oxigenação dos grupos funcionais em decorrência da funcionalização do EPDM, na qual é utilizado anidrido maleico e peróxido de benzoíla, conforme descrito no Capítulo 3 - Materiais e métodos.

De forma semelhante analisa-se o modo vibracional em $1278 \mathrm{~cm}^{-1}$, o qual não havia sido observado, tanto no espectro do EPDM, quanto no da PAni individualmente, sugerindo que este modo tenha origem na interação entre o grafeno e a PAni, principalmente pelo fato deste modo vibracional estar associada a uma ligação tipo C-N, a qual já tem sido relatada na literatura [99, 101, 102].

Logo, sugere-se que a PAni atua diretamente no mecanismo de dopagem do filme de grafeno, melhorando suas propriedades de transporte de carga. A Figura 64 ilustra a estrutura polimérica do EPDM-PAni e a estrutura do grafeno, bem como o mecanismo de dopagem de nitrogênio oriundo da PAni no grafeno, onde: bolas de cinza correspondem aos átomos de carbono, as bolas azuis correspondem aos átomos de nitrogênio e as bolas brancas correspondem aos átomos de hidrogênio. 

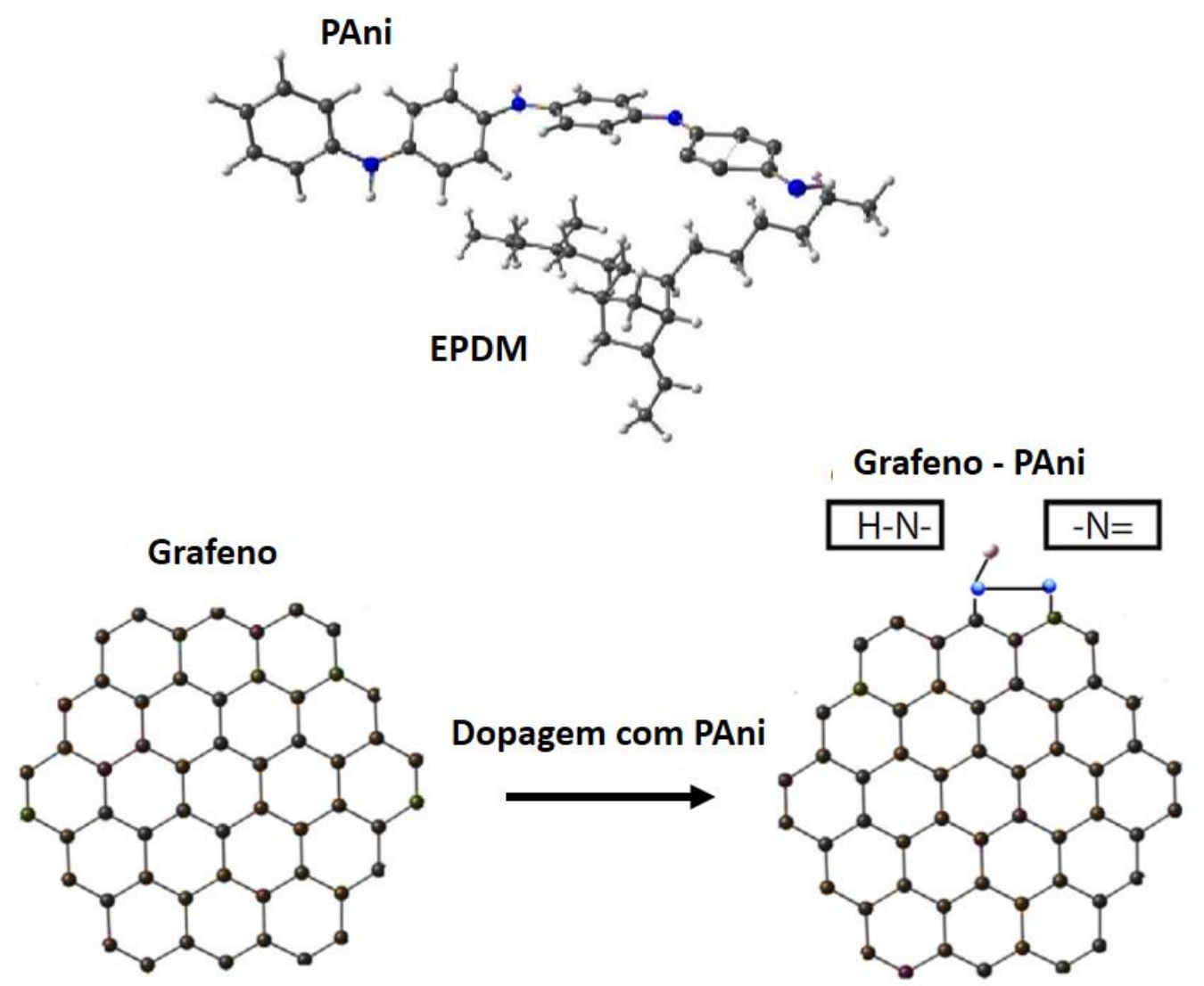

Figura 64: Estruturas químicas do EPDM-PAni, do grafeno e representação do mecanismo de dopagem.

\subsection{5}

Fabricação e caracterização dos dispositivos fotovoltaicos orgânicos à base de grafeno e grafeno/EPDM-PAni

Após a caracterização dos eletrodos de grafeno e de EPDM-PAni e, principalmente, da compreensão dos efeitos da blenda na estrutura do mesmo, começamos a fabricação dos dispositivos fotovoltaicos orgânicos utilizando os substratos à base de grafeno.

$\mathrm{Na}$ Figura 65 são mostradas as curvas características $\mathrm{J} \times \mathrm{V}$ dos dispositivos fotovoltaicos orgânicos fabricados com estrutura:

Substrato/eletrodo/CuPc (30)/ $\mathrm{C}_{60}(60) / \mathrm{Alq}_{3}$ (10)/ Ca (25)/ Al (75)

onde as espessuras, entre parênteses, são expressas em nanômetros, nas condições de no escuro e sob iluminação, utilizando os seguintes substratos/eletrodos:

- Vidro/ITO;

- Vidro/Grafeno;

- Vidro/Grafeno/EPDM-PAni. 

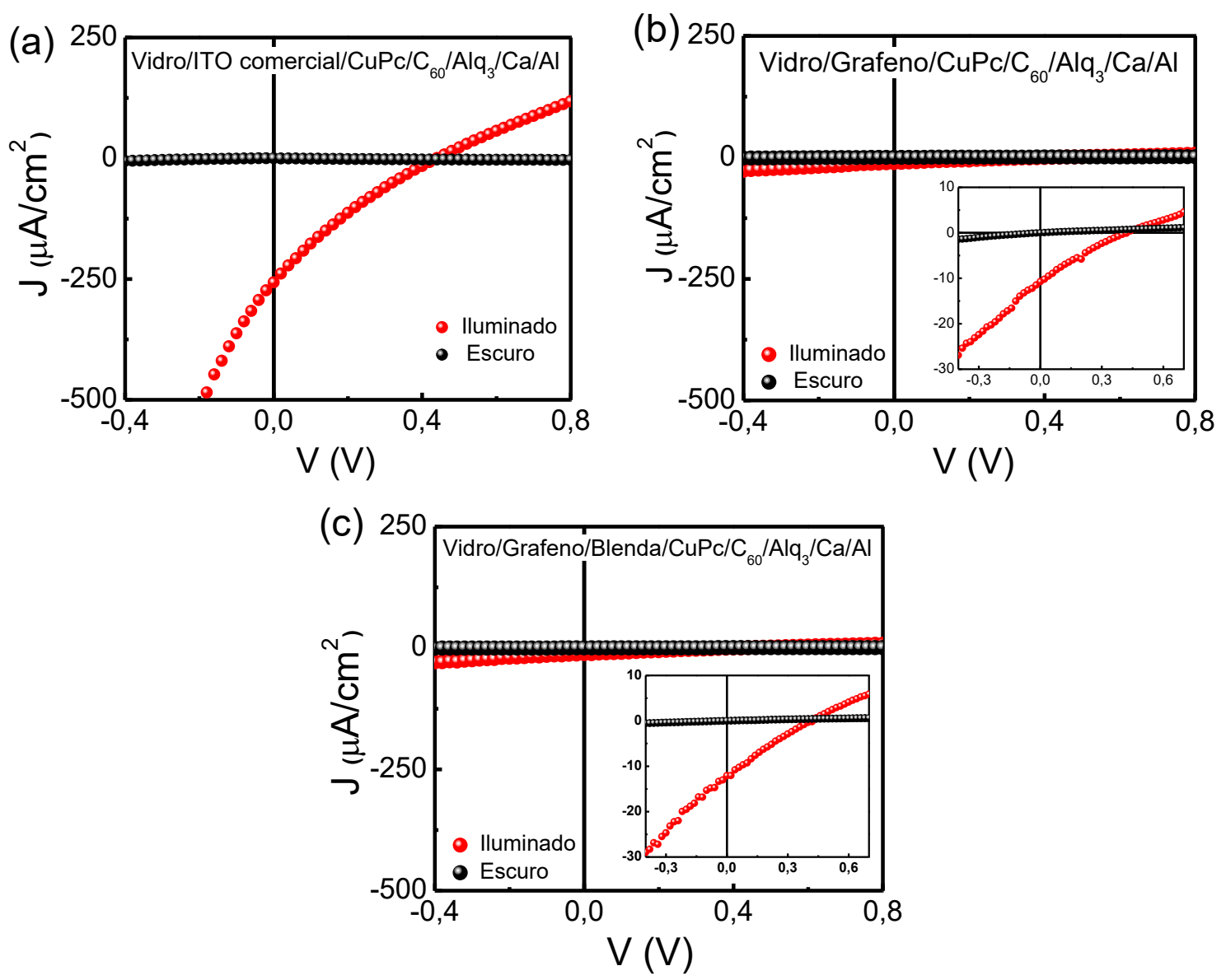

Figura 65: Densidade de corrente versus tensão $(\mathrm{J} \times \mathrm{V})$ dos Dispositivos fotovoltaicos orgânicos com estruturas tipo vidro/eletrodo/ $/ \mathrm{CuPc} / \mathrm{C}_{60} / \mathrm{Alq}_{3} / \mathrm{Ca} / \mathrm{Al}$, com e sem iluminação, utilizando os seguintes eletrodos: (a) ITO comercial, (b) grafeno e (c) grafeno/EPDM-PAni (blenda).

Observa-se nos resultados obtidos que para os dispositivos de grafeno e de grafeno/EPDM-PAni [Figura 65 (b) e (c)] não houve significativos aumentos da densidade de corrente para os mesmos valores de tensão aplicada, em relação ao dispositivo com ITO comercial. Este tipo de comportamento elétrico é típico de dispositivos fotovoltaicos orgânicos com baixa retificação [103], que pode ser causado por distintos fenômenos, como por exemplo, a recombinação dos portadores de carga [104] e/ou linhas de fuga de corrente (resistência paralela baixa) [105].

$\mathrm{Na}$ Tabela 6 são apresentados os valores dos parâmetros típicos dos dispositivos fotovoltaicos orgânicos fabricados com eletrodos de ITO, grafeno e grafeno/EPDMPAni, extraídos das curvas característica $\mathrm{J} \times \mathrm{V}$ mostradas na Figura 65 .

Observa-se que a diferença encontrada entre os valores de densidade de corrente de curto-circuito $\left(\mathrm{J}_{\mathrm{SC}}\right)$ dos distintos dispositivos é coerente com a diferença na resistência de folha entre os eletrodos. 
Tabela 6: Sumário com os principais parâmetros obtidos das curvas $\mathrm{J} \times \mathrm{V}$ dos dispositivos com estrutura Substrato/eletrodo/CuPc/ $\mathrm{C}_{60} / \mathrm{Alq}_{3} / \mathrm{Ca} / \mathrm{Al}$, mostradas na Figura 65 e o respectivo valor de resistência de folha $\left(R_{S}\right)$

\begin{tabular}{ccccc}
\hline Substrato/eletrodo & Voc $(\mathbf{V})$ & $\mathbf{J S C}_{\mathbf{S C}}\left(\mathbf{m A} / \mathbf{c m}^{\mathbf{2}}\right)$ & $\mathbf{F F}(\boldsymbol{\%})$ & PCE $(\%)$ \\
\hline Vidro/ITO (comercial) & 0.42 & 0,238 & 28 & 0,020 \\
Vidro/grafeno & 0,42 & 0,011 & 25 & 0,001 \\
Vidro/Grafeno/EPDM-PAni & 0,42 & 0,013 & 25 & 0,001 \\
\hline
\end{tabular}

A morfologia dos eletrodos tem uma forte influência sobre o valor da tensão de circuito aberto $\left(\mathrm{V}_{\mathrm{OC}}\right)$, principalmente devido a sua rugosidade. Como todos os valores de VoC são semelhantes para todos os dispositivos, é razoável concluir que a rugosidade dos eletrodos com grafeno tem pouca influência sobre a $V_{\text {OC. }}$

Ainda conforme a tabela acima, observa-se que os altíssimos valores de resistência de folha $\left(\mathrm{R}_{\mathrm{S}}\right)$ dos eletrodos de grafeno e de grafeno/EPDM-PAni, em relação ao ITO comercial, afeta diretamente o comportamento de $\mathrm{J}_{\mathrm{SC}} \mathrm{e}$, consequentemente, o fator de preenchimento $(\mathrm{FF})$. Em conjunto, estes valores resultam em uma diminuição significativa na eficiência de conversão de potência (PCE) dos dispositivos.

Importante destacar que o baixo valor da PCE do dispositivo fotovoltaico orgânico à base de ITO tem forte dependência com as espessuras das camadas orgânicas, as quais não foram otimizadas neste trabalho.

Por fim, ressalto que o objetivo inicial deste trabalho de doutoramento foi motivado pela utilização de grafeno como eletrodo condutor transparente depositado sobre substratos poliméricos flexíveis para ser aplicados em dispositivos fotovoltaicos orgânicos. Porém, a produção de grafeno teve que ser interrompida, devido a problemas técnicos no sistema de deposição e, por isso, como alternativa para continuidade do tema abordado, decidimos utilizar filmes finos de ITO depositado sobre os substratos poliméricos flexíveis investigados, conforme serão apresentados a seguir.

\section{2 \\ Caracterização e fabricação de dispositivos fotovoltaicos orgânicos com os substratos poliméricos flexíveis funcionalizados}

Neste doutoramento parte do trabalho foi dedicado ao desenvolvimento e otimização de substratos flexíveis que possam ser aplicados aos dispositivos fotovoltaicos orgânicos. Além de flexíveis e transparentes este precisam ser condutores. Para isso, 
depositamos um filme fino de óxido de índio e estanho (ITO) sobre uma das superfícies do substrato polimérico. Neste momento descreverei os resultados e experimentos pertinentes à deposição de ITO. No próximo item deste capítulo será apresentado os resultados da aplicabilidade destes substratos em dispositivos fotovoltaicos orgânicos.

\subsection{1 \\ Otimização e deposição de ITO sobre vidro}

Antes de começarmos as deposições de ITO sobre os substratos poliméricos flexíveis, tais como PVA, PVC e BC, testamos os procedimentos em substratos de vidro, pelo fato deste ser um material comumente descrito na literatura, servindo-o como referência para nossos experimentos.

Para otimizar as condições de deposição, filmes finos de ITO foram depositados sobre substratos de vidro, variando a pressão de trabalho e a potência da fonte de deposição. Esta parametrização permitiu maximizar a qualidade das deposições finais, tanto sobre vidro, quanto sobre os substratos flexíveis. As propriedades elétricas dos substratos foram investigadas após os processos de deposição, principalmente através da análise de resistência de folha dos substratos.

Importante destacar neste momento que os valores sugeridos e avaliados para determinar as melhores condições de deposição têm origem em trabalhos anteriores do nosso grupo de pesquisa [63]. Contudo, sempre é recomendado reavaliar as condições previamente otimizada, devido às peculiaridades do sistema de deposição utilizado. Isso porque o sistema passa por constantes intervenções de manutenção e calibrações, bem como variações intrínsecas dos materiais percussores utilizados.

\section{$\underline{\text { Variação da pressão de trabalho }}$}

Inicialmente manteve-se a potência da fonte e o tempo de deposição fixos, variando apenas a pressão de trabalho do sistema de 2 a 3 mTorr. A Tabela 8 resume os parâmetros utilizados para a deposição dos filmes de ITO sobre vidro e seus respectivos valores de resistências de folha.

Observa-se da Tabela 7 que o valor da resistência de folha diminuiu quando aumentamos a pressão de trabalho do sistema de 2 para 3 mTorr. Os valores de espessura apresentados foram obtidos experimentalmente através da técnica de perfilometria. 
Tabela 7: Parâmetros utilizados para a deposição dos filmes de ITO sobre vidro e seus respectivos valores de resistências de folha.

\begin{tabular}{ccccccc}
\hline Substrato & $\begin{array}{c}\text { Potência } \\
(\mathbf{w})\end{array}$ & $\begin{array}{c}\text { Pressão de } \\
\text { Trabalho } \\
(\mathbf{m T o r r})\end{array}$ & $\begin{array}{c}\text { Tempo } \\
(\mathbf{s})\end{array}$ & $\begin{array}{c}\text { Espessura } \\
(\mathbf{n m})\end{array}$ & $\begin{array}{c}\text { Taxa de } \\
\text { deposição } \\
(\mathbf{n m} / \mathbf{s})\end{array}$ & $\begin{array}{c}\text { Resistência } \\
\text { de folha } \\
(\mathbf{\Omega})\end{array}$ \\
\hline Vidro & 80 & 2,0 & 1800 & $273,3 \pm 8,0$ & 0,149 & $17,0 \pm 0,8$ \\
Vidro & 80 & 3,0 & 1800 & $273,3 \pm 1,1$ & 0,149 & $13,8 \pm 0,7$ \\
\hline
\end{tabular}

\section{Variação da potência da fonte}

Após observarmos que a menor resistência de folha obtida da deposição de ITO sobre vidro ocorreu com uma pressão de trabalho de 3 mTorr, fixou-se a pressão de trabalho neste valor e passamos a variar a potência da fonte de deposição de 70 a $90 \mathrm{~W}$, como mostra a Tabela 8.

Tabela 8: Parâmetros utilizados para a deposição dos filmes de ITO sobre vidro e seus respectivos valores de resistências de folha.

\begin{tabular}{ccccccc} 
Substrato & $\begin{array}{c}\text { Potência } \\
(\mathbf{w})\end{array}$ & $\begin{array}{c}\text { Pressão de } \\
\text { trabalho } \\
(\mathbf{m T o r r})\end{array}$ & $\begin{array}{c}\text { Tempo } \\
(\mathbf{s})\end{array}$ & $\begin{array}{c}\text { Espessura } \\
(\mathbf{n m})\end{array}$ & $\begin{array}{c}\text { Taxa } \\
(\mathbf{n m} / \mathbf{s})\end{array}$ & $\begin{array}{c}\text { Resistência } \\
\text { de folha } \\
\mathbf{( \Omega / s q})\end{array}$ \\
\hline Vidro & 70 & 3,0 & 1800 & $255,1 \pm 2,4$ & 0,139 & $19,6 \pm 0,8$ \\
Vidro & 80 & 3,0 & 1800 & $273,3 \pm 1,1$ & 0,149 & $13,8 \pm 0,7$ \\
Vidro & 90 & 3,0 & 1800 & $337,9 \pm 2,2$ & 0,185 & $26,2 \pm 1,5$ \\
\hline
\end{tabular}

Nota-se da tabela acima que a taxa de deposição de ITO sobre vidro aumenta proporcionalmente com a potência aplicada à deposição, produzindo filmes de ITO cada vez mais espessos. Contudo, ao analisar o valor da resistência de folha em relação à potência de deposição aplicada, observa-se que o menor valor medido foi obtido com uma deposição feita à 80 W. Dessa forma, uma menor potência de deposição e, consequentemente, uma menor taxa de deposição, não representa necessariamente a melhor condição de fabricação do substrato, a fim de obter o menor valor possível de resistência de folha.

Após a variação dos principais parâmetros que influenciam a deposição de ITO, consideramos que a melhor condição foi a mostrada na Tabela 9. Para a fabricação dos 
dispositivos fotovoltaicos orgânicos escolhemos uma espessura para os filmes de ITO na ordem de $270 \mathrm{~nm}$.

Tabela 9: Parâmetros com a melhor condição de deposição dos filmes de ITO sobre vidro.

\begin{tabular}{ccccc} 
Substrato & $\begin{array}{c}\text { Potência } \\
(\mathbf{W})\end{array}$ & $\begin{array}{c}\text { Pressão de trabalho } \\
(\mathbf{m} \text { Torr })\end{array}$ & $\begin{array}{c}\text { Tempo } \\
(\mathbf{s})\end{array}$ & $\begin{array}{c}\text { Taxa } \\
(\mathbf{n m} / \mathbf{s})\end{array}$ \\
\hline Vidro & 80 & 3,0 & 1800 & 0,15 \\
\hline
\end{tabular}

\subsection{2}

\section{Caracterização dos substratos flexíveis}

Após a prévia deposição e caracterização do ITO sobre substrato de vidro, o qual é o nosso substrato de referência, passamos a avaliar os parâmetros necessários para depositar o mesmo material sobre os três tipos de substratos poliméricos investigados nesta tese, a saber: PVA (espessura de 47,3 $\pm 0,8 \mu \mathrm{m}$ ), PVC (espessura de 45,6 $\pm 1,5 \mu \mathrm{m}$ ), e BC modificada com PVC (espessura entre 14 e $68 \mu \mathrm{m}$ ).

Neste trabalho decidiu-se não utilizar a BC pura para a fabricação dos eletrodos transparente, visto que a BC modificada (simplesmente chamada de BC) possui transmitância ótica muito superior à pura, como pode ser observado na Figura 66. Observa-se neste gráfico, que a transmitância ótica da BC é aproximadamente $80 \%$ em $550 \mathrm{~nm}$, sendo este valor pouco abaixo ao do vidro utilizado como referência (90\%).

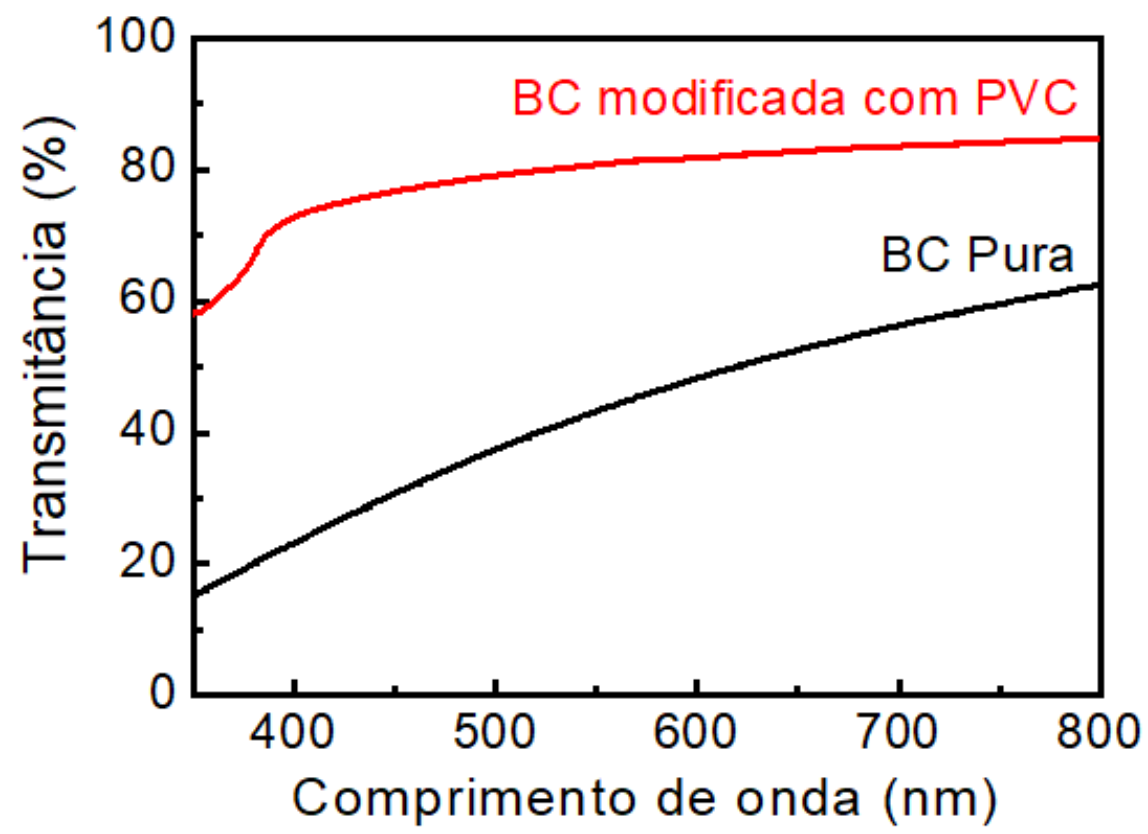

Figura 66: Medidas de UV-Vis dos substratos de BC e da BC modificada com PVC. 
Outro ponto importante a ser observado é o fato de termos utilizado PVC comercial, utilizado comumente em plastificação. Por esse motivo, para garantir que estava utilizando realmente PVC e não outro material qualquer, resolvi analisá-lo através da técnica de FTIR. A Figura 67, a seguir, mostra os modos de excitação do polímero analisado, confirmando que realmente estou utilizando PVC, mesmo que este contenha alguns modos não característicos, sugerindo modificações em sua estrutura ou até mesmo a inclusão de impurezas.

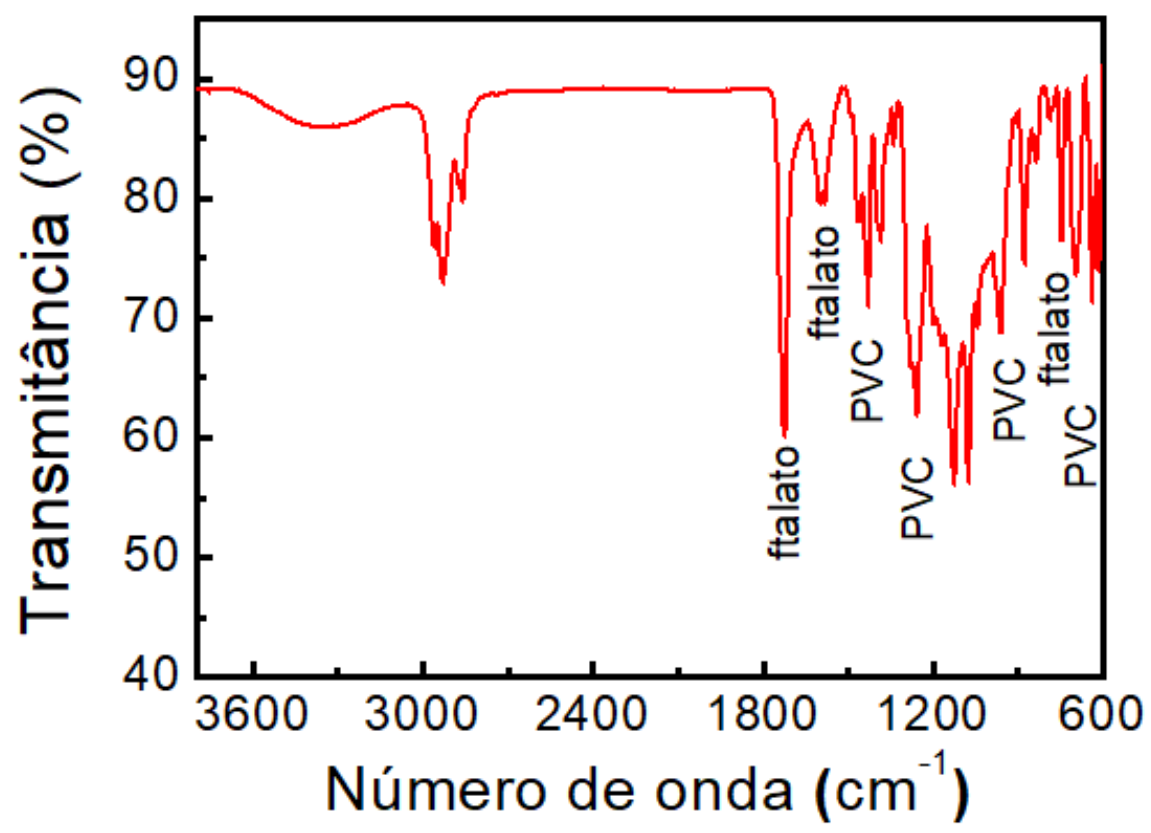

Figura 67: Medida de FTIR da matéria prima utilizada para fabricar os substratos de PVC.

Os modos vibracionais observados além dos modos característicos do PVC indicam a presença de ésteres de ftalatos, os quais são comumente usados como plastificantes, fazendo jus ao tipo de material adquirido comercialmente.

\subsection{3}

\section{Deposição de ITO sobre os substratos poliméricos}

Até o momento, o valor de resistência de folha tem sido utilizado como o único parâmetro para determinar qual a melhor condição de deposição de ITO, com espessura na ordem de $270 \mathrm{~nm}$, o qual ocorreu com pressão de trabalho de 3,0 mTorr à $80 \mathrm{~W}$.

Todavia, a transmitância ótica é uma propriedade fundamental a ser investigada, visto que o eletrodo do dispositivo fotovoltaico orgânico deve permitir ao máximo 
possível a passagem de luz até a camada ativa do dispositivo, para que ocorra a formação dos éxcitons.

Nesse sentido, a Figura 68 mostra a transmitância ótica em relação ao comprimento de onda para os diferentes substratos poliméricos investigados, com e sem ITO depositado, bem como para o vidro, o qual é utilizado como referência.

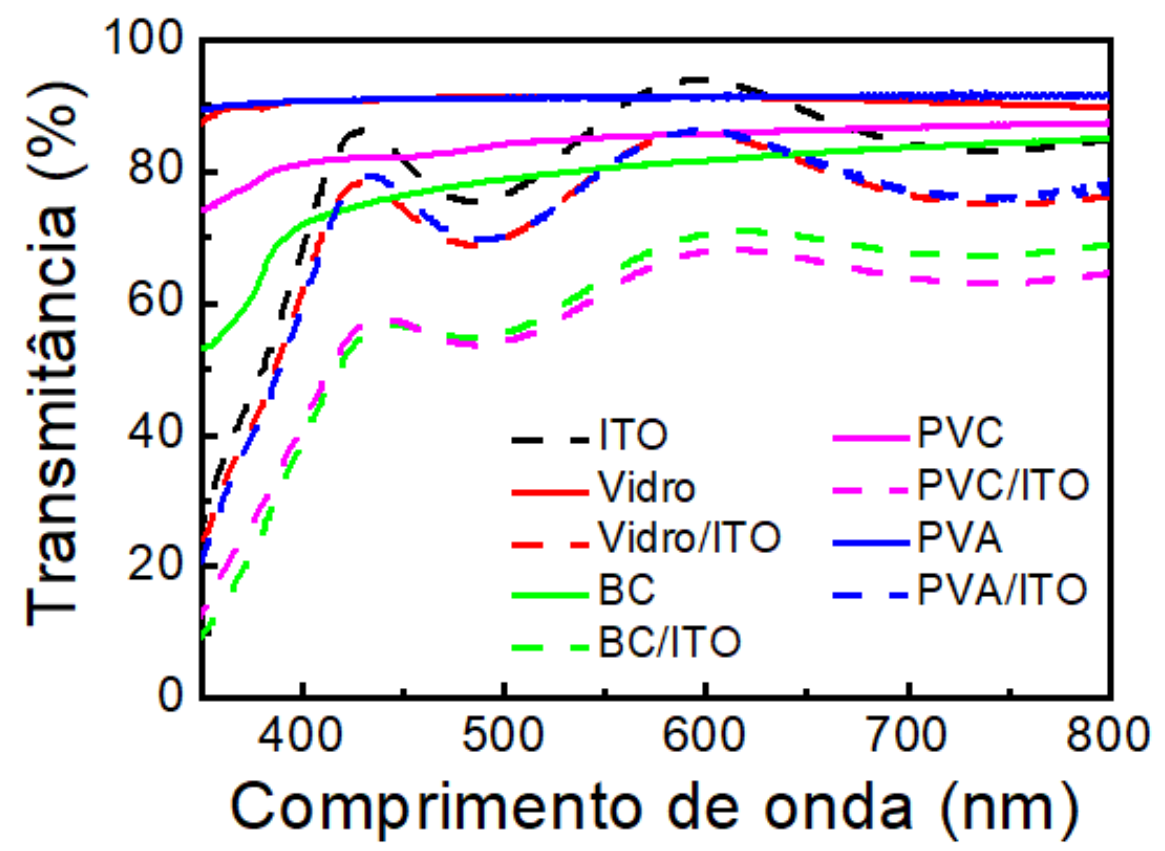

Figura 68: Medidas de UV-Vis dos substratos de vidro, BC, PVC e PVA, e das mesmas com deposição de filme fino de ITO.

Observa-se a partir desse gráfico que o vidro e o PVA têm espectros muito similares, ao passo que o PVC e a BC possuem uma atenuação significativa do espectro para todo comprimento de onda explorado. O comportamento do espectro do vidro e do PVA são semelhantes aos demais substratos, quando a camada de ITO é depositada sobre eles. Nota-se que mesmo após a deposição de ITO, os eletrodos sobre vidro e PVA também apresentam comportamentos semelhantes, enquanto as transmitâncias dos eletrodos sobre PVC e BC também foram atenuadas, em concordância com os substratos não submetidos à deposição de ITO.

Por fim, a Tabela 10 correlaciona os valores obtidos para a resistência de folha e para a transmitância ótica em $550 \mathrm{~nm}$ para os distintos substratos com ITO depositado. Nesta mesma tabela são apresentadas as variações percentuais $(\Delta \%)$ para cada propriedade investigada, em relação ao substrato de vidro/ITO utilizado como referência no nosso trabalho. 
Tabela 10: Valores de resistência de folha e de transmitância ótica em $550 \mathrm{~nm}$ para os distintos substratos estudados com ITO depositado e a variação percentual da propriedade em relação ao substrato de vidro/ITO.

\begin{tabular}{ccccc} 
Substrato & $\begin{array}{c}\text { Resistência de } \\
\text { folha }(\mathbf{R s})\end{array}$ & $\begin{array}{c}\Delta \text { Rs em } \\
\text { relação ao } \\
\left(\mathbf{\Omega} \mathbf{s q}^{-\mathbf{1}}\right)\end{array}$ & $\begin{array}{c}\text { Transmitância }(\mathbf{T}) \\
\text { vidro }(\boldsymbol{\%})\end{array}$ & $\begin{array}{c}\Delta \text { T em } \\
\text { relação ao }\end{array}$ \\
\hline Vidro/ITO & $13,3 \pm 0,6$ & - & 80,7 & vidro $(\%)$ \\
PVA/ITO & $14,0 \pm 0,7$ & 5,3 & 80,3 & - \\
BC/ITO & $14,9 \pm 0,7$ & 12,0 & 63,9 & $-0,5$ \\
PVC/ITO & $15,3 \pm 0,7$ & 15,0 & 61,8 & $-20,8$ \\
\hline
\end{tabular}

Observa-se que o substrato híbrido de PVC/ITO apresentou as maiores variações de suas propriedades (em valores percentuais absolutos) em relação ao vidro/ITO. Este apresentou um aumento de $15 \%$ na resistência de folha e uma diminuição de 23,4\% no valor de sua transmitância ótica. Dessa forma, cogita-se que o PVC/ITO possa apresentar os piores resultados de eficiência de conversão de potência dentre os substratos híbridos aplicados em dispositivos fotovoltaicos orgânicos. O mesmo segue para a BC, a qual apresentou aumento na resistência de folha em torno de $12 \%$ e uma diminuição de $21 \%$ em sua transmitância ótica.

Por outro lado, a resistência de folha do PVA/ITO aumentou apenas 5\% em relação ao Vidro/ITO, bem como apresenta praticamente a mesma transmitância ótica, em torno de $80 \%$ do vidro.

Portanto, constata-se que foi possível determinar uma condição experimental capaz de diminuir a resistência de folha do eletrodo e manter na mesma ordem a transmitância ótica, em relação ao nosso material de referência, o que indica a viabilidade de fabricar um dispositivo fotovoltaico orgânico feito com substrato flexível com valores próximos à eficiência de conversão de potência do dispositivo com vidro/ITO.

$\underline{\text { Estabilidade temporal da resistência de folha para diferentes eletrodos }}$

Para verificar a estabilidade temporal dos eletrodos e assim conseguirmos estimar seu tempo de degradação, realizamos uma série de medidas utilizando sempre as mesmas amostras e mantendo as mesmas condições experimentais, para determinar suas respectivas resistências de folha. 
Importante citar que nesta caracterização os substratos híbridos foram mantidos constantemente armazenados na glove box em ambiente inerte (nitrogênio) e expostos ao ambiente oxidante apenas durante um curto período de tempo, necessário apenas para realizar as medidas de resistência de folha que serão mostradas a seguir. Após as medições, os eletrodos foram novamente armazenados em glove box. Este procedimento foi mantido para todos os dias indicados da Figura 69.

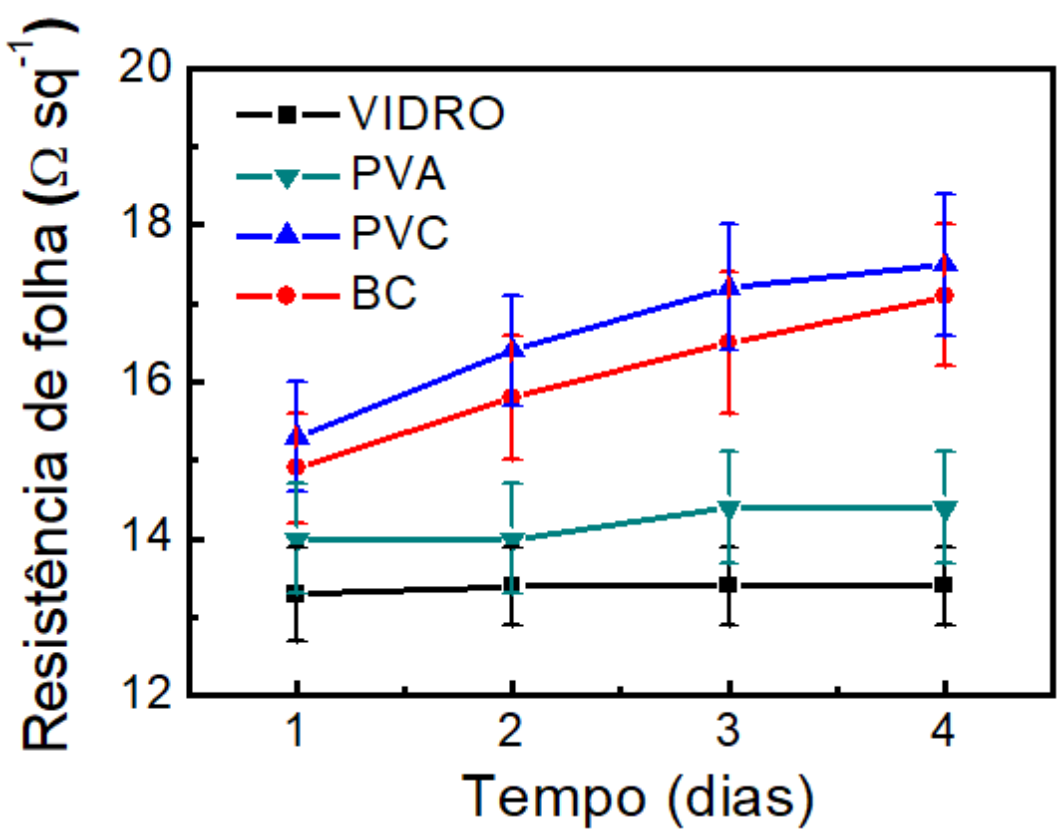

Figura 69: Evolução temporal do comportamento da resistência de folha dos filmes finos de ITO depositado sobre os substratos de vidro, PVA, PVC e BC.

Observa-se na Figura 69 que o comportamento da resistência de folha do ITO sobre o PVA permaneceu praticamente constante e linear em relação ao vidro, principalmente pelo fato das barras de erro se sobreporem, ao passo que os demais eletrodos tiveram um aumento significativo e, consequentemente, prejudicial desta propriedade.

Outro ponto relevante a ser avaliado refere-se à estabilidade temporal dos eletrodos, quando estes permanecem constantemente expostos ao ambiente oxidante (pressão, temperatura e umidade ambiente).

Por este motivo, medimos a massa de diferentes eletrodos ao longo de 5 dias, mantendo as mesmas condições experimentais. Esta medição foi realizada com uma balança analítica (marca Mettler Toledo AB265-S com divisão de $10 \mu \mathrm{g}$ ), enquanto as amostras eram mantidas permanentemente na temperatura de $22 \pm 3^{\circ} \mathrm{C}$ e umidade de 70 $\pm 5 \%$. A Figura 70 mostra a evolução da massa destes eletrodos. 


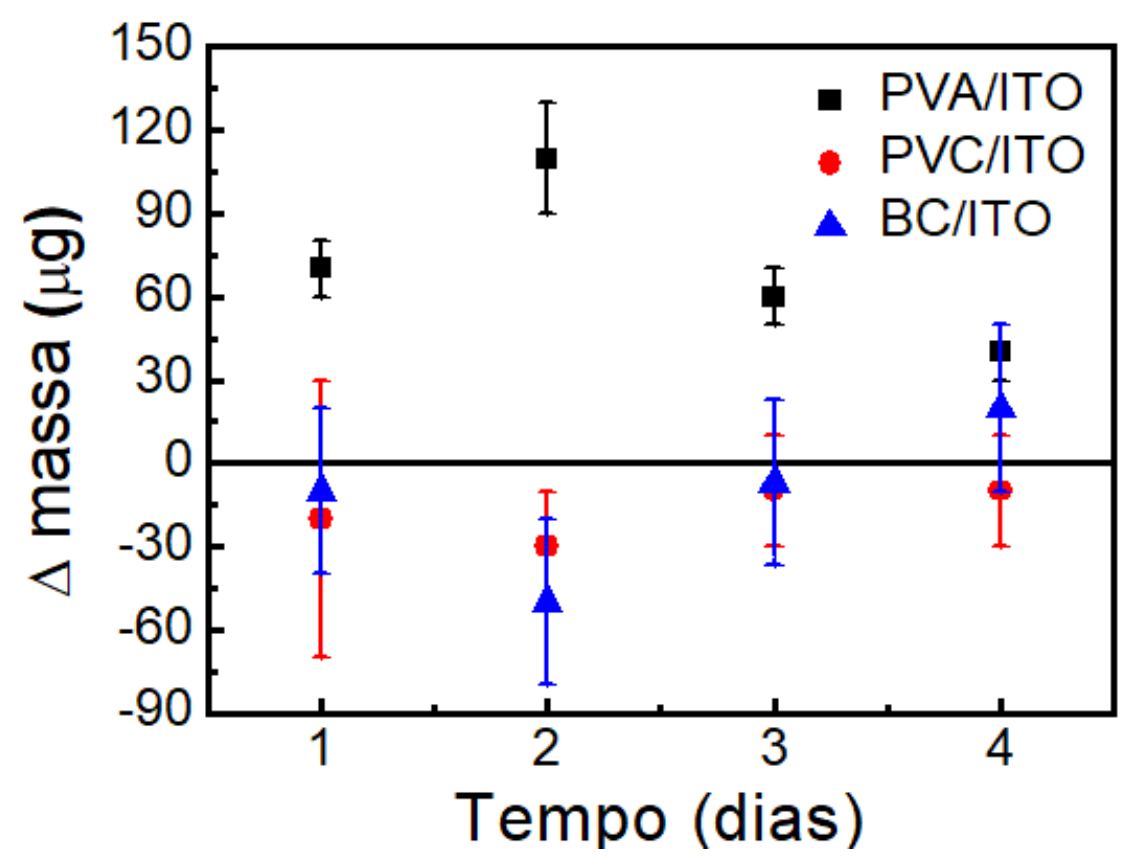

Figura 70: Variação da massa dos substratos poliméricos com ITO depositado em função do tempo. A barra de erro apresentada tem origem no desvio padrão obtido a partir da média das cinco medidas realizadas em cada ponto.

A partir da Figura 70 observa-se que o eletrodo que mais sofreu variação em sua massa foi o PVA/ITO, em torno de até $0,1 \mu \mathrm{g}$. Para os demais substratos não se observa variações significativas, dentro dos desvios padrões estimados.

À primeira vista estes resultados parecem ser contraditórios aos apresentados anteriormente na Figura 69. Mas estes diferem-se significantemente, em virtude da variação da massa de cada eletrodo ter sido avaliada perante exposição contínua do mesmo ambiente oxidante, no intuito de avaliar a degradação, principalmente devido à possível absorção de água, ao passo que a Figura 69 apresenta resultados com os eletrodos mantido em ambiente inerte. Os resultados apresentados na Figura 70 parecem ser coerentes, visto que o PVA é extremante solúvel a água, ao passo que o PVC e a BC apresentam baixa solubilidade ao ambiente aquoso. 


\subsection{4 Fabricação e caracterização dos dispositivos fotovoltaicos orgânicos com substratos poliméricos flexíveis}

Em virtude dos satisfatórios resultados apresentados previamente, tais como o sucesso na deposição de ITO sobre os substratos poliméricos, bem como os valores de resistência de folha e transmitância ótica na ordem do vidro/ITO, o qual é nossa referência, fabriquei e caracterizei diversas estruturas de dispositivos fotovoltaicos orgânicos de modo a comprovar a potencialidade do uso dos substratos poliméricos como substratos flexíveis e transparentes.

Investiguei o desempenho dos eletrodos de ITO sobre os substratos de PVA, PVC e BC, comparando com um análogo de vidro e também com o ITO comercial (Lumtec Corp.) submetido às mesmas condições de fabricação. Para cada substrato polimérico investigado fabriquei três diferentes estruturas, onde cada dispositivo possui área ativa de aproximadamente $3 \mathrm{~mm}^{2}$, como serão descritas a seguir.

\section{Dispositivo com heterojunção em bicamada $\left(\mathrm{CuPc} / \mathrm{C}_{60}\right)$}

Esta primeira estrutura investigada é similar à fabricada utilizando o grafeno como eletrodo, a saber:

\section{Substrato/ITO/CuPc (25)/ C60 (40)/ $\mathrm{Alq}_{3}(10) / \mathrm{Ca}(25) / \mathrm{Al}(100)$}

onde as espessuras, em parênteses, são expressas em nanômetros.

As curvas características de $\mathrm{J} \times \mathrm{V}$ dos dispositivos fotovoltaicos orgânicos fabricados com os substratos de vidro com ITO comercial e, vidro e substratos poliméricos de PVA, PVC e BC com ITO depositado, no escuro e sob iluminação, são mostradas nos gráficos da Figura 71. Os valores dos parâmetros típicos usados na caracterização dos dispositivos fotovoltaicos orgânicos, os quais foram extraídos a partir das curvas características de $\mathrm{J} \times \mathrm{V}$, são mostrados na Tabela 11 .

Observa-se que o dispositivo com o substrato híbrido comercial de vidro/ITO apresentou uma tensão de circuito aberto $\left(\mathrm{V}_{\mathrm{OC}}\right)$ maior e um fator de preenchimento $(\mathrm{FF})$ menor em comparação aos demais, os quais apresentaram valores de Vocs e FF semelhantes. 
(a)

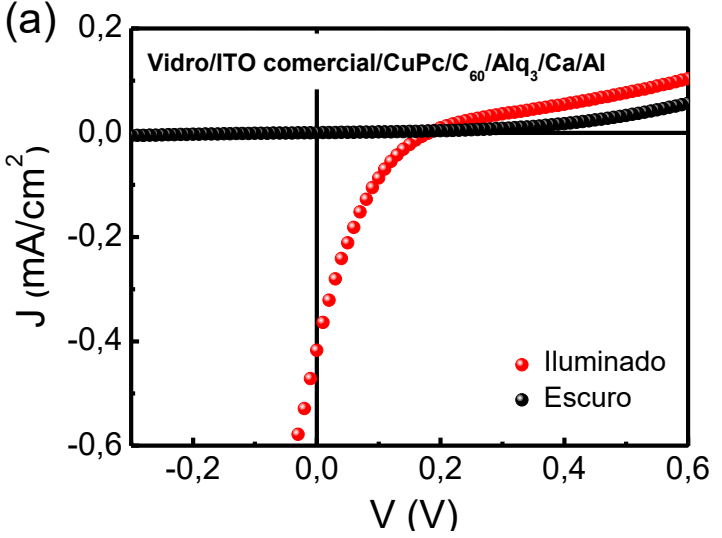

(c) 0,2

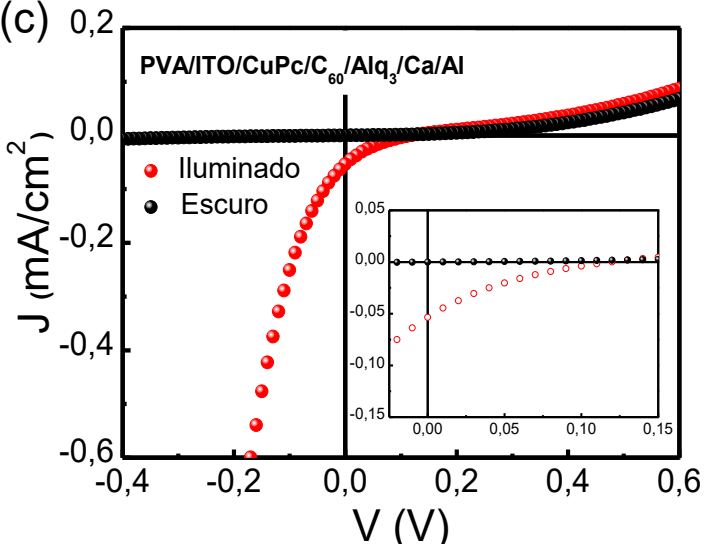

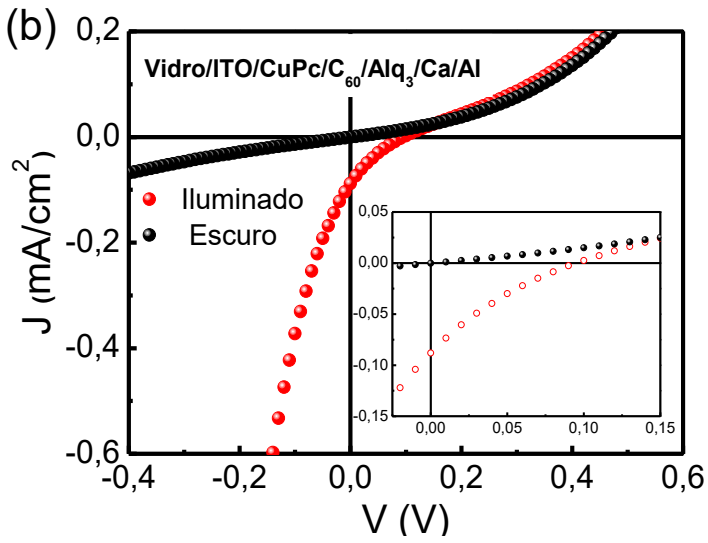

(d)

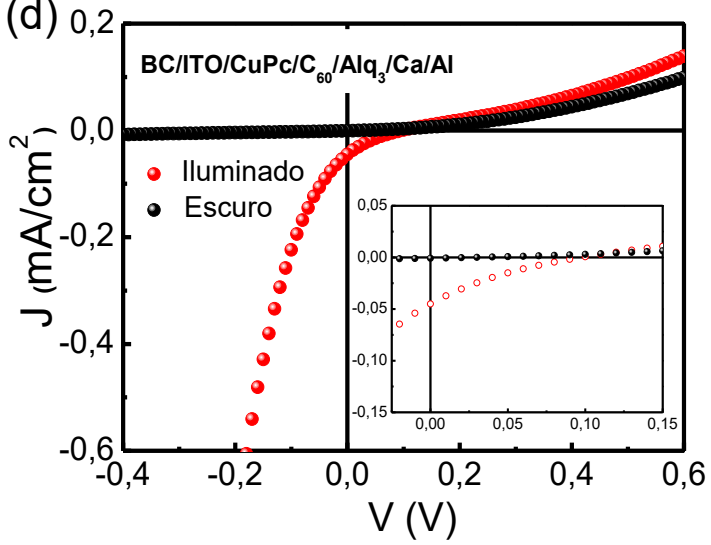

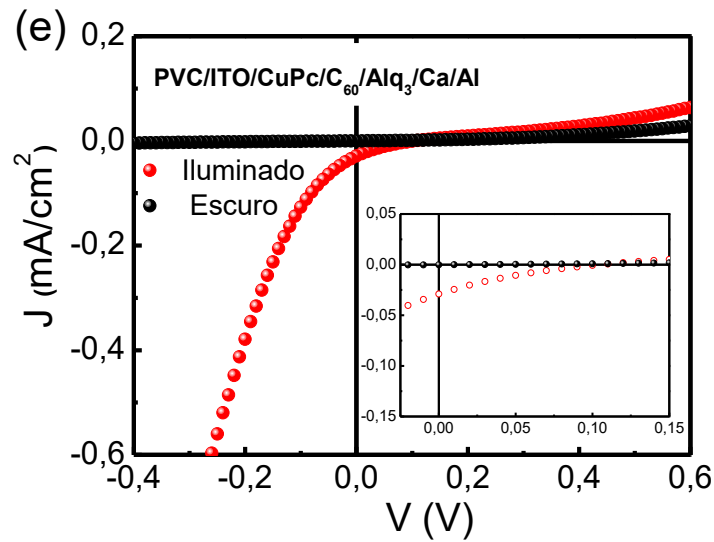

Figura 71: Curvas características de densidade de corrente versus tensão aplicada $(\mathrm{J} \times \mathrm{V})$ aos dispositivos com estrutura tipo substrato/eletrodo/ $\mathrm{CuPc} / \mathrm{C}_{60} / \mathrm{Alq}_{3} / \mathrm{Ca} / \mathrm{Al}$ com os seguintes substratos/eletrodo: (a) Vidro/ITO (comercial); (b) Vidro/ITO; (c) PVA/ITO; (d) BC/ITO; (e) PVC/ITO.

Em geral, os dispositivos apresentaram uma baixa eficiência pelo fato das camadas orgânicas não serem otimizadas, mas foram semelhantes aos valores de eficiência de conversão de potência (PCE) encontrados nos dispositivos com eletrodos de grafeno. Entre os fatores que podem ter prejudicado o desempenho desses dispositivos destaco: a espessura não adequada dos materiais orgânicos, a utilização de duas camadas 
modificadoras de interface ( $\mathrm{Alq}_{3}$ e $\mathrm{Ca}$ ), além da possível oxidação do Ca prejudicando a transporte de elétrons até o eletrodo de $\mathrm{Al}$, entre outros.

Todavia, estes mesmos resultados comprovam que tais substratos poliméricos podem ser utilizados como substratos flexíveis e transparentes em dispositivos fotovoltaicos orgânicos, necessitando apenas de uma melhor otimização das camadas orgânicas dos dispositivos.

Tabela 11: Sumário com os principais parâmetros obtidos a partir das curvas $\mathrm{J} \times \mathrm{V}$ dos dispositivos com estrutura substrato/eletrodo/CuPc/ $\mathrm{C}_{60} / \mathrm{Alq}_{3} / \mathrm{Ca} / \mathrm{Al}$, mostradas na Figura 71.

\begin{tabular}{ccccc} 
Substrato/Eletrodo & Voc $(\mathbf{V})$ & Jsc $\left(\mathbf{m A} / \mathbf{c m}^{2}\right)$ & FF (\%) & PCE (\%) \\
\hline Vidro/ITO (comercial) & 0,16 & 0,44 & 22 & 0,0100 \\
Vidro/ITO & 0,11 & 0,09 & 22 & 0,0020 \\
PVA/ITO & 0,12 & 0,05 & 22 & 0,0013 \\
BC/ITO & 0,11 & 0,04 & 22 & 0,0010 \\
PVC/ITO & 0,11 & 0,03 & 22 & 0,0007 \\
\hline
\end{tabular}

\section{Dispositivo com heterojunção em volume (CuPc:C60)}

Com objetivo de otimizar o dispositivo e, consequentemente, aumentar a sua eficiência, acrescentei na sua estrutura uma camada de um material injetor de buracos, o $\mathrm{MoO}_{3}$. Nessa otimização, também substituí o $\mathrm{Alq}_{3}$ pelo TPBI, o qual atua como uma camada transportadora de elétrons mais eficiente. A camada ativa do dispositivo, no qual a luz interage e ocorre a formação e a dissociação do éxciton, é substituída por uma heterojunção em volume de $\mathrm{CuPc}$ e $\mathrm{C}_{60}\left(\mathrm{CuPc}_{\mathrm{C}} \mathrm{C}_{60}\right)$, ao invés de depositar esses dois materiais em camadas, formando uma bicamada. A camada de Ca não foi mantida, e apenas foi depositado o $\mathrm{Al}$ como eletrodo metálico.

Com essas alterações, os dispositivos foram fabricados de acordo com a seguinte estrutura:

$$
\text { Substrato/ITO/ } \mathrm{MoO}_{3} \text { (5)/ CuPc (25):C6o (40)/ TPBI (10)/ Al (100) }
$$

onde as espessuras, em parênteses, são expressas em nanômetros. 
As curvas características de $\mathrm{J} \times \mathrm{V}$ dos dispositivos fotovoltaicos orgânicos fabricados com os substratos de vidro com ITO comercial e, vidro e substratos de PVA, PVC e BC com ITO depositado, no escuro e sob iluminação, são mostradas nos gráficos da Figura 72.
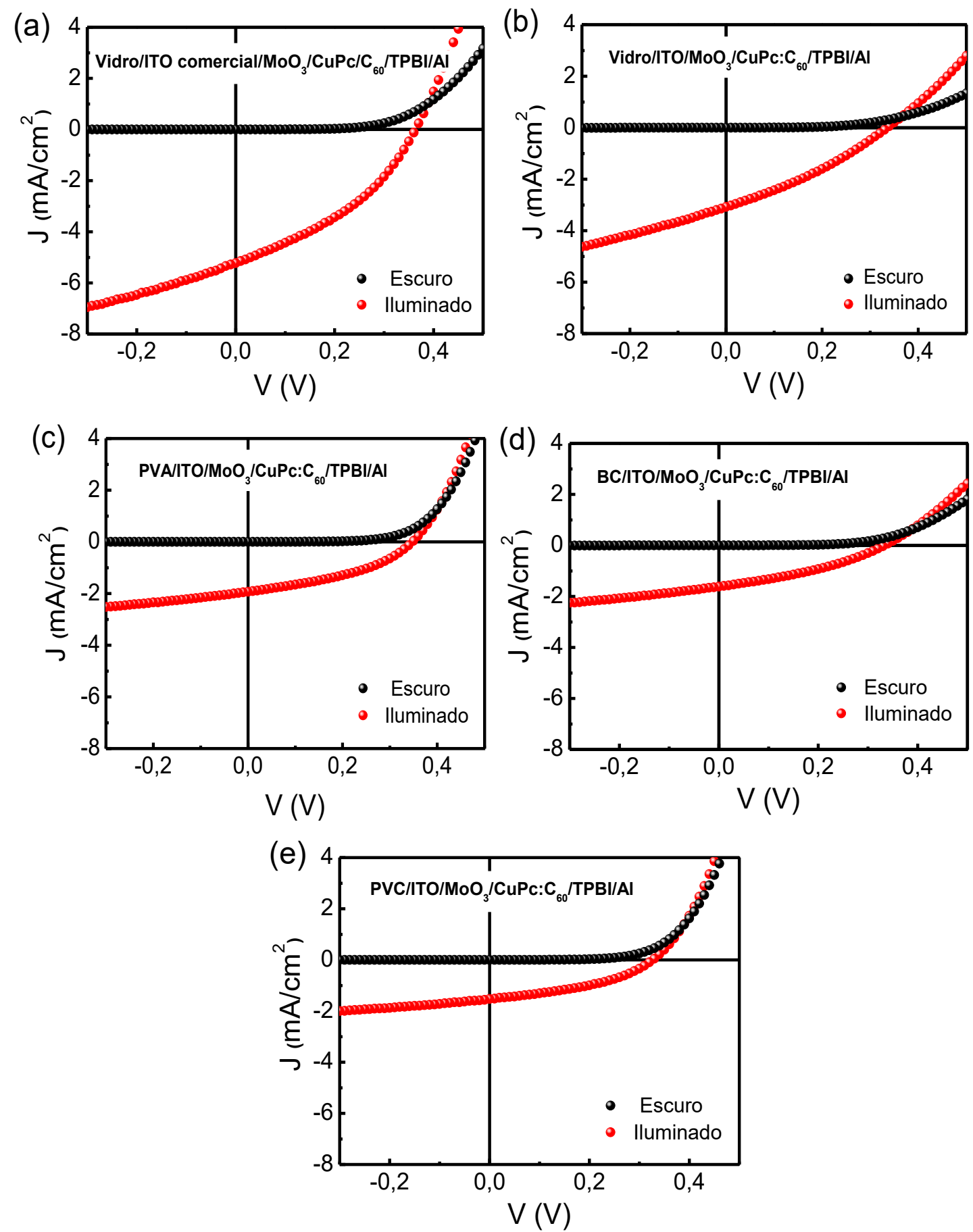

Figura 72: Curvas características de densidade de corrente versus tensão aplicada $(\mathrm{J} \times \mathrm{V})$ aos dispositivos com estrutura tipo substrato/eletrodo/ $\mathrm{MoO}_{3} / \mathrm{CuPc}: \mathrm{C}_{60} / \mathrm{TPBI} / \mathrm{Al}$, com os seguintes substratos/eletrodo: (a) Vidro/ITO (comercial); (b) Vidro/ITO; (c) PVA/ITO; (d) BC/ITO; (e) PVC//ITO. 
Os valores dos parâmetros típicos usados na caracterização dos dispositivos fotovoltaicos orgânicos, os quais foram extraídos a partir das curvas características $\mathrm{J} \times \mathrm{V}$, são mostrados na Tabela 12.

Tabela 12: Sumário com os principais parâmetros obtidos a partir das curvas $\mathrm{J} \times \mathrm{V}$ dos dispositivos com estrutura substrato/eletrodo/ $\mathrm{MoO}_{3} / \mathrm{CuPc}: \mathrm{C}_{60} / \mathrm{TPBI} / \mathrm{Al}$, mostradas na Figura 72.

\begin{tabular}{ccccc} 
Substrato/Eletrodo & Voc $(\mathbf{V})$ & $\mathbf{J s c}\left(\mathbf{m A} / \mathbf{c m}^{2}\right)$ & FF (\%) & PCE (\%) \\
\hline Vidro/ITO (comercial) & 0,37 & 5,2 & 37 & 0,71 \\
Vidro/ITO & 0,34 & 3,2 & 31 & 0,33 \\
PVA/ITO & 0,34 & 2,0 & 33 & 0,24 \\
BC/ITO & 0,34 & 1,7 & 31 & 0,18 \\
PVC/ITO & 0,33 & 1,5 & 31 & 0,15 \\
\hline
\end{tabular}

De forma geral, observei um aumento considerável tanto da $\mathrm{J}_{\mathrm{SC}}$, quanto da $\mathrm{V}_{\mathrm{OC}}$ para todos os dispositivos, em comparação aos anteriores, acarretando em FF e valores de PCE mais altos. Dessa forma, o aumento dos valores de PCE destes dispositivos fotovoltaicos orgânicos ocorreu devido às modificação e substituições das camadas presentes nesta estrutura, empregado como forma de otimização do dispositivo.

Por fim, os valores da $\mathrm{J}_{\mathrm{SC}}$ são proporcionais aos valores de resistência de folha dos dispositivos, onde o substrato híbrido comercial de vidro/ITO apresentou o maior valor, seguido do substrato híbrido de vidro/ITO fabricado. As VOCS e os FFs dos dispositivos foram semelhantes entre si, ao passo que o dispositivo com substrato híbrido comercial de vidro/ITO apresentou valores superiores.

Novamente, o dispositivo com o substrato híbrido comercial de vidro/ITO foi o que apresentou a melhor PCE, chegando a um valor de $0,7 \%$. Dentre os substratos híbridos fabricados, o dispositivo com vidro/ITO foi o que apresentou a maior PCE, seguido dos substratos de PVA, BC e PVC com ITO depositado. Acredita-se que este resultado favorável ao material cristalino se deve a facilidades quanto à molhabilidade, baixa rugosidade, entre outros fatores, os quais não foram avaliados em detalhes nesta tese. 
$\underline{\text { Dispositivo com heterojunção em bicamada }\left(\mathrm{CuPc} / \mathrm{C}_{60}\right)}$

Também fabriquei dispositivos semelhante à estrutura anterior, contudo não depositei a camada ativa com heterojunção em volume de $\mathrm{CuPc}$ e $\mathrm{C}_{60}$, e sim uma estrutura em bicamada destes mesmos materiais e com as mesmas espessuras. Portanto, a nova estrutura investigada foi:

Substrato/ITO/MoO 3 (5)/ CuPc (25)/ C60 (40)/ TPBI (10)/ Al (100)

onde as espessuras, em parênteses, são expressas em nanômetros.

As curvas características de $\mathrm{J} \times \mathrm{V}$ dos dispositivos fotovoltaicos orgânicos fabricados com os substratos de vidro e, vidro e substratos de PVA, PVC e BC com ITO, no escuro e sob iluminação, são mostradas nos gráficos da Figura 73.
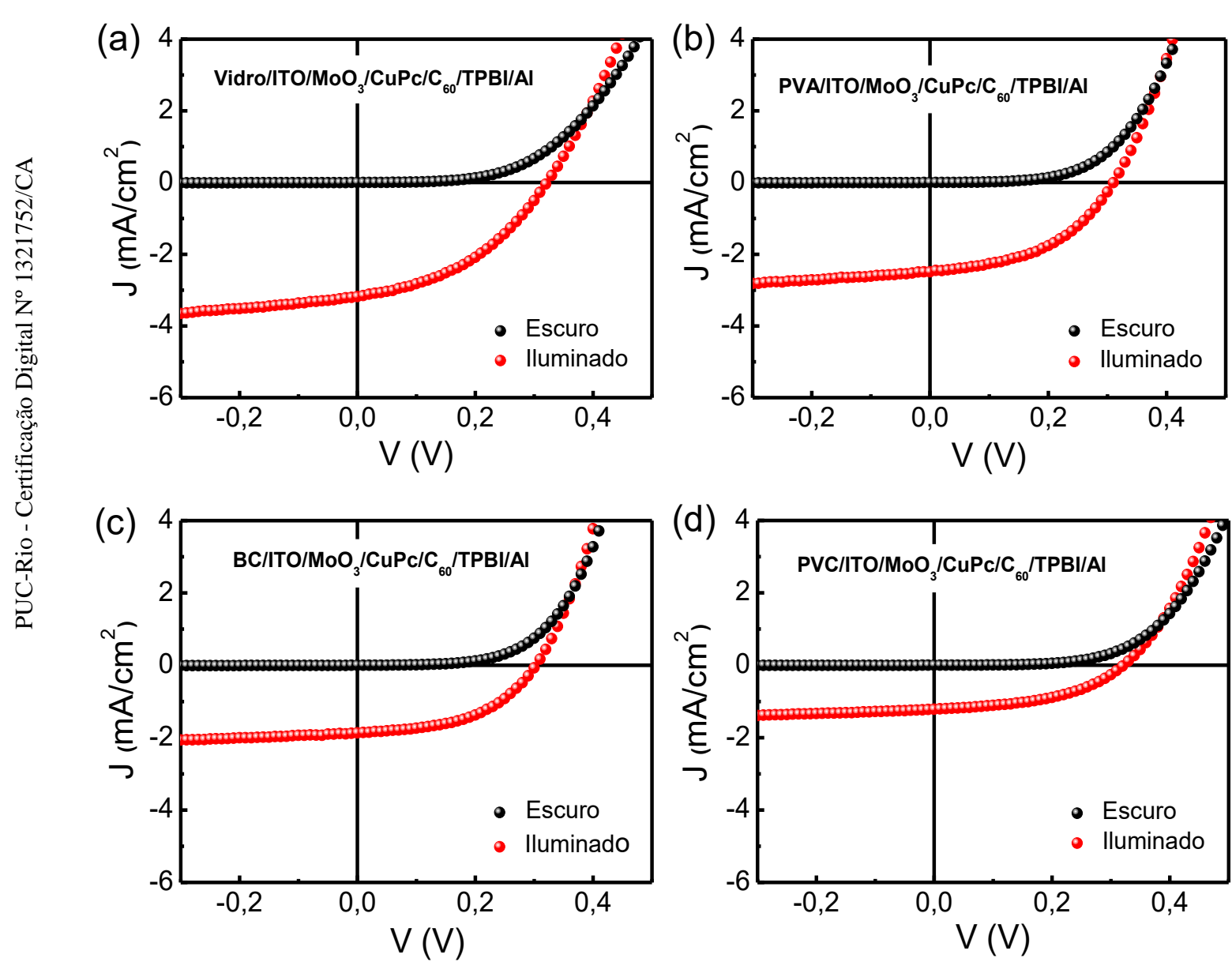

Figura 73: Curvas características de densidade de corrente versus tensão aplicada $(\mathrm{J} \times \mathrm{V})$ aos dispositivos com estrutura tipo substrato/eletrodo/ $\mathrm{MoO}_{3} / \mathrm{CuPc} / \mathrm{C}_{60} / \mathrm{TPBI} / \mathrm{Al}$, com os seguintes substratos/eletrodo: (a) Vidro/ITO; (b) PVA/ITO; (c) BC/ITO; (d) PVC/ITO. 
Os valores dos parâmetros típicos usados na caracterização dos dispositivos fotovoltaicos orgânicos, os quais foram extraídos a partir das curvas características de $\mathrm{J} \times \mathrm{V}$, são mostrados na Tabela 13.

Tabela 13: Sumário com os principais parâmetros obtidos a partir das curvas $\mathrm{J} \times \mathrm{V}$ dos dispositivos com estrutura substrato/eletrodo/ $\mathrm{MoO}_{3} / \mathrm{CuPc} / \mathrm{C}_{60} / \mathrm{TPBI} / \mathrm{Al}$, mostradas na Figura 73.

\begin{tabular}{ccccc} 
Substrato/Eletrodo & Voc $(\mathbf{V})$ & Jsc $\left(\mathbf{m A} / \mathbf{c m}^{2}\right)$ & FF (\%) & PCE (\%) \\
\hline Vidro/ITO & 0,32 & 3,1 & 46 & 0,41 \\
PVA/ITO & 0,31 & 2,4 & 50 & 0,37 \\
BC/ITO & 0,30 & 1,9 & 49 & 0,28 \\
PVC/ITO & 0,32 & 1,2 & 50 & 0,19 \\
\hline
\end{tabular}

Neste caso, os dispositivos com heterojunção em bicamada apresentaram valores de $\mathrm{V}_{\mathrm{OCS}}$ semelhantes entre si, porém com um valor menor em comparação aos dispositivos anteriores, os quais continham uma estrutura com heterojunção em volume. Este menor valor de $\mathrm{V}_{\mathrm{OC}}$ dos dispositivos em bicamada, possivelmente está relacionado com uma maior taxa de recombinação de portadores de carga nesta estrutura. $[35,106]$

Os valores de $\mathrm{J}_{\mathrm{SC}}$ foram semelhantes aos dispositivos anteriores comparando o mesmo eletrodo. No entanto, os valores do FF foram maiores, indicando uma melhor qualidade dos dispositivos em bicamada e, consequentemente, resultando em uma eficiência de conversão de potência maior.

Dispositivo com heterojunção em tricamada $\left(\mathrm{CuPc} / \mathrm{SnPc} / \mathrm{C}_{60}\right)$, sem camadas intermediárias

Com objetivo de aumentar ainda mais a eficiência dos dispositivos, acrescentei em sua estrutura uma terceira camada ativa, o SnPc. Este material absorve luz em uma região fora do espectro de absorção do $\mathrm{CuPc}$, portanto, aumentei o espectro de absorção ótica final do dispositivo.

Neste novo dispositivo a camada ativa é substituída por uma heterojunção em tricamada de $\mathrm{CuPc}, \mathrm{SnPc}$ e $\mathrm{C}_{60}\left(\mathrm{CuPc} / \mathrm{SnPc} / \mathrm{C}_{60}\right)$, e não utilizei camadas intermediárias transportadora/injetora de elétrons e buracos. Com essas alterações, os dispositivos foram fabricados de acordo com a seguinte estrutura: 


\section{Substrato/ITO/CuPc (15)/ SnPc (15)/ C60 (40)/ Al (100)}

onde as espessuras, em parênteses, são expressas em nanômetros.

As curvas características $\mathrm{J} \times \mathrm{V}$ dos dispositivos fotovoltaicos orgânicos fabricados em estrutura tipo tricamada são apresentados na Figura 74. Nesta figura são apresentados os resultados de dispositivos fotovoltaicos orgânicos fabricados com os substratos de vidro e, vidro e substratos de PVA, BC com ITO, no escuro e sob iluminação.
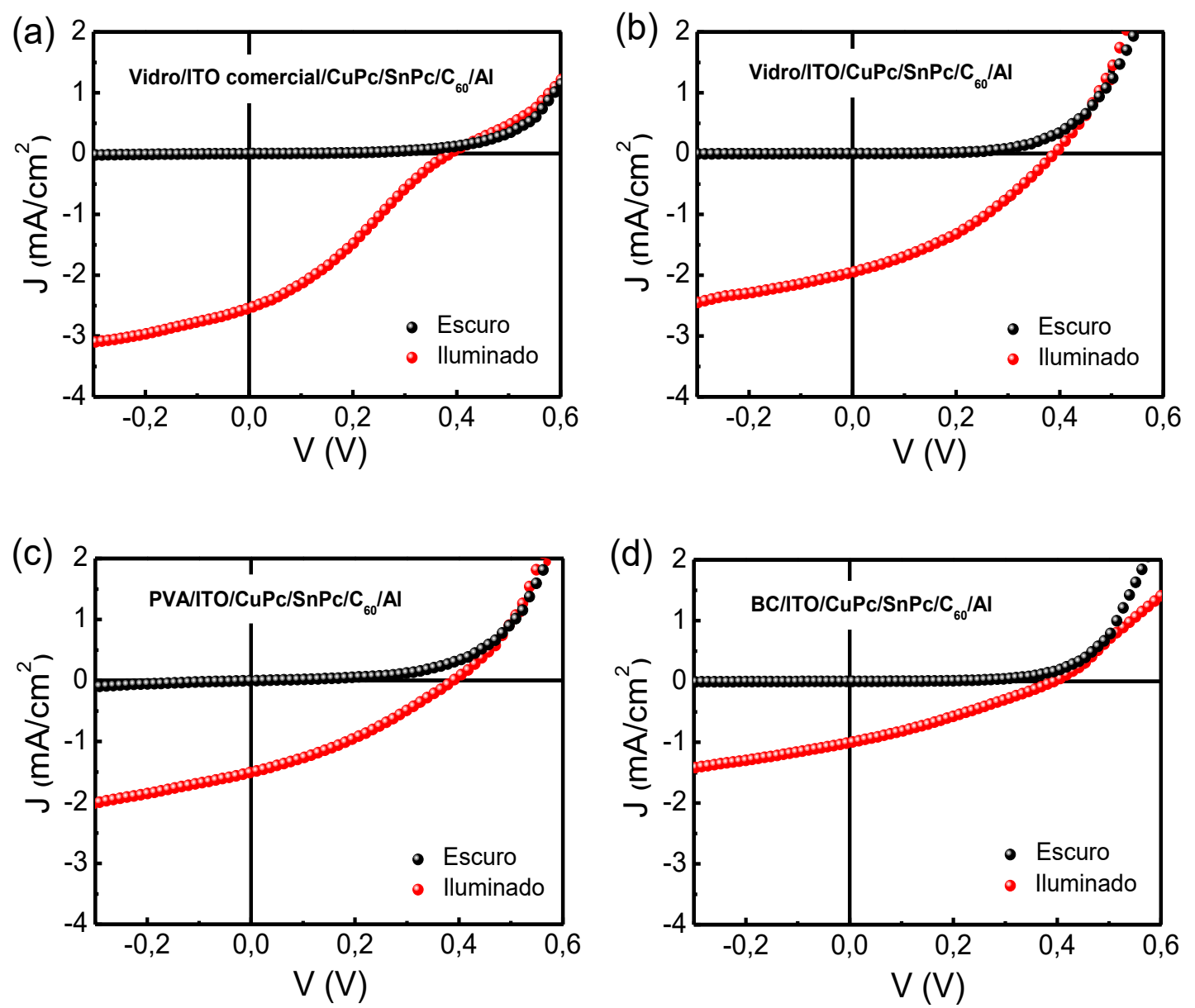

Figura 74: Curvas características de densidade de corrente versus tensão aplicada $(\mathrm{J} \times \mathrm{V})$ aos dispositivos com estrutura tipo substrato/eletrodo/CuPc $(15 \mathrm{~nm}) / \mathrm{SnPc}(15 \mathrm{~nm}) / \mathrm{C}_{60}(40 \mathrm{~nm}) / \mathrm{Al}(100 \mathrm{~nm})$, com os seguintes substratos/eletrodo: (a) Vidro/ITO comercial; (b) Vidro/ITO; (c) PVA/ITO; (d) BC/ITO.

Importante destacar na Figura 74 (a) a formação de um fenômeno, conhecido como "formato S" (S-shape, no inglês) presente na curva tipo $\mathrm{J} \times \mathrm{V}$ sob iluminação. Este comportamento ocorre por diversos fatores que afetam a extração de elétrons próximos ao catodo do dispositivo. Tais fatores podem incluir recombinação na superfície, bloqueio parcial de contatos causados nas camadas interfaciais ou separação de fases ao longo do dispositivo. [107, 108] 
Os valores dos parâmetros típicos usados na caracterização dos dispositivos fotovoltaicos orgânicos, os quais foram extraídos a partir das curvas características $\mathrm{J} \times \mathrm{V}$, são mostrados na Tabela 14.

Tabela 14: Sumário com os principais parâmetros obtidos a partir das curvas $\mathrm{J} \times \mathrm{V}$ dos dispositivos com estrutura substrato/eletrodo/CuPc/SnPc/C60 $/ \mathrm{Al}$, mostradas na Figura 74.

\begin{tabular}{ccccc} 
Substrato/Eletrodo & Voc $(\mathbf{V})$ & Jsc $\left(\mathbf{m A} / \mathbf{c m}^{2}\right)$ & FF $(\%)$ & PCE (\%) \\
\hline Vidro/ITO comercial & 0,39 & 2,4 & 32 & 0,30 \\
Vidro/ITO & 0,39 & 2,0 & 34 & 0,27 \\
PVA/ITO & 0,39 & 1,5 & 33 & 0,19 \\
BC/ITO & 0,39 & 1,0 & 31 & 0,12 \\
\hline
\end{tabular}

Os dispositivos com estrutura em tricamada apresentaram valores de VoCS semelhantes entre si, porém com valor superior em relação aos dispositivos, os quais continham uma estrutura com heterojunção em bicamada e em volume de $\mathrm{CuPc}$ e $\mathrm{C}_{60}$. Visto que os materiais que compõem a camada ativa não foram modificados, mantendo os valores de HOMO e LUMO, essa diferença pode estar associada a densidade de portadores de cargas, em concordância com a Equação 1. Por outro lado, o valor da $\mathrm{J}_{\mathrm{SC}}$ para o substrato de vidro/ITO permanece sendo superior aos substratos poliméricos/ITO, o qual depende fortemente das propriedades físicas do substrato, em concordância com os resultados anteriores.

Os valores de $\mathrm{J}_{\mathrm{SC}}$ e FF foram menores ou da mesma ordem dos demais dispositivos, acarretando em uma eficiência inferior, resultando em uma PCE inferior. Porém esse valor inferior da PCE pode ser devido a não utilização das camadas transportadoras de elétrons e buracos (TPBI e $\mathrm{MoO}_{3}$ ) na estrutura dos dispositivos fotovoltaicos orgânicos e, portanto, apresentarei esses resultados na sequência.

Dispositivos com heterojunção em tricamada $\left(\mathrm{CuPc} / \mathrm{SnPc} / \mathrm{C}_{60}\right)$ e simultaneamente em volume e em bicamada ( $\left.\mathrm{CuPc}: \mathrm{SnPc} / \mathrm{C}_{60}\right)$

Fabriquei dispositivos semelhante à estrutura anterior, contudo acrescentei na sua estrutura uma camada de um material transportador de buraco, o $\mathrm{MoO}_{3}$, e uma camada transportadora de elétrons, o TPBI. 
Fabriquei um dispositivo com estrutura em tricamada de $\mathrm{CuPc}, \mathrm{SnPc}$ e $\mathrm{C}_{60}$ $\left(\mathrm{CuPc} / \mathrm{SnPc} / \mathrm{C}_{60}\right)$ e outro com estrutura simultaneamente em volume de $\mathrm{CuPc}$ e $\mathrm{SnPc}$ (CuPc:SnPc) e em bicamada de (CuPc:SnPc) e $\mathrm{C}_{60}\left(\mathrm{CuPc}: \mathrm{SnPc}_{\mathrm{C}} \mathrm{C}_{60}\right)$.

Com essas alterações, os dispositivos foram fabricados de acordo com as seguintes estruturas:

(i) Vidro/ ITO/ $\mathrm{MoO}_{3}$ (5)/ CuPc (15):SnPc (15)/ C60 (40)/ TPBI (10)/ Al (100)

(ii) Vidro/ ITO/ $\mathrm{MoO}_{3}$ (5)/ CuPc (15)/SnPc (15)/ C60 (40)/ TPBI (10)/ Al (100) onde as espessuras, em parênteses, são expressas em nanômetros.

As curvas características de $\mathrm{J} \times \mathrm{V}$ dos dispositivos fotovoltaicos orgânicos fabricados, apenas com substratos de vidro com ITO comercial, no escuro e sob iluminação, são mostradas nos gráficos da Figura 75. Os valores dos parâmetros típicos usados na caracterização dos dispositivos fotovoltaicos orgânicos, os quais foram extraídos a partir das curvas características de $\mathrm{J} \times \mathrm{V}$, são mostrados na Tabela 15 .

(a)

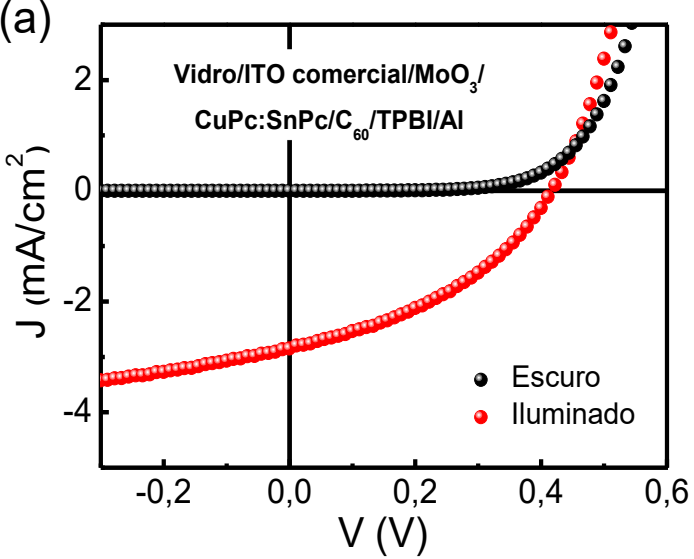

(b)

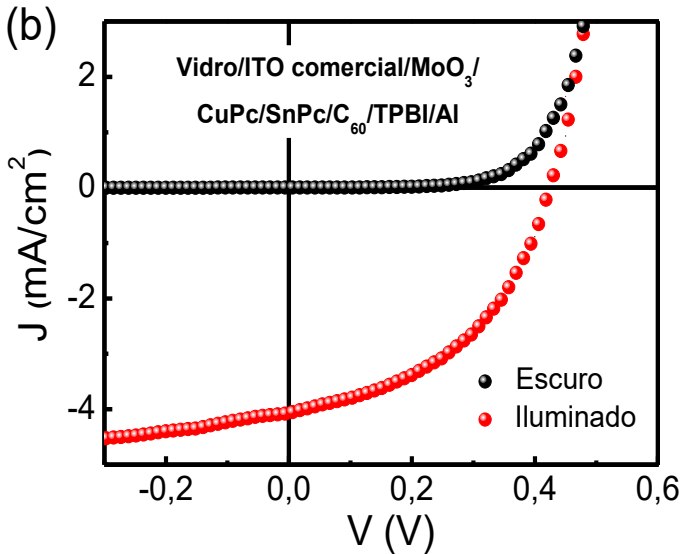

Figura 75: Curvas características de densidade de corrente versus tensão aplicada $(\mathrm{J} \times \mathrm{V})$ aos dispositivos com estrutura tipo vidro/ITO comercial/ $\mathrm{MoO}_{3}(5 \mathrm{~nm}) /$ camada ativa $(70 \mathrm{~nm}) / \mathrm{TPBI}(10 \mathrm{~nm}) / \mathrm{Al}(100 \mathrm{~nm})$ com camada ativa em heterojunção (a) simultaneamente em volume e em bicamada $\left(\mathrm{CuPc}: \mathrm{SnPc} / \mathrm{C}_{60}\right)$ e (b) em tricamada $\left(\mathrm{CuPc} / \mathrm{SnPc} / \mathrm{C}_{60}\right)$.

Tabela 15: Sumário com os principais parâmetros obtidos a partir das curvas $\mathrm{J} \times \mathrm{V}$ dos dispositivos com estrutura vidro/ITO comercial/MoO $3 /$ camada ativa/TPBI/Al, mostradas na Figura 75.

\begin{tabular}{lcccc} 
Camada ativa & Voc $(\mathbf{V})$ & Jsc $(\mathbf{m A} / \mathbf{c m} 2)$ & FF (\%) & PCE (\%) \\
\hline $\mathrm{CuPc}: \mathrm{SnPc} / \mathrm{C}_{60}$ & 0,42 & 2,8 & 39 & 0,46 \\
$\mathrm{CuPc} / \mathrm{SnPc} / \mathrm{C}_{60}$ & 0,42 & 4,1 & 46 & 0,79 \\
\hline
\end{tabular}


Os dispositivos com estrutura em tricamada e simultaneamente em volume e bicamada apresentaram valores de $\mathrm{V}_{\mathrm{OCS}}$ semelhantes entre si, porém os valores de $\mathrm{J}_{\mathrm{SC}} \mathrm{e}$ FF foram maiores para a estrutura em tricamada $\left(\mathrm{CuPc} / \mathrm{SnPc} / \mathrm{C}_{60}\right)$, resultando em uma PCE maior. Em comparação a estrutura anterior sem as camadas de $\mathrm{MoO}_{3}$ e TPBI todos os parâmetros apresentaram um aumento, com a PCE indo de 0,30\% para 0,79\% para o dispositivo com substratos de vidro/ITO comercial.

Como o resultado do dispositivo fotovoltaico orgânico com estrutura em tricamada com camada intermediaria de $\mathrm{MoO}_{3}$ e TPBI foi o que apresentou o melhor resultado sobre substrato de vidro/ITO comercial, fabriquei essa mesma estrutura sobre os substratos híbridos de vidro/ITO comercial (novamente), vidro/ITO, PVA/ITO e BC/ITO. Devido a limitação de fabricação de apenas 4 amostras no sistema de deposição do LOEM, nesta etapa do trabalho o substrato de PVC não foi utilizado. Além disso, o dispositivo com substrato de PVA/ITO não apresentou os resultados pretendidos, não se comportando como um dispositivo fotovoltaico. Na Figura 76 as curvas características de $\mathrm{J} \times \mathrm{V}$ para os dispositivos com substratos de vidro/ITO e BC/ITO são mostradas, no escuro e sob iluminação.

Os valores dos parâmetros típicos usados na caracterização dos dispositivos fotovoltaicos orgânicos, os quais foram extraídos a partir das curvas características de $\mathrm{J} \times \mathrm{V}$, são mostrados na Tabela 16 .
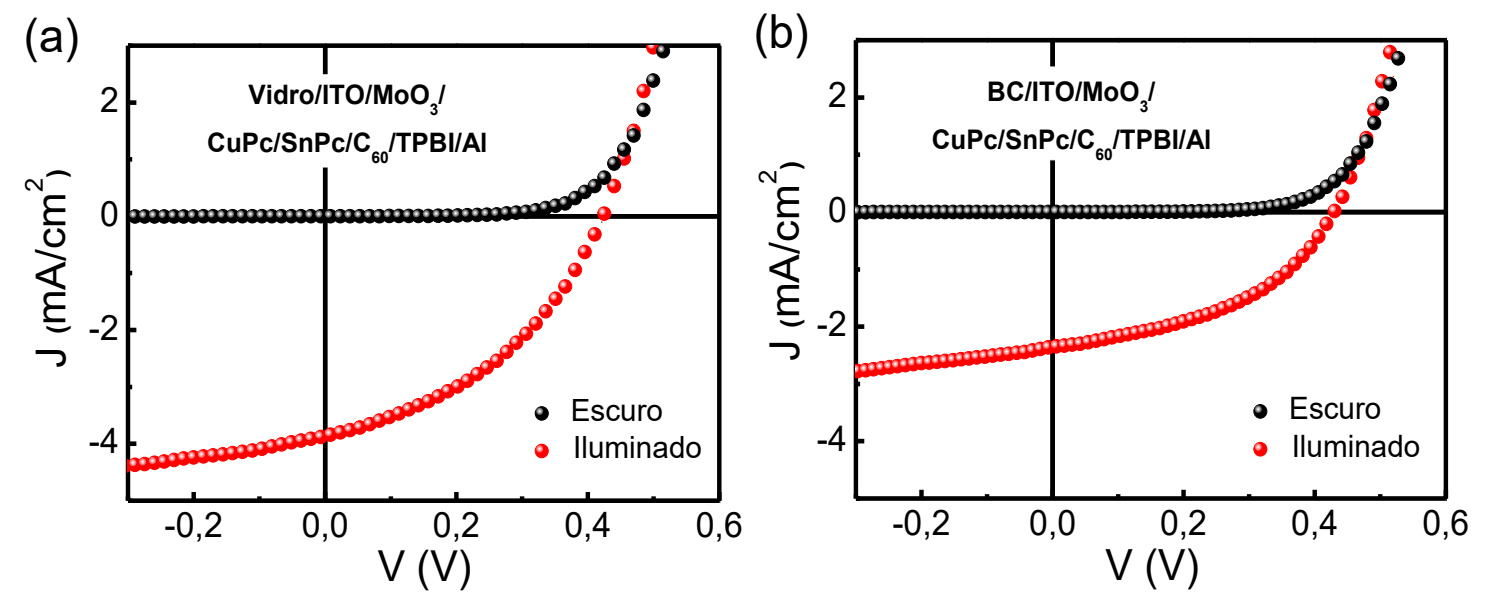

Figura 76: Curvas características de densidade de corrente versus tensão aplicada $(\mathrm{J} \times \mathrm{V})$ aos dispositivos com estrutura tipo substrato/ITO/ $\mathrm{MoO}_{3}(5 \mathrm{~nm}) / \mathrm{CuPc}(15 \mathrm{~nm}) / \mathrm{SnPc}(15 \mathrm{~nm}) / \mathrm{C}_{60}(40 \mathrm{~nm}) / \mathrm{TPBI}(10 \mathrm{~nm}) / \mathrm{Al}$ (100nm), com os seguintes substratos: (a) Vidro e (b) BC. 
Tabela 16: Sumário com os principais parâmetros obtidos a partir das curvas $\mathrm{J} \times \mathrm{V}$ dos dispositivos com estrutura substrato/eletrodo/ $\mathrm{MoO}_{3} / \mathrm{CuPc} / \mathrm{SnPc} / \mathrm{C}_{60} / \mathrm{TPBI} / \mathrm{Al}$, mostradas nas Figuras 75 (b) e 76.

\begin{tabular}{ccccc} 
Substrato/Eletrodo & Voc $(\mathbf{V})$ & Jsc $(\mathbf{m A} / \mathbf{c m} 2)$ & FF $(\%)$ & PCE (\%) \\
\hline Vidro/ ITO comercial & 0,42 & 4,1 & 46 & 0,79 \\
Vidro/ ITO & 0,42 & 3,8 & 41 & 0,66 \\
BC/ITO & 0,43 & 2,4 & 45 & 0,45 \\
PVA/ITO & - & - & - & - \\
\hline
\end{tabular}

$\underline{\text { Testes mecânicos (flexibilidade) em substratos poliméricos }}$

Foram realizados testes mecânicos preliminares de flexibilidade com o dispositivo flexível com substrato de BC afim de observar o quanto o filme de ITO suporta a flexão em determinados diâmetros.

A Figura 77 mostra um dispositivo fotovoltaico orgânico sendo flexionado em diâmetros de 30, 25, 20 e $15 \mathrm{~mm}$, respectivamente.
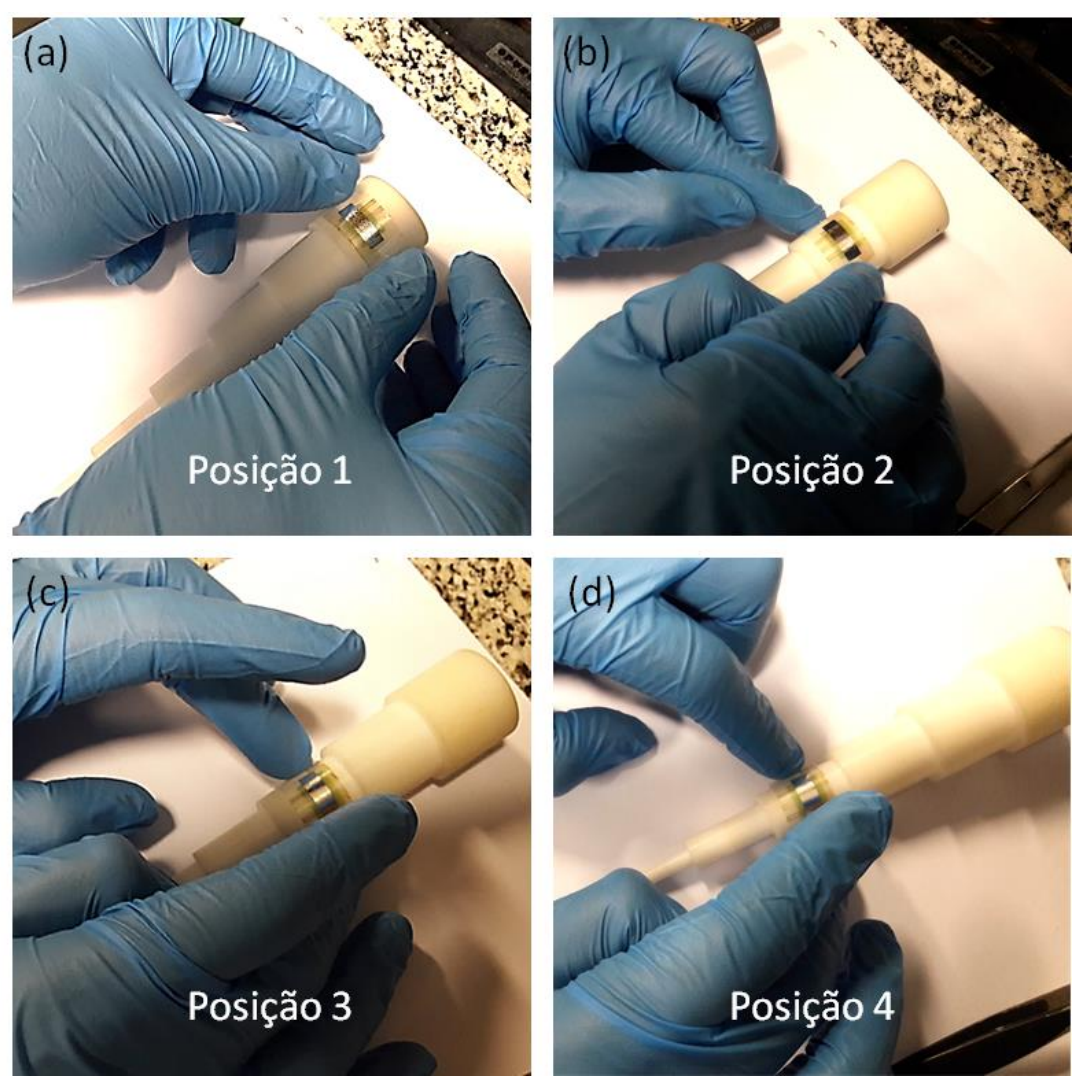

Figura 77: Imagem mostrando o teste de flexão realizado em um dispositivo fotovoltaico orgânico com substrato polimérico de BC: (a) Na posição $1 \mathrm{com} 30 \mathrm{~mm}$ de diâmetro; (b) Na posição 2 com $25 \mathrm{~mm}$ de diâmetro; (c) Na posição 3 com 20 mm de diâmetro; e (d) Na posição 4 com 15 mm de diâmetro. 
Após cada processo de flexão em determinado diâmetro, o dispositivo fotovoltaico orgânico foi caracterizado a partir de sua curva $J \times V$. A Figura 78 mostra as curvas $J \times V$ do dispositivo fotovoltaico orgânico antes de ser flexionado e após as flexões nas quatro posições com diâmetros diferentes. Os valores dos seus parâmetros típicos para a caracterização dos dispositivos fotovoltaicos orgânicos, os quais foram extraídos a partir das curvas características de $\mathrm{J} \times \mathrm{V}$, são mostrados na Tabela 17 .

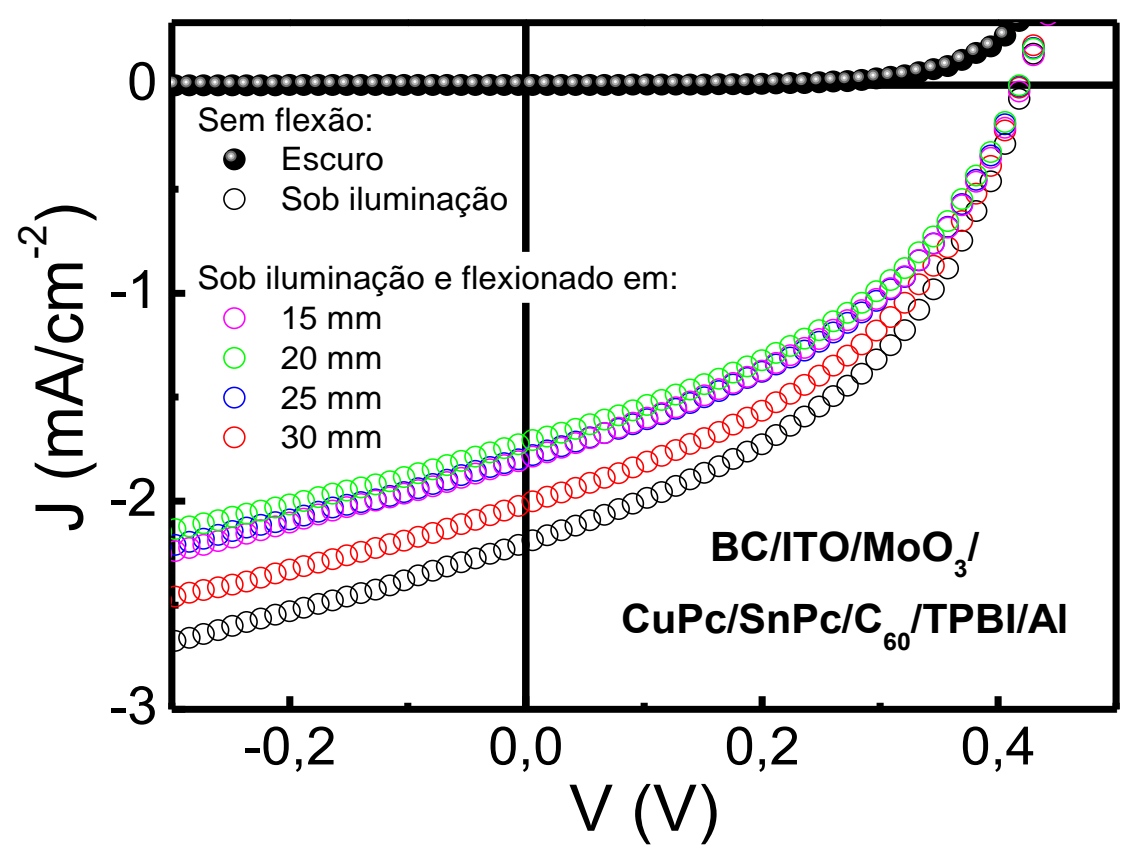

Figura 78: Densidade de corrente versus tensão $(\mathrm{J} \times \mathrm{V})$ das curvas do dispositivo com estrutura $\mathrm{BC} / \mathrm{ITO} / \mathrm{MoO}_{3} / \mathrm{CuPc} / \mathrm{SnPc} / \mathrm{C}_{60} / \mathrm{TPBI} / \mathrm{Al}$ submetido a diferentes diâmetros de flexão $(15,20,25$ e 30 mm).

Tabela 17: Sumário com os principais parâmetros obtidos das curvas $\mathrm{J} \times \mathrm{V}$ do dispositivo com estrutura $\mathrm{BC} / \mathrm{ITO} / \mathrm{MoO}_{3} / \mathrm{CuPc} / \mathrm{SnPc} / \mathrm{C}_{60} / \mathrm{TPBI} / \mathrm{Al}$ mostrada na Figura 78 , para as diferentes posições de flexão.

\begin{tabular}{cccccc}
\hline Posição & $\begin{array}{c}\text { Diâmetro de flexão } \\
(\mathbf{m m})\end{array}$ & Voc $(\mathbf{V})$ & JsC $(\mathbf{m A} / \mathbf{c m} 2)$ & FF (\%) & PCE (\%) \\
\hline Plana & - & 0,42 & 2,2 & 43 & 0,40 \\
1 & 30 & 0,42 & 2,0 & 43 & 0,36 \\
2 & 25 & 0,42 & 1,8 & 41 & 0,31 \\
3 & 20 & 0,42 & 1,7 & 42 & 0,30 \\
4 & 15 & 0,42 & 1,8 & 41 & 0,31
\end{tabular}


Após o processo de flexão nas quatro posições com diferentes diâmetros, o processo foi repetido novamente, mas com 10 flexões em cada posição. A Figura 79 mostra as curvas $\mathrm{J} \times \mathrm{V}$ do dispositivo fotovoltaico orgânico antes de ser flexionado e após as flexões nas quatro posições com diâmetros diferentes. Os valores dos seus parâmetros típicos para a caracterização dos dispositivos fotovoltaicos orgânicos, os quais foram extraídos a partir das curvas características de $\mathrm{J} \times \mathrm{V}$, são mostrados na Tabela 18 .

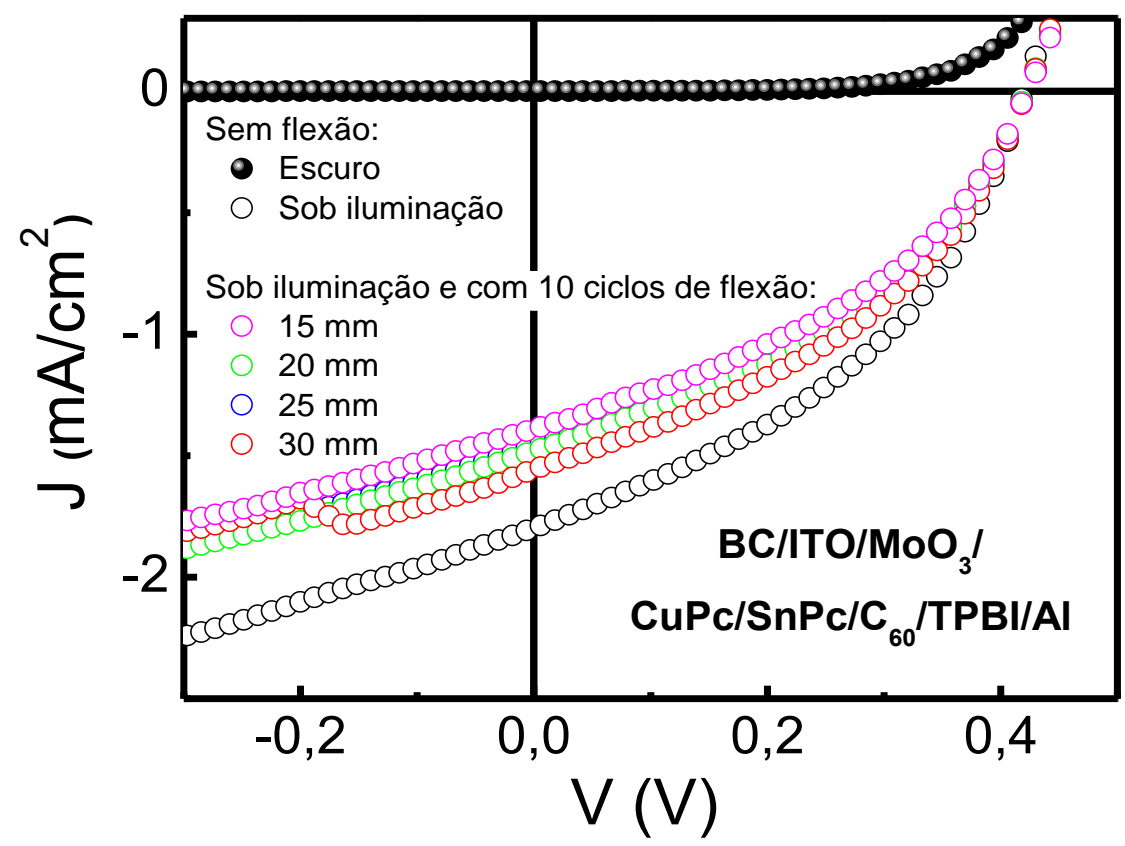

Figura 79: Densidade de corrente versus tensão $(\mathrm{J} \times \mathrm{V})$ das curvas do dispositivo com estrutura $\mathrm{BC} / \mathrm{ITO} / \mathrm{MoO}_{3} / \mathrm{CuPc} / \mathrm{SnPc} / \mathrm{C}_{60} / \mathrm{TPBI} / \mathrm{Al}$ submetido a 10 ciclos em cada diâmetro de flexão (15, 20, 25 e 30 $\mathrm{mm})$.

Tabela 18: Sumário com os principais parâmetros obtidos das curvas $\mathrm{J} \times \mathrm{V}$ do dispositivo com estrutura $\mathrm{BC} / \mathrm{ITO} / \mathrm{MoO}_{3} / \mathrm{CuPc} / \mathrm{SnPc} / \mathrm{C}_{60} / \mathrm{TPBI} / \mathrm{Al}$ mostrada na Figura 79 , com 10 ciclos de flexão para as diferentes posições.

\begin{tabular}{cccccc}
\hline Posição & $\begin{array}{c}\text { Diâmetro de flexão } \\
(\mathbf{m m})\end{array}$ & Voc $(\mathbf{V})$ & $\mathbf{J S C}\left(\mathbf{m A} / \mathbf{c m}^{2}\right)$ & $\mathbf{F F}(\%)$ & $\begin{array}{c}\text { PCE } \\
(\%)\end{array}$ \\
\hline Plana & - & 0,42 & 1,8 & 41 & 0,31 \\
1 & 30 & 0,42 & 1,6 & 40 & 0,27 \\
2 & 25 & 0,42 & 1,5 & 40 & 0,25 \\
3 & 20 & 0,42 & 1,5 & 40 & 0,25 \\
4 & 15 & 0,42 & 1,4 & 41 & 0,24
\end{tabular}


O dispositivo fotovoltaico orgânico fabricado sobre o substrato flexível de BC foi novamente caracterizado a partir da sua curva $\mathrm{J} \times \mathrm{V}$, após dois e cinco dias. Na Figura 80 (a) são mostradas as curvas $\mathrm{J} \times \mathrm{V}$ antes do dispositivo ser submetido a qualquer ciclo de flexão e após completar 10 ciclos de flexões/extensão na posição 4 do cilindro, equivalente à $15 \mathrm{~mm}$ de diâmetro. Observa-se que a $\mathrm{V}_{\text {OC }}$ não teve alteração, enquanto a J $\mathrm{SC}_{\mathrm{S}}$ a PCE diminuíram consideravelmente em comparação às medidas realizadas há dois dias. Esta diminuição da $\mathbf{J}_{\mathrm{SC}}$ com o tempo está diretamente relacionada com o aumento da resistência elétrica do eletrodo e, principalmente, das camadas orgânicas.

Na Figura 80 (b) são mostradas as curvas $J \times V$ no escuro e sob iluminação sem o dispositivo ter sido submetido ao ciclo de flexão/extensão. Observamos que a $\mathbf{J}_{\mathrm{SC}}$ e a PCE diminuíram drasticamente em comparação às medidas realizadas há 5 dias.

(a)

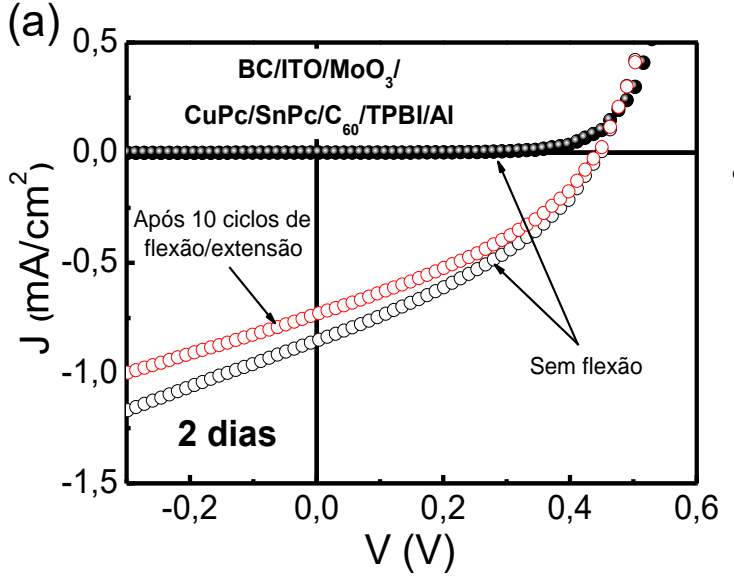

(b)

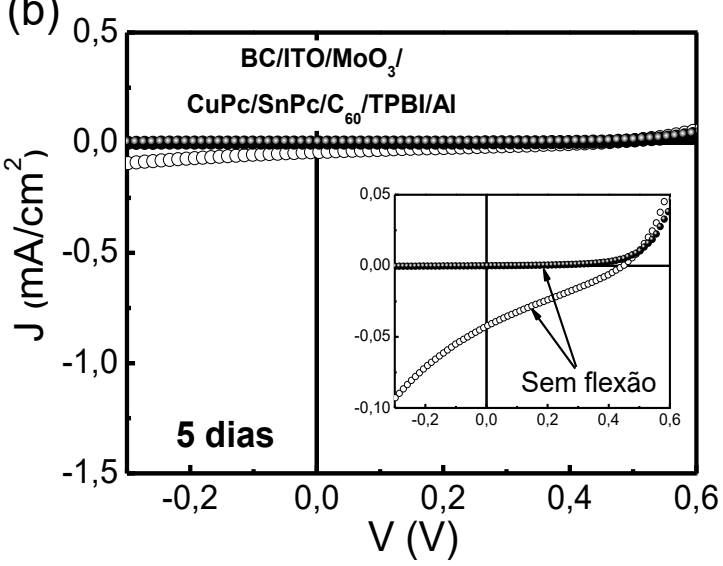

Figura 80: Densidade de corrente versus tensão $(\mathrm{J} \times \mathrm{V})$ das curvas do dispositivo com estrutura $\mathrm{BC} / \mathrm{ITO} / \mathrm{MoO}_{3} / \mathrm{CuPc} / \mathrm{SnPc} / \mathrm{C}_{60} / \mathrm{TPBI} / \mathrm{Al}$ : (a) após 2 dias sem flexão e com 10 ciclos de flexão na posição 4 do cilindro com $15 \mathrm{~nm}$ de diâmetro; e (b) após 5 dias sem flexão de flexão.

A Tabela 19 mostra os valores dos parâmetros típicos para a caracterização dos dispositivos fotovoltaicos orgânicos mostradas nas Figuras 79 e 80, após 0, 2 e 5 dias sem e com ciclos de flexão com diâmetro de $15 \mathrm{~mm}$. 
Tabela 19: Sumário com os principais parâmetros obtidos das curvas $\mathrm{J} \times \mathrm{V}$ do dispositivo com estrutura $\mathrm{BC} / \mathrm{ITO} / \mathrm{MoO}_{3} / \mathrm{CuPc} / \mathrm{SnPc} / \mathrm{C}_{60} / \mathrm{TPBI} / \mathrm{Al}$ mostradas nas Figuras 79 e 80, após 0, 2 e 5 dias sem e com ciclos de flexão com diâmetro de $15 \mathrm{~mm}$.

\begin{tabular}{cccccc}
$\begin{array}{c}\text { Tempo } \\
(\text { dias })\end{array}$ & $\begin{array}{c}\text { Ciclos de } \\
\text { flexão/extensão }\end{array}$ & Jsc (mA/cm2) & Voc $(\mathbf{V})$ & FF (\%) & PCE (\%) \\
\hline 0 & - & 1,8 & 0,42 & 41 & 0,31 \\
0 & 10 & 1,4 & 0,42 & 41 & 0,24 \\
2 & - & 0,86 & 0,42 & 37 & 0,135 \\
2 & 10 & 0,73 & 0,42 & 38 & 0,116 \\
5 & - & 0,043 & 0,42 & 28 & 0,005 \\
\hline
\end{tabular}

As reduções dos valores de JSC, e, consequentemente, da PCE, após 10 ciclos de flexões/extensão podem estar relacionadas tanto ao aumento da resistência elétrica do eletrodo de ITO, quando à falha na adesão entre as camadas adjacentes. Isso porque os ciclos de deformação mecânica podem causar falhas estruturais no ITO, o qual é mecanicamente frágil, em relação à camada ativa que possui maior capacidade de deformação mecânica [109]. Entre diversas falhas estruturais, pode-se citar as rachaduras, cisalhamentos ou aumento de contornos de grãos cristalinos, os quais atuam como barreira energética para o transporte de carga.

Além disso, a adesão entre o filme de ITO, o qual é predominantemente policristalino, e a camada ativa, a qual contem regiões cristalinas e amorfas coexistindo, fica prejudicada após o esforço mecânico, visto que as deformações causadas ultrapassam o regime de deformação elástica para a plástica, não sendo possível retornar o dispositivo ao posicionamento original sem a presença de defeitos mecânicos, como a falha de adesão original [109].

E ainda, os materiais orgânicos sofrem degradação ao longo do tempo por diversos fatores, tal como a temperatura, humidade e exposição à luz, o que está em concordância com o aumento da resistência elétrica e, consequentemente, à diminuição da $\mathrm{J}_{\mathrm{SC}}$ dos dispositivos após 5 dias. 


\section{Considerações finais}

Neste trabalho de doutorado tive o objetivo de desenvolver e caracterizar eletrodos à base de grafeno e substratos híbridos flexíveis à base de polímeros recobertos com um filme fino condutor de ITO, para ser aplicados em dispositivos fotovoltaicos orgânicos. Para isso pude contar com a infraestrutura e competência de dois distintos laboratórios de pesquisa (Lador/Inmetro e Loem/PUC-Rio) e, portanto, ter acesso a atividades experimentais complementares utilizando diferentes sistemas de fabricação de dispositivos orgânicos, e técnicas de caracterização.

Na primeira etapa deste doutoramento potencializei o uso do sistema de deposição química em fase de vapor (CVD) do Inmetro para a produção de grafeno de alta qualidade, a partir da investigação de diversos parâmetros que influenciam o seu crescimento. Os filmes de grafeno foram crescidos em substratos de cobre e posteriormente transferidos para substratos de vidro para serem aplicados em dispositivos fotovoltaicos orgânicos.

Nesta etapa, além de utilizar o processo tradicional de transferência de grafeno, com o polímero PMMA como suporte mecânico, desenvolvi também uma nova metodologia de transferência. Nesta metodologia utilizei uma blenda condutora de EPDM-PAni em substituição ao PMMA, a qual não precisa ser removida ao final do processo de transferência, simplificando este processo. Neste novo método de transferência desenvolvido o produto final é um eletrodo de grafeno/EPDM-PAni sobre um substrato desejado, no nosso caso o vidro.

Além de simplificar o processo de transferência, o uso da blenda de EPDM-PAni resultou na formação de um processo de dopagem do grafeno, o qual maximizou suas propriedades para o uso como eletrodo em dispositivos fotovoltaicos orgânicos. Estes resultados deram origem a um artigo que foi publicado no periódico Chemical Engineering Journal [13] e no capítulo 8 da $1^{\text {a }}$ Ed. do livro Polyaniline Blends, Composites, and Nanocomposite [66].

Em uma segunda etapa deste doutoramento foram fabricados e otimizados diferentes substratos híbridos à base de polímeros de PVC, PVA e celulose bacteriana 
(BC) recobertos com ITO, o qual atua como eletrodo para a aplicação em dispositivos fotovoltaicos orgânicos flexíveis.

Por fim, foram fabricadas diversas estruturas de dispositivos fotovoltaicos orgânicos tanto com heterojunção em bicamada, quanto em volume, para os diferentes eletrodos: grafeno, grafeno/EPDM-PAni e substratos poliméricos híbridos. Estes dispositivos foram caracterizados principalmente através das suas curvas características $\mathrm{J} \times \mathrm{V}$, no escuro e sob iluminação. Além disso, foram realizados ciclos de flexão/extensão de alguns dispositivos a fim de avaliar seu comportamento frente aos esforços mecânicos a estes submetidos.

Os dispositivos com eletrodos à base de grafeno foram fabricados e caracterizados de modo a investigar a potencialidade de uso dos filmes de grafeno e de grafeno/EPDMPAni como eletrodos transparentes condutores em dispositivos fotovoltaicos orgânicos. Os resultados obtidos mostraram que os filmes com grafeno fabricados são promissores para a aplicação em dispositivos fotovoltaicos orgânicos, porém suas propriedades elétrica e morfológica precisam ser aperfeiçoadas para maximizar o desempenho dos dispositivos.

Em relação aos substratos poliméricos híbridos investigados, observa-se que todos estes podem ser utilizados como substratos flexíveis. Algumas estruturas apresentaram eficiência de conversão de potência próxima de zero, enquanto outras, mais otimizadas, atingiram valores próximos de $1 \%$. De modo geral, os dispositivos com substratos de vidro apresentaram os maiores valores de eficiência de conversão de potência, independentemente da estrutura fabricada. Entre os substratos poliméricos observa-se que o PVA apresentou os melhores resultados, sendo que em alguns casos, com valor muito próximo ao vidro, mas com a vantagem de ser flexível.

Os testes mecânicos preliminares de flexão/extensão realizados em alguns dispositivos fotovoltaicos orgânicos resultaram em uma perda de $33 \%$ na densidade de corrente de curto circuito $\left(\mathrm{J}_{\mathrm{SC}}\right)$ e na eficiência de conversão de potência.

A Figura 81, a seguir, mostra uma visão geral da eficiência de conversão de potência (PCE) de cada dispositivo em função dos distintos substratos poliméricos híbridos utilizados para cada estrutura investigada neste trabalho.

Os resultados apresentados são coerentes entre si e dependem fortemente da estrutura do dispositivo fabricado. Os dispositivos fotovoltaicos orgânicos fabricados com estrutura tipo heterojunção em bicamada de $\mathrm{CuPc}$ e $\mathrm{C}_{60}$ (pontos em vermelho) apresentaram maiores valores de PCE, em relação aos dispositivos com heterojunção em 
volume (pontos em azul). Esta significante discrepância deve-se majoritariamente à morfologia não adequada dos filmes orgânicos depositados na estrutura com heterojunção em volume, resultando na recombinação de cargas e perda da PCE.

Os dispositivos fotovoltaicos orgânicos que apresentaram os melhores desempenhos, indicados com pontos laranjas na Figura 81, possuem uma estrutura com heterojunção em tricamada, utilizando dois materiais doadores de elétrons (CuPc e SnPc) e um material como aceitador de elétrons $\left(\mathrm{C}_{60}\right)$. O SnPc foi adicionado na estrutura com o intuito de aumentar a faixa de absorção de luz solar da camada ativa dos dispositivos fotovoltaicos orgânicos, resultando no aumento da PCE.

Os resultados obtidos da investigação dos substratos poliméricos híbridos ainda não foram publicados em periódicos, mas estão em fase de discussão objetivando uma breve submissão.

Por fim, considerando que o objetivo deste trabalho foi a aplicabilidade dos substratos funcionalizados investigados em dispositivos fotovoltaicos orgânicos, e não atingir altos valores de PCE, conclui-se que os resultados finais foram satisfatórios e abrem novas perspectivas para trabalhos futuras, como é sugerido na sequência. 


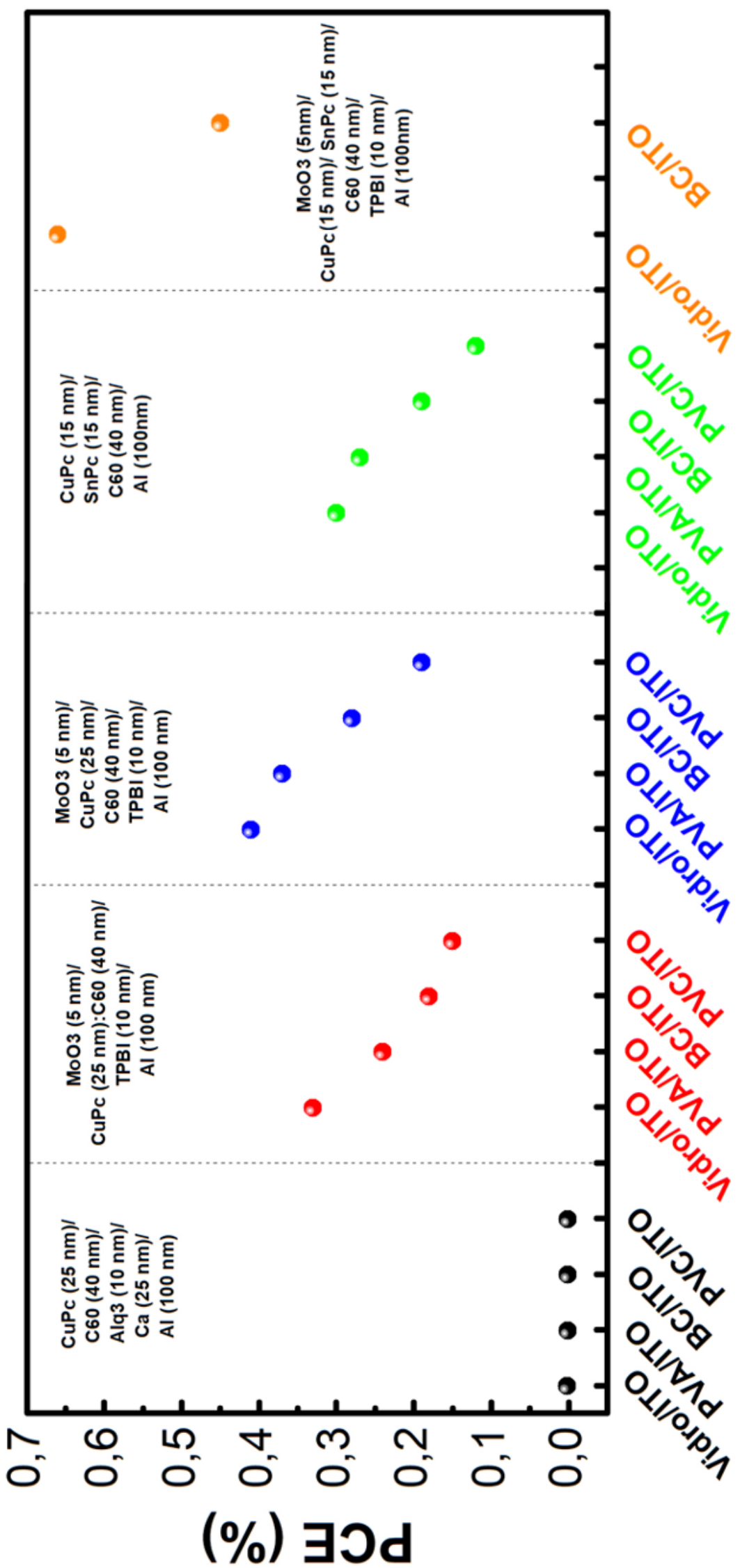

Figura 81: Visão geral dos dispositivos fotovoltaicos orgânicos fabricados e sua respectiva eficiência (PCE). 
$\underline{\text { Sugestões para trabalhos futuros }}$

Dos resultados obtidos percebe-se que os substratos poliméricos funcionalizados podem ser utilizados em dispositivos orgânicos flexíveis. Contudo, estes apresentaram baixa eficiência de conversão de potência. Logo, sugere-se como trabalhos futuros:

- Otimização das camadas orgânicas principalmente no que diz respeito das suas espessuras, a fim de maximizar a eficiência de conversão de potência dos dispositivos fotovoltaicos orgânicos flexíveis;

- Realizar testes mecânicos mais detalhados para melhor descrever sua flexibilidade, resistência à fadiga mecânica, entre outros.

Para melhorar a qualidade dos filmes de grafeno faz-se necessária a automação do sistema de deposição por CVD instalado na Dimat/Inmetro, no qual os medidores de fluxo de gases deverão ser trocados por controladores de fluxo, além da implementação de vácuo no sistema, trazendo maior repetitividade e homogeneidade nos resultados obtidos.

\section{$\underline{\text { Trabalhos, eventos e outras colaborações }}$}

Ao longo deste doutoramento foi possível participar de diversas discussões acadêmicas, as quais produziram resultados publicados em periódico internacional, capítulo de livro e em anais de eventos.

\section{Em revista indexada:}

- De Castro, R.K.; Araujo, J.R.; Valaski, R.; Costa, L.O.O.; Archanjo, B.S.; Fragneaud, B.; M.; Achete, C.A. New transfer method of CVD-grown graphene using a flexible, transparent and conductive polyaniline-rubber thin film for organic electronic applications. Chemical Engineering Journal (1996), v. 273, p. 509-518, 2015.

\section{Em capítulo de livro:}


- Araujo, J. R.; Lopes, E. S.; Castro, R. K.; Senna, C. A.; Robertis, E.; Neves, R. S.; Fragneaud, B.; Nykanen, A.; Kuznetsov, A; Archanjo, B. S.; Paoli, M. A. Characterization of Polyaniline-Based Blends, Composites, and Nanocomposites. Polyaniline Blends, Composites, and Nanocomposites. 1ed.Amsterdam/Oxford/Cambridge: Elsevier, 2017, v. 1, p. 209-234.

Em anais de eventos:

- Rosalia Krüger de Castro; Joyce Rodrigues Araujo; Rogerio Valaski; Lídia Oazem de Oliveira da Costa; Braulio Soares Archanjo; Benjamin Fragneaud; Marco Cremona; Carlos Alberto Achete. CVD-grown graphene transferred onto EPDMPolyaniline for Organic Electronics. XIV SBPMat, 2015, Rio de Janeiro. 2015. p. 61-62.

- Costa LOO; Oliveros ME; de Castro RK; Archanjo BS. Crescimento por deposição na fase vapor (CVD) de grafeno bicamada rodado (tBLG) e identificação dos ângulos de rotação entre camadas por MET e Raman. VIII Congresso de Microscopia de Materiais, 2014, Campinas - SP.

- Joyce Rodrigues Araujo; Rosalia Krüger de Castro; Braulio Soares Archanjo; Rogerio Valaski; Carlos Alberto Achete. EPDM-Polyaniline thin films used to transfer and doping CVD-grown graphene. XIII Encontro da SBPMat, 2014, João Pessoa.

- R. K. de Castro; J.R. Araujo; B. S. Archanjo; M. Cremona. Transparent conductive eletrode based on doped CVD-grown graphene and EPDMPolyaniline thin films. 17th International Conference on Solid Films and Surfaces - ICSFS, 2014, Rio de Janeiro.

- Kuznetsov; L. O. O. Costa; G. Perez; R. K. de Castro; B. S. Archanjo. Effect of deposited graphene layers on microstructural properties of copper foil. 17th International Conference on Solid Films and Surfaces - ICSFS, 2014, Rio de Janeiro. 
Além destes trabalhos, auxiliei a orientadora Lídia Oazem na condução do projeto de iniciação científica de sua aluna de graduação Ingrid Montezuma da Silva, durante 2 anos, resultando inclusive no trabalho abaixo:

- $\quad$ Ingrid Montezuma da Silva; Rosalia Krüger de Castro; Lídia Oazem de Oliveira da Costa; Bráulio Soares Archanjo; Carlos Alberto Achete. Produção e Caracterização de Mono e Multi Camadas de Grafeno Crescidas por CVD. XXXVI Jornada Giulio Massarani de Iniciação Científica, Tecnológica, Artística e Cultural da UFRJ, 2015, Rio de Janeiro. 


\section{Referências bibliográficas}

1. Arias, A.C., et al., Materials and Applications for Large Area Electronics: Solution-Based Approaches. Chemical Reviews, 2010. 110(1): p. 3-24.

2. Tang, C.W., Two-layer organic photovoltaic cell. Applied Physics Letters, 1986. 48(2): p. 183-185.

3. Tang, C.W.V.S.A., Organic electroluminescent diodes. Applied Physics Letters, 1987. 51(12): p. 913 - 915.

4. Yu, G., et al., Polymer Photovoltaic Cells: Enhanced Efficiencies via a Network of Internal Donor-Acceptor Heterojunctions. Science, 1995. 270(5243): p. 17891791.

5. Halls, J.J.M., et al., Efficient photodiodes from interpenetrating polymer networks. Nature, 1995. 376: p. 498.

6. Burroughes, J.H., et al., Light-emitting diodes based on conjugated polymers. Nature, 1990. 347: p. 539.

7. Braun, D. and A.J. Heeger, Visible light emission from semiconducting polymer diodes. Applied Physics Letters, 1991. 58(18): p. 1982-1984.

8. Greenham, N.C., et al., Efficient light-emitting diodes based on polymers with high electron affinities. Nature, 1993. 365: p. 628.

9. Lumb, M.P., et al., GaSb-Based Solar Cells for Full Solar Spectrum Energy Harvesting. Advanced Energy Materials, 2017. 7(20): p. 1700345-n/a.

10. Zhao, W.L., S.; Yao, H.; Zhang, S.; Zhang, Y.; Yang, B.; Hou, J. , Molecular Optimization Enables over 13\% Efficiency in Organic Solar Cells. Journal of the American Chemical Society, 2017. 139(21): p. 7148-7151.

11. Ellmer, K., Past achievements and future challenges in the development of optically transparent electrodes. Nature Photonics, 2012. 6(12): p. 808-816.

12. Wan, X.J., et al., Graphene - A Promising Material for Organic Photovoltaic Cells. Advanced Materials, 2011. 23(45): p. 5342-5358. 
13. de Castro, R.K., et al., New transfer method of CVD-grown graphene using a flexible, transparent and conductive polyaniline-rubber thin film for organic electronic applications. Chemical Engineering Journal, 2015. 273: p. 509-518.

14. Park, H., et al., Graphene As Transparent Conducting Electrodes in Organic Photovoltaics: Studies in Graphene Morphology, Hole Transporting Layers, and Counter Electrodes. Nano Letters, 2012. 12(1): p. 133-140.

15. De Arco, L.G., et al., Continuous, Highly Flexible, and Transparent Graphene Films by Chemical Vapor Deposition for Organic Photovoltaics. Acs Nano, 2010. 4(5): p. 2865-2873.

16. Park, H., et al., Doped graphene electrodes for organic solar cells. Nanotechnology, 2010. 21(50).

17. Wang, Y., et al., Interface Engineering of Layer-by-Layer Stacked Graphene Anodes for High-Performance Organic Solar Cells. Advanced Materials, 2011. 23(13): p. 1514-1518.

18. Lee, S., et al., Flexible organic solar cells composed of P3HT:PCBM using chemically doped graphene electrodes. Nanotechnology, 2012. 23(34).

19. Hsu, C.-L., et al., Layer-by-Layer Graphene/TCNQ Stacked Films as Conducting Anodes for Organic Solar Cells. Acs Nano, 2012. 6(6): p. 5031-5039.

20. Park, H., et al., Interface engineering of graphene for universal applications as both anode and cathode in organic photovoltaics. Scientific Reports, 2013. 3.

21. Liu, Z., J. Li, and F. Yan, Package-Free Flexible Organic Solar Cells with Graphene top Electrodes. Advanced Materials, 2013. 25(31): p. 4296-4301.

22. Kim, H., et al., Organic solar cells using CVD-grown graphene electrodes. Nanotechnology, 2014. 25(1).

23. Lee, B.H., et al., Graphene-Conducting Polymer Hybrid Transparent Electrodes for Efficient Organic Optoelectronic Devices. Advanced Functional Materials, 2014. 24(13): p. 1847-1856.

24. Bae, S., et al., Roll-to-roll production of 30-inch graphene films for transparent electrodes. Nature Nanotechnology, 2010. 5(8): p. 574-578.

25. Kang, J., et al., Graphene transfer: key for applications. Nanoscale, 2012. 4(18): p. $5527-5537$.

26. Canestraro, C.D., Dispositivos fotovoltaicos orgânicos: estudos de camadas ativas e eletrodos. Paraná, Tese de Doutorado - Universidade Federal do Paraná Programa de Pós-Graduação em Engenharia e Ciência dos Materiais, 2010. 
27. Marchiori, C.F.N., Modificações em heterojunções doador/aceitador para o aumento da eficiência de dispositivos fotovoltaicos orgânicos. Paraná, Tese de Doutorado - Universidade Federal do Paraná - Programa de Pós-Graduação em Física, 2016.

28. Campbell, A.J., D.D.C. Bradley, and D.G. Lidzey, Space-charge limited conduction with traps in poly(phenylene vinylene) light emitting diodes. Journal of Applied Physics, 1997. 82(12): p. 6326-6342.

29. Menezes, L.C.W., Semicondutores Orgânicos Processados por Meio de Solventes Ecológicos e Halogenados com Aplicação Fotovoltaica. Paraná, Tese de Doutorado - Universidade Federal do Paraná - Programa de Pós-Graduação em Física, 2018.

30. Bonaccorso, F., et al., Graphene photonics and optoelectronics. Nature Photonics, 2010. 4(9): p. 611-622.

31. Li, G., R. Zhu, and Y. Yang, Polymer solar cells. Nature Photonics, 2012. 6: p. 153.

32. Hoppe, H. and N.S. Sariciftci, Morphology of polymer/fullerene bulk heterojunction solar cells. Journal of Materials Chemistry, 2006. 16(1): p. 45-61.

33. Choy, W.C.H., Organic Solar Cells: Materials and Device Physics. 2012: Springer London.

34. Yamamoto, N.A.D., Células Solares Orgânicas Baseadas nas Estruturas Heterojunção em Bicamada e Heterojunção de Volume. Paraná, Tese de Doutorado - Universidade Federal do Paraná - Programa de Pós-Graduação em Física, 2014.

35. Qi, B. and J. Wang, Open-circuit voltage in organic solar cells. Journal of Materials Chemistry, 2012. 22(46): p. 24315-24325.

36. Al-Alwani, M.A.M., et al., Dye-sensitised solar cells: Development, structure, operation principles, electron kinetics, characterisation, synthesis materials and natural photosensitisers. Renewable and Sustainable Energy Reviews, 2016. 65: p. 183-213.

37. Coakley, K.M.M., M. D. , Conjugated Polymer Photovoltaic Cells. Chemistry of materials, 2004. 16(23): p. 4533-4542.

38. Wöhrle, D. and D. Meissner, Organic Solar Cells. Advanced Materials, 1991. 3(3): p. 129-138. 
39. Choy, W.C.H., Organic solar cells materials and device physics. 2013, London: Springer.

40. Sariciftci, N.S., et al., Photoinduced electron transfer from a conducting polymer to buckminsterfullerene. Science, 1992. 258(5087): p. 1474-6.

41. Lin, C.-F., et al., High Photoelectric Conversion Efficiency of Metal Phthalocyanine/Fullerene Heterojunction Photovoltaic Device. International Journal of Molecular Sciences, 2011. 12(1): p. 476.

42. Nelson, J., Organic photovoltaic films. Current Opinion in Solid State and Materials Science, 2002. 6(1): p. 87-95.

43. Peumans, P., V. Bulović, and S.R. Forrest, Efficient photon harvesting at high optical intensities in ultrathin organic double-heterostructure photovoltaic diodes. Applied Physics Letters, 2000. 76(19): p. 2650-2652.

44. Chan, M.Y., et al., Doping-induced efficiency enhancement in organic photovoltaic devices. Applied Physics Letters, 2007. 90(2): p. 023504.

45. Li, X., et al., Fullerene-Free Organic Solar Cells with Efficiency Over 12\% Based on EDTA-ZnO Hybrid Cathode Interlayer. Chemistry of Materials, 2017. 29(10): p. $4176-4180$.

46. Liu, Z., et al., The Application of Highly Doped Single-Layer Graphene as the Top Electrodes of Semitransparent Organic Solar Cells. Acs Nano, 2012. 6(1): p. 810-818.

47. Pang, S.P., et al., Graphene as Transparent Electrode Material for Organic Electronics. Advanced Materials, 2011. 23(25): p. 2779-2795.

48. Kim, K.K., et al., Enhancing the conductivity of transparent graphene films via doping. Nanotechnology, 2010. 21(28).

49. Yazdi, G., T. Iakimov, and R. Yakimova, Epitaxial Graphene on SiC: A Review of Growth and Characterization. Crystals, 2016. 6(5): p. 53.

50. Castro Neto, A.H., et al., The electronic properties of graphene. Reviews of Modern Physics, 2009. 81(1): p. 109-162.

51. Nair, R.R., et al., Fine structure constant defines visual transparency of graphene. Science, 2008. 320(5881): p. 1308-1308.

52. Dresselhaus, M.S., A. Jorio, and R.Saito, Characterizing Graphene, Graphite, and Carbon Nanotubes by Raman Spectroscopy. Annual Review of Condensed Matter Physics, 2010. 1(1): p. 89-108. 
53. Malard, L.M., et al., Raman spectroscopy in graphene. Physics Reports-Review Section of Physics Letters, 2009. 473(5-6): p. 51-87.

54. Jorio, A., et al., Front Matter, in Raman Spectroscopy in Graphene Related Systems. 2011, Wiley-VCH Verlag GmbH \& Co. KGaA. p. I-XIV.

55. Reina, A., et al., Large Area, Few-Layer Graphene Films on Arbitrary Substrates by Chemical Vapor Deposition. Nano Letters, 2009. 9(1): p. 30-35.

56. Novoselov, K.S., et al., Electric field effect in atomically thin carbon films. Science, 2004. 306(5696): p. 666-669.

57. Dreyer, D.R., et al., The chemistry of graphene oxide. Chemical Society Reviews, 2010. 39(1): p. 228-240.

58. Colombo, L., R.M. Wallace, and R.S. Ruoff, Graphene Growth and Device Integration. Proceedings of the Ieee, 2013. 101(7): p. 1536-1556.

59. Stoldt, C.R., C. Carraro, and R. Maboudian, Deuterium etching of the Si-rich SiC(0001) (3 x 3) surface reconstruction. Surface Science, 2000. 466(1-3): p. 6672.

60. Rana, K., J. Singh, and J.H. Ahn, A graphene-based transparent electrode for use in flexible optoelectronic devices. Journal of Materials Chemistry C, 2014. 2(15): p. $2646-2656$.

61. Li, X.S., et al., eds. Large-Area Synthesis of High-Quality and Uniform Graphene Films on Copper Foils. Science. Vol. 324. 2009. 1312-1314.

62. Kim, K.S., et al., Large-scale pattern growth of graphene films for stretchable transparent electrodes. Nature, 2009. 457(7230): p. 706-710.

63. Calil, V.L., Desenvolvimento e caracterização de substratos compósitos flexíveis para aplicação em dispositivos orgânicos. Rio de Janeiro, Tese de Doutorado Pontíficia Universidade Católica do Rio de Janeiro - Programa de Pós graduação em Física, 2014.

64. Liao, C., et al., Flexible Organic Electronics in Biology: Materials and Devices. Advanced Materials, 2015. 27(46): p. 7493-7527.

65. Kaltenbrunner, M., et al., Ultrathin and lightweight organic solar cells with high flexibility. Nature Communications, 2012. 3: p. 770.

66. Araujo, J.R., et al., Chapter 8 - Characterization of Polyaniline-Based Blends, Composites, and Nanocomposites A2 - Visakh, P.M, in Polyaniline Blends, Composites, and Nanocomposites, C.D. Pina and E. Falletta, Editors. 2018, Elsevier. p. 209-233. 
67. Barra, G.M.O.C., .J. S.; Bertolino, J. R.; Soldi, V.; Nunes Pires, A. T. , Maleic Anhydride Grafting on EPDM: Qualitative and Quantitative Determination. Journal of the Brazilian Chemical Society, 1999. 10(1): p. 31 - 34.

68. Ravishankar, P.S., TREATISE ON EPDM. Rubber Chemistry and Technology, 2012. 85(3): p. 327-349.

69. Araujo, J.R., Preparação de biomicrofibras vegetais condutoras e aplicação como agente antiestático em poliamida-6. Campinas, Tese de Doutorado Universidade Estadual de Campinas - Instituto de Química, 2012.

70. Wang, Z., et al., Flexible ITO-Free Organic Solar Cells Based on $\mathrm{MoO}_{3} / \mathrm{Ag}$ Anodes. IEEE Photonics Journal, 2015. 7(1): p. 1-9.

71. Zhao, B., et al., Flexible polymer solar cells with power conversion efficiency of 8.7\%. Journal of Materials Chemistry C, 2014. 2(26): p. 5077-5082.

72. Pinto, E.R.P., et al., Transparent composites prepared from bacterial cellulose and castor oil based polyurethane as substrates for flexible OLEDs. Journal of Materials Chemistry C, 2015. 3(44): p. 11581-11588.

73. Legnani, C., et al., Bacterial cellulose membrane as flexible substrate for organic light emitting devices. Thin Solid Films, 2008. 517(3): p. 1016-1020.

74. Yamamoto, N.A.D., et al., Modification of PEDOT:PSS anode buffer layer with HFA for flexible polymer solar cells. Chemical Physics Letters, 2013. 572: p. 7377.

75. Calil, V.L., et al., Transparent thermally stable poly(etherimide) film as flexible substrate for OLEDs. Thin Solid Films, 2009. 518(5): p. 1419-1423.

76. Baker, M.I., et al., A review of polyvinyl alcohol and its uses in cartilage and orthopedic applications. Journal of Biomedical Materials Research Part B: Applied Biomaterials, 2012. 100B(5): p. 1451-1457.

77. Chen, K.Y., et al., Synthesis and characterization of poly(vinyl alcohol) membranes with quaternary ammonium groups for wound dressing. $\mathrm{J}$ Biomater Sci Polym Ed, 2010. 21(4): p. 429-43.

78. Shi, Z., et al., Utilization of bacterial cellulose in food. Food Hydrocolloids, 2014. 35: p. 539-545.

79. Achete, C.A.L., C.; Quirino, W. G.; Cremona, M.; Ribeiro, S. J. L.; Barud, H. S.; Messaddeq, Y., Dispositivo orgânico emissor de luz biocompativel e processo para sua produção. PI0903286-0A2. 2010., 2009.

80. Williams, C., Electronics World. 2007. 10: p. 40 - 41. 
81. Moseley, H., et al., Ambulatory photodynamic therapy: a new concept in delivering photodynamic therapy. Br J Dermatol, 2006. 154(4): p. 747-50.

82. Kim, D.Y., G. Sarasqueta, and F. So, SnPc:C60 bulk heterojunction organic photovoltaic cells with MoO3 interlayer. Solar Energy Materials and Solar Cells, 2009. 93(8): p. 1452-1456.

83. Yang, F., R.R. Lunt, and S.R. Forrest, Simultaneous heterojunction organic solar cells with broad spectral sensitivity. Applied Physics Letters, 2008. 92(5): p. 053310 .

84. Kroto, H.W., et al., C60: Buckminsterfullerene. Nature, 1985. 318: p. 162.

85. Colle, M., R.E. Dinnebier, and W. Brutting, The structure of the blue luminescent [small delta]-phase of tris(8-hydroxyquinoline)aluminium(iii) (Alq3). Chemical Communications, 2002(23): p. 2908-2909.

86. Anthopoulos, T.D., et al., Highly efficient single-layer dendrimer light-emitting diodes with balanced charge transport. Applied Physics Letters, 2003. 82(26): p. 4824-4826.

87. Wang, J., et al., High efficiency green phosphorescent organic light-emitting diodes with a low roll-off at high brightness. Organic Electronics, 2013. 14(11): p. 2854-2858.

88. Nair, R.R., et al., Fine structure constant defines visual transparency of graphene. Science, 2008. 320(5881): p. 1308.

89. Gadelmawla, E.S., et al., Roughness parameters. Journal of Materials Processing Technology, 2002. 123(1): p. 133-145.

90. Malard, L.M., et al., Group-theory analysis of electrons and phonons in N-layer graphene systems. Physical Review B, 2009. 79(12).

91. Malard, L.M., et al., Probing the electronic structure of bilayer graphene by Raman scattering. Physical Review B, 2007. 76(20).

92. Park, J.S., et al., $G{ }^{\prime}$ band Raman spectra of single, double and triple layer graphene. Carbon, 2009. 47(5): p. 1303-1310.

93. Das, A., et al., Monitoring dopants by Raman scattering in an electrochemically top-gated graphene transistor. Nature Nanotechnology, 2008. 3(4): p. 210-215.

94. Berciaud, S., et al., Probing the Intrinsic Properties of Exfoliated Graphene: Raman Spectroscopy of Free-Standing Monolayers. Nano Letters, 2009. 9(1): p. 346-352. 
95. Jung, N., et al., Charge Transfer Chemical Doping of Few Layer Graphenes: Charge Distribution and Band Gap Formation. Nano Letters, 2009. 9(12): p. 4133-4137.

96. An, J., et al., Polyaniline-Grafted Graphene Hybrid with Amide Groups and Its Use in Supercapacitors. Journal of Physical Chemistry C, 2012. 116(37): p. 19699-19708.

97. Gunasekaran, S., R.K. Natarajan, and A. Kala, FTIR spectra and mechanical strength analysis of some selected rubber derivatives. Spectrochimica Acta Part a-Molecular and Biomolecular Spectroscopy, 2007. 68(2): p. 323-330.

98. Allahbakhsh, A. and S. Mazinani, Influences of sodium dodecyl sulfate on vulcanization kinetics and mechanical performance of EPDM/graphene oxide nanocomposites. RSC Advances, 2015. 5(58): p. 46694-46704.

99. Socrates, G., Infrared and Raman Characteristic Group Frequencies: Tables and Charts. 2001: Wiley.

100. Araujo, J.R., et al., Elastomer Composite Based on EPDM Reinforced with Polyaniline Coated Curaua Fibers Prepared by Mechanical Mixing. Journal of Applied Polymer Science, 2014. 131(7).

101. Elnaggar, E.M., et al., Comparative study on doping of polyaniline with graphene and multi-walled carbon nanotubes. Journal of Nanostructure in Chemistry, 2017. 7(1): p. 75-83.

102. Wei, D., et al., Synthesis of N-Doped Graphene by Chemical Vapor Deposition and Its Electrical Properties. Nano Letters, 2009. 9(5): p. 1752-1758.

103. Caglar, Y., et al., Electrical characterization of ZnO/organic semiconductor diode. Journal of Optoelectronics and Advanced Materials, 2008. 10(10): p. 25842587.

104. Servaites, J.D., M.A. Ratner, and T.J. Marks, Organic solar cells: A new look at traditional models. Energy \& Environmental Science, 2011. 4(11): p. 4410-4422.

105. Garcia-Belmonte, G., et al., Perimeter leakage current in polymer light emitting diodes. Current Applied Physics, 2009. 9(2): p. 414-416.

106. Blakesley, J.C. and D. Neher, Relationship between energetic disorder and opencircuit voltage in bulk heterojunction organic solar cells. Physical Review B, 2011. 84(7): p. 075210.

107. Sandberg, O.J., M. Nyman, and R. Österbacka, Effect of Contacts in Organic Bulk Heterojunction Solar Cells. Physical Review Applied, 2014. 1(2): p. 024003. 
108. Finck, B.Y. and B.J. Schwartz, Understanding the origin of the S-curve in conjugated polymer/fullerene photovoltaics from drift-diffusion simulations. Applied Physics Letters, 2013. 103(5): p. 053306.

109. Callister, W.D., Ciência e engenharia de materiais: uma introdução. 2013: LTC. 